\title{
GROUND-WATER CONDITIONS IN GEORGIA, 1989
}

By Michael F. Peck, Charles N. Joiner, John S. Clarke, and Alan M. Cressler

U.S. GEOLOGICAL SURVEY

OPEN-FILE REPORT 90-706

Prepared in cooperation with

GEORGIA DEPARTMENT OF NATURAL RESOURCES

ENVIRONMENTAL PROTECTION DIVISION

GEORGIA GEOLOGIC SURVEY

ALBANY WATER, GAS, AND LIGHT COMMISSION

CITY OF BRUNSWICK

GLYNN COUNTY

SAVANNAH-CHATHAM COUNTY METROPOLITAN PLANNING COMMISSION CITY OF VALDOSTA

Doraville, Georgia 


\title{
U.S. DEPARTMENT OF INTERIOR
}

\section{MANUEL LUJAN, JR., Secretary}

\section{U.S. GEOLOGICAL SURVEY}

\author{
Dallas L. Peck, Director
}

For additional information write to:

District Chief

U.S. Geological Survey

6481-B Peachtree Industrial Blvd.

Doraville, Georgia 30360
Copies of this report may be purchased from:

U.S. Geological Survey

Books and Open-File Reports

Federal Center, Bldg. 810

Denver, Colorado 80225 


\title{
CONTENTS
}

\author{
Abstract 1 \\ Introduction 1 \\ Purpose and scope 2 \\ Well-numbering system 2 \\ Ground-water resources 2 \\ Precipitation 5 \\ Ground-water levels 7 \\ Surficial aquifers 21 \\ North Georgia area 21 \\ Southwest area 21 \\ Coastal area \\ Upper Brunswick aquifer 30 \\ Floridan aquifer system $\mathbf{3 0}$ \\ Upper Floridan aquifer $\mathbf{3 0}$ \\ Southwest area 37 \\ South-central area 37 \\ East-central area 51 \\ Coastal area 51 \\ Savannah area 51 \\ Jesup-Riceboro area 61 \\ Kings Bay-Okefenokee Swamp area 61 \\ Brunswick area 61 \\ Lower Floridan aquifer $\mathbf{7 2}$ \\ Brunswick area 72 \\ Claiborne aquifer $\mathbf{7 2}$ \\ Clayton aquifer 72 \\ Cretaceous aquifer system 97 \\ Providence aquifer 97 \\ Dublin, Midville, and Dublin-Midville aquifer systems 97 \\ Paleozoic rock aquifers 109 \\ Crystalline rock aquifers 109 \\ Chloride concentrations in the Floridan aquifer system 117 \\ Savannah area 117 \\ Brunswick area 117 \\ Selected references $\mathbf{1 2 4}$
}




\section{ILLUSTRATIONS}

Figure 1. Map showing areas of utilization of major aquifers and block diagram showing major aquifers and physiographic provinces of Georgia 3

2. Map showing locations of precipitation-monitoring stations and average annual precipitation in Georgia, 1941-70 6

Figures 3.-12. Graphs showing precipitation departure from normal for National Weather Service station:

3. Columbus Weather Service Office, Airport, Muscogee County 8

4. Rome, Floyd County 9

5. Savannah Weather Service Office, Airport, Chatham County 10

6. Cleveland, White County 11

7. Athens Weather Service Office, Airport, Clarke County 12

8. Albany 3 Southeast, Dougherty County 13

9. Clayton 1 South-southwest, Rabun County 14

10. Augusta Weather Service Office, Airport, Richmond County 15

11. Atlanta Weather Service Office, Airport, Fulton County 16

12. Macon Weather Service Office, Airport, Bibb County 17

Figure 13. Map showing locations of observation wells for which hydrographs are included in this report 18

14. Map showing locations of observation wells completed in the surficial aquifers 22

Figures 15.-22. Hydrographs showing the water level in observation well:

15. 11AA01, Spalding County 23

16. $13 \mathrm{M} 007$, Worth County 24

17. 07H003, Miller County 25

18. 35P094, Chatham County 26

19. 37P116, Chatham County 27

20. 32R003, Bulloch County 28

21. $34 \mathrm{H} 438$, Glynn County 29

22. 32L017, Wayne County 31

Figure 23. Map showing locations of observation wells completed in the upper Brunswick aquifer 32

Figures 24.-26. Hydrographs showing the water level in observation well:

24. 31U009, Bulloch County 33

25. 32L016, Wayne County 34

26. $34 \mathrm{H} 437$, Glynn County 35

Figure 27. Map showing subareas and locations of observation wells completed in the Upper Floridan aquifer 36

28. Map showing water levels and locations of observation wells completed in the Upper Floridan aquifer in the Albany area, November 198938

Figures 29.-43. Hydrographs showing the water level in observation well:

29. 09F520, Decatur County 39

30. 08G001, Miller County 40

31. 06F001, Seminole County 41

32. 13L012, Dougherty County 42

33. 10G313, Mitchell County 43

34. 13L003, Dougherty County 44

35. 13J004, Mitchell County 45

36. 15L020, Worth County 46

37. 18K049, Tift County 47

38. $18 \mathrm{H} 016$, Cook County 48

39. 19E009, Lowndes County 49

40. 19F039, Lowndes County 50

41. 21T001, Laurens County 52

42. 25Q001, Montgomery County $\mathbf{5 3}$

43. 26R001, Toombs County 54 


\section{ILLUSTRATIONS--Continued}

Figure 44. Map showing locations of observation wells coinpleted in the Upper Floridan aquifer in the coastal area $\mathbf{5 5}$

Figures 45.-59. Hydrographs showing the water level in observation well:

45. 36Q008, Chatham County 56

46. 36Q020, Chatham County 57

47. 38Q002, Chatham County 58

48. 39Q003, Chatham County 59

49. 32R002, Bulloch County 60

50. 30L003, Wayne County 62

51. 32L015, Wayne County 63

52. 33M004, Long County 64

53. 34M054, Liberty County 65

54. 34N089, Liberty County 66

55. 35M013, McIntosh County 67

56. 33E027, Camden County 68

57. 27E004, Charlton County 69

58. 33H127, Glynn County 70

59. 33H133, Glynn County 71

Figure 60. Map showing locations of observation wells completed in the Lower Floridan aquifer 73

Figures 61.-62. Hydrographs showing the water level in observation well:

61. 34H391, Glynn County 74

62. 33J044, Glynn County 75

Figure 63. Map showing water levels and locations of observation wells completed in the Claiborne aquifer, November 198976

Figures 64.-74. Hydrographs showing the water level in observation well:

64. 11L001, Dougherty County 77

65. 12L019, Dougherty County 78

66. 06K010, Early County 79

67. 09G001, Decatur County 80

68. 09M009, Randolph County $\mathbf{8 1}$

69. 14P015, Crisp County 82

70. 15R007, Dooly County 83

71. 13L011, Dougherty County 84

72. 11K002, Dougherty County 85

73. 11P015, Lee County 86

74. 13M005, Worth County 87

Figure 75. Map showing water levels and locations of observation wells completed in the Clayton aquifer, Noveunber 198988

Figures 76.-83. Hydrographs showing the water level in observation well:

76. 14P014, Crisp County 89

77. 07 N001, Randolph County 90

78. 09M007, Randolph County 91

79. 09N001, Terrell County 92

80. 11L002, Dougherty County 93

81. 13L002, Dougherty County 94

82. $06 \mathrm{~K} 009$, Early County 95

83. 11K005, Dougherty County 96

Figure 84. Map showing locations of observation wells completed in the Cretaceous aquifer system 98 


\section{ILLUSTRATIONS--Continued}

Figures 85.-91. Hydrographs showing the water level in observation well:

85. 06S001, Chattahoochee County 99

86. 12L021, Dougherty County 100

87. 18U001, Twiggs County 101

88. 18T001, Pulaski County 102

89. 21U004, Laurens County 103

90. 24V001, Johnson County 104

91. 28X001, Burke County 105

Figure 92. Map showing water levels and locations of observation wells completed in the Dublin-Midville aquifer system, November 1989106

Figures 93.-94. Hydrographs showing the water level in observation well:

93. 30AA04, Richmond County 107

94. 23X027, Washington County 108

Figure 95. Map showing location of observation well completed in the Paleozoic rock aquifers 110

96. Hydrographs showing the water level in observation well 03PP01, Walker County 111

97. Map showing locations of observation wells completed in the crystalline rock aquifers $\mathbf{1 1 2}$

Figures 98.-101. Hydrographs showing the water level in observation well:

98. 10DD02, Fulton County 113

99. 11FF04, DeKalb County 114

100. 19HH12, Madison County 115

101. 21BB04, Greene County 116

Figure 102. Map showing locations of chloride-monitoring wells completed in the Floridan aquifer system in the Savannah area 118

103. Graphs showing chloride concentrations in the Upper and Lower Floridan aquifers in the Savannah area 119

104. Map showing chloride concentrations and locations of chloride-monitoring wells in the upper water-bearing zone of the Upper Floridan aquifer in the Brunswick area, October 1989120

105. Graphs showing chloride concentrations in the Floridan aquifer system in the Bay Street area of Brunswick 121

106. Graphs showing chloride concentrations in the in the Floridan aquifer system in the north Brunswick area 122

\section{TABLES}

Table 1. Aquifer and well characteristics in Georgia 4

2. Observation wells for which water-level hydrographs are included in this report $\mathbf{1 9}$ 


\section{FACTORS FOR CONVERTING INCH-POUND UNITS \\ TO INTERNATIONAL SYSTEM (SI) UNITS}

Multiply inch-pound units

foot (ft)

mile (mi)

gallon per minute

(gal/min)

million gallons per day

(Mgal/d)

million gallons per day

(Mgal/d)

parts per million

(ppm) by

to obtain metric units

Length

2.540

0.3048

1.609

centimeters $(\mathrm{cm})$

meter (m)

kilometer $(\mathrm{km})$

Volumetric rate

0.06308

liter per second

$(\mathrm{L} / \mathrm{s})$

0.04381

cubic meter per second $\left(\mathrm{m}^{3} / \mathrm{s}\right)$

43.81

liter per second

$(\mathrm{L} / \mathrm{s})$

\section{Concentration}

1

milligram per liter

(mg/L)

Sea level.--In this report "sea level" refers to the National Geodetic Vertical Datum of 1929 (NGVD of 1929)--a geodetic datum derived from a general adjustment of the first-order level nets of both the United States and Canada, formerly called Sea Level Datum of 1929. 


\title{
GROUND-WATER CONDITIONS IN GEORGIA, 1989
}

\author{
By \\ Michael F. Peck, Charles N. Joiner, John S. Clarke, and Alan M. Cressler
}

\begin{abstract}
Ground-water conditions in Georgia during 1989, and the 10-year period, 1980-89, were evaluated using data from ground-water-level and ground-water-quality monitoring networks. These data include continuous water-level records from 76 wells, periodic water-level measurements from an additional 589 wells, precipitation records from 10 National Weather Service stations, and chloride analyses from 104 wells during 1989.

Annual mean ground-water levels in Georgia in 1989 ranged from 4.1 feet lower to 10.8 feet higher than those for 1988. With the exception of the coastal area, precipitation was above normal during 1989 . Of the 76 continuous-record wells included in this report, 39 had mean water levels that were higher in 1989 than in 1988. Thirty-seven wells had mean water levels that were lower in 1989 than in 1988, 21 of which were in the coastal area. Record low water levels were measured in nine wells tapping the upper Brunswick aquifer, Floridan aquifer system, the Clayton aquifer, and the Cretaceous aquifer system. These record lows were from 0.1 foot to 1.1 feet lower than the previous record lows. The overall water-level trend during 1980-89 was downward in 50 of the 76 wells due to below-normal precipitation and increased pumping.

Periodic water sampling and analysis in the coastal area indicates that chloride concentrations in the Upper Floridan aquifer generally have decreased or remained stable during 1980-89. However, chloride concentrations have increased $\mathbf{4 0}$ to 200 milligrams per liter in the northern part of Brunswick over the same period. Chloride concentrations in the Lower Floridan aquifer during 1980-89 remained about the same in the Savannah area, but increased 200 to 925 milligrams per liter in the Bay Street area of Brunswick.
\end{abstract}

\section{INTRODUCTION}

Monitoring ground-water levels and quality is essential to water-resources management. Groundwater levels and quality have been monitored in Georgia for about 100 years. In the early years, water-level data were used in areal reconnaissance studies to show water-level trends. These data had limited value for resource-management purposes because of the large amount of time between collection and publication of the data.

As part of the cooperative ground-water investigations undertaken by the U.S. Geological Survey and the State of Georgia, a statewide water-level-measurement program was begun in 1938. Initially, this program consisted of an observation-well network in the coastal area of Georgia that provided data concerning changes in ground-water storage and quality. Additional wells were added in areas where changes in water levels and water quality could forewarn potential water-resources problems. About 1,200 water-level measurements were made in Georgia during 1989. Water-level measurements were made in 589 wells, and levels were continuously monitored in an additional 128 network wells (76 of which are included in this report), and 13 project wells. During 1989, water samples were collected from 104 wells and analyzed to monitor chloride concentrations in the Savannah and Brunswick areas. 


\section{Purpose and Scope}

This report continues a series of annual publications that present both ground-water-level and groundwater-quality data for Georgia. Formerly titled "Ground-water Data for Georgia", the series is herein renamed "Ground-water Conditions in Georgia" to more accurately reflect its content.

Hydrographs for 76 wells, precipitation graphs for 10 National Weather Service stations, and waterlevel maps of the Upper Floridan; Claiborne, and Clayton aquifers, and the Dublin-Midville aquifer system have been selected to illustrate the effects that changes in recharge and discharge have had on the various aquifers in the State. Graphs of chloride concentrations for 13 wells in the coastal area and a chloride concentration map for the Upper Floridan aquifer in the Brunswick area have been included to show the distribution and changes in chloride concentration during 1980-89.

\section{Well Numbering System}

Wells in this report are numbered according to a system based on the U.S. Geological Survey index to topographic maps of Georgia. Each 7 1/2-minute topographic quadrangle in the State has been given a six-digit number and letter designation beginning at the southwestern corner of the State. Numbers increase sequentially eastward and letters advance alphabetically northward. Quadrangles in the northern part of the State are designated by double letters, with AA following $\mathrm{Z}$ and so forth. The letters "I", "O", "II", and "OO" are not used. Wells inventoried in each quadrangle are numbered consecutively, beginning with 01 . Thus, the fourth well scheduled in the 11AA quadrangle is designated 11AA04.

\section{Ground-Water Resources}

Differing geologic features and landforms of the physiographic provinces of Georgia cause substantial differences in ground-water conditions from one part of the State to another. These features affect the quantity and quality of the ground water throughout the State (fig. 1, table 1).

Surficial aquifers are present in each of the different physiographic provinces. These aquifers are usually unconfined, and are used for domestic and stock supplies in most areas of Georgia. In the Piedmont, Blue Ridge, and Valley and Ridge provinces, the surficial aquifers occur in the regolith, which consists of soil, saprolite, stream alluvium, colluvium, and other surficial deposits. In the Coastal Plain province, the surficial aquifers consist of intermixed layers of sand, clay, and limestone. In the coastal area, the surficial aquifers locally may be under semi-confined conditions.

The most productive aquifers in Georgia are in the Coastal Plain province in the southern part of the State. The Coastal Plain is underlain by alternating layers of sand, clay, and limestone that dip and thicken to the southeast. In the Coastal Plain, aquifers generally are confined, except near their northern limits where they crop out or are near land surface. The aquifers of the Coastal Plain include, in descending order, the upper Brunswick aquifer, the lower Brunswick aquifer, the Floridan aquifer system, the Claiborne aquifer, the Clayton aquifer, and the Cretaceous aquifer system (fig. 1, table 1). 

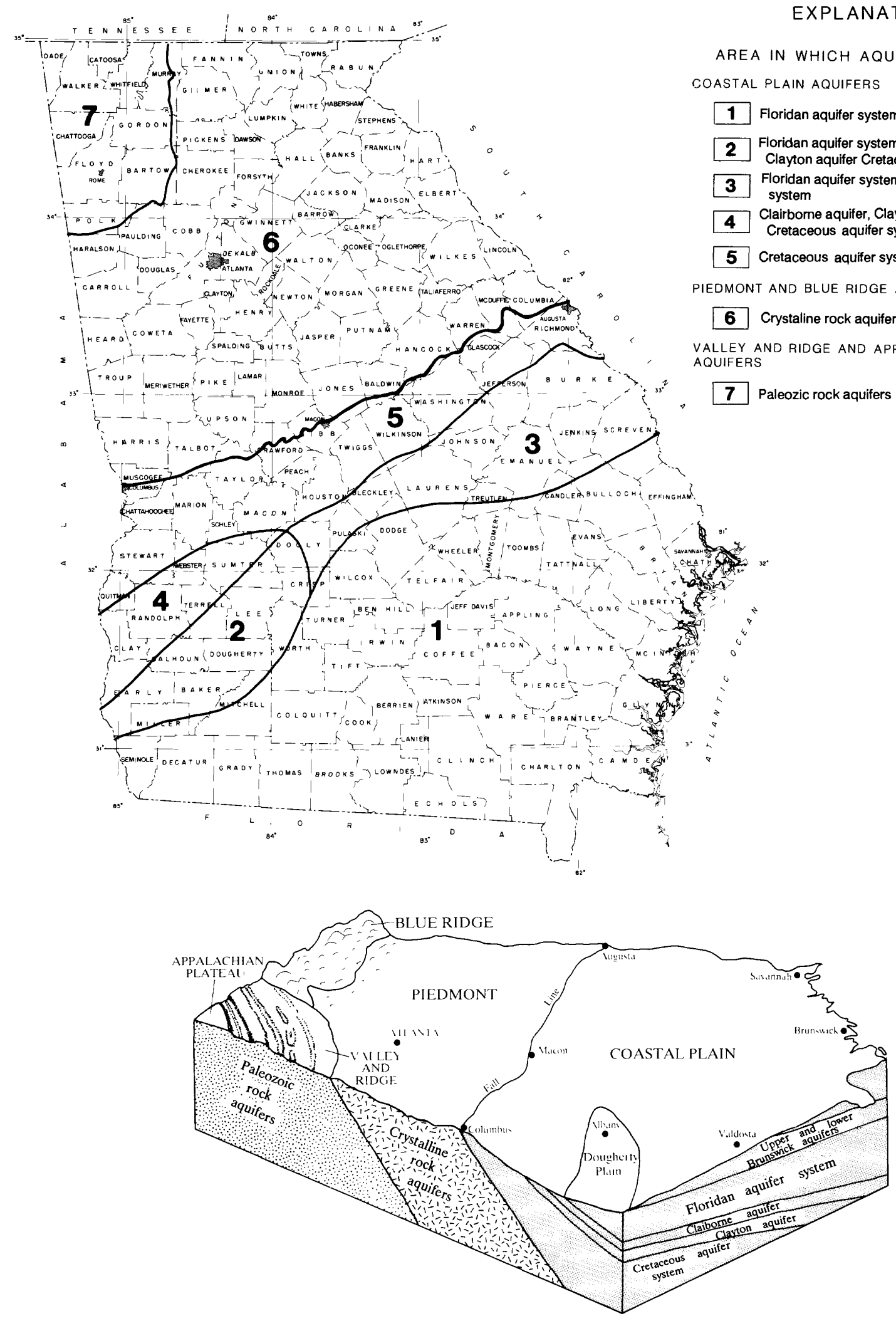

Figure 1.--Areas of utilization of major aquifers and block diagram showing major aquifers and physiographic provinces of Georgia. 
Table 1.--Aquifer and well characteristics in Georgia

[Modified from Clarke and Pierce, 1984; ft, feet; gal/min, gallons per minute]

\begin{tabular}{lccc}
\hline & \multicolumn{3}{c}{ Well characteristics } \\
\cline { 2 - 4 } & $\begin{array}{c}\text { Depth } \\
(\mathrm{ft})\end{array}$ & Yield (gal/min) & \\
$\begin{array}{c}\text { Aquifer name } \\
\text { and description }\end{array}$ & $\begin{array}{c}\text { Common } \\
\text { range }\end{array}$ & $\begin{array}{c}\text { Common } \\
\text { range }\end{array}$ & May \\
\hline
\end{tabular}

Upper Brunswick aquifer:

Phosphatic and dolomitic quartz sand. Generally confined.

\section{Lower Brunswick aquifer}

Phosphatic and dolomitic quartz sand. Generally

confined.

\section{Floridan aquifer system:}

Limestone, dolostone, and calcareous sand. Generally confined.

\section{5-200 10-15}

190-390

$15-30$

180

$40-900 \quad 1,000-5,000 \quad 11,000$
Claiborne aquifer: Sand and sandy limestone. Generally confined.

$20-450 \quad 150-600$

1,500

Clayton aquifer: Limestone and sand. Generally confined.
$40-800 \quad 250-600 \quad 2,150$
30

Not a major source of water in coastal Georgia, but considered a supplemental water supply to the Upper Floridan aquifer. Most wells are multiaquifer tapping both the Upper and Lower Brunswick aquifers and the Upper Floridan aquifer.
Supplies 50 percent of ground water in Georgia. The aquifer system is divided into the Upper and Lower Floridan aquifers. In the Brunswick area, the Upper Floridan aquifer includes two freshwater-bearing zones: the upper water-bearing zone and the lower waterbearing zone. The lower Floridan aquifer is not considered a major aquifer because of high chloride concentrations. In the Brunswick area, the Lower Floridan aquifer consists of the brackishwater zone, the deep freshwater zone, and the Fernandina permeable zone.

Major source of water in southwestern Georgia. Supplies industrial and municipal users at Dougherty, Crisp and Dooly Counties and provides irrigation water north of Dougherty Plain. In eastcentral Georgia, the Claiborne aquifer is part of the Gordon aquifer system.

Major source of water in southwestern Georgia. Supplies industrial and municipal users at Albany and provides irrigation water northwest of Albany. Water-level declines exceed $100 \mathrm{ft}$ at Albany. 
Table 1.--Aquifer and well characteristics in Georgia--Continued

[Modified from Clarke and Pierce, 1984; ft, feet; gal/min, gallons per minute]

\begin{tabular}{|c|c|c|c|c|}
\hline \multirow[b]{3}{*}{$\begin{array}{l}\text { Aquifer name } \\
\text { and description }\end{array}$} & \multicolumn{3}{|c|}{ Well characteristics } & \multirow[b]{3}{*}{ Remarks } \\
\hline & $\begin{array}{l}\text { Depth } \\
\text { (ft) }\end{array}$ & \multicolumn{2}{|c|}{ Yield (gal/min) } & \\
\hline & $\begin{array}{l}\text { Common } \\
\text { range }\end{array}$ & $\begin{array}{c}\text { Common } \\
\text { range }\end{array}$ & $\begin{array}{c}\text { May } \\
\text { exceed }\end{array}$ & \\
\hline $\begin{array}{l}\text { Cretaceous aquifer system: } \\
\text { Sand and gravel. Generally } \\
\text { confined. }\end{array}$ & $30-750$ & $50-1,200$ & 3,300 & $\begin{array}{l}\text { Major source of water in east-central } \\
\text { Georgia. Supplies water for kaolin } \\
\text { mining and processing. Includes } \\
\text { Providence aquifer in southwestern } \\
\text { Georgia and the Dublin and Midville } \\
\text { aquifer systems in east-central } \\
\text { Georgia. Water-level declines greater } \\
\text { than } 50 \mathrm{ft} \text { at kaolin mining centers and } \\
100 \mathrm{ft} \text { near Albany. }\end{array}$ \\
\hline $\begin{array}{l}\text { Paleozoic rock aquifers: } \\
\text { Sandstone, limestone, and } \\
\text { dolostone; storage is in } \\
\text { regolith and fractures and } \\
\text { solution openings in rock. } \\
\text { Generally unconfined. }\end{array}$ & $15-2,100$ & $1-50$ & 3,500 & $\begin{array}{l}\text { Not laterally extensive. Limestone and } \\
\text { dolostone aquifers most productive. } \\
\text { Springs in limestone and dolostome } \\
\text { aquifers discharge at rates of as much } \\
\text { as } 5,000 \mathrm{gal} / \mathrm{min} \text {. Sinkholes can form } \\
\text { in areas of intensive pumping. }\end{array}$ \\
\hline $\begin{array}{l}\text { Crystalline rock aquifers: } \\
\text { Granite, gneiss, schist, and } \\
\text { quartzite; storage is in } \\
\text { fractures in rock and in } \\
\text { regolith. Generally } \\
\text { unconfined. }\end{array}$ & $40-600$ & $1-25$ & 500 & Not laterally extensive. \\
\hline
\end{tabular}

\section{PRECIPITATION}

Recharge to the ground-water system in Georgia is derived almost entirely from precipitation. Based on records for 1941-70, annual precipitation averaged 50 in. (inches) statewide, and ranged from 44 in. in the east-central part to about 76 in. in the northeastern corner (fig. 2) (Carter and Stiles, 1983). Of the total annual precipitation, about 88 percent is discharged to streams or is lost to evapotranspiration, and about 12 percent enters the ground-water system as recharge (Carter and Stiles, 1983). 


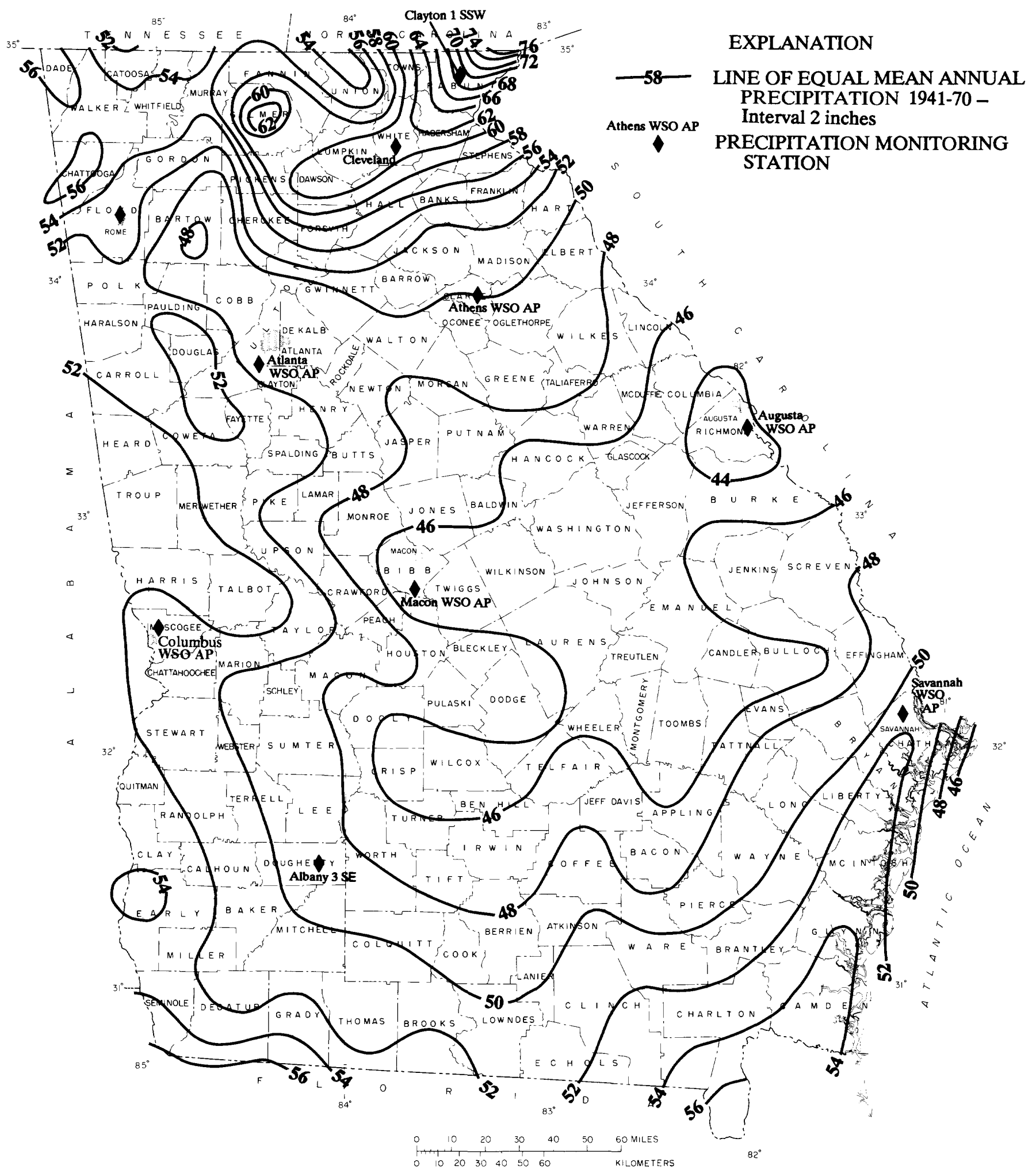

Figure 2.-- Locations of precipitation-monitoring stations and average annual precipitation in Georgia, 1941-70. Modified from Carter and Stiles (1983). 
Cumulative departure is a term used to describe the long-term surplus or deficit of precipitation over a designated period of time. It is derived by adding successive monthly values of precipitation departures from normal. For example, if precipitation in January was 2 in. above normal and in February was 1 in. below normal, the cumulative departure would be $(+2)+(-1)=+1$ in. Thus, the annual cumulative departure through December would represent the sum of all deficits or surpluses during the year. Similarly, the 10-yr cumulative departure at the end of December would represent the sum of all deficits or surpluses for the previous 120 months.

Monthly mean precipitation data furnished by the National Weather Service are shown graphically for 10 precipitation stations (figs. 3-12). For each station, monthly precipitation was compared to the 30-yr (195180) average (normal) for the station. The lower graph shows the cumulative departure from normal precipitation for the period 1980-89; the upper graph shows the monthly departure and cumulative departure for 1989.

Precipitation over most of Georgia was above normal during 1989. The cumulative departure of precipitation for 1989 at nine of the ten National Weather Service Stations ranged from 5.8 in. above normal at Columbus (fig. 3) to 21.4 in. above normal at Rome (fig. 4). At the Savannah station (fig. 5), precipitation was 2.8 in. below normal for the year. At the Columbus, Cleveland, Athens, Albany, Clayton, and Augusta stations (figs. 3, 6, 7, 8, 9, and 10), precipitation was substantially below normal from January through May, but generally was above normal from June through December. Precipitation at the Atlanta and Macon stations (figs. 11 and 12) generally was below normal from January through March, but was above normal for most of April through December. At the Savannah station (fig. 5), precipitation generally was below normal from January through August, and above normal from September through December. At the Rome station (fig. 4), precipitation generally was above normal for the entire year.

For the 10-yr period 1980-89, the cumulative departure of precipitation was below normal at seven of the 10 stations, and ranged from $10.6 \mathrm{in}$. below normal at the Macon station (fig. 12) to $77.2 \mathrm{in}$. below normal at the Clayton station (fig. 9). The 10-yr cumulative departure was above normal for 1980-89 at the Albany $(+19.7$ in.), Augusta (+4.5 in.), and Atlanta (+11.6 in.) stations (figs. 8, 10, and 11).

\section{GROUND-WATER LEVELS}

Fluctuations and long-term trends in water levels occur as a result of changes in recharge to and discharge from the aquifer. Recharge varies in response to precipitation, evapotranspiration, and surface-water infiltration into the aquifer. Discharge occurs as natural flow from the aquifer to streams and springs, as evapotranspiration from shallow water-table aquifers, and as withdrawal from wells.

Water-level fluctuations and trends were monitored in a network of 128 wells completed in the surficial and upper Brunswick aquifers, the Floridan aquifer system, the Claiborne and Clayton aquifers, the Cretaceous aquifer system, the Paleozoic rock aquifers, and the crystalline rock aquifers. Of the 128 network wells that were monitored continuously during 1989 , daily mean water levels are shown in hydrographs for 76 of the wells (fig. 13, table 2). Water-level fluctuations and trends in these 76 wells were considered to represent groundwater conditions throughout much of the State. For each well, daily-mean water levels are shown in hydrographs for 1989, and monthly-mean water levels are shown for the 10-yr period, 1980-89. A summary of monthly and annual water-level statistics is included with each hydrograph. In this report, a record water level refers to the lowest or highest daily-mean water level for the period of record in a particular well. Thus, any individual water-level measurement on a given day may be lower or higher than the record mentioned in the text, the minimum or maximum value in the statistics, or the daily-mean measurement shown on the hydrograph. 

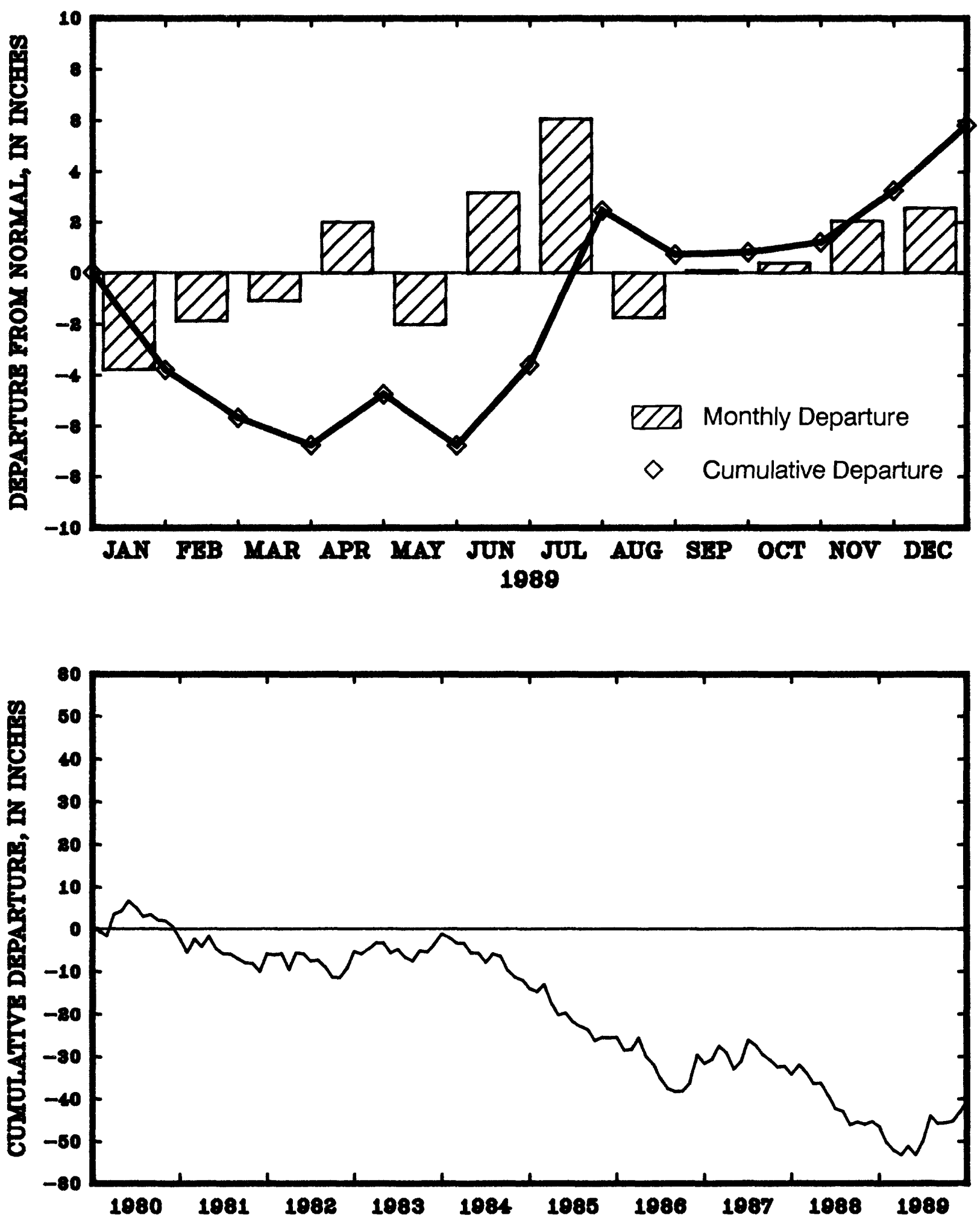

Figure 3.--Precipitation departure from normal for National Weather Service station at Columbus Weather Service Office, Airport, Muscogee County. 

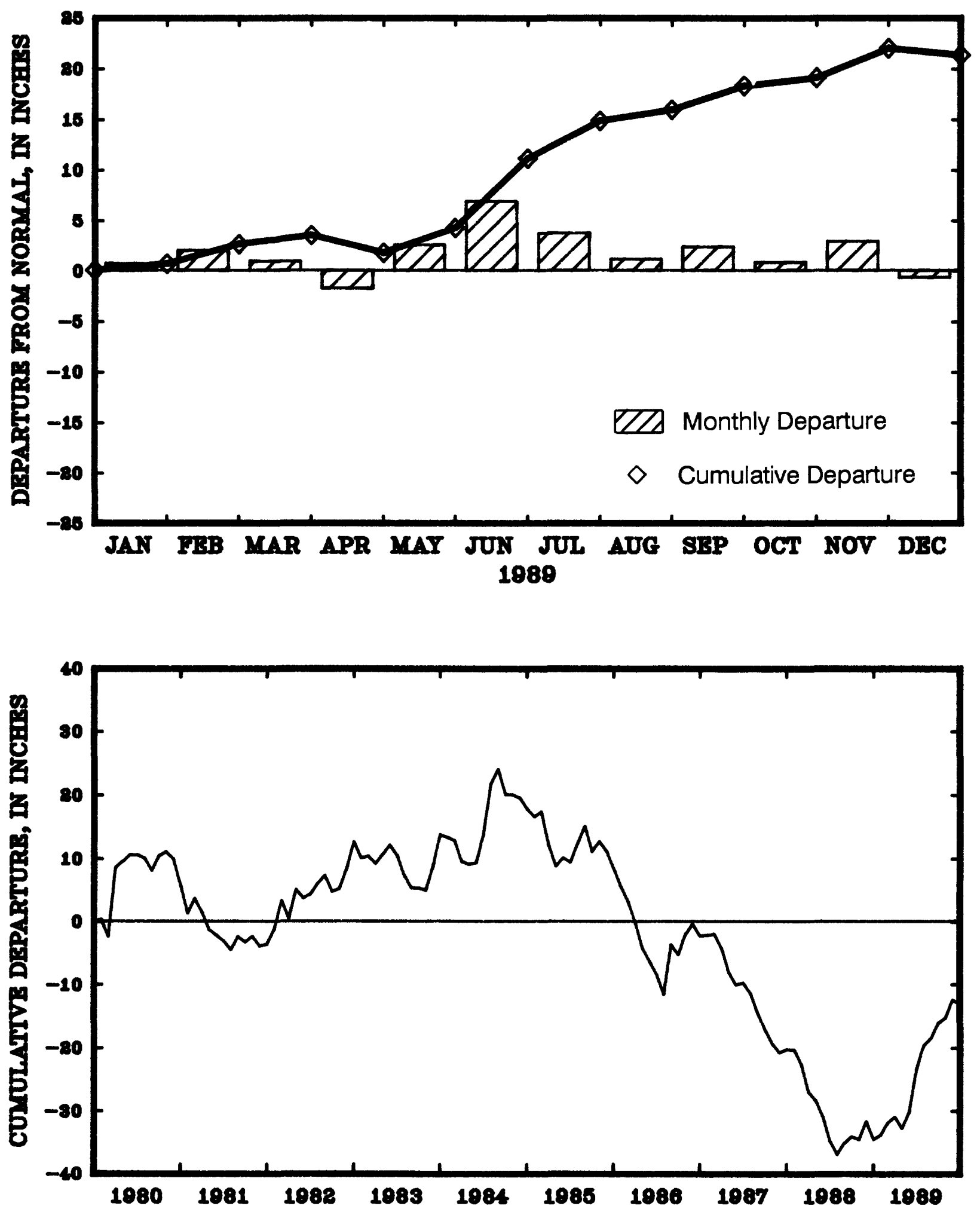

Figure 4.--Precipitation departure from normal for National Weather Service station at Rome, Floyd County. 

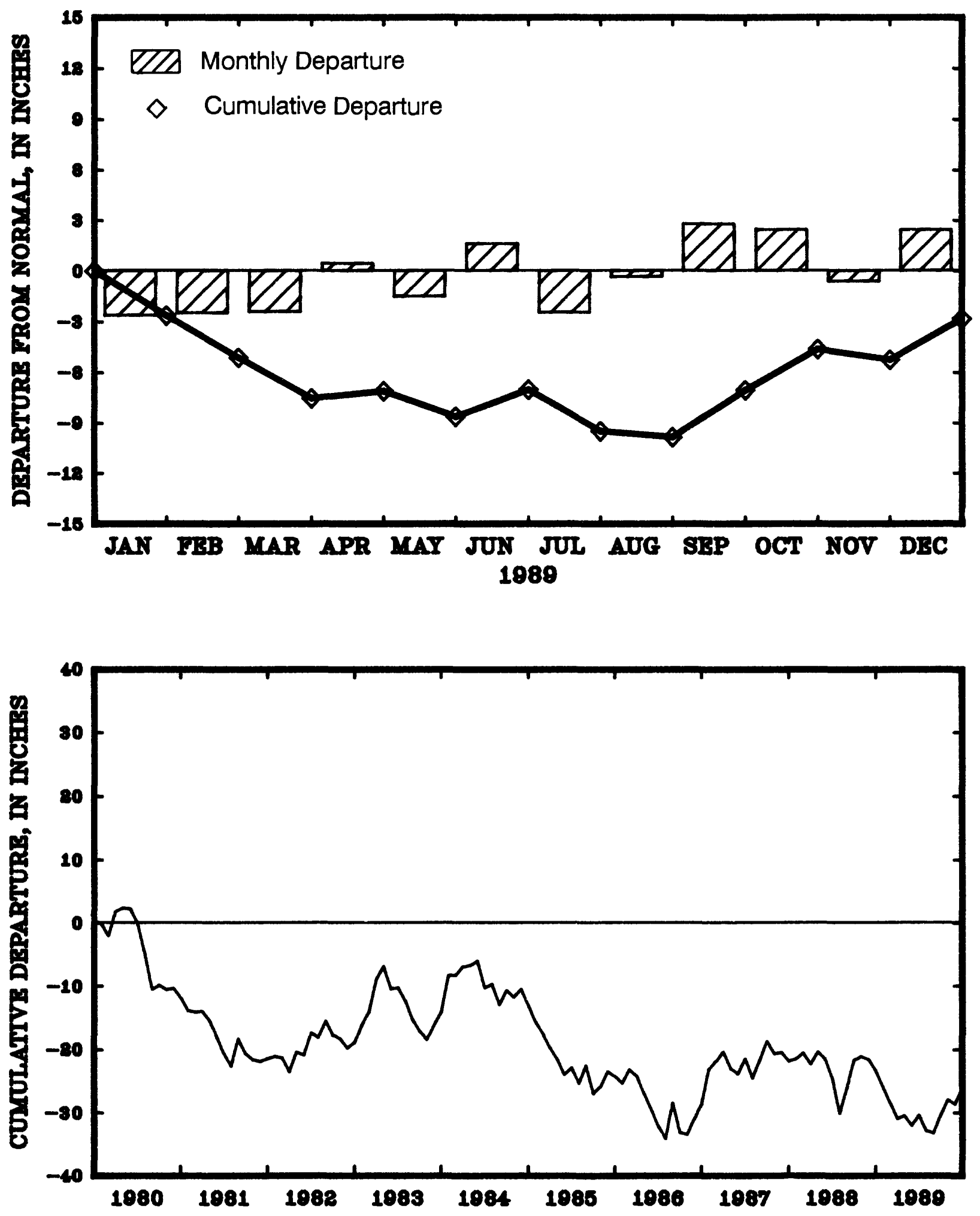

Figure 5.--Precipitation departure from normal for National Weather Service station at Savannah Weather Service Office, Airport, Chatham County. 

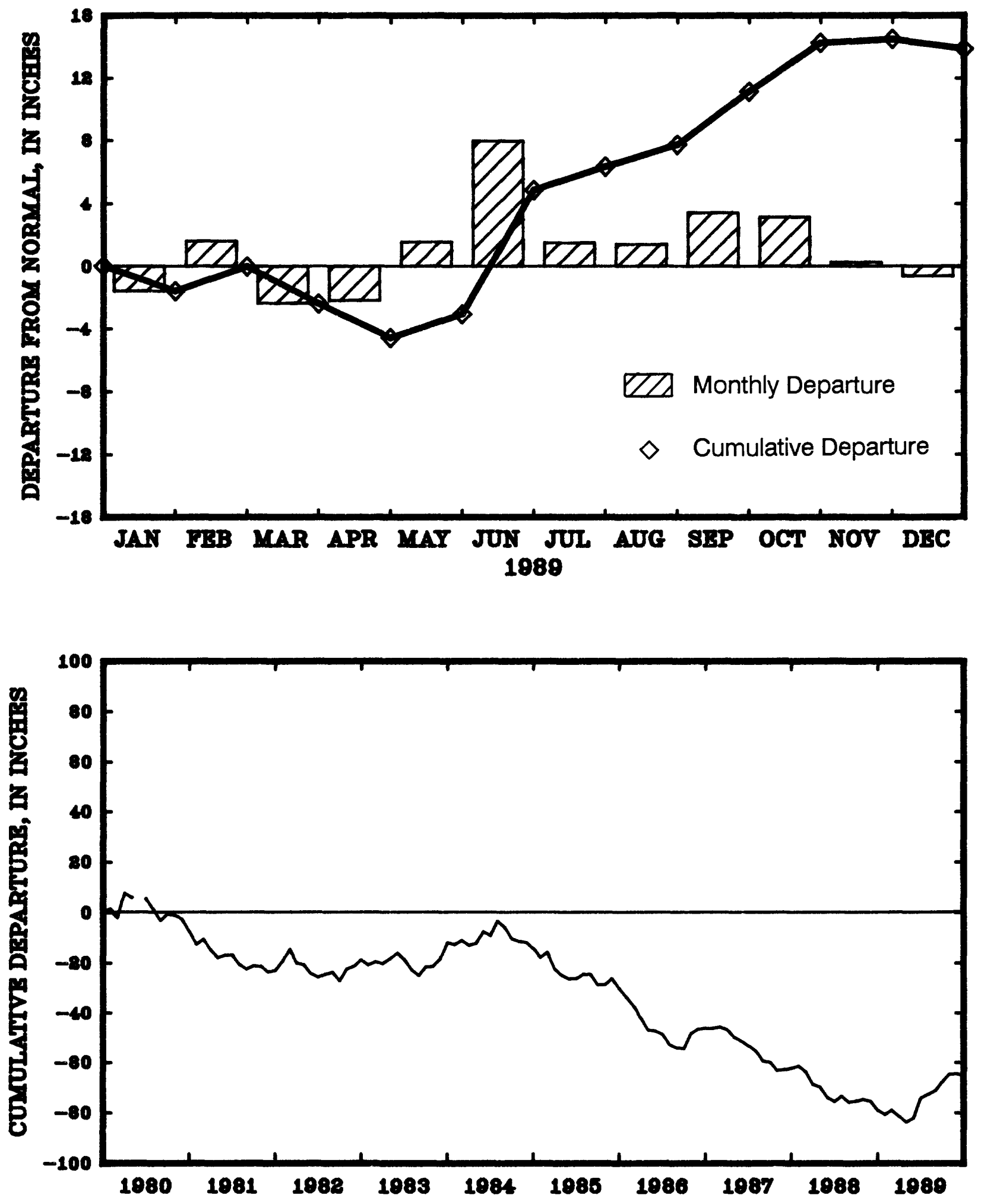

Figure 6.--Precipitation departure from normal for National Weather Service station at Cleveland, White County. 

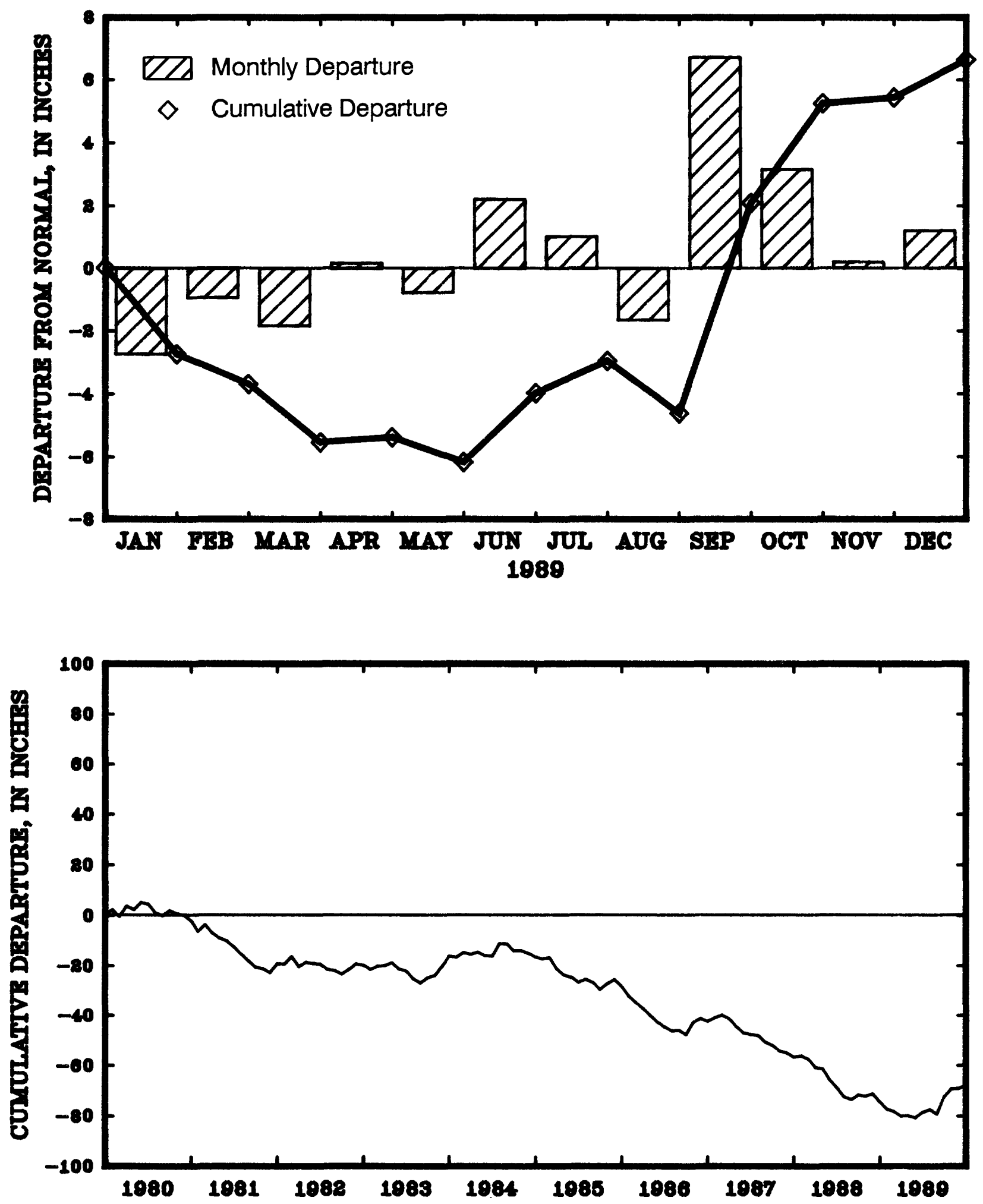

Figure 7.--Precipitation departure from normal for National Weather Service station at Athens Weather Service Office, Airport, Clarke County. 

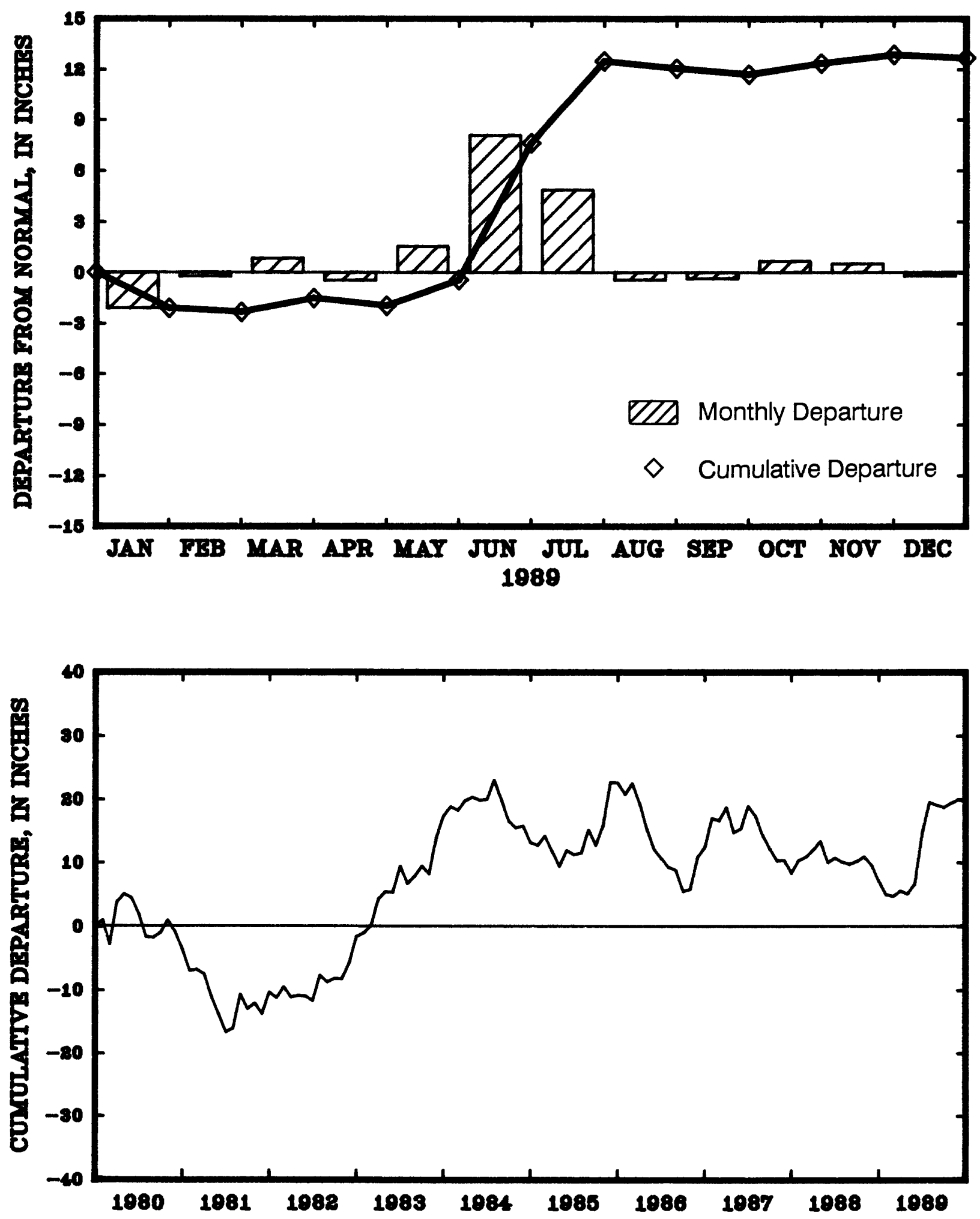

Figure 8.--Precipitation departure from normal for National Weather Service station at Albany 3 Southeast, Dougherty County. 

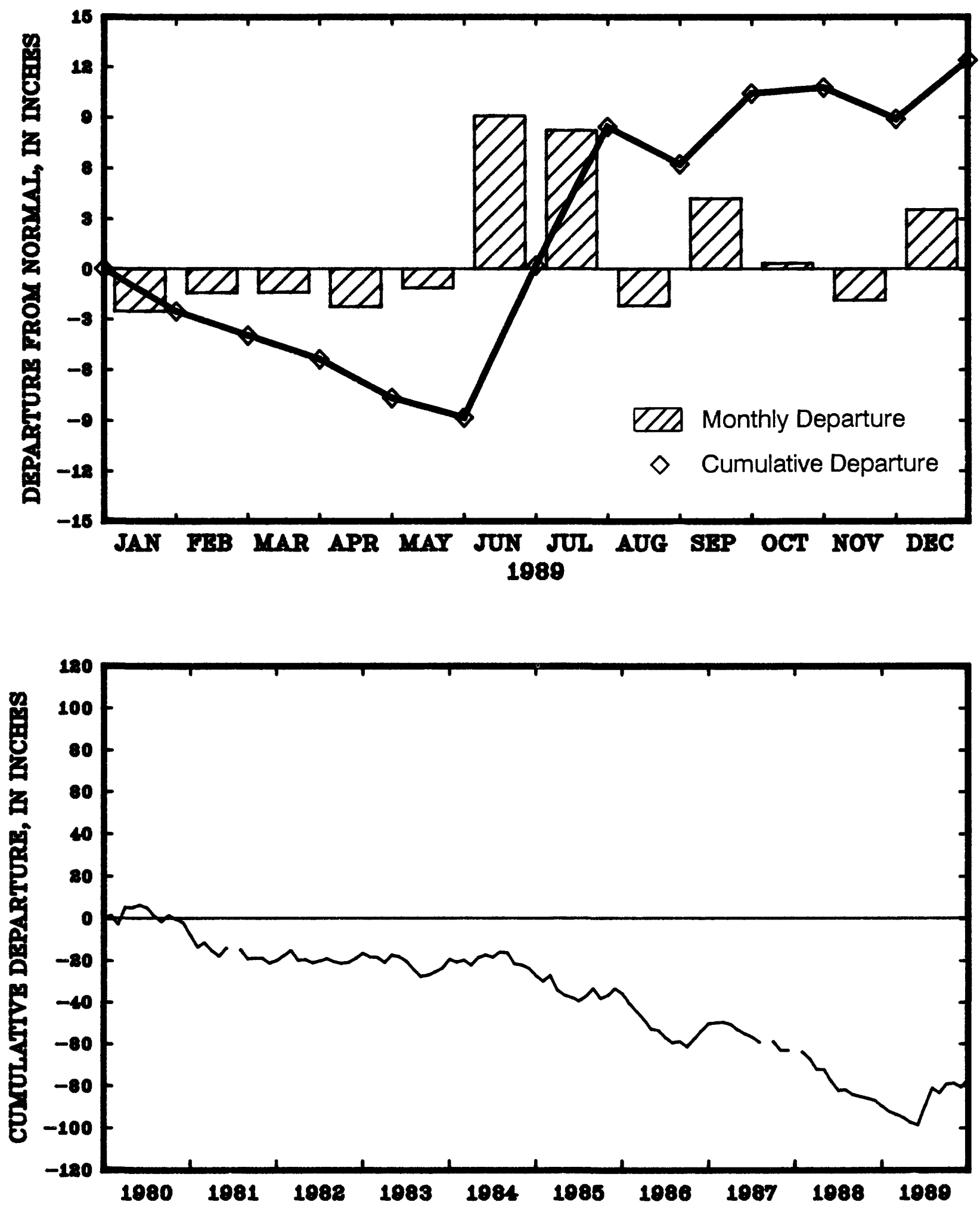

Figure 9.--Precipitation departure from normal for National Weather Service station at Clayton 1 South southwest, Rabun County. 

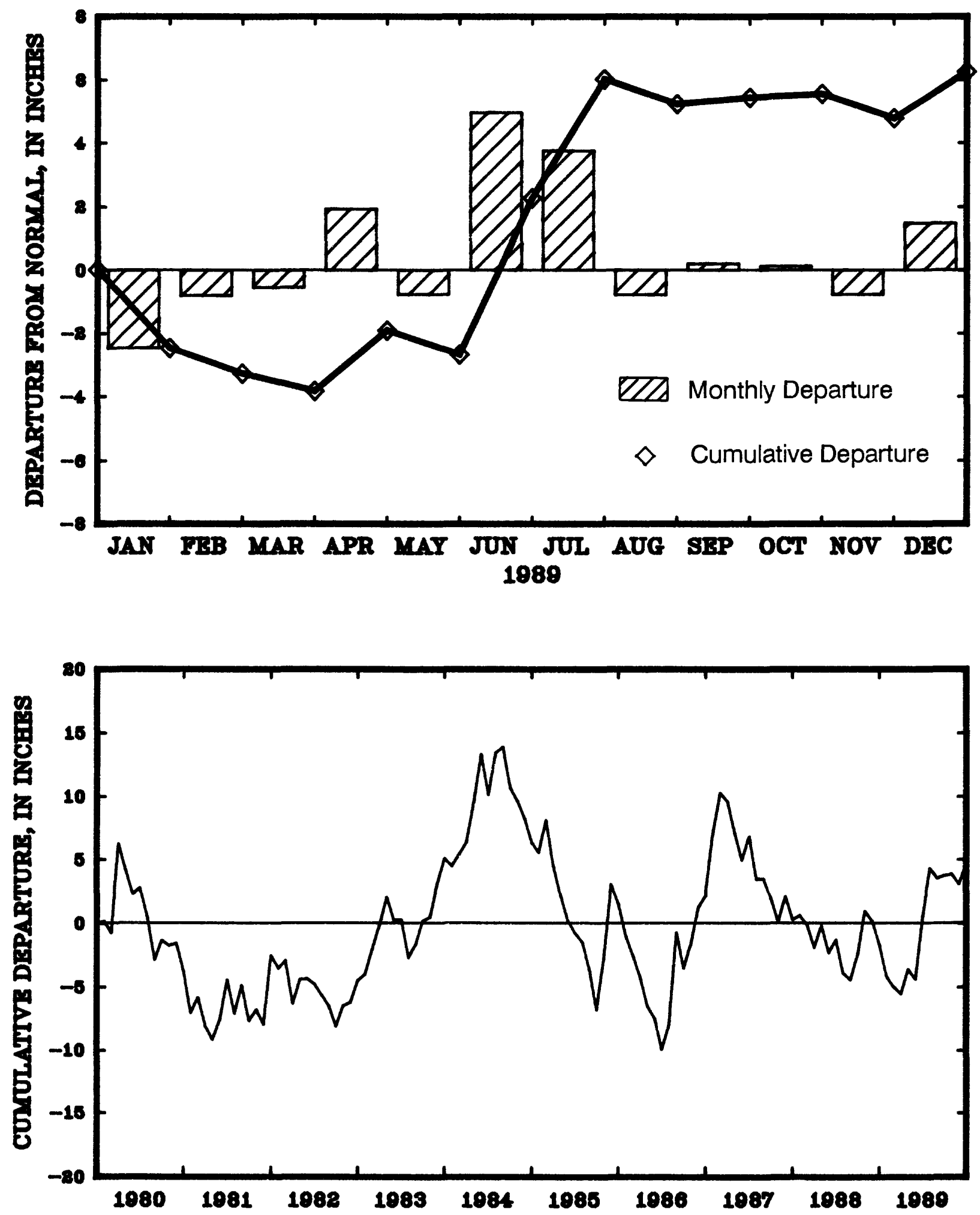

Figure 10.--Precipitation departure from normal for National Weather Service station at Augusta Weather Service Office, Airport, Richmond County. 

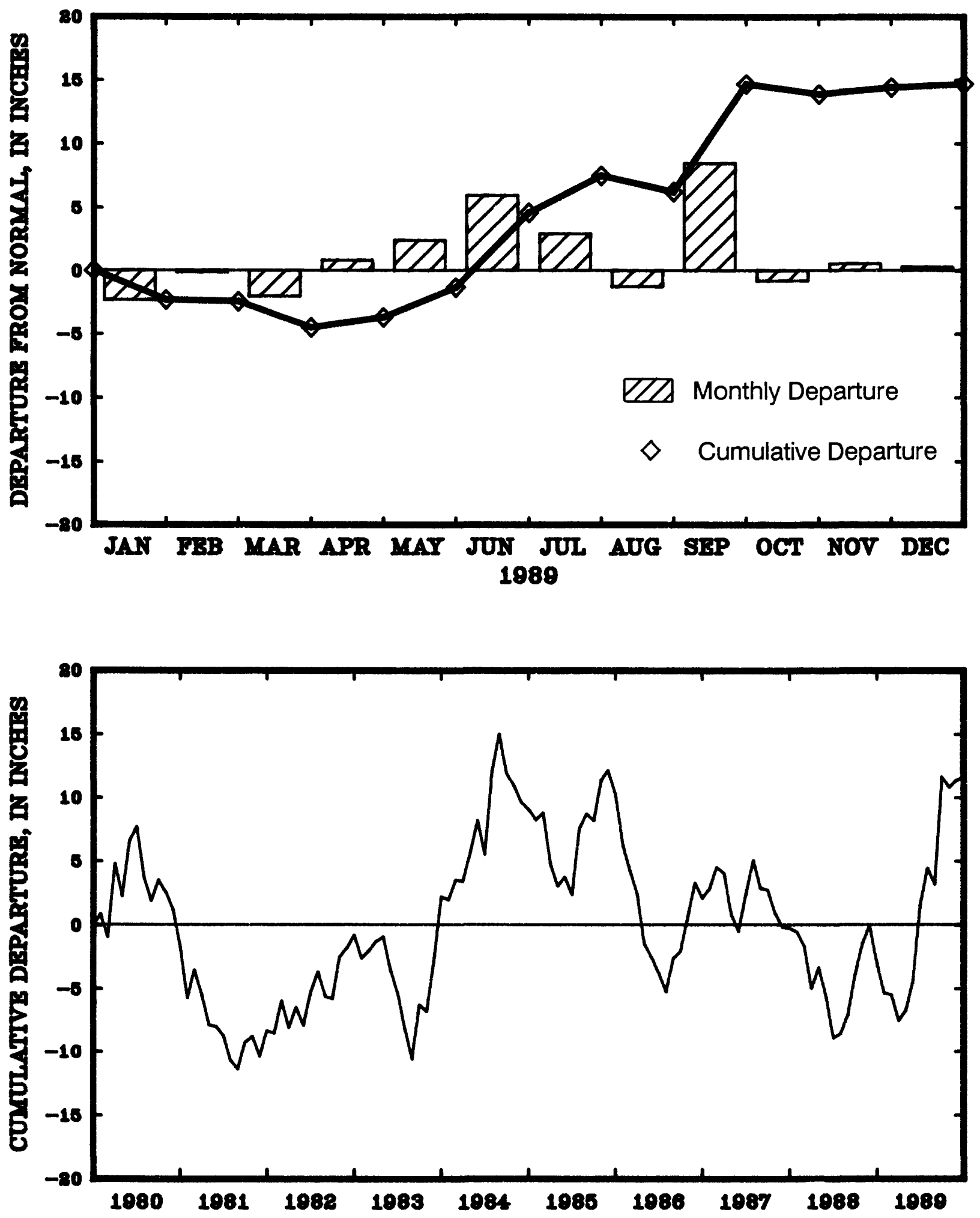

Figure 11.--Precipitation departure from normal for National Weather Service station at Atlanta Weather Service Office, Airport, Fulton County. 

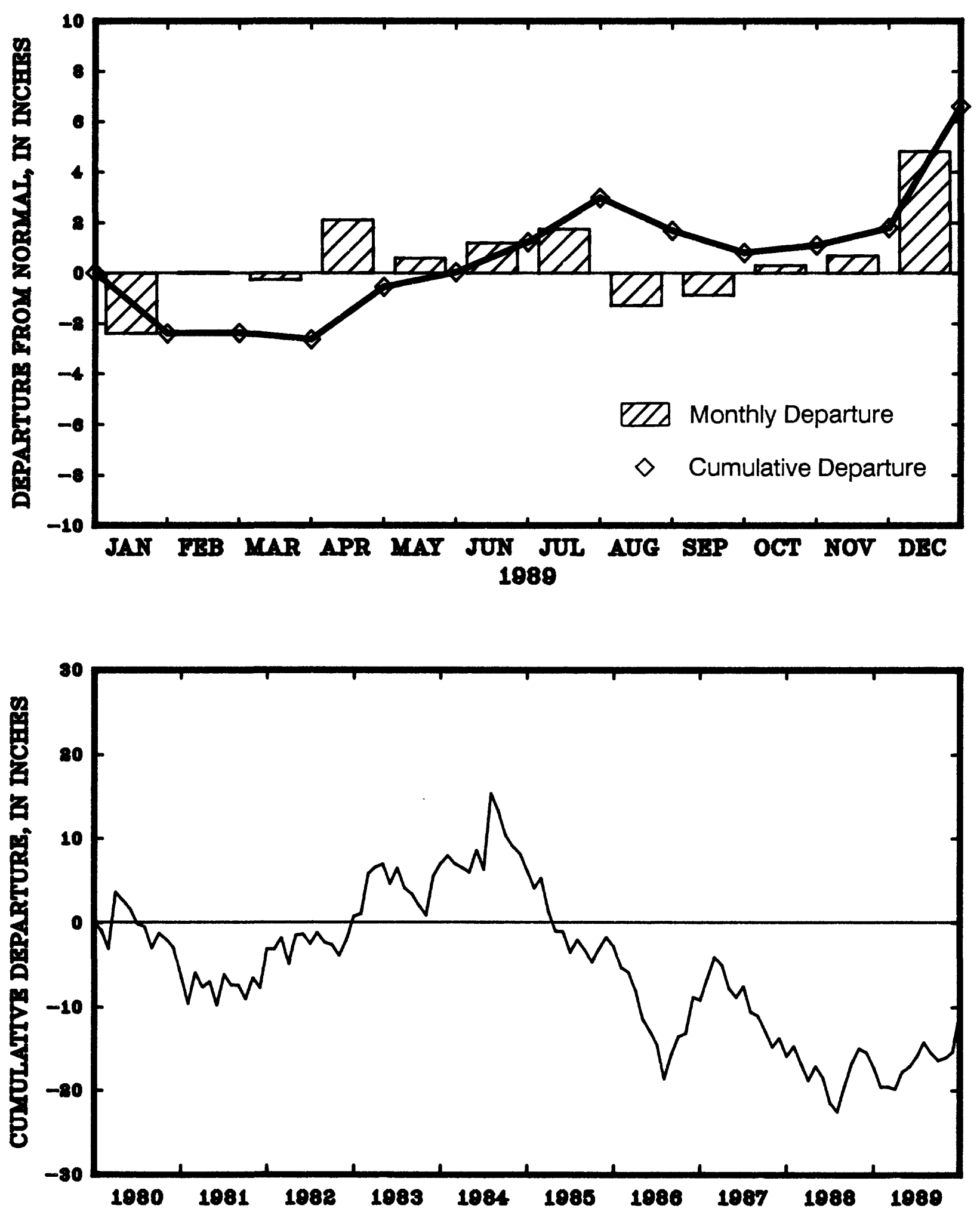

Figure 12.--Precipitation departure from normal for National Weather Service station at Macon Weather Service Office, Airport, Bibb County. 


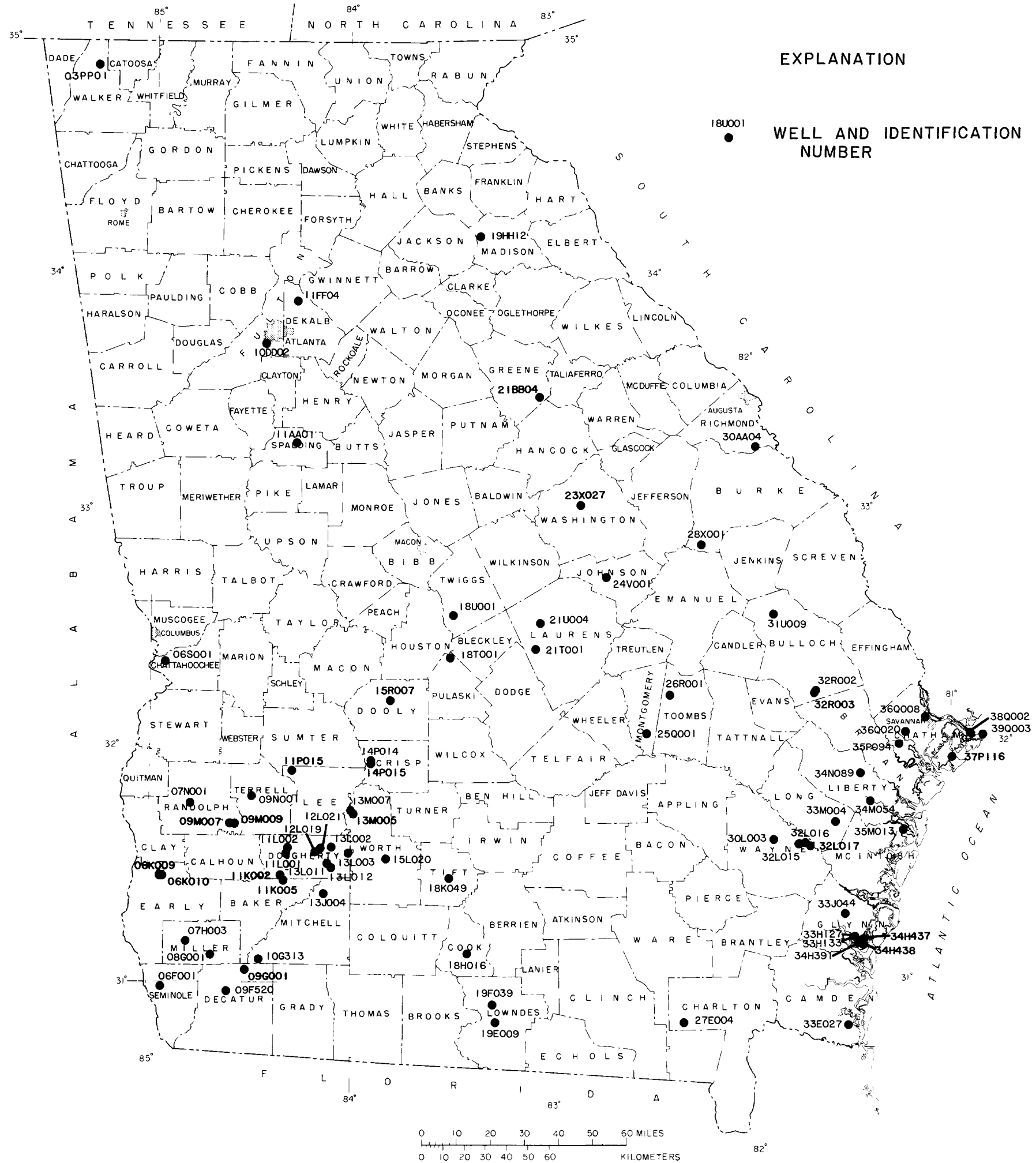

Figure 13.--Locations of observation wells for which hydrographs are included in this report. 
Table 2.--Observation wells for which water-level hydrographs are included in this report

County

Aquifer

Well

number

Well name

\begin{tabular}{|c|c|c|c|}
\hline Bulloch & Upper Floridan & 32R002 & Bulloch South test well 1 \\
\hline Bulloch & Surficial & 32R003 & Bulloch South test well 2 \\
\hline Bulloch & Upper Brunswick & 31U009 & Hopeulikit test well 2 \\
\hline Burke & Midville aquifer system & $28 \times 001$ & Midville Experiment Station \\
\hline Camden & Upper Floridan & 33E027 & Kings Bay \\
\hline Charlton & Upper Floridan & 27E004 & Test well OK9 \\
\hline Chatham & Surficial & 35P094 & UGA \\
\hline Chatham & Upper Floridan & $36 \mathrm{Q} 008$ & Layne-Atlantic \\
\hline Chatham & Upper Floridan & $36 \mathrm{Q} 020$ & Morrison \\
\hline Chatham & Surficial & 37P116 & Skidaway Institute test well 4 \\
\hline Chatham & Upper Floridan & $38 \mathrm{Q} 002$ & Pilot House \\
\hline Chatham & Upper Floridan & $39 Q 003$ & Test well 7 , point 3 \\
\hline Chattahoochee & $\begin{array}{l}\text { Cretaceous aquifer } \\
\text { system }\end{array}$ & $06 \mathrm{~S} 001$ & Fort Benning \\
\hline Cook & Upper Floridan & $18 \mathrm{H} 016$ & Adel \\
\hline Crisp & Clayton & 14P014 & $\begin{array}{l}\text { Georgia Veterans Memorial State } \\
\text { Park test well } 1\end{array}$ \\
\hline Crisp & Claiborne & 14P015 & $\begin{array}{l}\text { Georgia Veterans Memorial State } \\
\text { Park test well } 2\end{array}$ \\
\hline Decatur & Upper Floridan & $09 \mathrm{~F} 520$ & Bolton \\
\hline Decatur & Claiborne & 09G001 & DP-4 \\
\hline DeKalb & Crystalline rock & 11FF04 & GAR, test well 5 \\
\hline Dooly & Claiborne & 15R007 & Pinehurst-Horne \\
\hline Dougherty & Providence & $12 \mathrm{~L} 021$ & Test well 10 \\
\hline Dougherty & Claiborne & 11K002 & Test well 11 \\
\hline Dougherty & Clayton & 11K005 & Test well 12 \\
\hline Dougherty & Clayton & $11 \mathrm{~L} 002$ & Albany Nursery \\
\hline Dougherty & Clayton & $13 \mathrm{~L} 002$ & Turner City \\
\hline Dougherty & Claiborne & 11L001 & Test well 4 \\
\hline Dougherty & Claiborne & 12L019 & Test well 5 \\
\hline Dougherty & Claiborne & 13L011 & Test well 2 \\
\hline Dougherty & Upper Floridan & $13 \mathrm{~L} 003$ & Albany-Dougherty County \\
\hline Dougherty & Upper Floridan & $13 \mathrm{~L} 012$ & Test well 3 \\
\hline Early & Clayton & 06K009 & Kolomoki State Park test well 1 \\
\hline Early & Claiborne & $06 \mathrm{~K} 010$ & Kolomoki State Park test well 2 \\
\hline Fulton & Crystalline rock & 10DD02 & Fort McPherson \\
\hline Glynn & Upper Floridan & $33 \mathrm{H} 127$ & Test well 3 \\
\hline Glynn & Upper Floridan & $33 \mathrm{H} 133$ & Test well 6 \\
\hline Glynn & Lower Floridan & $33 \mathrm{~J} 044$ & Test well 27 \\
\hline Glynn & Lower Floridan & 34H391 & Test well 16 \\
\hline Glynn & Upper Brunswick & $34 \mathrm{H} 437$ & Coffin Park test well 2 \\
\hline Glynn & Surficial & $34 \mathrm{H} 438$ & Coffin Park test well 3 \\
\hline Greene & Crystalline rock & 21BB04 & Veasey \\
\hline Johnson & Midville aquifer system & $24 \mathrm{~V} 001$ & Test well 1 \\
\hline Laurens & Upper Floridan & 21T001 & Hogan \\
\hline Laurens & Midville aquifer system & 21U004 & Test well 3 \\
\hline Lee & Claiborne & 11P015 & Pete Long 2 \\
\hline
\end{tabular}


Table 2.--Observation wells for which water-level hydrographs are included in this report--Continued

\begin{tabular}{|c|c|c|c|}
\hline County & Aquifer & $\begin{array}{c}\text { Well } \\
\text { number }\end{array}$ & Well name \\
\hline Liberty & Upper Floridan & $34 \mathrm{M} 054$ & Test well 2 \\
\hline Liberty & Upper Floridan & 34 N089 & Test well 1 \\
\hline Long & Upper Floridan & $33 \mathrm{M} 004$ & Test well 3 \\
\hline Lowndes & Upper Floridan & 19E009 & Valdosta \\
\hline Lowndes & Upper Floridan & 19F039 & Valdosta 8 \\
\hline Madison & Crystalline rock & 19HН12 & Meadowlake Estates \\
\hline McIntosh & Upper Floridan & $35 \mathrm{M} 013$ & Harris Neck \\
\hline Miller & Surficial & $07 \mathrm{H} 003$ & DP-3 \\
\hline Miller & Upper Floridan & 08G001 & Fleet \\
\hline Mitchell & Upper Floridan & $10 \mathrm{G} 313$ & Meinders \\
\hline Mitchell & Upper Floridan & $13 \mathrm{~J} 004$ & Wright \\
\hline Montgomery & Upper Floridan & $25 \mathrm{Q} 001$ & Uvalda School \\
\hline Pulaski & Midville aquifer system & $18 \mathrm{~T} 001$ & Arrowhead test well 1 \\
\hline Randolph & Clayton & 07N001 & Cuthbert \\
\hline Randolph & Clayton & $09 \mathrm{M} 007$ & Martin test well 2 \\
\hline Randolph & Claiborne & 09M009 & Martin test well 1 \\
\hline Richmond & $\begin{array}{l}\text { Dublin-Midville } \\
\text { aquifer system }\end{array}$ & 30AA04 & McBean 2 \\
\hline Seminole & Upper Floridan & $06 \mathrm{~F} 001$ & Roddenberry Farms test well 1 \\
\hline Spalding & Surficial & 11AA01 & Experiment Station \\
\hline Terrell & Clayton & $09 \mathrm{~N} 001$ & Graves School \\
\hline Tift & Upper Floridan & 18K049 & Test well 1 \\
\hline Toombs & Upper Floridan & 26R001 & Vidalia 2 \\
\hline Twiggs & Dublin aquifer system & 18U001 & Test well 3 \\
\hline Walker & Paleozoic rock & 03PP01 & Fort Oglethorpe \\
\hline Washington & $\begin{array}{l}\text { Dublin-Midville } \\
\text { aquifer system }\end{array}$ & $23 \times 027$ & Sandersville Ga 8 \\
\hline Wayne & Upper Floridan & 30L003 & Johnson \\
\hline Wayne & Upper Floridan & $32 L 015$ & Gardi test well 1 \\
\hline Wayne & Upper Brunswick & $32 \mathrm{LO} 16$ & Gardi test well 2 \\
\hline Wayne & Surficial & $32 \mathrm{~L} 017$ & Gardi test well 3 \\
\hline Worth & Claiborne & 13M005 & DP-7 \\
\hline Worth & Surficial & 13M007 & DP-9 \\
\hline Worth & Upper Floridan & $15 \mathrm{LO} 020$ & Sylvester \\
\hline
\end{tabular}

Continuous records from 76 wells indicate that annual mean ground-water levels during 1989 were from $4.1 \mathrm{ft}$ lower to $10.8 \mathrm{ft}$ higher than annual means during 1988. When compared to 1988 records, the annual mean water level during 1989 was higher in 39 wells and lower in 37 wells. During the period 1980-89, the overall water-level trend was downward in 50 of the 76 wells included in this report. In the Coastal Plain, record-low water levels were measured during 1989 in nine wells, and were from 0.1 to $1.1 \mathrm{ft}$ lower than the previous record lows. The record lows were measured during December in the Cretaceous aquifer system near Columbus; during February in the Clayton aquifer in southwestern Dougherty County; and during June to September and during December in the Upper Floridan, Lower Floridan, and upper Brunswick aquifers in the Coastal area. 


\section{Surficial Aquifers}

Water-level fluctuations and trends in the surficial aquifers are monitored in 13 wells statewide, records from eight are included in this report (figs. 14-22). Water-level fluctuations in the surficial aquifers are caused mainly by changes in precipitation, evapotranspiration, and natural drainage. Generally, water levels rise rapidly during wet periods and decline slowly during dry periods. Prolonged droughts may cause water levels to decline below pump intakes in shallow wells, particularly those located on hill tops and steep slopes, resulting in temporary well failures. Generally, well yields are restored with the return of precipitation. In some areas, the surficial aquifer is semi-confined and water levels are influenced locally by nearby pumping.

\section{North Georgia area}

Water-level fluctuations and trends in the surficial aquifer in the northern part of Georgia are monitored locally in two wells, records from one are included in this report. In this area, water levels in the surficial aquifer are affected by variations in precipitation, as illustrated by the hydrograph for well 11AA01 (fig. 15) at Griffin, Spalding County. The 10-yr hydrograph indicates that water levels in the well were affected by severe droughts in 1981, 1986, and 1988. (see precipitation graph for Atlanta, fig. 11.) The general trend in the water level was slightly downward during 1983-88, but above normal precipitation during 1984, 1987, and 1989 resulted in increased recharge to the aquifer and higher water levels. The mean water level in well 11AA01 was $0.9 \mathrm{ft}$ higher in 1989 than in 1988.

\section{Southwest area}

In the southwest area, five wells are monitored to detect water-level fluctuations and trends in the surficial aquifer, records from two are included in this report (figs. 16, 17). Water-level fluctuations in these two wells are directly related to localized precipitation events. The mean water level in well 13M007 (fig. 16) in Worth County was $0.8 \mathrm{ft}$ lower and the mean water level in well $07 \mathrm{H} 003$ (fig. 17) in Miller County was $2.1 \mathrm{ft}$ higher in 1989 than in 1988. The 10-yr hydrographs indicate that water levels in both wells were affected by a severe drought in 1981. A slight downward trend during 1983-89 is evident in well 13M007, but no trend is apparent in the hydrograph for well $07 \mathrm{H} 003$. The difference in water-level response at the two wells results from areal variations in precipitation.

\section{Coastal area}

Water levels in the surficial aquifer in the coastal area are monitored in six wells, records from five are included in this report (figs. 18-22). Throughout the coastal area, the surficial aquifer is recharged by precipitation, as illustrated by the hydrographs for wells 35P094 and 37P116 in Chatham County (figs. 18, 19), and well 32R003 in Bulloch County (fig. 20). At well 35P094, recharge by precipitation is reflected by a sharp rise in the water level followed by a gradual decline that represents evapotranspiration and natural drainage (Clarke and others, 1990, p. 22). The water-level response at wells 32R003 and 37P116 is less pronounced because the wells tap deeper parts of the surficial aquifer where semi-confined conditions occur as a result of a clay semi-confining unit. The annual mean water level in well 37P116 in Chatham County was about the same in 1989 as in 1988; in well 32R003 in Bulloch County the annual mean water level was about $0.7 \mathrm{ft}$ higher and in well 35P094 it was about $0.3 \mathrm{ft}$ lower in 1989 than in 1988. There is no apparent long-term trend indicated on the 10-yr graphs for these wells.

Water-level fluctuations in the surficial aquifer in the Brunswick area are influenced by nearby pumping from the surficial aquifer, by precipitation, and by tidal fluctuations (Clarke and others, 1990, p. 24). The mean water level in well 34H438 (fig. 21) in Glynn County was $0.3 \mathrm{ft}$ higher in 1989 than in 1988, reversing a slight downward trend since at least 1984 (when monitoring began). The water-level rise during 1988-89 may be a result of increased precipitation and decreased pumping. 


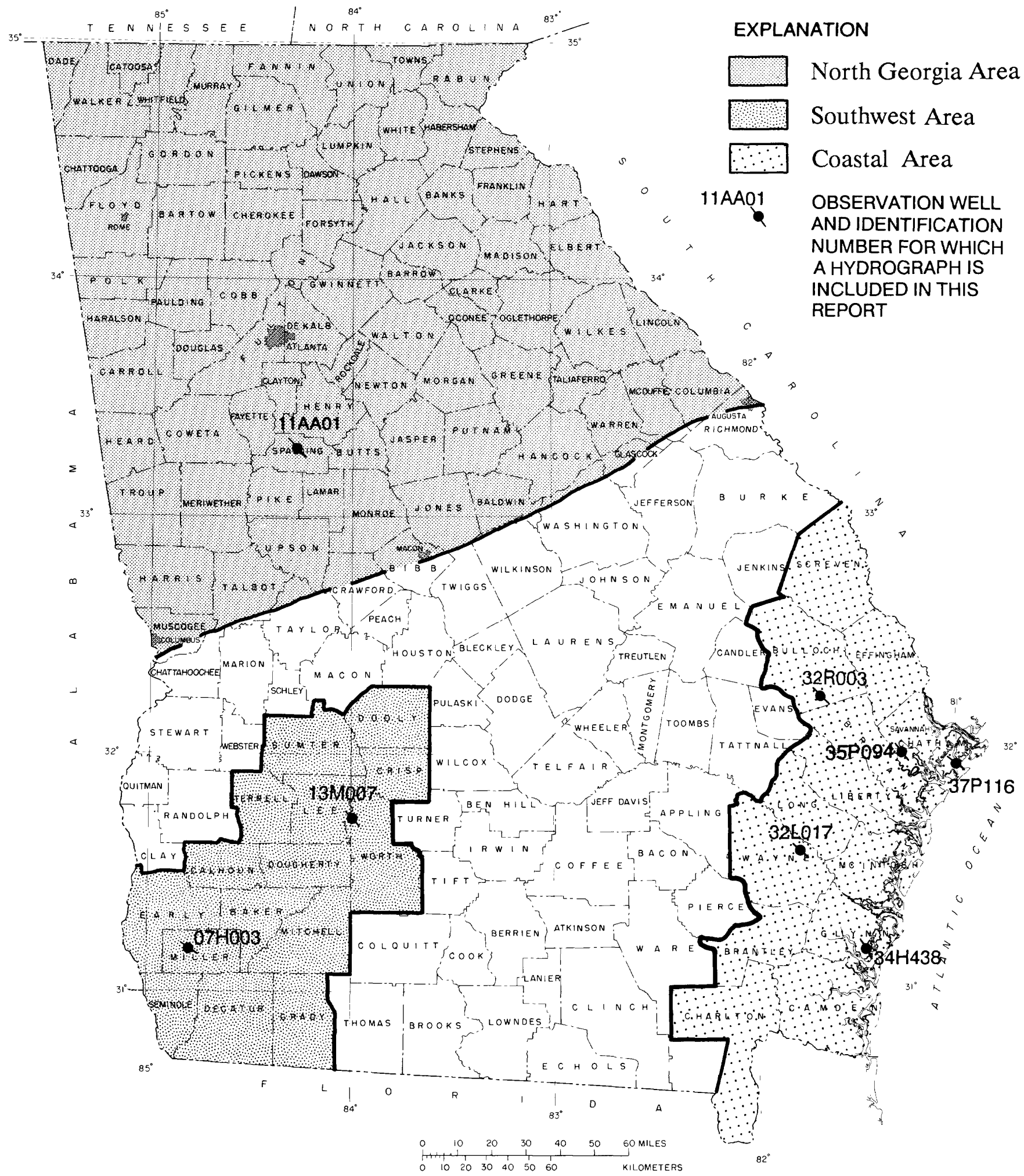

Figure 14.--Locations of observation wells completed in surficial aquifers. 
331507084171801 Local number, $11 \mathrm{AA01}$.

LOCATION.--Lat $33^{\circ} 15^{\prime} 54^{\prime \prime}$, long 84 16'56", Hydrologic Unit 03070103, University of Georgia Experiment Station,

Experiment, Ga.

Owner: University of Georgia.

AQUIFER.--Surficial (residuum).

WELL CHARACTERISTICS.--Dug unused supply well, size $4 \times 4 \mathrm{ft}$, depth $30 \mathrm{ft}$, cased to $30 \mathrm{ft}$, open end.

DATUM.--Altitude of land-surface datum is $950 \mathrm{ft}$.

Measuring point: Top of recorder shelf, $3.1 \mathrm{ft}$ above land-surface datum.

REMARKS.--None.

PERIOD OF RECORD.--October 1943 to current year.

EXTREMES FOR PERIOD OF RECORD.--Highest water level, $8.26 \mathrm{ft}$ below land-surface datum, March 19, 1948; lowest,

$21.82 \mathrm{ft}$ below land-surface datum, November 18-19, 1986.
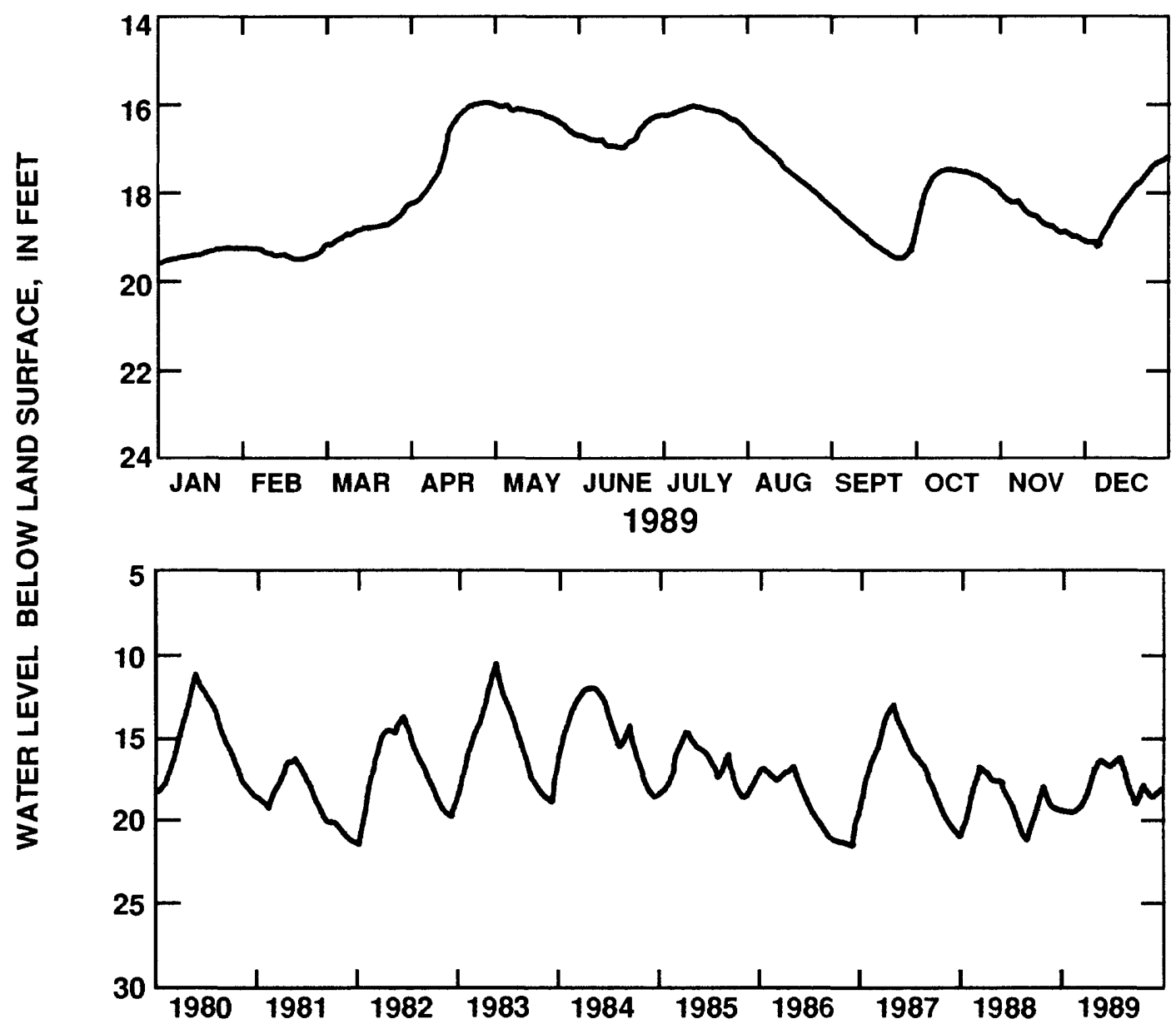

\begin{tabular}{|c|c|c|c|c|c|c|c|c|c|c|c|c|}
\hline 1989 & JAN & FEB & MAR & APR & MAY & JUN & JUL & AUG & SEP & OCT & NOV & DEC \\
\hline $\begin{array}{l}\text { MEAN } \\
\text { MAX } \\
\text { MIN }\end{array}$ & $\begin{array}{l}19.40 \\
19.57 \\
19.28\end{array}$ & $\begin{array}{l}19.43 \\
19.58 \\
19.21\end{array}$ & $\begin{array}{l}18.79 \\
19.24 \\
18.23\end{array}$ & $\begin{array}{l}16.82 \\
18.26 \\
15.97\end{array}$ & $\begin{array}{l}16.27 \\
16.66 \\
16.01\end{array}$ & $\begin{array}{l}16.73 \\
17.05 \\
16.25\end{array}$ & $\begin{array}{l}16.21 \\
16.58 \\
16.01\end{array}$ & $\begin{array}{l}17.46 \\
18.30 \\
16.64\end{array}$ & $\begin{array}{l}19.01 \\
19.48 \\
18.35\end{array}$ & $\begin{array}{l}17.76 \\
19.02 \\
17.47\end{array}$ & $\begin{array}{l}18.54 \\
19.01 \\
18.00\end{array}$ & $\begin{array}{l}18.27 \\
19.18 \\
17.24\end{array}$ \\
\hline CAL Y & 1989 & & MEAN & 17.88 & & $\mathrm{HIGH}$ & 15.97 & & LOW & 19.58 & & \\
\hline
\end{tabular}

Figure 15.--Water level in observation well 11AA01, Spalding County. 
314330084005403 Local number, $13 \mathrm{M} 007$.

LOCATION.--Lat 31 43'30", long $84^{\circ} 00^{\prime} 54^{\prime \prime}$, Hydrologic Unit 03130006, westernmost of three observation wells, $50 \mathrm{ft}$ north of Ga. Highway 32, 1,400 ft east of the Flint River, $1.7 \mathrm{mi}$ east of the intersection of Ga. Highway 32 and Ga.

Highway 91 .

Owner: U.S. Geological Survey test well DP-9.

AQUIFER.--Surficial (residuum).

WELL CHARACTERISTICS.--Drilled observation well, diameter 4 in., depth $25 \mathrm{ft}$, cased to $10 \mathrm{ft}$, open hole.

DATUM.--Altitude of land-surface datum is $230 \mathrm{ft}$.

Measuring point: Top of $4 \mathrm{in}$. casing, $1 \mathrm{ft}$ above land-surface datum.

REMARKS.--Water levels for period of missing record, February 28 to March 28, were estimated.

PERIOD OF RECORD.--April 1980 to current year.

EXTREMES FOR PERIOD OF RECORD.--Highest water level, $3.48 \mathrm{ft}$ below land-surface datum, March 7, 1984; lowest, $13.03 \mathrm{ft}$ below land-surface datum, October 22, 1981.
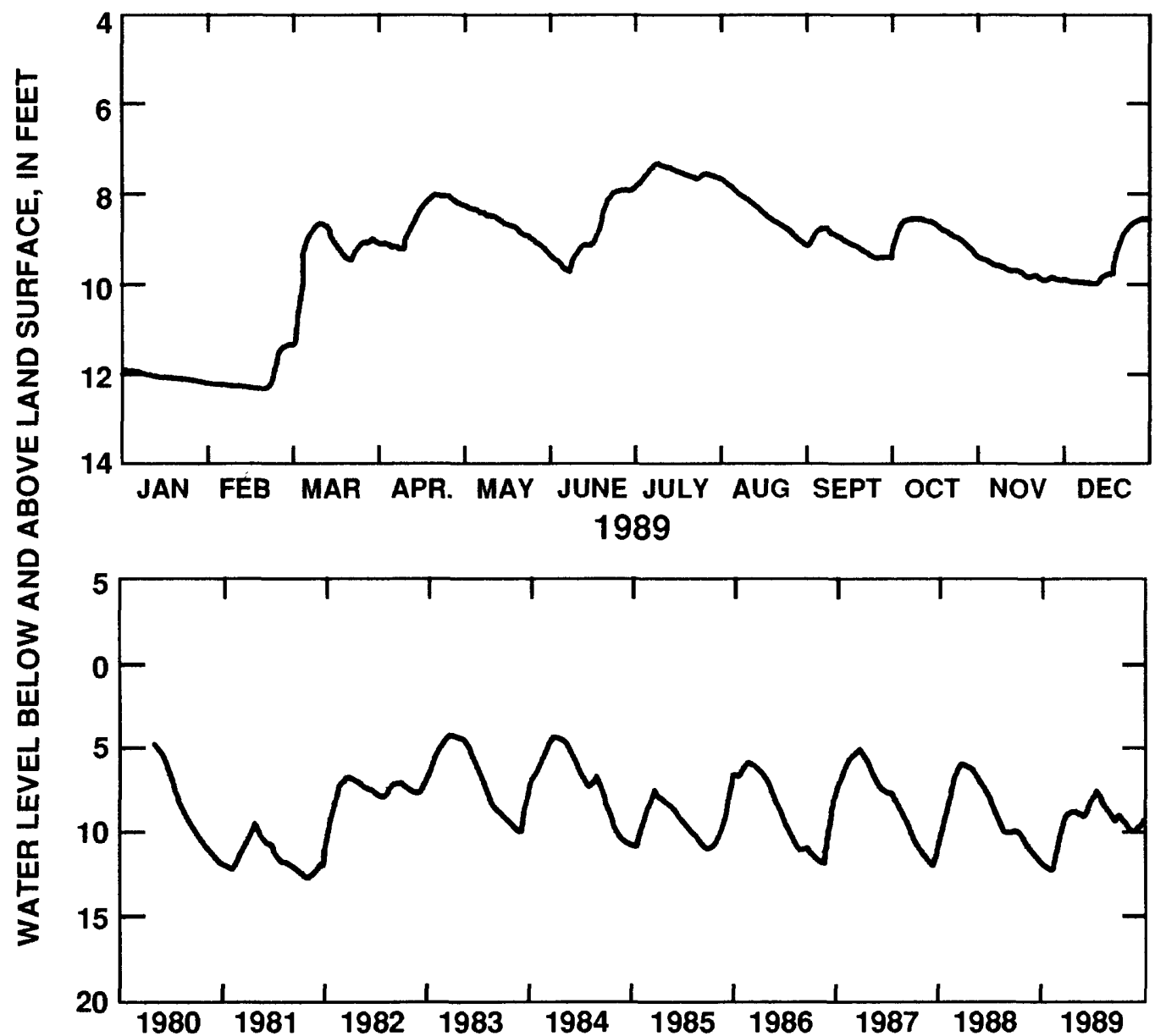

\begin{tabular}{|c|c|c|c|c|c|c|c|c|c|c|c|c|}
\hline 1989 & JAN & FEB & MAR & APR & MAY & JUN & JUL & $\mathbf{A U G}$ & SEP & OCT & NOV & DEC \\
\hline $\begin{array}{l}\text { MEAN } \\
\text { MAX } \\
\text { MIN }\end{array}$ & $\begin{array}{l}12.04 \\
12.22 \\
11.86\end{array}$ & $\begin{array}{r}12.08 \\
12.30 \\
11.30\end{array}$ & $\begin{array}{r}9.25 \\
11.34 \\
8.62\end{array}$ & $\begin{array}{l}8.47 \\
9.18 \\
7.92\end{array}$ & $\begin{array}{l}8.65 \\
9.30 \\
8.17\end{array}$ & $\begin{array}{l}8.82 \\
9.69 \\
7.86\end{array}$ & $\begin{array}{l}7.52 \\
7.88 \\
7.29\end{array}$ & $\begin{array}{l}8.42 \\
9.12 \\
7.68\end{array}$ & $\begin{array}{l}9.15 \\
9.50 \\
8.75\end{array}$ & $\begin{array}{l}8.90 \\
9.39 \\
8.54\end{array}$ & $\begin{array}{l}9.75 \\
9.97 \\
9.45\end{array}$ & $\begin{array}{r}9.49 \\
10.03 \\
8.50\end{array}$ \\
\hline CAL Y & 1989 & & MEAN & 9.36 & & HIGH & 7.29 & & LOW & 12.30 & & \\
\hline
\end{tabular}

Figure 16.--Water level in observation well 13M007, Worth County. 
311009084495503 Local number, $07 \mathrm{H003}$.

LOCATION,--Lat 31 10'08", long 84'49'54", Hydrologic Unit 03130010, 0.2 mi north on dirt road off Ga. Highway 273, $2.75 \mathrm{mi}$ west of intersection of Ga. Highways 273 and 91.

Owner: U.S. Geological Survey test well DP-3.

AQUIFER.--Surficial (residuum).

WELL CHARACTERISTICS.--Drilled observation well, diameter 4 in., depth $40 \mathrm{ft}$, perforated casing 30 to $40 \mathrm{ft}$.

DATUM.--Altitude of land-surface datum is $180 \mathrm{ft}$.

Measuring point: Top of recorder shelf, $3.0 \mathrm{ft}$ above land-surface datum.

REMARKS.--Well pumped and redeveloped August 11, 1989. Water levels for period of missing record, August 11-12, were estimated.

PERIOD OF RECORD.--February 1980 to current year.

EXTREMES FOR PERIOD OF RECORD.--Highest water level, $0.52 \mathrm{ft}$ below land-surface datum, March 6, 1984; lowest,

$24.19 \mathrm{ft}$ below land-surface datum, November 10, 1981.

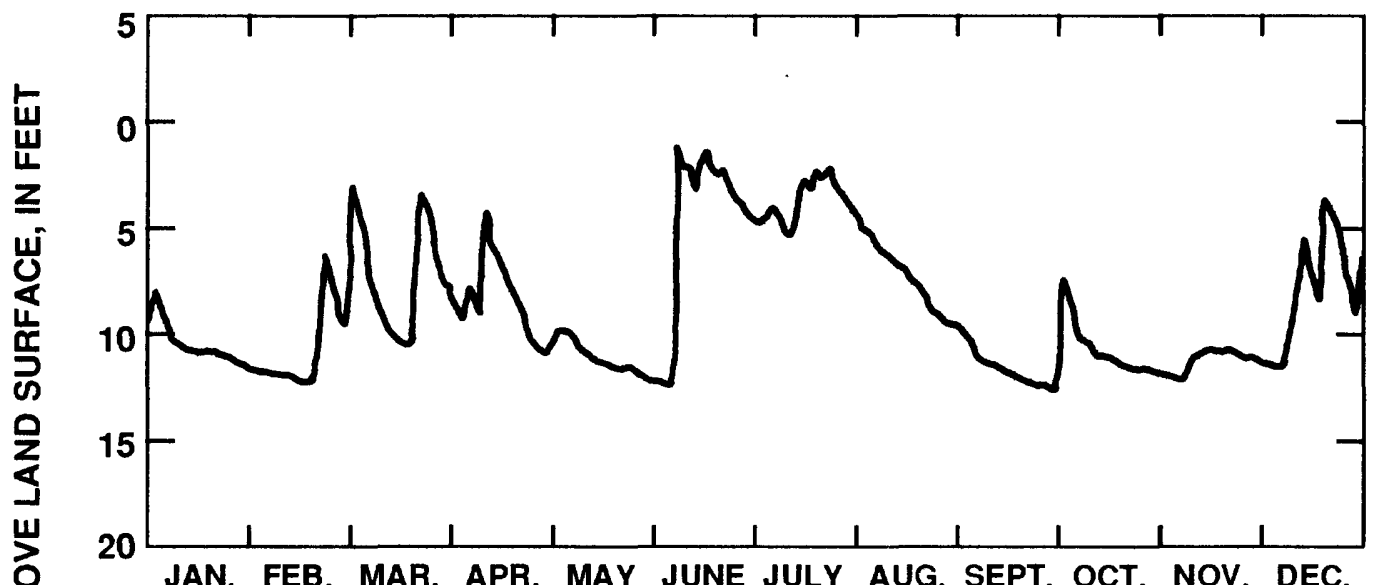

JAN. FEB. MAR. APR. MAY JUNE JULY AUG. SEPT. OCT. NOV. DEC. 1989

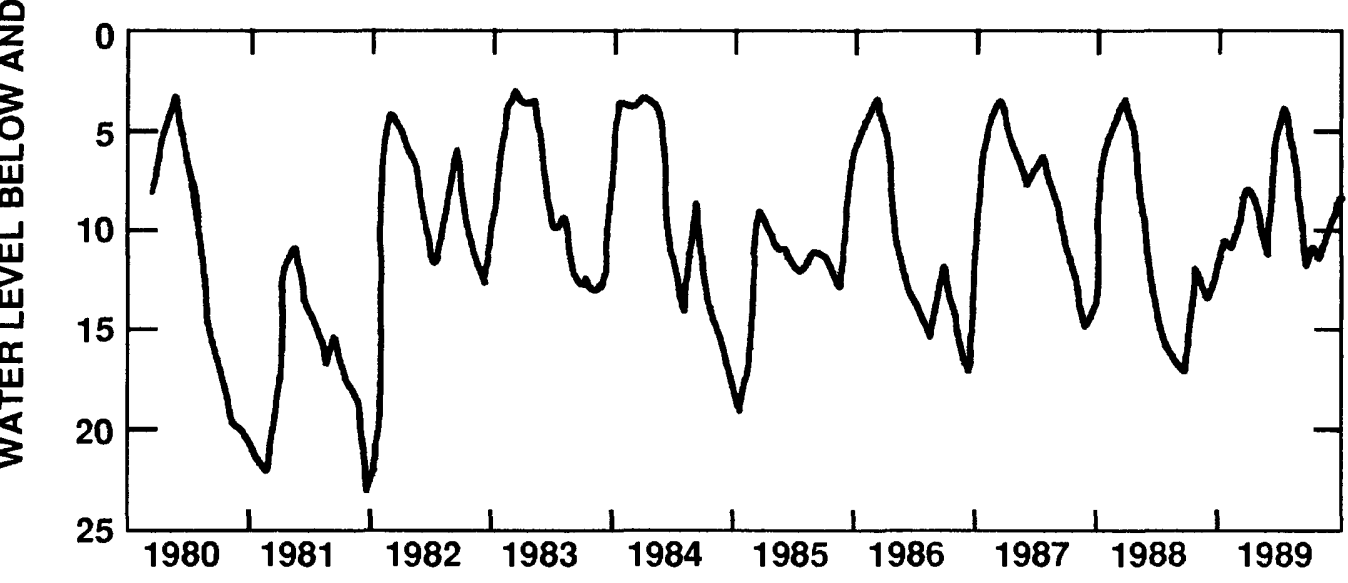

\begin{tabular}{|c|c|c|c|c|c|c|c|c|c|c|c|c|}
\hline 1989 & JAN & FEB & MAR & APR & MAY & JUN & JUL & AUG & SEP & OCT & NOV & DEC \\
\hline $\begin{array}{l}\text { IEAN } \\
\text { AXX } \\
\text { INN }\end{array}$ & $\begin{array}{r}10.43 \\
11.55 \\
7.85\end{array}$ & $\begin{array}{r}10.93 \\
12.24 \\
6.30\end{array}$ & $\begin{array}{r}7.59 \\
10.39 \\
3.18\end{array}$ & $\begin{array}{r}8.18 \\
10.89 \\
4.28\end{array}$ & $\begin{array}{r}11.16 \\
12.16 \\
9.87\end{array}$ & $\begin{array}{r}5.28 \\
12.45 \\
1.32\end{array}$ & $\begin{array}{l}3.87 \\
5.50 \\
2.09\end{array}$ & $\begin{array}{l}7.17 \\
9.54 \\
4.39\end{array}$ & $\begin{array}{r}11.67 \\
12.65 \\
9.64\end{array}$ & $\begin{array}{r}10.77 \\
11.86 \\
7.55\end{array}$ & $\begin{array}{l}11.29 \\
12.22 \\
10.72\end{array}$ & $\begin{array}{r}8.23 \\
11.53 \\
3.70\end{array}$ \\
\hline$A L Y$ & 1989 & & MEAN & 8.86 & & $\mathrm{HIGH}$ & 1.32 & & LOW & 12.65 & & \\
\hline
\end{tabular}

Figure 17.--Water level in observation well $07 \mathrm{H} 003$, Miller County. 
315950081161201 Local number, $35 P 094$.

LOCATION.--Lat 31 59'50", long 81 '16'12", Hydrologic Unit 03060204, Barbour Lathrop Plant Introduction Station,

$10 \mathrm{mi}$ south of Savannah, north of the intersection of U.S. Highway 17 and Argyle Rd.

Owner: University of Georgia, formerly U.S. Department of Agriculture.

AQUIFER.--Surficial (sand of Holocene and Pleistocene age).

WELL CHARACIERISTICS.--Bored observation well, diameter 30 in., depth $15 \mathrm{ft}$, cased to $15 \mathrm{ft}$, open end.

DATUM.--Altitude of land-surface datum is $18.67 \mathrm{ft}$.

Measuring point: Iron bracket on recorder shelf, $3.3 \mathrm{ft}$ above land-surface datum.

REMARKS.--Responds quickly to precipitation.

PERIOD OF RECORD.--August 1942 to current year.

EXTREMES FOR PERIOD OF RECORD.--Highest water level, $0.05 \mathrm{ft}$ below land-surface datum, September 26, 1953; lowest,

$12.28 \mathrm{ft}$ below land-surface datum, November 30, 1972.
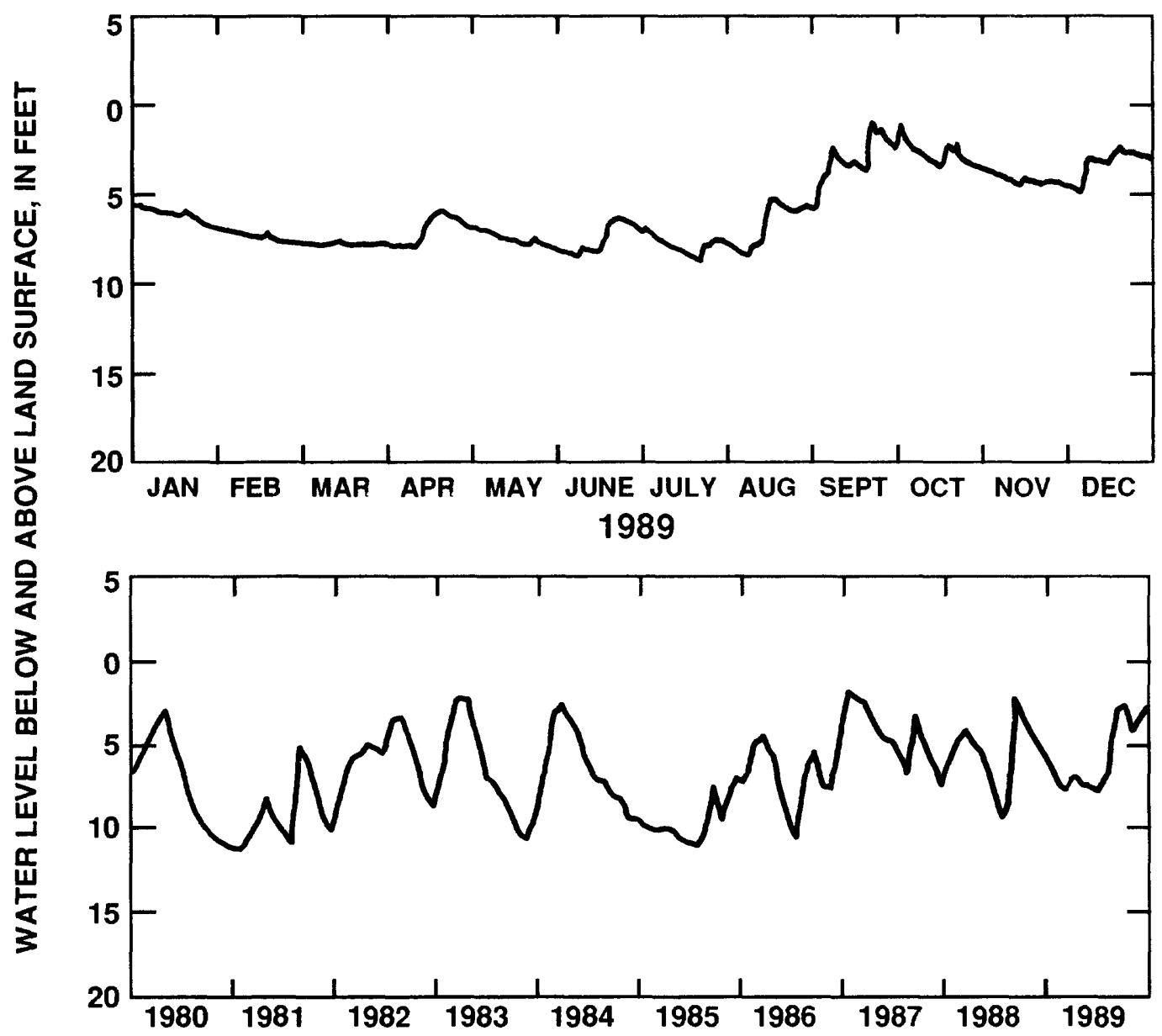

\begin{tabular}{|c|c|c|c|c|c|c|c|c|c|c|c|c|}
\hline 1989 & JAN & FEB & MAR & APR & MAY & JUN & JUL & AUG & SEP & $O C T$ & NOV & DEC \\
\hline $\begin{array}{l}\text { MEAN } \\
\text { MAX } \\
\text { MIN }\end{array}$ & $\begin{array}{l}6.17 \\
6.90 \\
5.58\end{array}$ & $\begin{array}{r}-7.32 \\
7.64 \\
6.93\end{array}$ & $\begin{array}{l}7.66 \\
7.78 \\
7.50\end{array}$ & $\begin{array}{l}6.83 \\
7.81 \\
5.82\end{array}$ & $\begin{array}{l}7.40 \\
7.93 \\
6.81\end{array}$ & $\begin{array}{l}7.38 \\
8.32 \\
6.24\end{array}$ & $\begin{array}{l}7.75 \\
8.58 \\
6.86\end{array}$ & $\begin{array}{l}6.66 \\
8.34 \\
5.13\end{array}$ & $\begin{array}{r}2.93 \\
5.67 \\
.84\end{array}$ & $\begin{array}{l}2.68 \\
3.46 \\
1.03\end{array}$ & $\begin{array}{l}4.08 \\
4.36 \\
3.53\end{array}$ & $\begin{array}{l}3.22 \\
4.70 \\
2.23\end{array}$ \\
\hline CAL $Y$ & 1989 & & MEAN & 5.83 & & $\mathrm{HIGH}$ & .84 & & LOW & 8.58 & & \\
\hline
\end{tabular}

Figure 18.--Water level in observation well 35P094, Chatham County. 
315906081011204 Local number, 37P116.

LOCATION.--Lat 31 $59^{\prime} 06^{\prime \prime}$, long $81^{\circ} 01^{\prime} 12^{\prime \prime}$, Hydrologic Unit $03060204,1300 \mathrm{ft}$ southeast of University of Georgia Skidaway Institute.

Owner: Georgia Geologic Survey, Skidaway Institute test well 4.

AQUIFER.--Surficial (sand of Miocene and post Miocene age).

WELL CHARACTERISTICS.--Drilled observation well, diameter 6 in., depth $85 \mathrm{ft}$, cased to $70 \mathrm{ft}$, screen to $85 \mathrm{ft}$. DATUM.--Altitude of land-surface datum is $10 \mathrm{ft}$.

Measuring point: Top of recorder shelf, $3.8 \mathrm{ft}$ above land-surface datum.

REMARKS.--Water levels for periods of missing record, January 18-25, February 27 to March 1, and July 6-16, were

estimated.

PERIOD OF RECORD.--January 11, 1984 to current year.

EXTREMES FOR PERIOD OF RECORD.--Highest water level, $7.19 \mathrm{ft}$ below land-surface datum, October 31,1985 ; lowest, $9.03 \mathrm{ft}$ below land-surface datum, December 6, 1989.

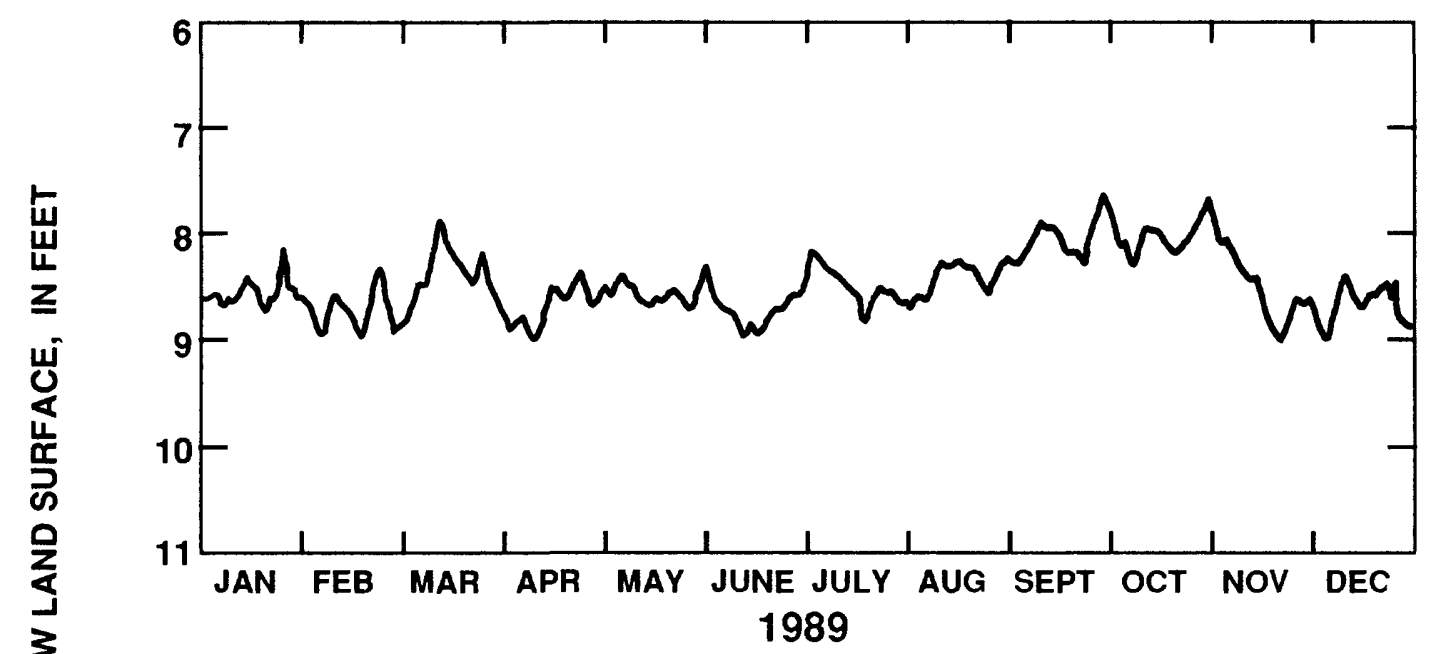

\begin{tabular}{|c|c|c|c|c|c|c|c|c|c|c|c|c|}
\hline 1989 & JAN & FEB & MAR & APR & MAY & JUN & JUL & AUG & SEP & OCT & NOV & DEC \\
\hline $\begin{array}{l}\text { MEAN } \\
\text { MAX } \\
\text { MIN }\end{array}$ & $\begin{array}{l}8.57 \\
8.75 \\
8.14\end{array}$ & $\begin{array}{l}8.74 \\
8.98 \\
8.33\end{array}$ & $\begin{array}{l}8.39 \\
8.84 \\
7.92\end{array}$ & $\begin{array}{l}8.68 \\
9.00 \\
8.37\end{array}$ & $\begin{array}{l}8.59 \\
8.76 \\
8.36\end{array}$ & $\begin{array}{l}8.74 \\
8.96 \\
8.42\end{array}$ & $\begin{array}{l}8.50 \\
8.83 \\
8.17\end{array}$ & $\begin{array}{l}8.44 \\
8.74 \\
8.26\end{array}$ & $\begin{array}{l}8.07 \\
8.31 \\
7.66\end{array}$ & $\begin{array}{l}8.05 \\
8.30 \\
7.70\end{array}$ & $\begin{array}{l}8.50 \\
9.02 \\
7.83\end{array}$ & $\begin{array}{l}8.67 \\
9.03 \\
8.41\end{array}$ \\
\hline
\end{tabular}

CAL YR 1989

MEAN 8.49

HIGH 7.66

LOW 9.03

Figure 19.--Water level in observation well 37P116, Chatham County. 
321240081411502 Local number, 32R003.

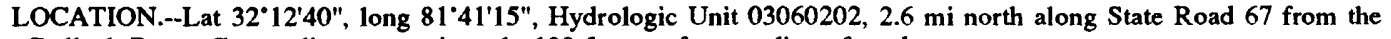
Bulloch-Bryan County line, approximately $100 \mathrm{ft}$ east of center line of road.

Owner: Georgia Geologic Survey, Bulloch South test well 2.

AQUIFER.--Surficial (sand of Miocene and post Miocene age).

WELL CHARACTERISTICS.--Drilled observation well, diameter $6 \mathrm{in}$., depth $155 \mathrm{ft}$, cased to $134 \mathrm{ft}$, screen to $155 \mathrm{ft}$.

DATUM.--Altitude of land-surface datum is $120 \mathrm{ft}$.

Measuring point: Top of recorder shelf, $3.0 \mathrm{ft}$ above land-surface datum.

REMARKS,--Well sounded August 1982.

PERIOD OF RECORD.--February 24, 1983 to current year.

EXTREMES FOR PERIOD OF RECORD.--Highest water level, $8.40 \mathrm{ft}$ below land-surface datum, March 26,$1983 ;$ lowest,

$15.27 \mathrm{ft}$ below land-surface datum, November 14, 1983.

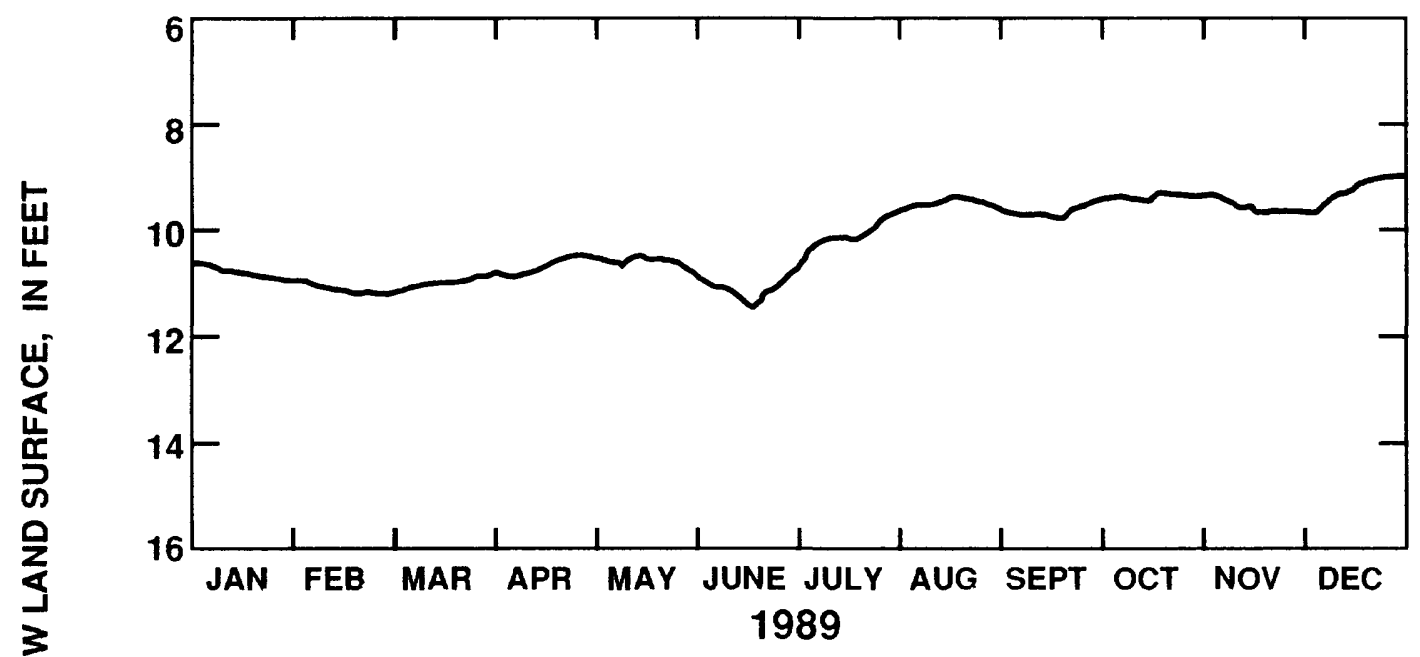

푬

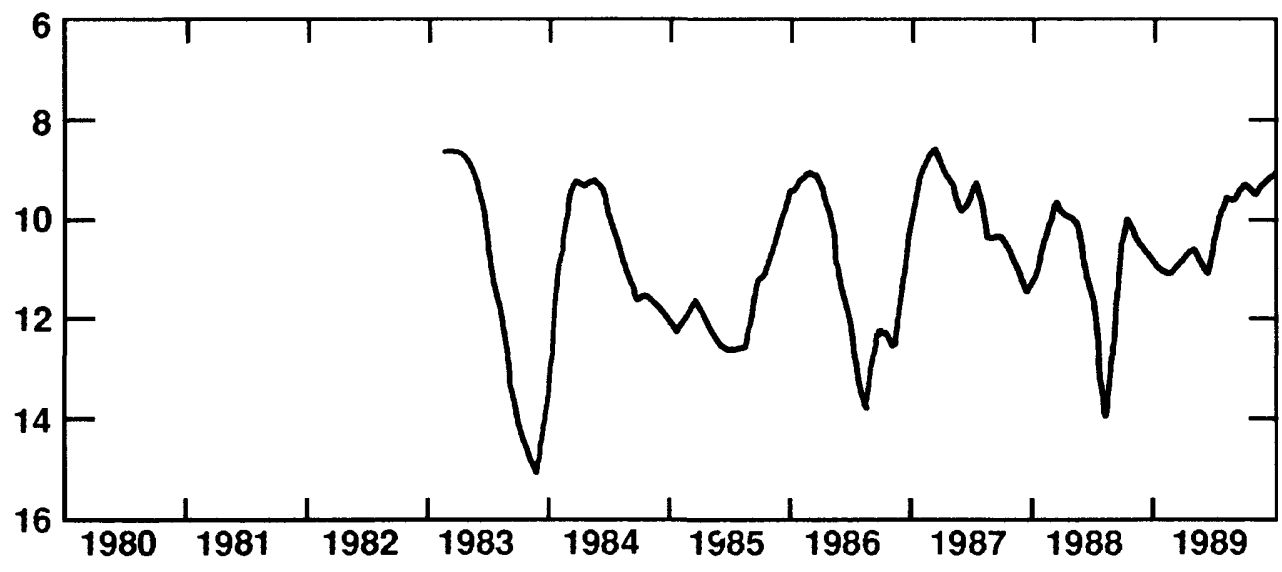

\begin{tabular}{|c|c|c|c|c|c|c|c|c|c|c|c|c|}
\hline 1989 & JAN & FEB & MAR & APR & MAY & JUN & JUL & AUG & SEP & OCT & NOV & DEC \\
\hline $\begin{array}{l}\text { MEAN } \\
\text { MAX } \\
\text { MIN }\end{array}$ & $\begin{array}{l}10.83 \\
11.00 \\
10.65\end{array}$ & $\begin{array}{l}11.13 \\
11.22 \\
10.99\end{array}$ & $\begin{array}{l}10.97 \\
11.20 \\
10.80\end{array}$ & $\begin{array}{l}10.67 \\
10.87 \\
10.49\end{array}$ & $\begin{array}{l}10.56 \\
10.82 \\
10.45\end{array}$ & $\begin{array}{l}11.08 \\
11.44 \\
10.73\end{array}$ & $\begin{array}{r}10.10 \\
10.64 \\
9.67\end{array}$ & $\begin{array}{l}9.46 \\
9.65 \\
9.34\end{array}$ & $\begin{array}{l}9.62 \\
9.78 \\
9.40\end{array}$ & $\begin{array}{l}9.32 \\
9.42 \\
9.24\end{array}$ & $\begin{array}{l}9.50 \\
9.61 \\
9.29\end{array}$ & $\begin{array}{l}9.24 \\
9.62 \\
8.94\end{array}$ \\
\hline CAL Y & 1989 & & MEAN & 10.20 & & HIGH & 8.94 & & LOW & 11.44 & & \\
\hline
\end{tabular}

Figure 20.--Water level in observation well 32R003, Bulloch County. 
310901081284403 Local number, 34H438.

LOCATION.--Lat $31^{\circ} 09^{\prime} 01^{\prime \prime}$, long $81^{\circ} 28^{\prime} 44^{\prime \prime}$, Hydrologic Unit 03070203 , easternmost of three observation wells at the north end of Coffin Park, near the intersection of U.S. Highway 17 and U.S. Highway 25, in Brunswick.

Owner: Georgia Geologic Survey, Coffin Park test well 3.

AQUIFER.--Surficial (sand of Miocene and post Miocene age).

WELL CHARACTERISTICS.--Drilled observation well, diameter $6 \mathrm{in}$., depth $202 \mathrm{ft}$, cased to $192 \mathrm{ft}$, screen to $202 \mathrm{ft}$.

DATUM.--Altitude of land-surface datum is $7 \mathrm{ft}$.

Measuring point: Top of recorder shelf, $3.0 \mathrm{ft}$ above land-surface datum.

REMARKS.--None.

PERIOD OF RECORD.--November 30, 1983 to current year.

EXTREMES FOR PERIOD OF RECORD.--Highest water level, $3.79 \mathrm{ft}$ below land-surface datum, January 4, 1985; lowest, $7.93 \mathrm{ft}$ below land-surface datum, August 4, 1986.

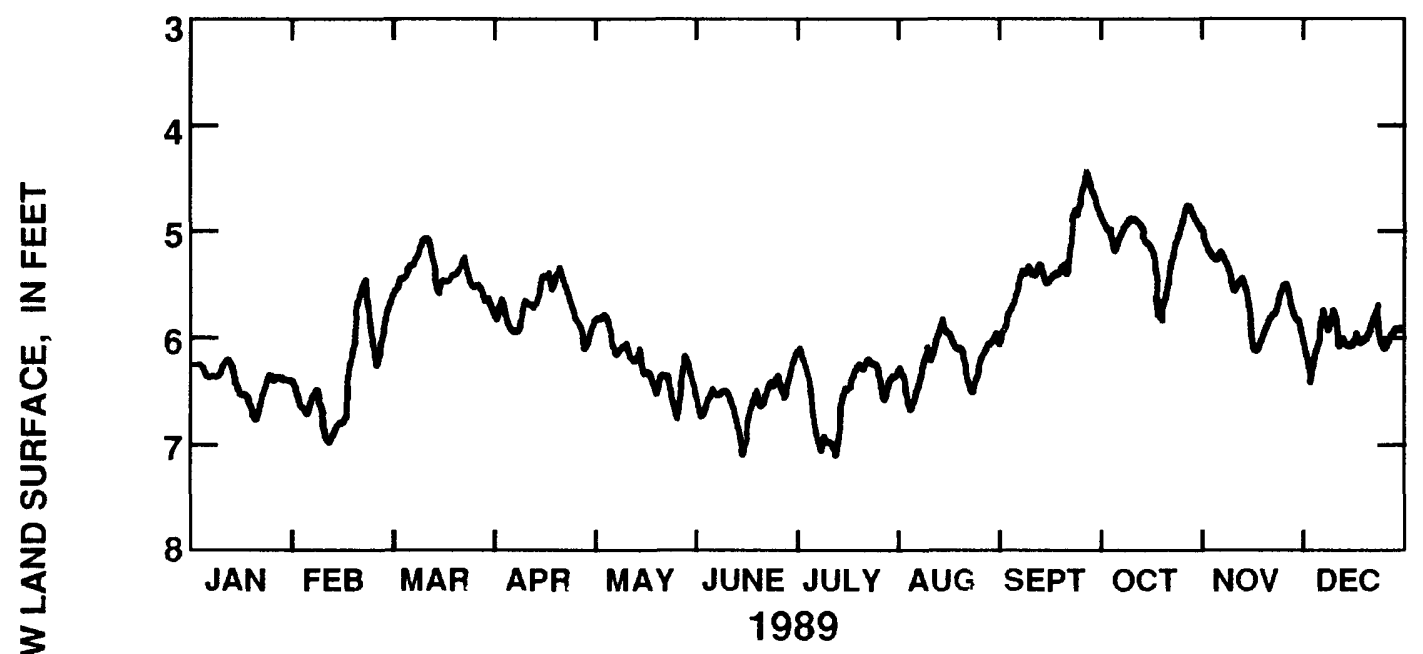

罳

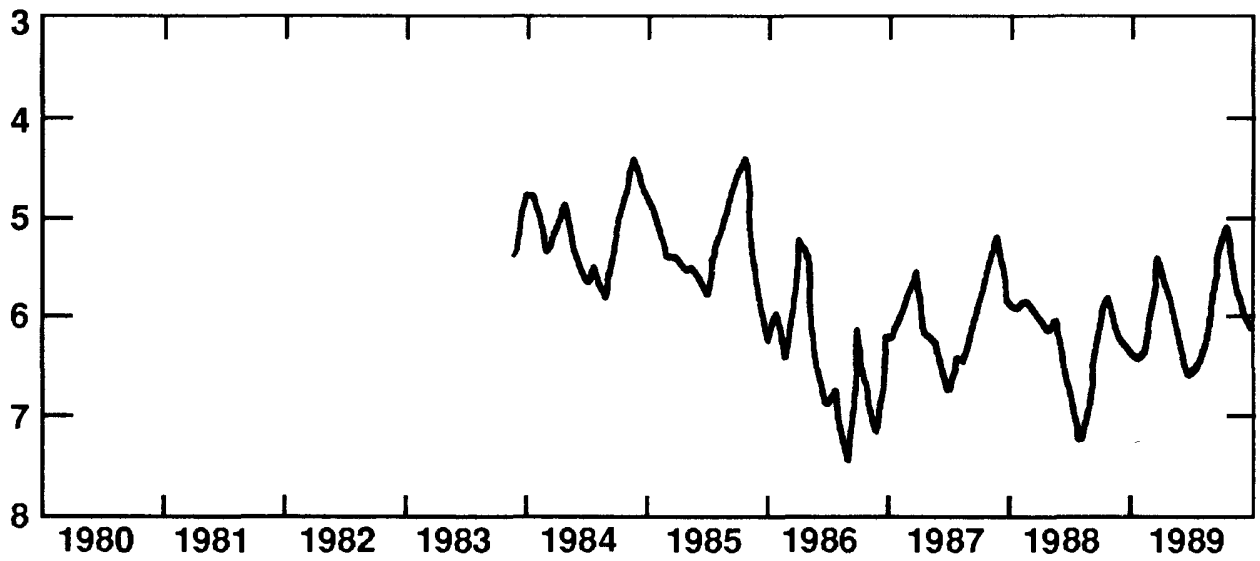

\begin{tabular}{|c|c|c|c|c|c|c|c|c|c|c|}
\hline 1989 & JAN & FEB & MAR & APR & MAY & JUN & JUL & AUG & SEP & OCT \\
\hline $\begin{array}{l}\text { MEAN } \\
\text { MAX } \\
\text { MIN }\end{array}$ & $\begin{array}{l}6.43 \\
6.79 \\
6.21\end{array}$ & $\begin{array}{l}6.38 \\
6.99 \\
5.46\end{array}$ & $\begin{array}{l}5.41 \\
5.66 \\
5.08\end{array}$ & $\begin{array}{l}5.71 \\
6.12 \\
5.35\end{array}$ & $\begin{array}{l}6.21 \\
6.78 \\
5.79\end{array}$ & $\begin{array}{l}6.60 \\
7.11 \\
6.36\end{array}$ & $\begin{array}{l}6.52 \\
7.10 \\
6.12\end{array}$ & $\begin{array}{l}6.24 \\
6.70 \\
5.85\end{array}$ & $\begin{array}{l}5.34 \\
6.08 \\
4.47\end{array}$ & $\begin{array}{l}5.09 \\
5.85 \\
4.73\end{array}$ \\
\hline CAL YF & 1989 & & MEAN & 5.96 & & $\mathrm{HIGH}$ & 4.47 & & LOW & 7.11 \\
\hline
\end{tabular}


In the Jesup, Wayne County area, water-level fluctuations in the surficial aquifer reflect changes in precipitation and nearby pumping (Clarke and others, 1990, p. 26). The mean water level in well 32L017 (fig. 22) was about the same in 1989 as in 1988, leveling-off the general downward trend since monitoring began in 1984.

\section{Upper Brunswick Aquifer}

Water levels in the upper Brunswick aquifer are monitored in three wells, all of which are included in this report (figs. 23-26). Near pumping centers of the Floridan aquifer system, the water level in the upper Brunswick aquifer responds to pumping from the Upper Floridan due to hydraulic connection between the aquifers (Clarke and others, 1990, p. 28). Near outcrop areas, the water level primarily responds to seasonal climatic changes, although the water level also is affected by regional pumping from the Floridan aquifer system.

The upper Brunswick aquifer crops out in Bulloch County and the water level in the aquifer in this area is influenced by both changes in recharge rate and by pumping from the Upper Floridan aquifer. These fluctuations are illustrated by the hydrograph for well 31 009 (fig. 24). The annual-mean water level in well 31 U009 was $0.2 \mathrm{ft}$ higher in 1989 than in 1988, leveling-off a general downward trend since monitoring began in 1983.

In the Wayne and Glynn County areas, the water level in the upper Brunswick aquifer is affected by nearby pumping. During 1988-89, the water level in well 32L016 near Jesup (fig. 25) and well 34 H437 near Brunswick (fig. 26) continued a downward trend similar to that in the underlying Upper Floridan aquifer. The mean water levels in the two wells were $0.7 \mathrm{ft}$ lower in 1989 than in 1988, and a record low was measured in well 32L016 in December. This decline corresponded to a downward trend in the Upper Floridan aquifer. Although water levels were lower in 1989 than in 1988, the rate of decline has diminished.

\section{Floridan Aquifer System}

Water levels in the Floridan aquifer system are monitored in 59 wells, records from 32 are included in this report (fig. 27). In most of the area, the Floridan aquifer is comprised of the upper Floridan aquifer and the lower Floridan aquifer. In and near outcrop areas, water levels in wells tapping the Floridan aquifer system fluctuate seasonally in response to changes in recharge rate and pumping. Near the coast, where the aquifer is deeply buried, water levels respond primarily to pumping, and fluctuations related to recharge are less pronounced. In Georgia, about $655 \mathrm{Mgal} / \mathrm{d}$ is pumped from the Floridan aquifer system, mostly for industrial and irrigation purposes (Pierce and Kundell, 1990).

\section{Upper Floridan aquifer}

Water-level fluctuations and trends in the Upper Floridan aquifer are monitored in 53 wells, 30 of which are included in this report (fig. 27). The area underlain by the Upper Floridan aquifer is divided into four hydrologic areas for discussion of water-level fluctuations and trends: (1) the southwest area, (2) the southcentral area, (3) the east-central area, and (4) the coastal area (fig. 27). 
313253081433504 Local number, 32L017.

LOCATION.--Lat $31^{\circ} 32^{\prime} 52^{\prime \prime}$, long $81^{\circ} 43^{\prime} 36^{\prime \prime}$, Hydrologic Unit 03070106, easternmost of three recorder wells, $0.8 \mathrm{mi}$ north of Gardi Road, $4.3 \mathrm{mi}$ east of Gardi.

Owner: Georgia Geologic Survey, Gardi test well 3.

AQUIFER.--Surficial (sand of Miocene and post Miocene age).

WELL CHARACTERISTICS.--Drilled observation well, diameter $4 \mathrm{in}$., depth $215 \mathrm{ft}$, cased to $200 \mathrm{ft}$, screen to $215 \mathrm{ft}$.

DATUM.--Altitude of land-surface datum is $74 \mathrm{ft}$.

Measuring point: Top of recorder shelf, $4.0 \mathrm{ft}$ above land-surface datum.

REMARKS.--None.

PERIOD OF RECORD.--June 16, 1983 to current year.

EXTREMES FOR PERIOD OF RECORD.--Highest water level, $37.85 \mathrm{ft}$ below land-surface datum, April 16, 1984; lowest,

$42.47 \mathrm{ft}$ below land-surface datum, August 27, 1988.
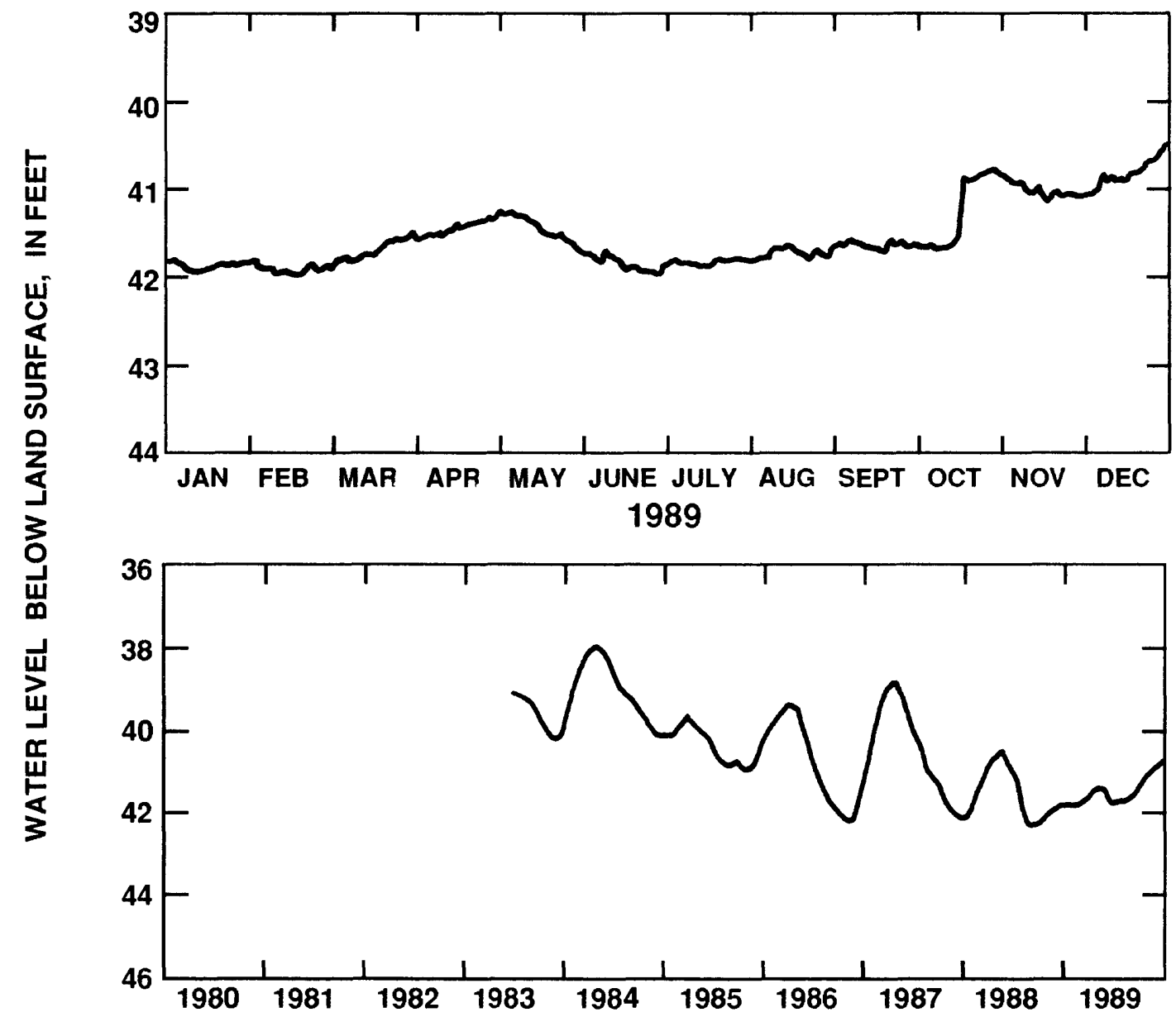

\begin{tabular}{|c|c|c|c|c|c|c|c|c|c|c|c|c|}
\hline 1989 & JAN & FEB & MAR & APR & MAY & JUN & JUL & $\mathbf{A U G}$ & SEP & OCT & NOV & DEC \\
\hline $\begin{array}{l}\text { MEAN } \\
\text { MAX } \\
\text { MIN }\end{array}$ & $\begin{array}{l}41.85 \\
41.93 \\
41.77\end{array}$ & $\begin{array}{l}41.89 \\
41.96 \\
41.78\end{array}$ & $\begin{array}{l}41.68 \\
41.89 \\
41.47\end{array}$ & $\begin{array}{l}41.44 \\
41.58 \\
41.31\end{array}$ & $\begin{array}{l}41.43 \\
41.70 \\
41.23\end{array}$ & $\begin{array}{l}41.85 \\
41.98 \\
41.70\end{array}$ & $\begin{array}{l}41.83 \\
41.89 \\
41.79\end{array}$ & $\begin{array}{l}41.75 \\
41.84 \\
41.64\end{array}$ & $\begin{array}{l}41.66 \\
41.74 \\
41.59\end{array}$ & $\begin{array}{l}41.31 \\
41.70 \\
40.80\end{array}$ & $\begin{array}{l}41.03 \\
41.16 \\
40.85\end{array}$ & $\begin{array}{l}40.89 \\
41.12 \\
40.61\end{array}$ \\
\hline CAL Y & 1989 & & MEAN & 41.55 & & HIGH & 40.61 & & LOW & 41.98 & & \\
\hline
\end{tabular}

Figure 22.--Water level in observation well 32L017, Wayne County. 


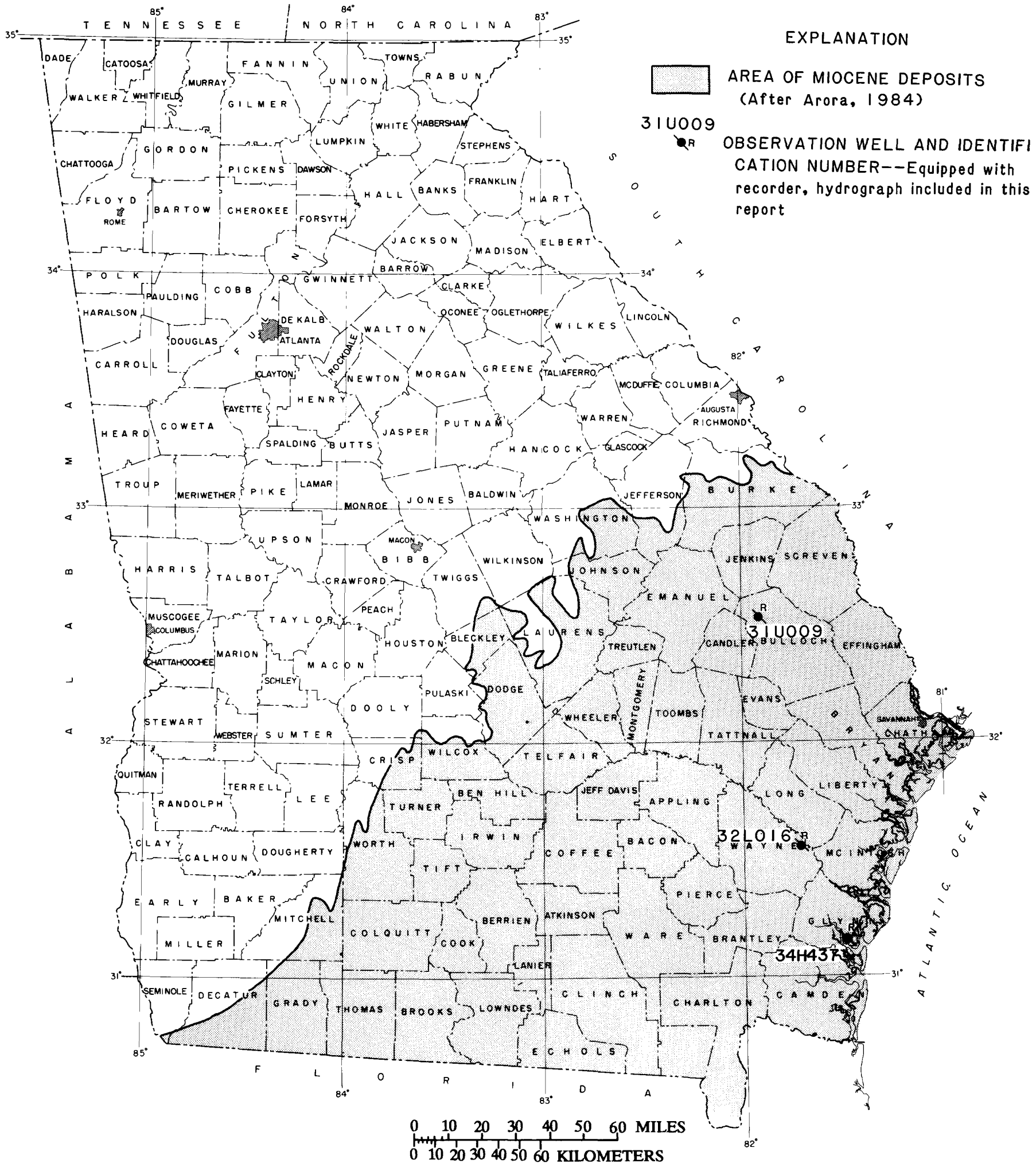

Figure 23.--Locations of observation wells completed in the upper Brunswick aquifer. 
323123081511602 Local number, $31 \mathrm{U} 009$.

LOCATION.--Lat $32^{\circ} 31^{\prime} 23^{\prime \prime}$, long $81^{\circ} 51^{\prime} 16^{\prime \prime}$, Hydrologic Unit 03060202 , in roadside park on west side of Hopeulikit community, U.S. Highways 25 and 80 .

Owner: Georgia Geologic Survey, Hopeulikit test well 2.

AQUIFER.--Upper Brunswick.

WELL CHARACTERISTICS.--Drilled observation well, diameter 6 in., depth $210 \mathrm{ft}$, cased to $160 \mathrm{ft}$, screen to $210 \mathrm{ft}$.

DATUM.--Altitude of land-surface datum is $205 \mathrm{ft}$.

Measuring point: Top of recorder shelf, $3.0 \mathrm{ft}$ above land-surface datum.

REMARKS.--Well sounded August 1982.

PERIOD OF RECORD.--October 1982 to current year.

EXTREMES FOR PERIOD OF RECORD,--Highest water level, $70.77 \mathrm{ft}$ below land-surface datum, April 24,1983 ; lowest,

78.87 ft below land-surface datum, August 4, 1986.
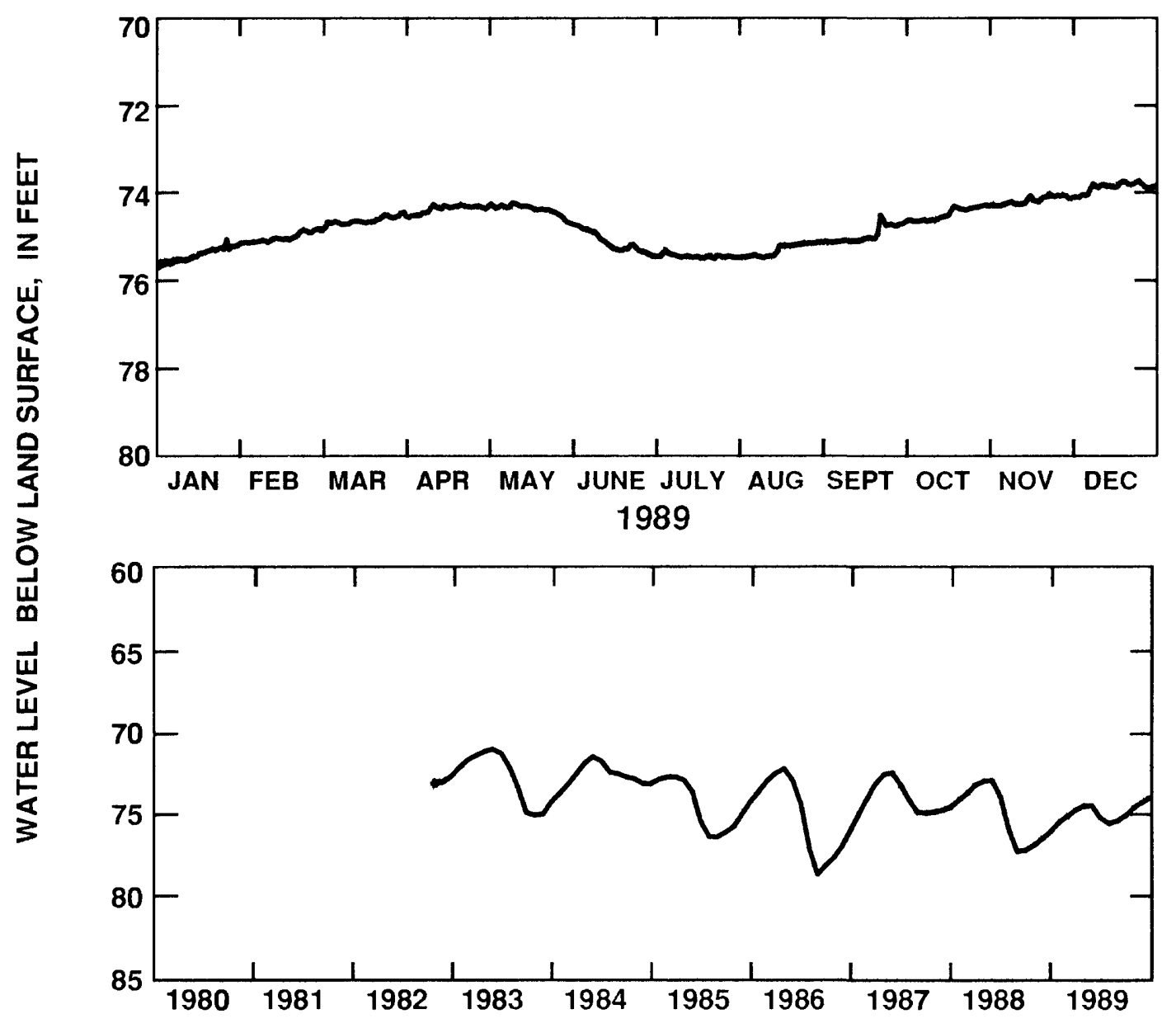

\begin{tabular}{|c|c|c|c|c|c|c|c|c|c|c|c|c|}
\hline 1989 & JAN & FEB & MAR & APR & MAY & JUN & JUL & AUG & SEP & OCT & NOV & DEC \\
\hline MEAN & 75.41 & 75.03 & 74.65 & 74.38 & 74.39 & 75.14 & 75.47 & 75.33 & 74.99 & 74.50 & 74.19 & 73.90 \\
\hline MAX & 75.64 & 75.16 & 74.87 & 74.57 & 74.71 & 75.46 & 75.52 & 75.50 & 75.15 & 74.69 & 74.31 & 74.15 \\
\hline MIN & 75.08 & 74.84 & 74.46 & 74.28 & 74.24 & 74.74 & 75.33 & 75.15 & 74.52 & 74.30 & 74.04 & 73.75 \\
\hline CAL YR & 1989 & & MEAN & 74.78 & & HIGH & 73.75 & & LOW & 75.64 & & \\
\hline
\end{tabular}

Figure 24.--Water level in observation well 310009 , Bulloch County. 
313253081433503 , Local number, 32L016.

LOCATION.--Lat 31 $32^{\prime} 52^{\prime \prime}$, long 81 43'36", Hydrologic Unit 03070106 , middle well of three recorder wells, 0.8 mi north of Gardi Road, on right side of dirt road, $4.3 \mathrm{mi}$ east of Gardi.

Owner: Georgia Geologic Survey, Gardi test well 2.

AQUIFER.--Upper Brunswick.

WELL CHARACTERISTICS.--Drilled observation well, diameter $4 \mathrm{in}$., depth $340 \mathrm{ft}$, cased to $320 \mathrm{ft}$, screen to $340 \mathrm{ft}$.

DATUM.--Altitude of land-surface datum is $74 \mathrm{ft}$.

Measuring point: Top of recorder shelf, $4.0 \mathrm{ft}$ above land-surface datum.

REMARKS.--Well sounded April 26, 1983.

PERIOD OF RECORD.--June 1983 to current year.

EXTREMES FOR PERIOD OF RECORD.--Highest water level, 49.26 ft below land-surface datum, March 20, 1984; lowest,

$55.10 \mathrm{ft}$ below land-surface datum, December 7, 1989.

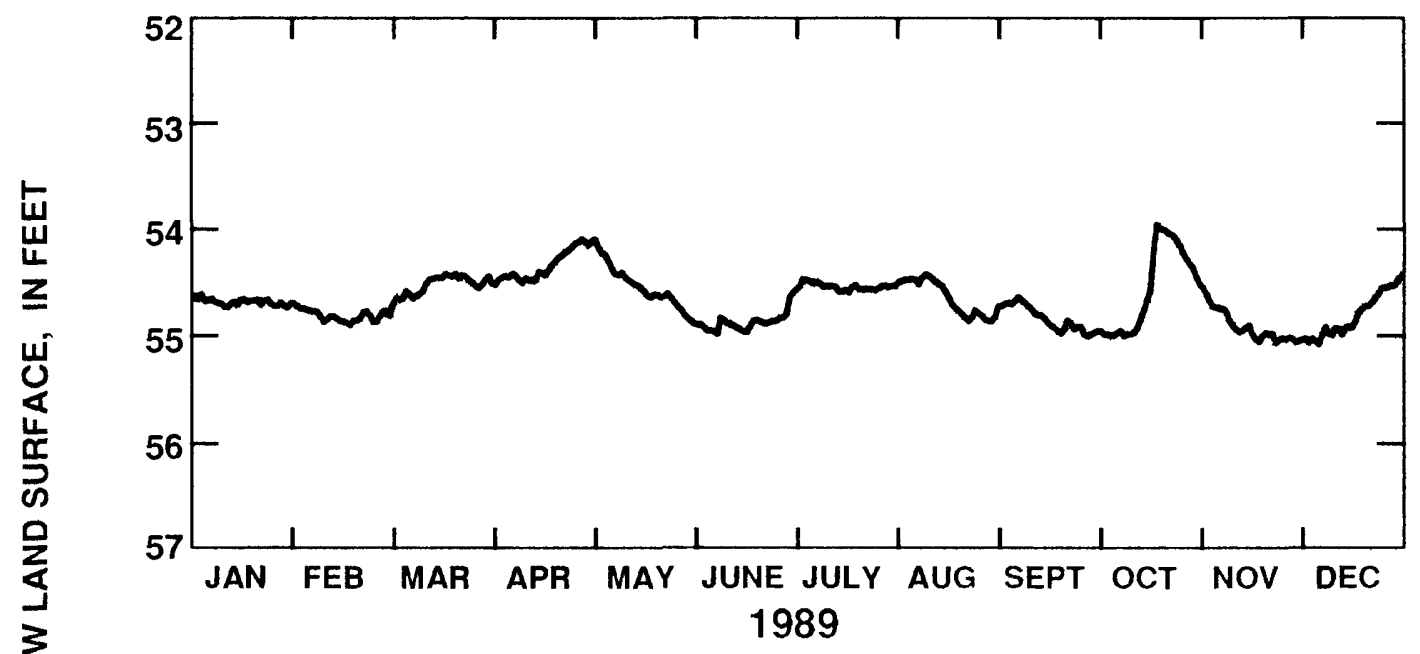

崩

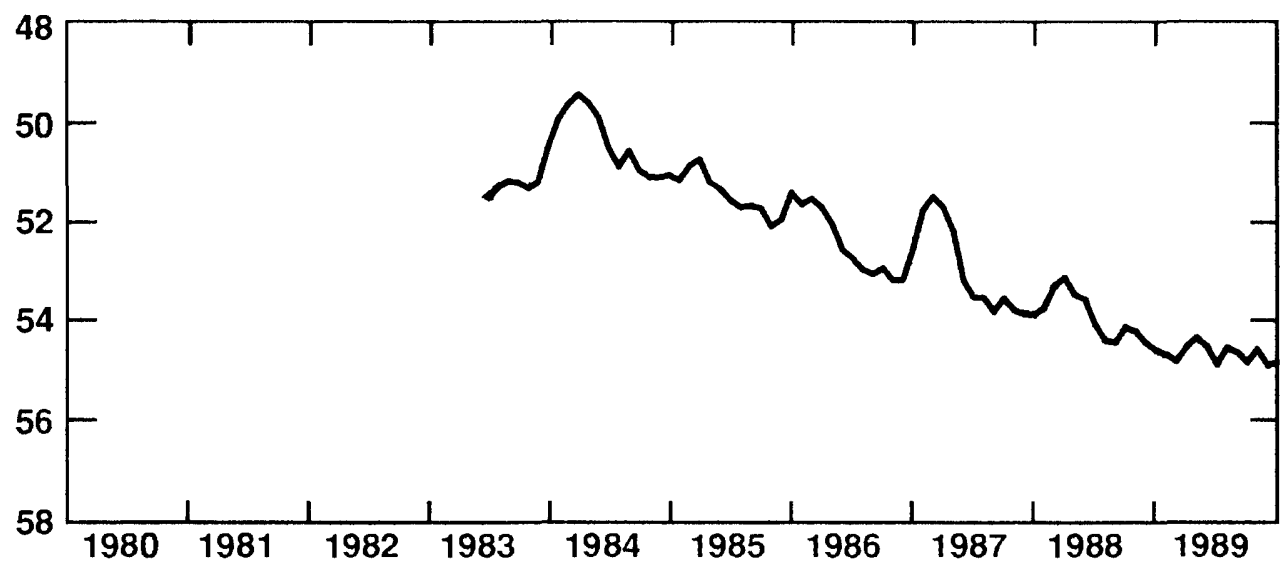

\begin{tabular}{|c|c|c|c|c|c|c|c|c|c|c|c|c|}
\hline 1989 & JAN & FEB & MAR & APR & MAY & JUN & JUL & AUG & SEP & OCT & NOV & DEC \\
\hline $\begin{array}{l}\text { MEAN } \\
\text { MAX } \\
\text { MIN }\end{array}$ & $\begin{array}{l}54.68 \\
54.73 \\
54.61\end{array}$ & $\begin{array}{l}54.82 \\
54.90 \\
54.72\end{array}$ & $\begin{array}{l}54.53 \\
54.81 \\
54.42\end{array}$ & $\begin{array}{l}54.35 \\
54.52 \\
54.09\end{array}$ & $\begin{array}{l}54.52 \\
54.87 \\
54.10\end{array}$ & $\begin{array}{l}54.89 \\
54.99 \\
54.64\end{array}$ & $\begin{array}{l}54.55 \\
54.60 \\
54.48\end{array}$ & $\begin{array}{l}54.64 \\
54.87 \\
54.43\end{array}$ & $\begin{array}{l}54.84 \\
55.02 \\
54.65\end{array}$ & $\begin{array}{l}54.58 \\
55.02 \\
53.96\end{array}$ & $\begin{array}{l}54.91 \\
55.08 \\
54.53\end{array}$ & $\begin{array}{l}54.85 \\
55.10 \\
54.50\end{array}$ \\
\hline CAL Y & 1989 & & MEAN & 54.68 & & $\mathrm{HIGH}$ & 53.96 & & LOW & 55.10 & & \\
\hline
\end{tabular}

Figure 25.--Water level in observation well 32L016, Wayne County. 
310901081284402 Local number, $34 \mathrm{H} 437$.

LOCATION.--Lat $31^{\circ} 09^{\prime} 01^{\prime \prime}$, long $81^{\circ} 28^{\prime} 44^{\prime \prime}$, Hydrologic Unit 03070203 , middle well of three recorder wells at the north end of Coffin Park near the intersection of U.S. Highway 17 and U.S. Highway 25.

Owner: Georgia Geologic Survey, Coffin Park test well 2.

AQUIFER.--Upper Brunswick.

WELL CHARACTERISTICS.--Drilled observation well, diameter 4 in., depth $328 \mathrm{ft}$, cased to $315 \mathrm{ft}$, screen to $328 \mathrm{ft}$.

DATUM.--Altitude of land-surface datum is $7 \mathrm{ft}$.

Measuring point: Top of recorder shelf, $3.0 \mathrm{ft}$ above land-surface datum.

REMARKS.--None.

PERIOD OF RECORD.--January 21, 1984 to current year.

EXTREMES FOR PERIOD OF RECORD.--Highest water level, $2.26 \mathrm{ft}$ above land-surface datum, January 7, 1985; lowest, $7.8 \mathrm{ft}$ below land-surface datum, August 30, 1987.

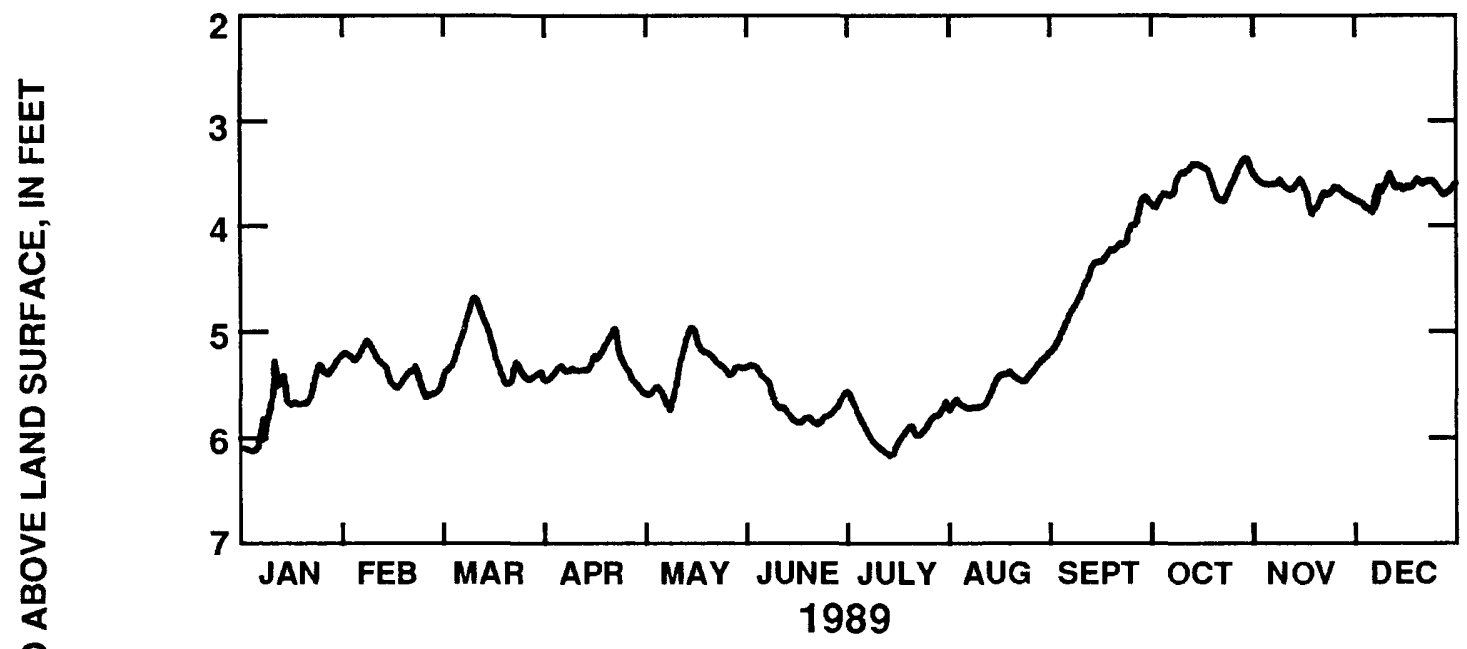

足

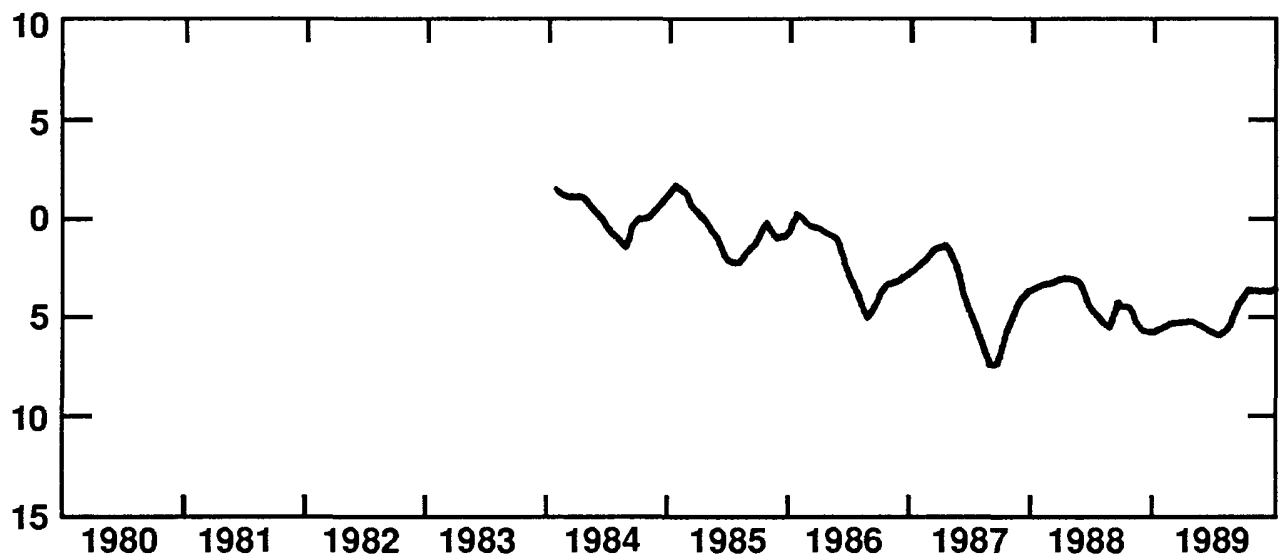

\begin{tabular}{|c|c|c|c|c|c|c|c|c|c|c|}
\hline 1989 & JAN & FEB & MAR & APR & MAY & JUN & JUL & AUG & SEP & OCT \\
\hline $\begin{array}{l}\text { MEAN } \\
\text { MAX } \\
\text { MIN }\end{array}$ & $\begin{array}{l}5.62 \\
6.15 \\
5.21\end{array}$ & $\begin{array}{l}5.37 \\
5.64 \\
5.08\end{array}$ & $\begin{array}{l}5.22 \\
5.58 \\
4.66\end{array}$ & $\begin{array}{l}5.31 \\
5.60 \\
4.96\end{array}$ & $\begin{array}{l}5.37 \\
5.72 \\
4.97\end{array}$ & $\begin{array}{l}5.68 \\
5.90 \\
5.32\end{array}$ & $\begin{array}{l}5.92 \\
6.20 \\
5.55\end{array}$ & $\begin{array}{l}5.53 \\
5.75 \\
5.24\end{array}$ & $\begin{array}{l}4.43 \\
5.19 \\
3.72\end{array}$ & $\begin{array}{l}3.59 \\
3.82 \\
3.34\end{array}$ \\
\hline CAL YR & 1989 & & MEAN & 4.95 & & $\mathrm{HIGH}$ & 3.34 & & LOW & 6.20 \\
\hline
\end{tabular}




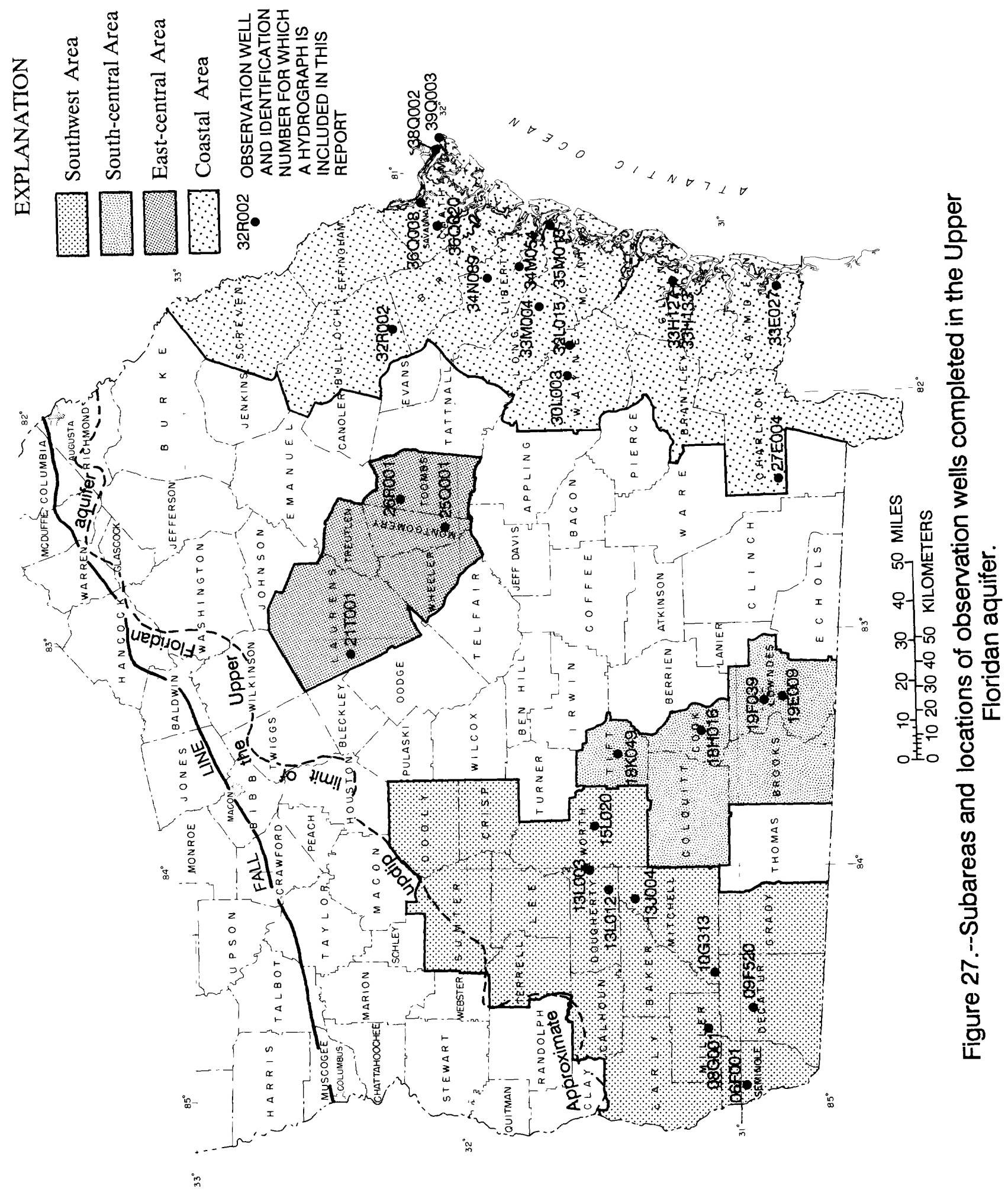




\section{Southwest area}

The water levels in the Upper Floridan aquifer in southwestern Georgia are monitored in 23 wells, records from eight are included in this report (fig. 27). In the southwest area, water levels in wells tapping the aquifer respond to variations in precipitation, evapotranspiration, pumping, and streamflow (Hayes and others, 1983, p. 16). During 1987, an estimated $377 \mathrm{Mgal} / \mathrm{d}$ was withdrawn from aquifers in southwestern Georgia, much of which was from the Upper Floridan aquifer, primarily for irrigation (Trent and others, 1990). This large withdrawal has not produced a discernible cone of depression over most of the area because wells are widely separated, the transmissivity of the aquifer is high, and the volume of water that flows through the aquifer is large. The large withdrawal also has not caused long-term water-level declines over most of the area because pumping is seasonal and recharge is adequate during periods of normal precipitation. Although pumping has not produced a cone of depression or water-level declines over most of the area, in the Sylvester, Worth County area, a cone of depression has developed as a result of local pumping and the less-productive water-bearing characteristics of the aquifer in that area (D.W. Hicks, U.S. Geological Survey, oral commun., 1990).

During November 1989, water levels were measured in 176 wells tapping the Upper Floridan aquifer in the southwest area and a water-level map was constructed (fig. 28). The general configuration of the waterlevel map changed hittle between 1988 and 1989.

The mean water levels in wells 09F520, 08G001, 06F001, and $13 \mathrm{~L} 012$ tapping the Upper Floridan aquifer were from 0.6 to $1.1 \mathrm{ft}$ higher in 1989 than in 1988 (figs. 29-32), reversing a general downward trend since 1984. The four wells are located near the Flint River or its tributaries where the aquifer is semiconfined by a thin overburden and there is some hydraulic connection between the aquifer and surface streams. Abovenormal precipitation during 1989 resulted in decreased pumping and increased recharge to the aquifer, and thus higher water-levels. (See precipitation graph for Albany, figure 8). Away from the Flint River and its tributaries, the aquifer is more confined by thicker overburden and is not well connected to streams or rapidly influenced by precipitation. Water-level fluctuations and trends in these areas are illustrated by the hydrographs for wells 10G313, 13L003, 13J004, and 15L020 (figs. 33-36). The mean water levels in the four wells were from 0.4 to $4.1 \mathrm{ft}$ lower in 1989 than in 1988, continuing a general downward trend since 1984.

\section{South-central area}

The water level in the Upper Floridan aquifer in south-central Georgia is monitored in six wells, records from four are included in this report (figs. 37-40). Water levels in wells tapping the aquifer in this area are affected by precipitation, evapotranspiration, and to a lesser degree, pumping (Krause, 1979). In the Valdosta area, water levels also are affected by streamflow (Krause, 1979). The water level generally is highest during winter and spring rainy seasons, and lowest in the fall. During 1987, an estimated $79 \mathrm{Mgal} / \mathrm{d}$ was withdrawn from aquifers in south-central Georgia (Trent and others, 1990), most of which was from the Upper Floridan aquifer. Of this amount, about $6 \mathrm{Mgal} / \mathrm{d}$ was withdrawn in the Valdosta area.

A general downward trend in the water level in the Upper Floridan aquifer has been observed in two observation wells in Tift and Cook Counties since at least 1977. The mean water levels in well 18K049 in Tift County (fig. 37) and in well $18 \mathrm{H} 016$ in Cook County (fig. 38) were 0.2 and $0.3 \mathrm{ft}$ lower in 1989 than in 1988 respectively. These slight declines represent a contiuation of the general downward water-level trend in the area, but at a reduced rate of decline.

The Upper Floridan aquifer receives recharge from the Withlacoochee River north of Valdosta where water from the river flows directly into sinkholes and cave openings in the aquifer (Krause, 1979). In this area, increased precipitation and streamflow in winter and early spring results in high water levels. During most years, decreased precipitation and increased evapotranspiration in the summer results in low streamflow and correspondingly low water levels. However, above normal precipitation in the summer of 1989 resulted in increased recharge to the aquifer and a corresponding rise in water level. This water-level rise is illustrated on the hydrographs for wells 19E009 and 19F039 (figs. 39 and 40), where the mean water levels were 1.2 and $2.0 \mathrm{ft}$ higher in 1989 than in 1988, respectively. Although water levels rose during 1988-89, no trend was apparent. 


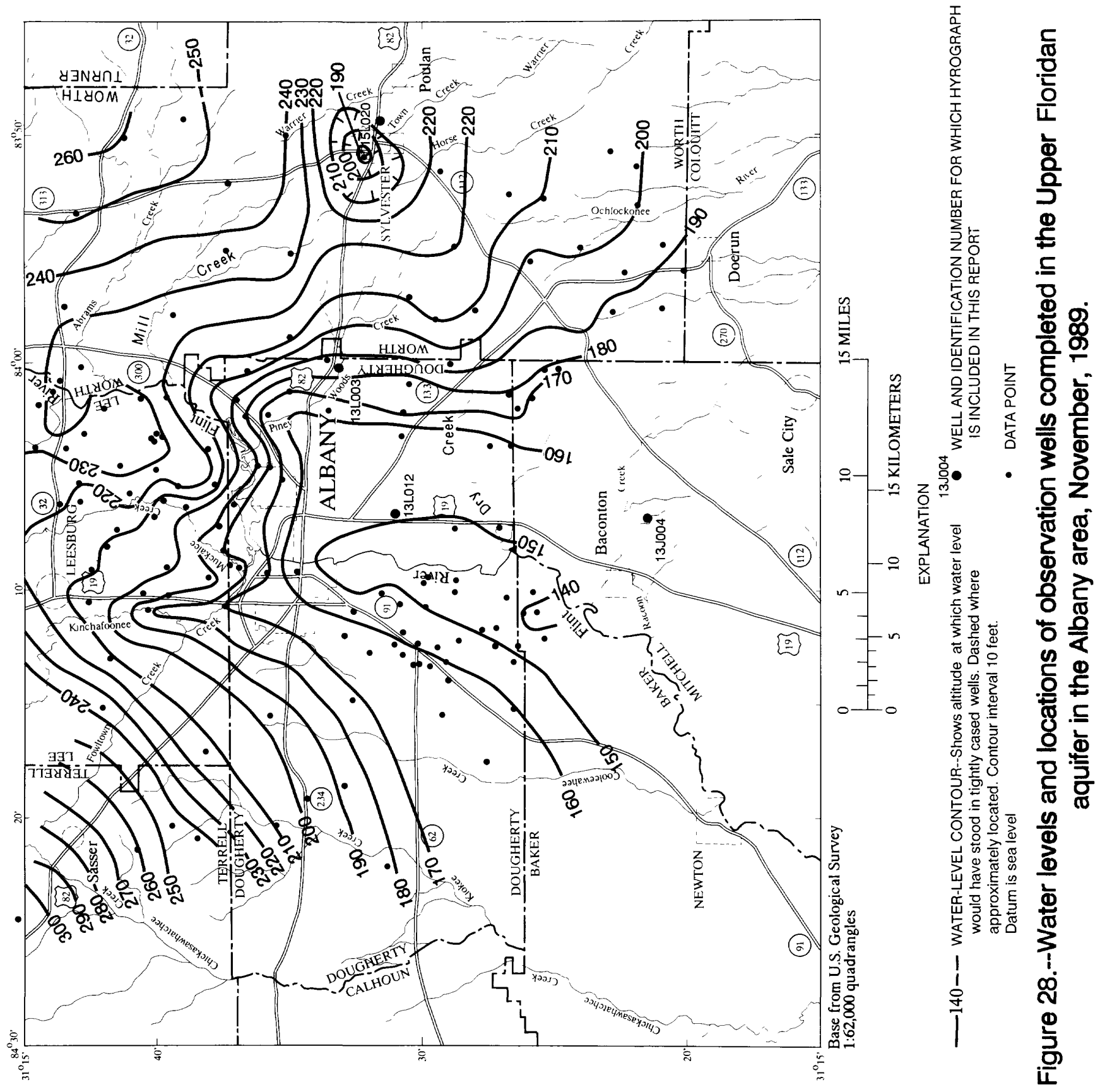


305736084355801 Local number, 09F520.

LOCATION.--Lat 30 $57^{\prime} 42^{\prime \prime}$, long 84 35'46", Hydrologic Unit 03130008, 0.5 mi north of intersection of White's Mill Road and railroad track, $1.0 \mathrm{mi}$ east of U.S. Highway 27 north of Bainbridge.

Owner: Graham Bolton.

AQUIFER.--Upper Floridan aquifer.

WELL CHARACTERISTICS.--Unused irrigation well, diameter $12 \mathrm{in}$., depth $251 \mathrm{ft}$, cased to $130 \mathrm{ft}$, open hole.

DATUM.--Altitude of land-surface datum is $128 \mathrm{ft}$.

Measuring point: Top of recorder shelf, $3.50 \mathrm{ft}$ above land-surface datum.

REMARKS.--This well is about $15 \mathrm{ft}$ from an irrigation well.

PERIOD OF RECORD.--June 1969 to current year.

EXTREMES FOR PERIOD OF RECORD.--Highest water level, $34.86 \mathrm{ft}$ below land-surface datum, April 15, 1984; lowest,

$54.78 \mathrm{ft}$ below land-surface datum, August 20, 1981.
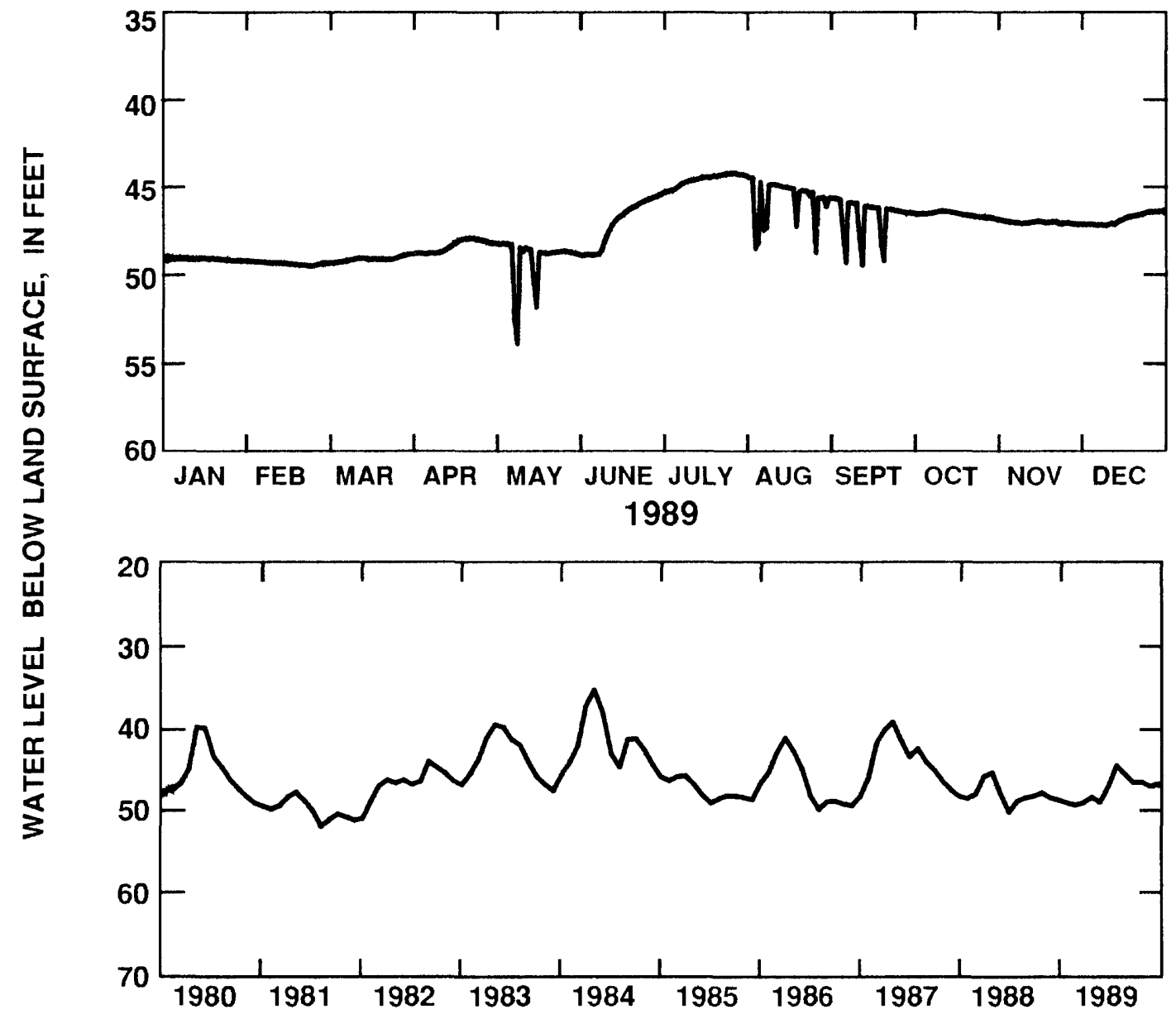

\begin{tabular}{|c|c|c|c|c|c|c|c|c|c|c|c|c|}
\hline 1989 & JAN & FEB & MAR & APR & MAY & JUN & JUL & AUG & SEP & OCT & NOV & DEC \\
\hline $\begin{array}{l}\text { MEAN } \\
\text { MAX } \\
\text { MIN }\end{array}$ & $\begin{array}{l}49.11 \\
49.22\end{array}$ & $\begin{array}{l}49.37 \\
49.51\end{array}$ & $\begin{array}{l}49.12 \\
49.36\end{array}$ & $\begin{array}{l}48.40 \\
48.83\end{array}$ & $\begin{array}{l}49.07 \\
53.99\end{array}$ & $\begin{array}{l}47.14 \\
48.93\end{array}$ & $\begin{array}{l}44.59 \\
45.39\end{array}$ & $\begin{array}{l}45.69 \\
48.82\end{array}$ & $\begin{array}{l}46.69 \\
49.56\end{array}$ & $\begin{array}{l}46.66 \\
46.94\end{array}$ & $\begin{array}{l}47.14 \\
47.26\end{array}$ & $\begin{array}{l}46.97 \\
47.33\end{array}$ \\
\hline MIN & 49.03 & 49.24 & 48.84 & 47.95 & 48.24 & 45.46 & 44.18 & 44.37 & 45.67 & 46.46 & 46.98 & 46.49 \\
\hline AL Y & 1989 & & MEAN & 47.48 & & HIGH & 44.18 & & LOW & 53.99 & & \\
\hline
\end{tabular}

Figure 29.--Water level in observation well 09F520, Decatur County. 
310651084404501 Local number, $08 \mathrm{G001.}$

LOCATION.--Lat 31 $06^{\prime} 51^{\prime \prime}$, long $84^{\circ} 40^{\prime} 45^{\prime \prime}$, Hydrologic Unit $03130010,0.35$ mi east of Boykin on County Road 48, north on dirt road $0.6 \mathrm{mi}$ to dirt road, $0.3 \mathrm{mi}$ east to well on north side of road.

Owner: Viercocken.

AQUIFER.--Upper Floridan aquifer.

WELL CHARACTERISTICS.--Drilled unused irrigation well, diameter $12 \mathrm{in}$., depth $255 \mathrm{ft}$, cased to $130 \mathrm{ft}$, open hole.

DATUM.--Altitude of land-surface datum is $150 \mathrm{ft}$.

Measuring point: Top of recorder shelf, $3.0 \mathrm{ft}$ above land-surface datum.

REMARKS.--None.

PERIOD OF RECORD.--February 1977 to current year.

EXTREMES FOR PERIOD OF RECORD.--Highest water level, $11.18 \mathrm{ft}$ below land-surface datum, April 11, 1984: lowest,

$43.88 \mathrm{ft}$ below land-surface datum, July 17, 1981.
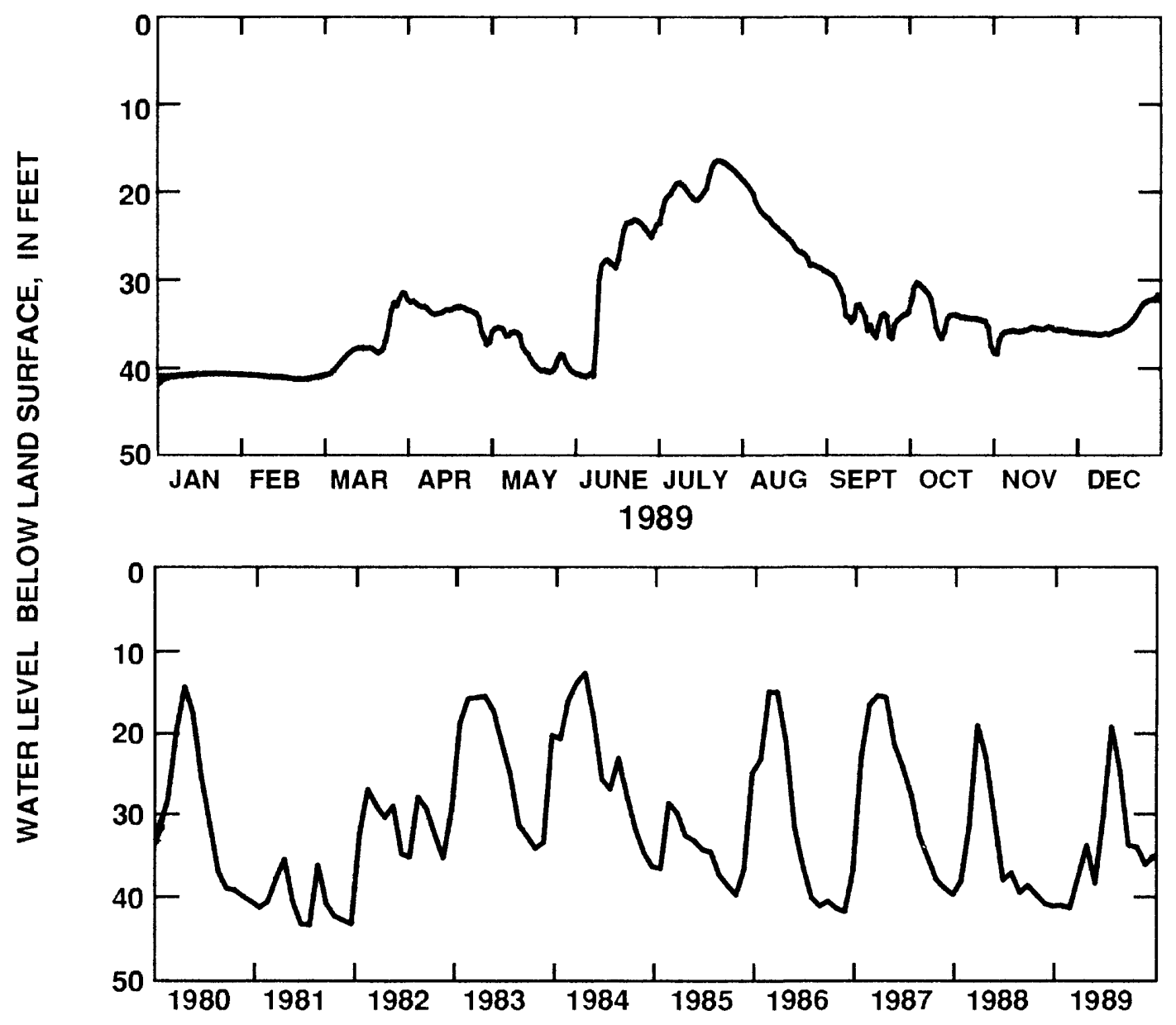

\begin{tabular}{|c|c|c|c|c|c|c|c|c|c|c|c|c|}
\hline 1989 & JAN & FEB & MAR & APR & MAY & JUN & JUL & AUG & SEP & OCT & NOV & DEC \\
\hline $\begin{array}{l}\text { MEAN } \\
\text { MAX } \\
\text { MIN }\end{array}$ & $\begin{array}{l}40.97 \\
41.28 \\
40.83\end{array}$ & $\begin{array}{l}41.23 \\
41.46 \\
40.95\end{array}$ & $\begin{array}{l}37.49 \\
41.06 \\
31.57\end{array}$ & $\begin{array}{l}33.75 \\
37.50 \\
32.36\end{array}$ & $\begin{array}{l}38.29 \\
40.68 \\
35.56\end{array}$ & $\begin{array}{l}30.20 \\
41.17 \\
23.22\end{array}$ & $\begin{array}{l}19.28 \\
23.78 \\
16.47\end{array}$ & $\begin{array}{l}24.55 \\
29.03 \\
18.57\end{array}$ & $\begin{array}{l}33.73 \\
36.84 \\
29.22\end{array}$ & $\begin{array}{l}33.99 \\
37.74 \\
30.46\end{array}$ & $\begin{array}{l}36.08 \\
38.56 \\
35.56\end{array}$ & $\begin{array}{l}35.09 \\
36.43 \\
31.84\end{array}$ \\
\hline CAL Y & 1989 & & MEAN & 33.66 & & $\mathrm{HIGH}$ & 16.47 & & LOW & 41.46 & & \\
\hline
\end{tabular}

Figure 30.--Water level in observation well 08G001, Miller County. 
305356084534601 Local number, 06F001.

LOCATION.--Lat $30^{\circ} 54^{\circ} \mathrm{1}^{\prime \prime}$, long $84^{\circ} 53^{\circ} 40^{\prime \prime}$, Hydrologic Unit $03130004,9.8 \mathrm{mi}$ south of Donalsonville, $1.3 \mathrm{mi}$ west of Ga. Highway 39 on County Road 219, north $0.55 \mathrm{mi}$ on Hebrew Road to dirt road, $0.5 \mathrm{mi}$ east on dirt road.

Owner: Roddenbery Company Farms test well 1.

AQUIFER.--Upper Floridan aquifer.

WELL CHARACTERISTICS.--Drilled observation well, diameter 4 in., depth $150 \mathrm{ft}$, cased to $98.5 \mathrm{ft}$, open hole.

DATUM.--Altitude of land-surface datum is $110 \mathrm{ft}$.

Measuring point: Top of recorder shelf , $3.14 \mathrm{ft}$ above land-surface datum.

REMARKS.--Borehole geophysical survey conducted August 10, 1983. Well pumped and redeveloped August $10,1989$.

Water levels for period of missing record, May 20 to June 18, were estimated.

PERIOD OF RECORD.--March 1979 to July 1982, August 1983 to current year.

EXTREMES FOR PERIOD OF RECORD.--Highest water level, $4.13 \mathrm{ft}$ below land-surface datum, March 8, 1984: lowest,

$35.65 \mathrm{ft}$ below land-surface datum, October $5,1986$.
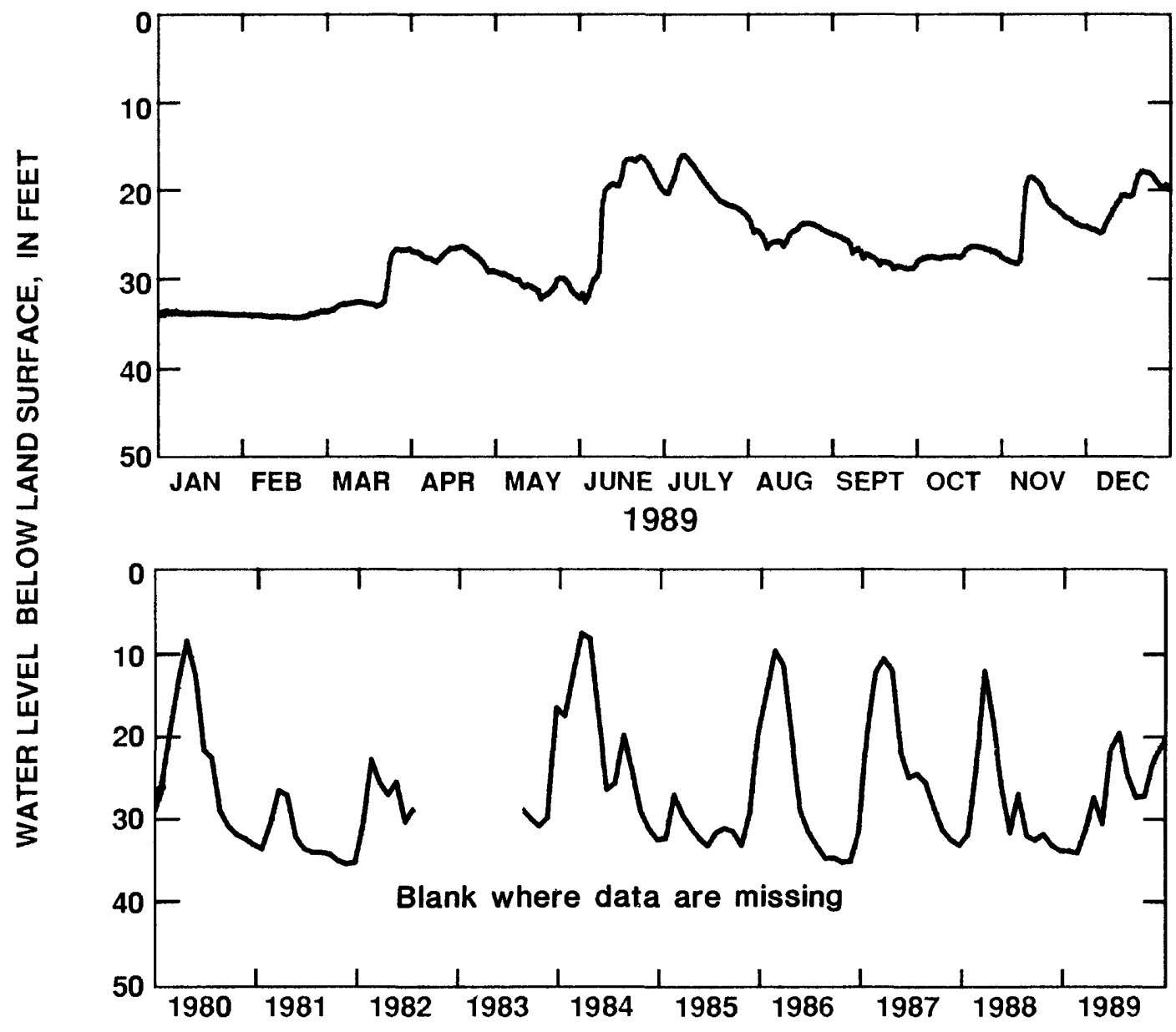

\begin{tabular}{|c|c|c|c|c|c|c|c|c|c|c|c|c|}
\hline 1989 & JAN & FEB & MAR & APR & MAY & JUN & JUL & AUG & SEP & OCT & NOV & DEC \\
\hline $\begin{array}{l}\text { MEAN } \\
\text { MAX } \\
\text { MIN }\end{array}$ & $\begin{array}{l}33.87 \\
34.02 \\
33.67\end{array}$ & $\begin{array}{l}34.10 \\
34.31 \\
33.61\end{array}$ & $\begin{array}{l}31.29 \\
33.65 \\
26.61\end{array}$ & $\begin{array}{l}27.34 \\
29.18 \\
26.33\end{array}$ & $\begin{array}{l}30.55 \\
32.21 \\
29.11\end{array}$ & $\begin{array}{l}21.55 \\
32.56 \\
16.15\end{array}$ & $\begin{array}{l}19.59 \\
22.71 \\
15.99\end{array}$ & $\begin{array}{l}24.77 \\
26.57 \\
23.03\end{array}$ & $\begin{array}{l}27.39 \\
28.87 \\
25.00\end{array}$ & $\begin{array}{l}27.20 \\
28.47 \\
26.33\end{array}$ & $\begin{array}{l}23.22 \\
28.27 \\
18.47\end{array}$ & $\begin{array}{l}21.22 \\
24.86 \\
17.84\end{array}$ \\
\hline AL & & & MEAN & 26.80 & & $\mathrm{HIGH}$ & 15.99 & & LOW & 34.31 & & \\
\hline
\end{tabular}

Figure 31.--Water level in observation well 06F0u1, Seminole County. 
313105084064302 Local number, $13 \mathrm{~L} 012$.

LOCATION.--Lat $31^{\circ} 31^{\prime} 05^{\prime \prime}$, long $84^{\circ} 06^{\prime} 43^{\prime \prime}$, Hydrologic Unit 03130008 , about 6.5 mi southeast of Albany, east of U.S.

Highway 19 on dirt road, 0.1 mi north of School Bus Road.

Owner: U.S. Geological Survey test well 3.

AQUIFER.--Upper Floridan aquifer.

WELL CHARACTERISTICS.--Drilled observation well, diameter 4 in., depth $218 \mathrm{ft}$, cased to $54 \mathrm{ft}$, open hole.

DATUM.--Altitude of land-surface datum is $195 \mathrm{ft}$.

Measuring point: Top of recorder shelf, $3.0 \mathrm{ft}$ above land-surface datum.

REMARKS.--Well pumped and redeveloped August 17, 1988.

PERIOD OF RECORD.--June 1977 to current year.

EXTREMES FOR PERIOD OF RECORD.--Highest water level, $21.92 \mathrm{ft}$ below land-surface datum, March 2, 1979: lowest,

$48.18 \mathrm{ft}$ below land-surface datum, July $1,1981$.

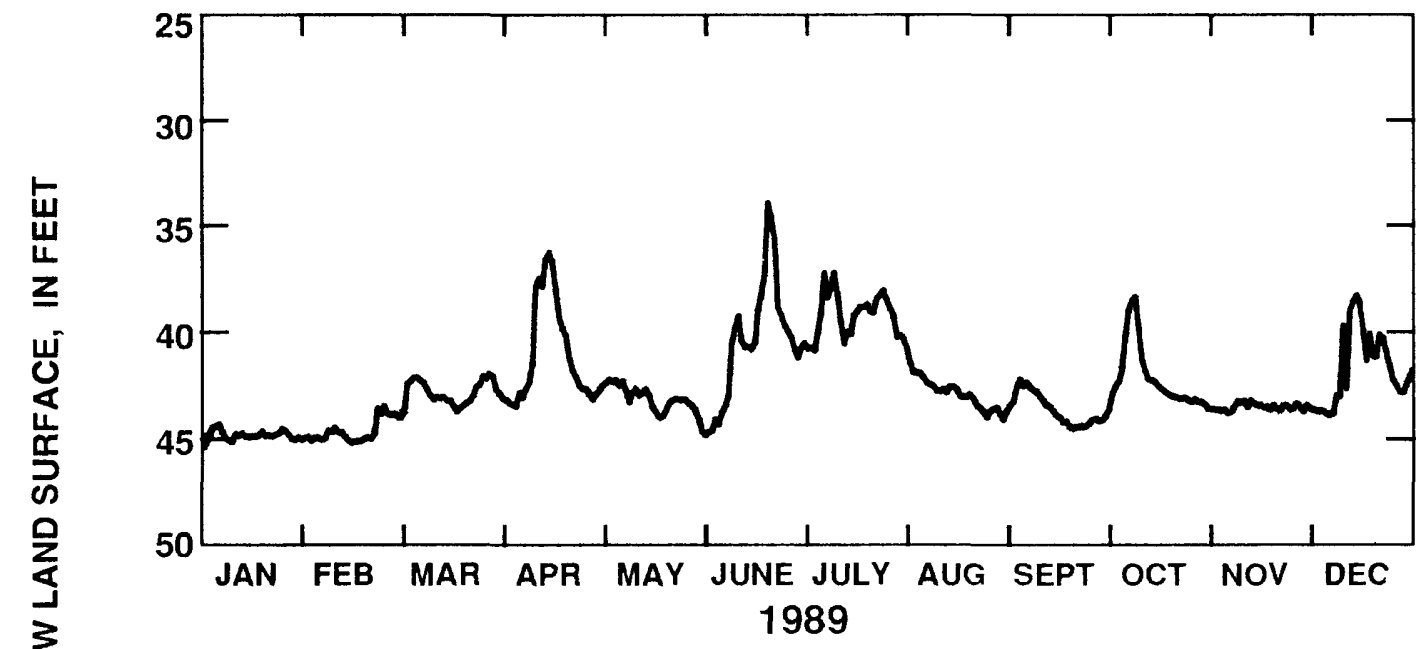

\begin{tabular}{|c|c|c|c|c|c|c|c|c|c|c|c|c|}
\hline 1989 & JAN & FEB & MAR & APR & MAY & JUN & JUL & $A \cup G$ & SEP & OCT & NOV & DEC \\
\hline $\begin{array}{l}\text { MEAN } \\
\text { MAX } \\
\text { MIN }\end{array}$ & $\begin{array}{l}44.80 \\
45.11 \\
44.31\end{array}$ & $\begin{array}{l}44.61 \\
45.16 \\
43.45\end{array}$ & $\begin{array}{l}42.82 \\
43.97 \\
41.94\end{array}$ & $\begin{array}{l}41.09 \\
43.48 \\
36.22\end{array}$ & $\begin{array}{l}43.11 \\
44.67 \\
42.20\end{array}$ & $\begin{array}{l}40.47 \\
44.84 \\
33.89\end{array}$ & $\begin{array}{l}39.19 \\
40.84 \\
37.17\end{array}$ & $\begin{array}{l}42.86 \\
44.14 \\
40.73\end{array}$ & $\begin{array}{r}43.67 \\
44.56 \\
42.23\end{array}$ & $\begin{array}{l}42.23 \\
43.67 \\
38.35\end{array}$ & $\begin{array}{l}43.57 \\
43.84 \\
43.25\end{array}$ & $\begin{array}{l}41.80 \\
43.95 \\
38.32\end{array}$ \\
\hline CAL YF & 1989 & & MEAN & 42.50 & & $\mathrm{HIGH}$ & 33.89 & & LOW & 45.16 & & \\
\hline
\end{tabular}

Figure 32.--Water level in observation well 13L012, Dougherty County. 
310507084262201 Local number, $10 \mathrm{G} 313$.

LOCATION.--Lat $31^{\circ} 05^{\prime} 07^{\prime \prime}$, long $84^{\circ} 26^{\prime} 22^{\prime \prime}$, Hydrologic Unit $03130008,1.95 \mathrm{mi}$ west of Vada off Decatur-Mitchell County line road, $1.0 \mathrm{mi}$ north in pine tree farm.

Owner: Harvey Meinders.

AQUIFER.--Upper Floridan aquifer.

WELL CHARACTERISTICS.--Cable-tooled observation well, diameter $12 \mathrm{in}$., depth $250 \mathrm{ft}$, cased to $87 \mathrm{ft}$, open hole.

DATUM.--Altitude of land-surface datum is $145 \mathrm{ft}$.

Measuring point: Top of recorder shelf, $4.17 \mathrm{ft}$ above land-surface datum.

REMARKS.--None.

PERIOD OF RECORD.--November 1961 to September 1968: April 1976 to current year.

EXTREMES FOR PERIOD OF RECORD.--Highest water leve1, $32.98 \mathrm{ft}$ below land-surface datum, April 9, 1984; lowest, $60.26 \mathrm{ft}$ below land-surface datum, January 1,1982 .
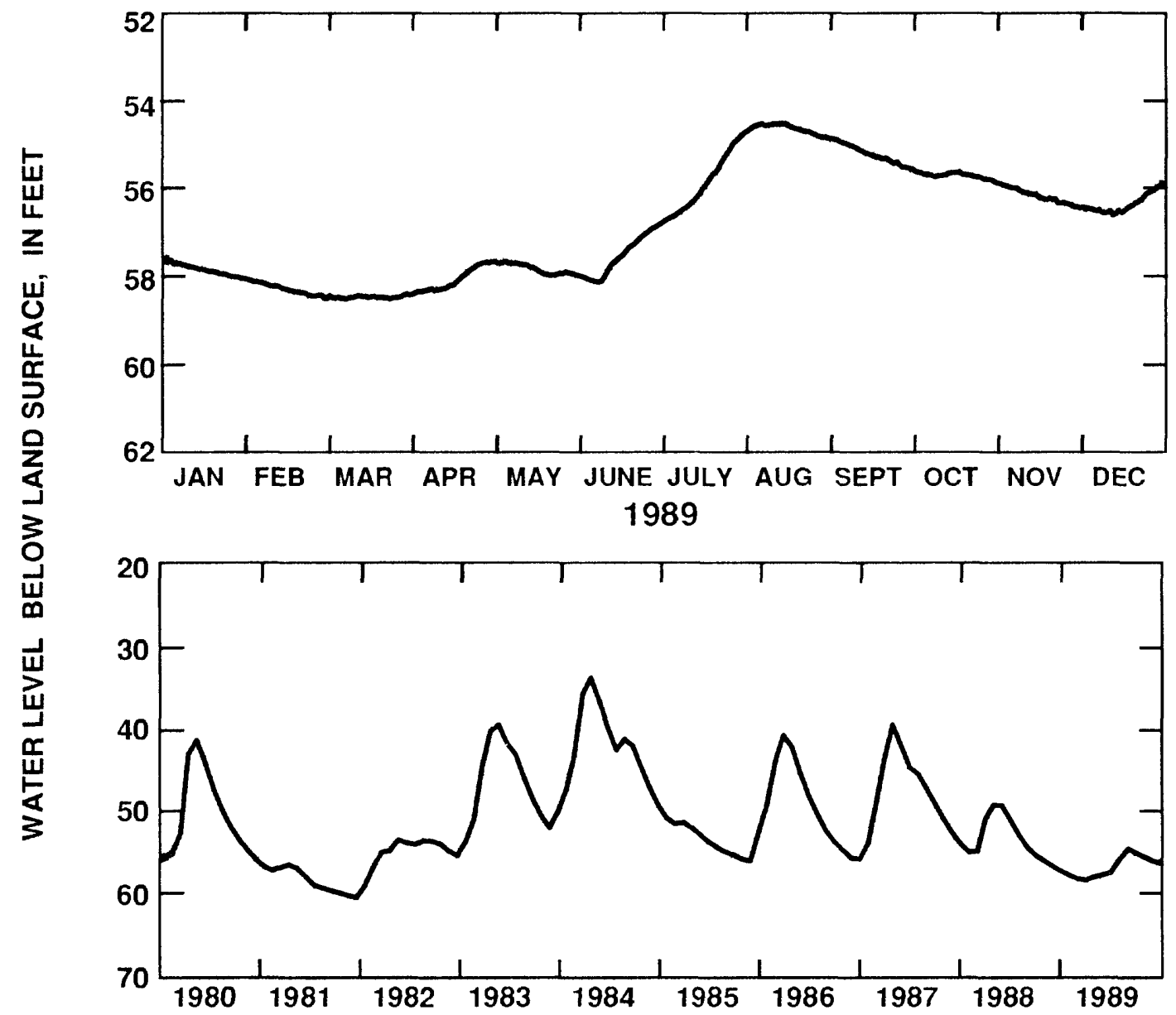

\begin{tabular}{|c|c|c|c|c|c|c|c|c|c|c|c|c|}
\hline 1989 & JAN & FEB & MAR & APR & MAY & JUN & JUL & $A \cup G$ & SEP & OCT & NOV & DEC \\
\hline $\begin{array}{l}\text { MEAN } \\
\text { MAX } \\
\text { MIN }\end{array}$ & $\begin{array}{l}57.88 \\
58.09 \\
57.64\end{array}$ & $\begin{array}{l}58.31 \\
58.50 \\
58.11\end{array}$ & $\begin{array}{l}58.49 \\
58.53 \\
58.42\end{array}$ & $\begin{array}{l}58.11 \\
58.43 \\
57.70\end{array}$ & $\begin{array}{l}57.86 \\
58.00 \\
57.69\end{array}$ & $\begin{array}{l}57.59 \\
58.16 \\
56.87\end{array}$ & $\begin{array}{l}55.95 \\
56.83 \\
54.78\end{array}$ & $\begin{array}{l}54.68 \\
54.90 \\
54.55\end{array}$ & $\begin{array}{l}55.26 \\
55.60 \\
54.91\end{array}$ & $\begin{array}{l}55.76 \\
55.91 \\
55.62\end{array}$ & $\begin{array}{l}56.22 \\
56.49 \\
55.94\end{array}$ & $\begin{array}{l}56.43 \\
56.68 \\
55.94\end{array}$ \\
\hline CAL YI & 1989 & & MEAN & 56.87 & & $\mathrm{HIGH}$ & 54.55 & & LOW & 58.53 & & \\
\hline
\end{tabular}

Figure 33.--Water level in observation well 10G313, Mitchell County. 
313748084002901 Local number, $13 \mathrm{~L} 003$.

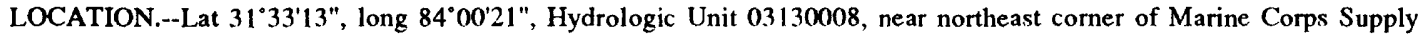
Center, in Acree.

Owner: City of Albany and Dougherty County.

AQUIFER.--Upper Floridan aquifer.

WELL CHARACTERISTICS.--Drilled unused supply well, diameter 6 in., depth $259 \mathrm{ft}$, cased to $206 \mathrm{ft}$, open hole.

DATUM.--Altitude of land-surface datum is $225 \mathrm{ft}$.

Measuring point: Top of recorder shelf, $4.10 \mathrm{ft}$ above land-surface datum.

REMARKS.--Well pumped and sounded June 21, 1978; water-quality sample collected at conclusion of pumping.

Borehole geophysical survey conducted March 17, 1977.

PERIOD OF RECORD.--January 1963 to current year.

EXTREMES FOR PERIOD OF RECORD.--Highest water leve1, $17.41 \mathrm{ft}$ below land-surface datum, April 2, 1965; lowest,

$44.89 \mathrm{ft}$ below land-surface datum, December $13,1981$.

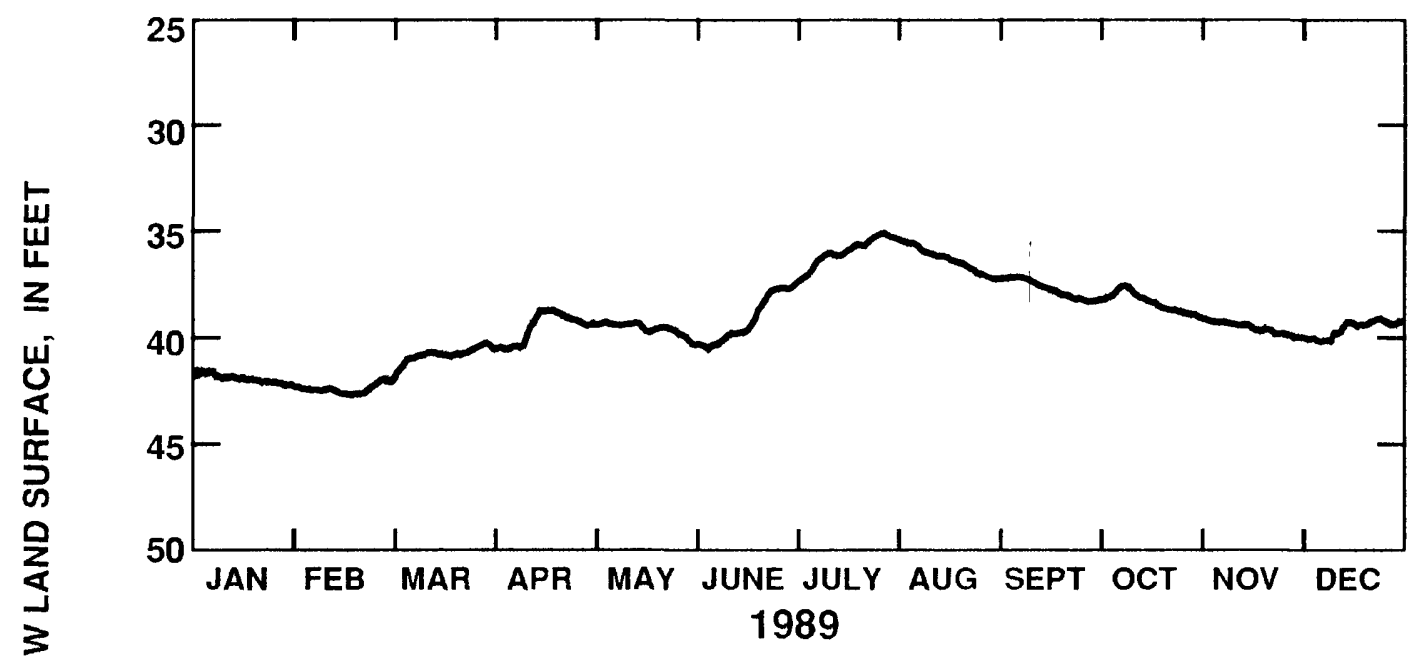

告

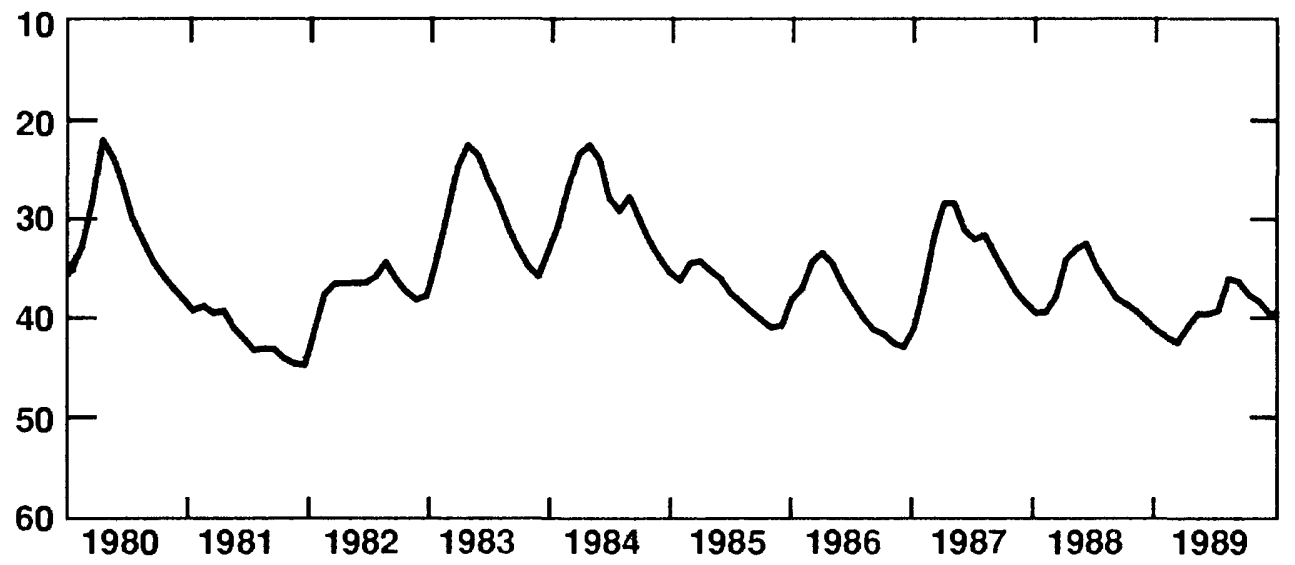

\begin{tabular}{|c|c|c|c|c|c|c|c|c|c|c|c|c|}
\hline 1989 & JAN & FEB & MAR & APR & MAY & JUN & JUL & AUG & SEP & OCT & NOV & DEC \\
\hline $\begin{array}{l}\text { MEAN } \\
\text { MAX } \\
\text { MIN }\end{array}$ & $\begin{array}{l}42.00 \\
42.37 \\
41.63\end{array}$ & $\begin{array}{l}42.49 \\
42.76 \\
41.99\end{array}$ & $\begin{array}{l}40.90 \\
42.12 \\
40.32\end{array}$ & $\begin{array}{l}39.59 \\
40.58 \\
38.75\end{array}$ & $\begin{array}{l}39.58 \\
40.33 \\
39.30\end{array}$ & $\begin{array}{l}39.26 \\
40.55 \\
37.64\end{array}$ & $\begin{array}{l}36.01 \\
37.48 \\
35.07\end{array}$ & $\begin{array}{l}36.31 \\
37.25 \\
35.35\end{array}$ & $\begin{array}{l}37.70 \\
38.33 \\
37.14\end{array}$ & $\begin{array}{l}38.34 \\
39.03 \\
37.56\end{array}$ & $\begin{array}{l}39.55 \\
40.04 \\
39.11\end{array}$ & $\begin{array}{l}39.63 \\
40.22 \\
39.12\end{array}$ \\
\hline CAL Y & 1989 & & MEAN & 39.26 & & $\mathrm{HIGH}$ & 35.07 & & LOW & 42.76 & & \\
\hline
\end{tabular}

Figure 34.--Water level in observation well 13L003, Dougherty County. 
312127084065801 Local number, $13 \mathrm{~J} 004$.

LOCATION.--Lat $31^{\circ} 21^{\prime} 29^{\prime \prime}$, long $84^{\circ} 06^{\prime} 57^{\prime \prime}$, Hydrologic Unit $00^{\circ} ; 30008,2.7$ mi north of intersection of U.S. Highway 19 and Ga. Highway $112,0.7$ mi west of Stagecoach Road.

Owner: Aurora Dairys, Wright 1.

AQUIFER ---Upper Floridan aquifer.

WELL CHARACTERISTICS.--Drilled observation well, diameter 12 in., depth $208 \mathrm{ft}$, cased to $77 \mathrm{ft}$, open hole.

DATUM.--Altitude of land-surface datum is $200 \mathrm{ft}$.

Measuring point: Top of recorder shelf, $3.60 \mathrm{ft}$ above land-surface datum.

REMARKS.--None.

PERIOD OF RECORD.--June 1978 to current year.

EXTREMES FOR PERIOD OF RECORD.--Highest water level, $36.90 \mathrm{ft}$ below land-surface datum, April 13, 1980; lowest, $54.00 \mathrm{ft}$ below land-surface datum, September 25,1981 .

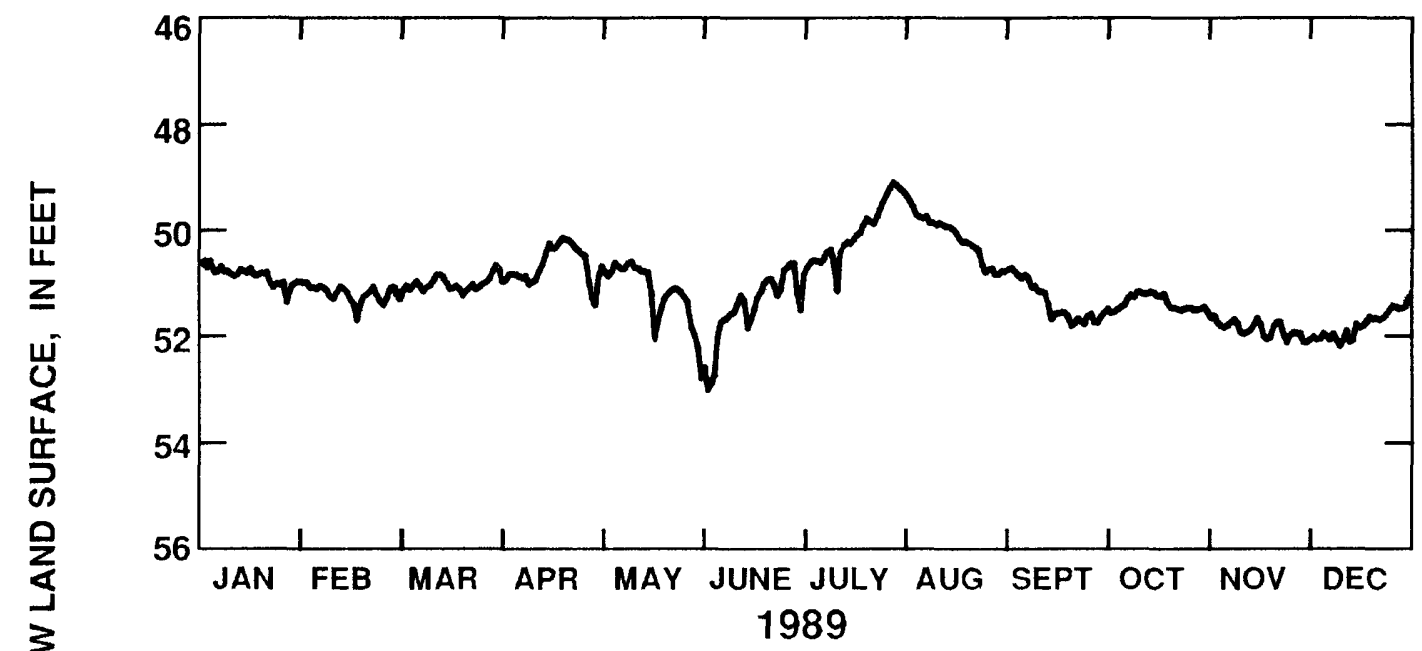

\begin{tabular}{|c|c|c|c|c|c|c|c|c|c|c|c|c|}
\hline 1989 & JAN & FEB & MAR & APR & MAY & JUN & JUL & AUG & SEP & OCT & NOV & DEC \\
\hline $\begin{array}{l}\text { MEAN } \\
\text { MAX } \\
\text { MIN }\end{array}$ & $\begin{array}{l}50.89 \\
51.39 \\
50.60\end{array}$ & $\begin{array}{l}51.23 \\
51.72\end{array}$ & $\begin{array}{l}51.05 \\
51.32 \\
50.69\end{array}$ & $\begin{array}{l}50.70 \\
51.45 \\
50.17\end{array}$ & $\begin{array}{l}51.19 \\
52.83\end{array}$ & $\begin{array}{l}51.51 \\
53.04 \\
50.66\end{array}$ & $\begin{array}{l}50.09 \\
51.18\end{array}$ & $\begin{array}{l}50.18 \\
50.88\end{array}$ & $\begin{array}{l}51.41 \\
51.85 \\
50.76\end{array}$ & $\begin{array}{l}51.42 \\
51.60\end{array}$ & $\begin{array}{l}51.92 \\
52.17 \\
51.67\end{array}$ & $\begin{array}{l}51.85 \\
52.24 \\
51.33\end{array}$ \\
\hline CAL YF & 1989 & & MEAN & 51.12 & & $\mathrm{HIGH}$ & 49.13 & & LOW & 53.04 & & \\
\hline
\end{tabular}

Figure 35.--Water level in observation well 13J004, Mitchell County. 
313146083491601 Local number, 15L020.

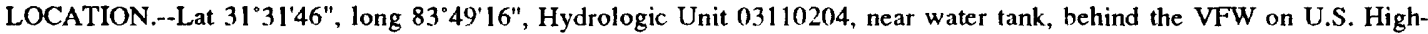
way 82 east, Sylvester.

Owner: City of Sylvester.

AQUIFER.--Upper Floridan aquifer.

WELL CHARACTERISTICS.--Drilled unused municipal well, diameter 18 in., depth $450 \mathrm{ft}$, cased to $212 \mathrm{ft}$, open hole.

DATUM.--Altitude of land-surface datum is $420 \mathrm{ft}$.

Measuring point: Top of recorder shelf, $2.90 \mathrm{ft}$ above land-surface datum.

REMARKS.--Well pumped and sounded July 19, 1978. Borehole geophysical survey conducted June 5, 1975.

PERIOD OF RECORD.--May 1972 to current year.

EXTREMES FOR PERIOD OF RECORD.--Highest water level, $191.5 \mathrm{ft}$ below land-surface datum, May 17, 1973; lowest, $204.67 \mathrm{ft}$ below land-surface datum. August 10, 1986.

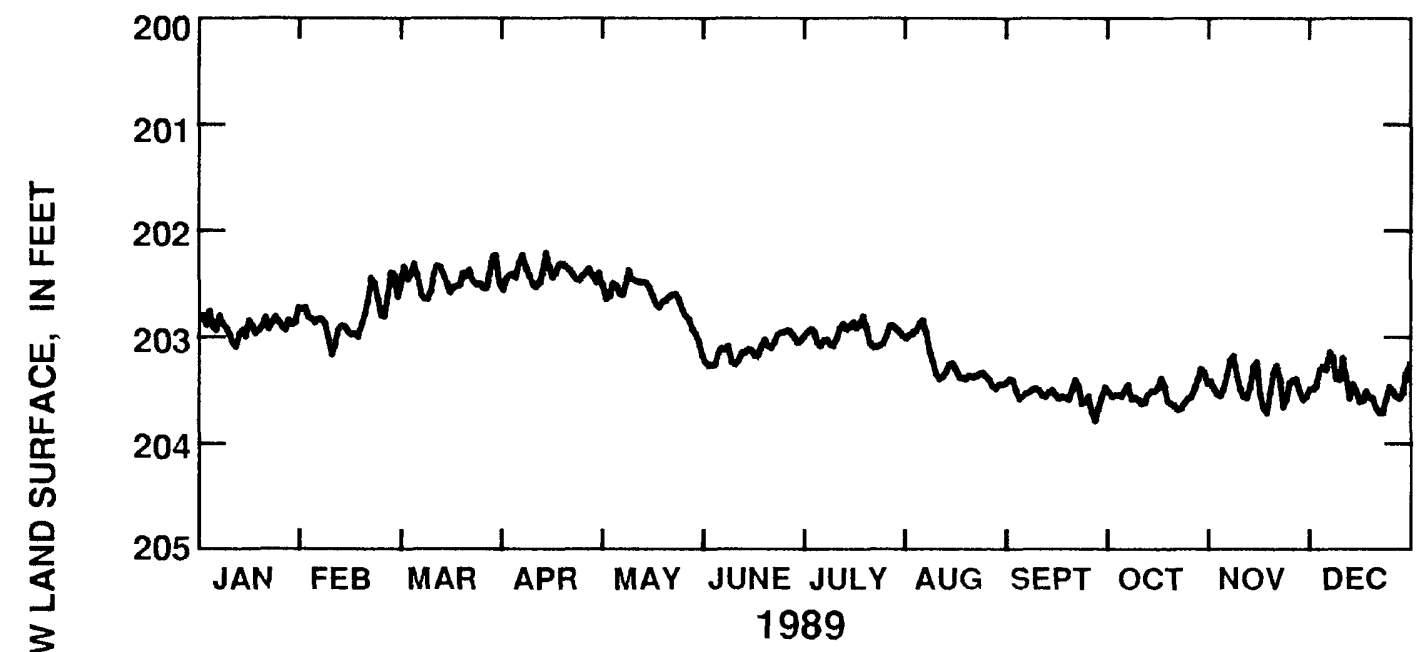

\begin{tabular}{|c|c|c|c|c|c|c|c|c|c|c|c|c|}
\hline 1989 & JAN & FEB & MAR & APR & MAY & JUN & JUL & AUG & SEP & OCT & NOV & DEC \\
\hline $\begin{array}{l}\text { MEAN } \\
\text { MAX } \\
\text { MIN }\end{array}$ & $\begin{array}{l}202.89 \\
203.09 \\
202.72\end{array}$ & $\begin{array}{l}202.81 \\
203.17 \\
202.39\end{array}$ & $\begin{array}{l}202.46 \\
202.64 \\
202.23\end{array}$ & $\begin{array}{l}202.41 \\
202.56 \\
202.21\end{array}$ & $\begin{array}{l}202.63 \\
203.05 \\
202.38\end{array}$ & $\begin{array}{l}203.13 \\
203.28 \\
202.95\end{array}$ & $\begin{array}{l}202.99 \\
203.11 \\
202.82\end{array}$ & $\begin{array}{l}203.27 \\
203.51 \\
202.86\end{array}$ & $\begin{array}{l}203.57 \\
203.82 \\
203.42\end{array}$ & $\begin{array}{l}203.57 \\
203.72 \\
203.33\end{array}$ & $\begin{array}{l}203.49 \\
203.76 \\
203.21\end{array}$ & $\begin{array}{l}203.51 \\
203.76 \\
203.18\end{array}$ \\
\hline CAL Y & /R 1989 & & MEAN & 203.06 & & HIGH & 202.2 & & LOW & 203.8 & & \\
\hline
\end{tabular}

Figure 36.--Water level in observation well 15L020, Worth County. 
312712082593301 Local number, $18 \mathrm{~K} 049$.

LOCATION.--Lat $31^{\circ} 27^{\prime} 12^{\prime \prime}$, long 82.59'33", Hydrologic Unit 03110203 , near the intersection of Goff Street and Ferry Lake Road, at city of Tifton Maintence and Water Works, on east side of Tifton.

Owner: U.S. Geological Survey test well 1.

AQUIFER.--Upper Floridan aquifer.

WELL CHARACTERISTICS.--Drilled observation well, diameter 6 in., depth $620 \mathrm{ft}$, cased to $270 \mathrm{ft}$, open hole.

DATUM.--Altitude of land-surface datum is $330 \mathrm{ft}$.

Measuring point: Top of recorder shelf, $3.0 \mathrm{ft}$ above land-surface datum.

REMARKS.--Borehole geophysical survey conducted March 18, 1978.

PERIOD OF RECORD.--March 28, 1978 to current year.

EXTREMES FOR PERIOD OF RECORD.--Highest water leve1, $102.70 \mathrm{ft}$ below land-surface datum, May 14, 1978; lowest,

$121.61 \mathrm{ft}$ below land-surface datum, August 10-11, 1988.
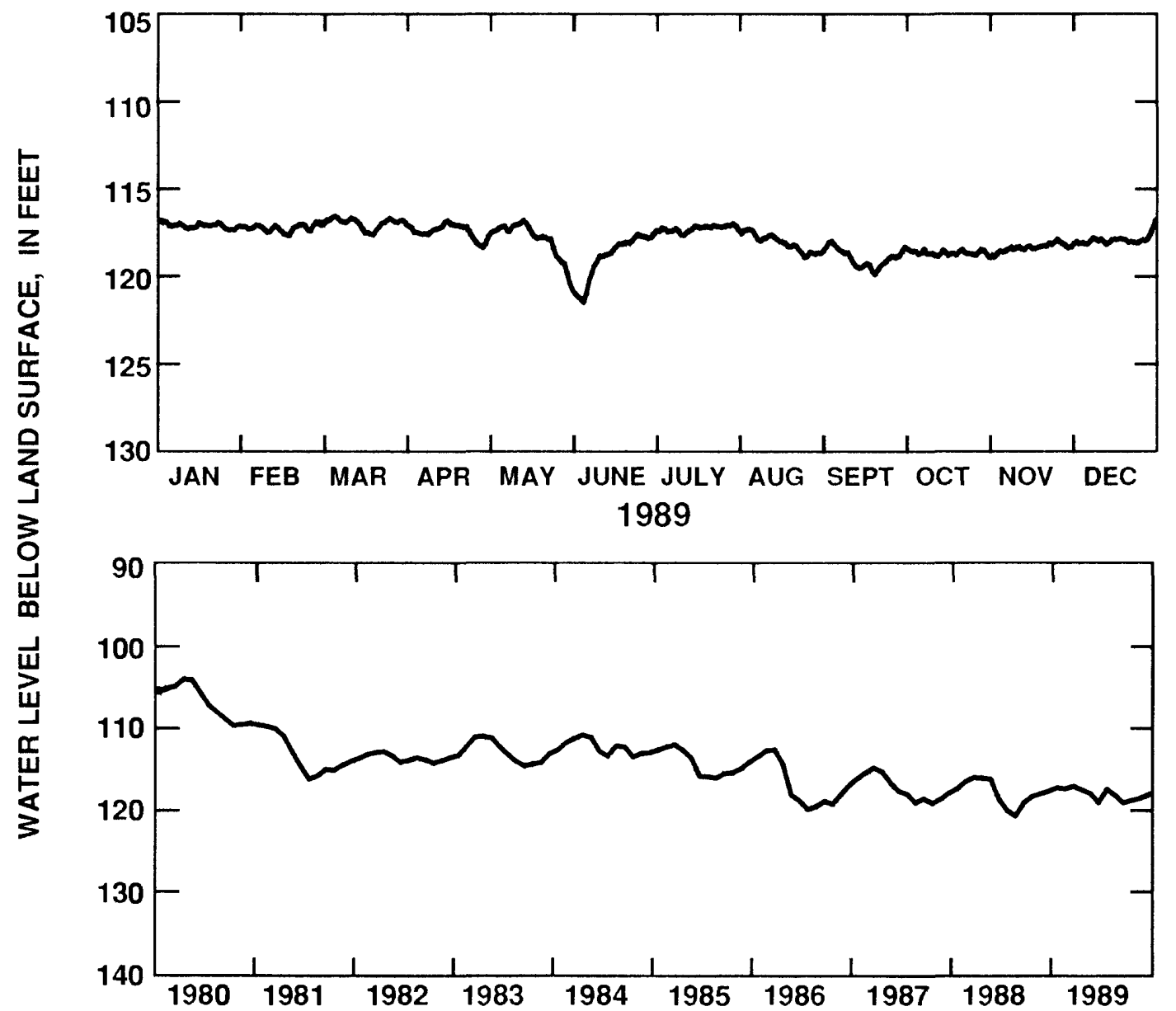

1989 JAN FEB MAR APR MAY JUN JUL AUG SEP OCT NOV DEC

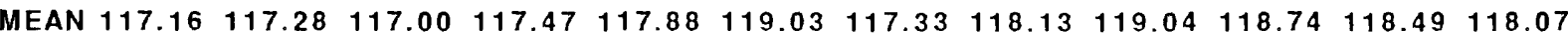

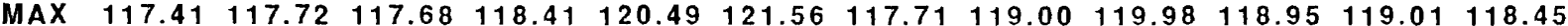

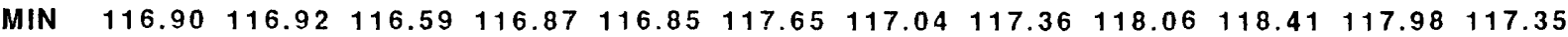

$\begin{array}{lllllll}\text { CAL YR } 1989 & \text { MEAN } & 117.97 & \text { HIGH } & 116.59 & \text { LOW } & 121.56\end{array}$

Figure 37.--Water level in observation well 18K049, Tift County. 
310813083260301 Local number, $18 \mathrm{H} 016$.

LOCATION.--Lat $31^{\circ} 08^{\prime} 13^{\prime \prime}$, long $83^{\circ} 26^{\circ} 03^{\prime \prime}$, Hydrologic Unit 03110203, on west side of the intersection of Second Street and North Elm Street, 0.3 mi north of intersection of Ga. Highway 76 and 37, in Adel.

Owner: U.S. Geological Survey, Adel test well.

AQUIFER.--Upper Floridan aquifer.

WELL CHARACTERISTICS.--Drilled observation well, diameter 8 in., depth $865 \mathrm{ft}$, cased to $207 \mathrm{ft}$, open hole.

DATUM.--Altitude of land-surface datum is $241 \mathrm{ft}$.

Measuring point: Top of recorder shelf, $2.66 \mathrm{ft}$ above land-surface datum.

REMARKS.--Well pumped July 19, 1978: water-quality sample collected at conclusion of pumping. Borehole geo-

physical survey conducted October 24, 1974.

PERIOD OF RECORD.--December 1964 to current year.

EXTREMES FOR PERIOD OF RECORD.--Highest water level, $163.34 \mathrm{ft}$ below land-surface datum, July 5, 1966; lowest,

$175.75 \mathrm{ft}$ below land-surface datum, July $22,1988$.
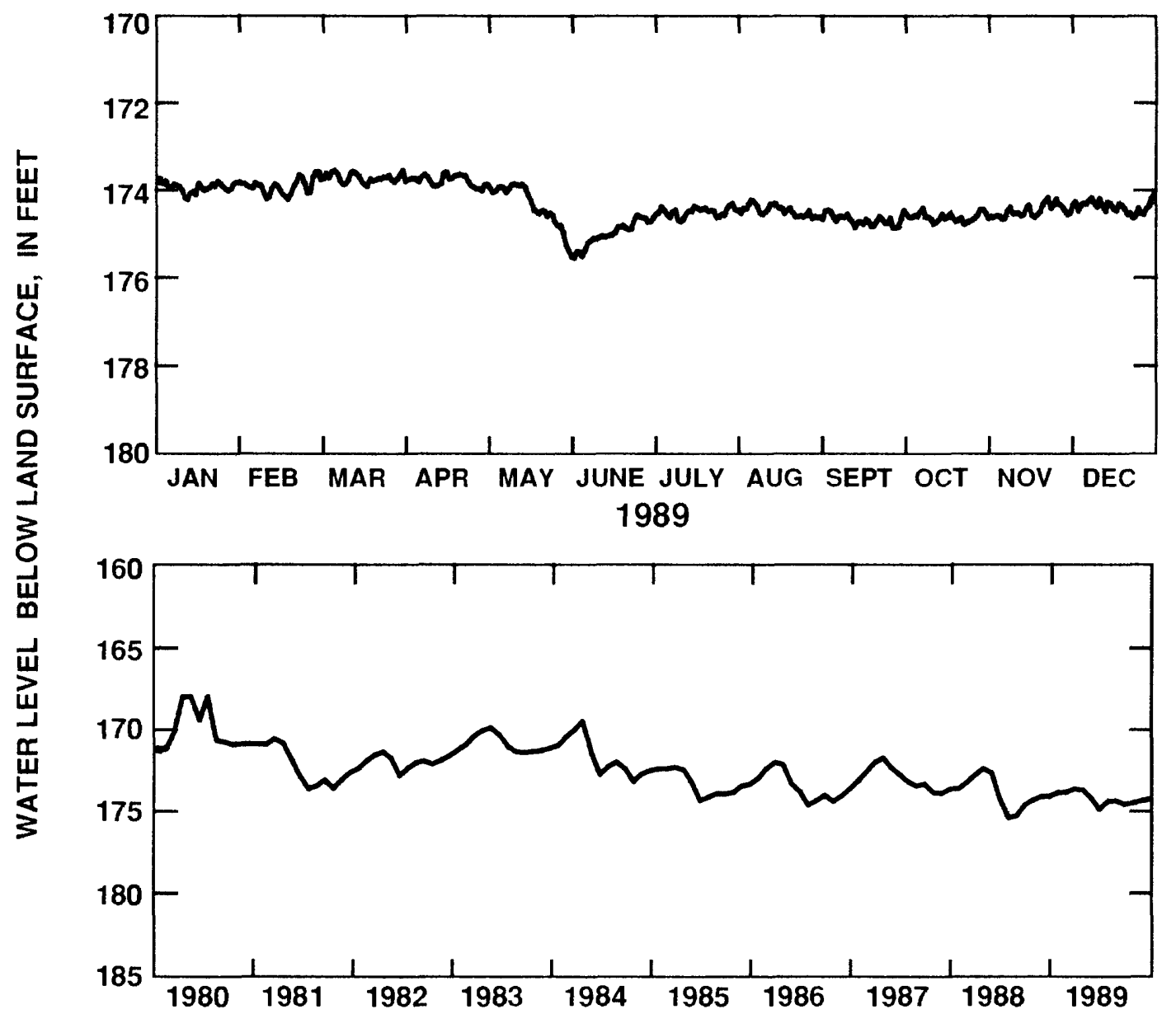

\begin{tabular}{|c|c|c|c|c|c|c|c|c|c|c|c|c|}
\hline 1989 & JAN & FEB & MAR & APR & MAY & JUN & JUL & AUG & SEP & OCT & NOV & DEC \\
\hline $\begin{array}{l}\text { MEAN } \\
\text { MAX } \\
\text { MIN }\end{array}$ & $\begin{array}{l}173.93 \\
174.21 \\
173.78\end{array}$ & $\begin{array}{l}173.92 \\
174.21 \\
173.57\end{array}$ & $\begin{array}{l}173.71 \\
173.91 \\
173.53\end{array}$ & $\begin{array}{l}173.77 \\
174.01 \\
173.58\end{array}$ & $\begin{array}{l}174.30 \\
175.38 \\
173.85\end{array}$ & $\begin{array}{l}175.00 \\
175.55 \\
174.56\end{array}$ & $\begin{array}{l}174.49 \\
174.71 \\
174.29\end{array}$ & $\begin{array}{l}174.46 \\
174.64 \\
174.21\end{array}$ & $\begin{array}{l}174.68 \\
174.85 \\
174.45\end{array}$ & $\begin{array}{l}174.60 \\
174.77 \\
174.40\end{array}$ & $\begin{array}{l}174.47 \\
174.64 \\
174.17\end{array}$ & $\begin{array}{l}174.38 \\
174.63 \\
174.16\end{array}$ \\
\hline AL & & & MEAN & 174.31 & & $\mathrm{HIGH}$ & 173.5 & & LOW & 175.5 & & \\
\hline
\end{tabular}

Figure 38.--Water level in observation well 18H016, Cook County. 
304949083165301 Local number, 19E009.

LOCATION.--Lat $30^{\circ} 49^{\prime} 51^{\prime \prime}$, long $83^{\circ} 16^{\prime} 58^{\prime \prime}$, Hydrologic Unit 03110202 , N. Oak Street, one block north of intersection with U.S. Highway 84, Valdosta.

Owner: City of Valdosta.

AQUIFER.--Upper Floridan aquifer.

WELL CHARACTERISTICS.--Drilled unused municipal supply well, diameter $20 \mathrm{in}$., depth $342 \mathrm{ft}$, cased to $200 \mathrm{ft}$, open

hole.

DATUM.--Altitude of land-surface datum is $217 \mathrm{ft}$.

Measuring point: Top of casing, $1.7 \mathrm{ft}$ above land-surface datum

REMARKS.--Well pumped July 18, 1978: water-quality sample collected at conclusion of pumping. Borehole geophysical survey conducted April 11, 1963.

PERIOD OF RECORD.--February 1957 to current year.

EXTREMES FOR PERIOD OF RECORD.--Highest water level, $112.69 \mathrm{ft}$ below land-surface datum, March 9, 1964: lowest, $146.60 \mathrm{ft}$ below land-surface datum, July 18,1981 .
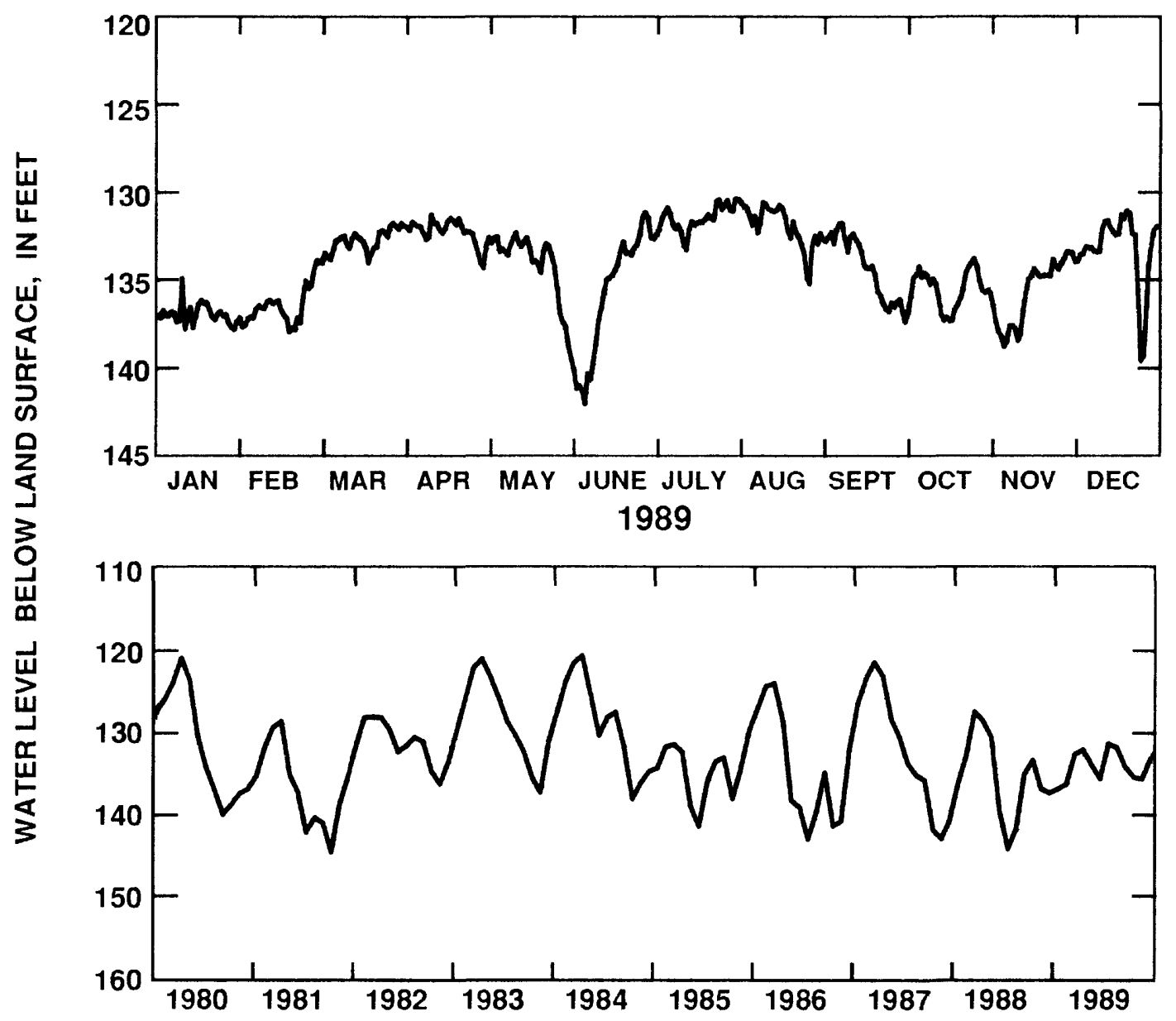

\begin{tabular}{|c|c|c|c|c|c|c|c|c|c|c|c|c|}
\hline 1989 & JAN & FEB & MAR & APR & MAY & JUN & JUL & AUG & SEP & OCT & NOV & DEC \\
\hline $\begin{array}{l}\text { MEAN } \\
\text { MAX } \\
\text { MIN }\end{array}$ & $\begin{array}{l}136.97 \\
137.78 \\
134.87\end{array}$ & $\begin{array}{l}136.39 \\
137.93 \\
133.87\end{array}$ & $\begin{array}{l}132.73 \\
134.00 \\
131.72\end{array}$ & $\begin{array}{l}132.22 \\
134.28 \\
131.23\end{array}$ & $\begin{array}{l}134.06 \\
139.42 \\
132.31\end{array}$ & $\begin{array}{l}135.74 \\
142.07 \\
131.11\end{array}$ & $\begin{array}{l}131.46 \\
133.27 \\
130.33\end{array}$ & $\begin{array}{l}131.94 \\
135.22 \\
130.52\end{array}$ & $\begin{array}{l}134.31 \\
137.42 \\
131.78\end{array}$ & $\begin{array}{l}135.57 \\
137.36 \\
133.83\end{array}$ & $\begin{array}{l}135.81 \\
138.85 \\
133.45\end{array}$ & $\begin{array}{l}133.33 \\
139.71 \\
131.09\end{array}$ \\
\hline$A L$ & 98 & & MEAN & 134.1 & & HIGH & 130.3 & & LOW & 142.0 & & \\
\hline
\end{tabular}

Figure 39.--Water level in observation well 19E009, Lowndes County. 
305241083154401 Local number, $19 \mathrm{F0} 039$.

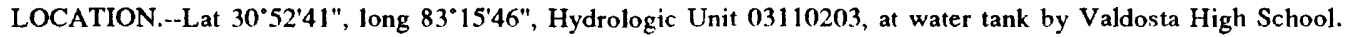

Owner: City of Valdosta well 8.

AQUIFER.--Upper Floridan aquifer.

WELL CHARACTERISTICS.--Drilled unused municipal supply well, diameter 16 in., depth $450 \mathrm{ft}$, cased to $350 \mathrm{ft}$, open hole.

DATUM.--Altitude of land-surface datum is $222 \mathrm{ft}$.

Measuring point: Pump base, $1.40 \mathrm{ft}$ above land-surface datum.

REMARKS.--None.

PERIOD OF RECORD.--February 1979 to current year.

EXTREMES FOR PERIOD OF RECORD.--Highest water level, $114.28 \mathrm{ft}$ below land-surface datum, April 9, 1984; lowest,

$145.67 \mathrm{ft}$ below land-surface datum, October 24, 1981.
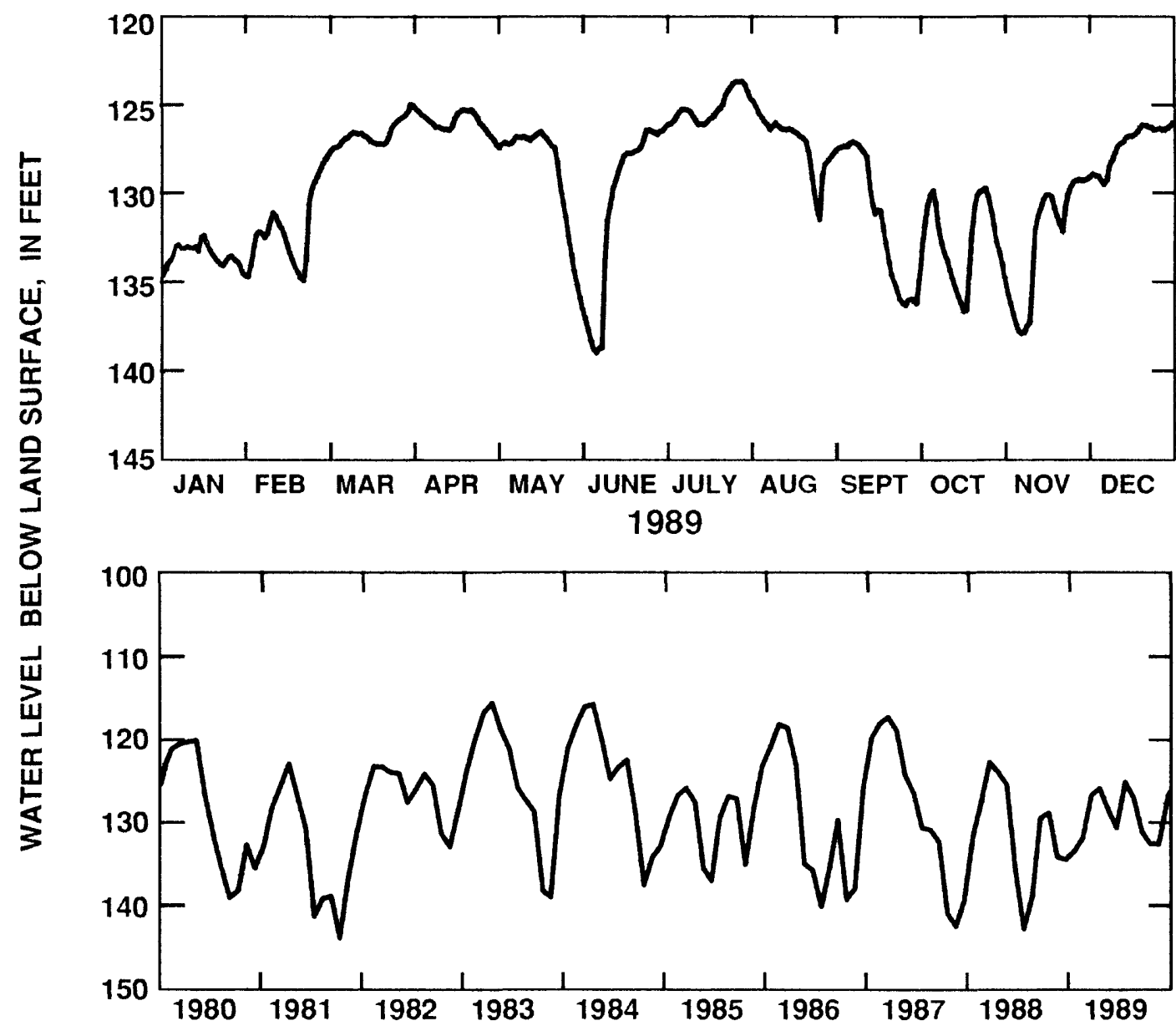

\begin{tabular}{|c|c|c|c|c|c|c|c|c|c|c|c|c|}
\hline 1989 & JAN & FEB & MAR & APR & MAY & JUN & JUL & AUG & SEP & OCT & NOV & DEC \\
\hline $\begin{array}{l}\text { MEAN } \\
\text { MAX } \\
\text { MIN }\end{array}$ & $\begin{array}{l}133.57 \\
134.75 \\
132.42\end{array}$ & $\begin{array}{l}131.99 \\
134.95 \\
128.10\end{array}$ & $\begin{array}{l}126.71 \\
127.85 \\
124.95\end{array}$ & $\begin{array}{l}125.90 \\
126.97 \\
125.04\end{array}$ & $\begin{array}{l}128.56 \\
135.89 \\
126.51\end{array}$ & $\begin{array}{l}130.76 \\
139.01 \\
126.39\end{array}$ & $\begin{array}{l}125.15 \\
126.22 \\
123.63\end{array}$ & $\begin{array}{l}127.03 \\
131.50 \\
124.64\end{array}$ & $\begin{array}{l}131.27 \\
136.34 \\
127.06\end{array}$ & $\begin{array}{l}132.68 \\
136.66 \\
129.75\end{array}$ & $\begin{array}{l}132.74 \\
137.92 \\
129.25\end{array}$ & $\begin{array}{l}127.36 \\
129.52 \\
126.13\end{array}$ \\
\hline$A L$ & 1989 & & MEAN & 129.4 & & $\mathrm{HIGH}$ & 123.6 & & LOW & 139.0 & & \\
\hline
\end{tabular}

Figure 40.--Water level in observation well 19F039, Lowndes County. 


\section{East-central area}

The water level in the Upper Floridan aquifer in east-central Georgia is monitored in three wells, all of which are included in this report (figs. 41-43). During 1987, an estimated $16 \mathrm{Mgal} / \mathrm{d}$ was withdrawn from aquifers in east-central Georgia (Trent and others,1990), much of which was from the Upper Floridan aquifer. Well 21T001 (fig. 41) in Laurens County is near the recharge area for the Upper Floridan aquifer and the water level in this well responds primarily to seasonal fluctuations in precipitation. The mean water level in well 21T001 was $2.3 \mathrm{ft}$ higher in 1989 than in 1988. This water-level rise is a result of increased recharge due to above-normal precipitation during the summer of 1989 (see precipitation graph for Macon, fig. 12).

In Montgomery and Toombs Counties, the water level in the Upper Floridan aquifer is affected primarily by changes in local and regional pumping. This response is shown on the hydrographs for well 25Q001 in Montgomery County (fig. 42) and well 26R001 in Toombs County (fig. 43). The mean water levels in wells 25Q001 and 26R001 were $0.4 \mathrm{ft}$ higher in 1989 than in 1988. Although wells in this area showed a slight water-level rise during 1989 , the long-term trend is a general decline.

\section{Coastal area}

The water level in the Upper Floridan aquifer in the coastal area is monitored in 22 wells, records from 15 are included in this report (figs. 44-59). Water levels in wells tapping the aquifer in this area are influenced primarily by local and regional pumping. Because the Upper Floridan aquifer is deeply buried and far from the outcrop area, the ground-water level is not influenced by concurrent precipitation, but rather by increased withdrawal during dry periods and decreased withdrawal during wet periods (Clarke and others, 1990).

In this area and adjacent parts of Florida and South Carolina, the water-level map of the Upper Floridan aquifer is characterized by cones of depression that are caused by large ground-water withdrawal primarily in the Savannah, Jesup-Riceboro, Brunswick, and St Marys, Ga.-Fernandina Beach, Fla., areas. Pumpage in the coastal area of Georgia in 1987 was about $321 \mathrm{Mgal} / \mathrm{d}$, about 69 percent of which was used for industrial purposes (Trent and others, 1990). In the coastal area of Georgia, nearly all the ground-water withdrawal is from the Floridan aquifer system. The coastal area is divided into four hydrologic subareas on the basis of major pumping centers (1) the Savannah area, (2) the Jesup-Riceboro area, (3) the Brunswick area, and (4) the Kings Bay-Okefenokee Swamp area (fig. 27).

\section{Savannah Area}

The water levels in the Upper Floridan aquifer in the Savannah area are monitored in eight wells, records from five are included in this report (figs. 45-49). In this area, the water level in the Upper Floridan aquifer primarily is affected by pumping for municipal and industrial uses. As a result of pumping, a cone of depression has developed in the water-level surface at Savannah. In 1987, withdrawal from the Floridan aquifer system exceeded $78 \mathrm{Mgal} / \mathrm{d}$ in the Savannah area (Trent and others, 1990).

Hydrographs for observation wells near the center of pumping, and in outlying areas, illustrate the effects of pumping on the ground-water levels. The mean water levels in wells 36Q008, 36Q020, 38Q002 and 39 Q003 in the area of the cone of depression at Savannah were from 0.7 to $2.0 \mathrm{ft}$ lower in 1989 than in 1988, which continued a general downward trend that began in 1983 (figs. 45-48). Water-level declines in these wells are attributed to regional pumping and below-normal precipitation during much of the year. (See precipitation graph for Savannah, fig. 11.) Observation well 32R002 (fig. 49), located west of the pumping center at Savannah in Bulloch County, responds to changes in pumping at Savannah, but to a lesser degree than those wells in the area of the cone of depression. The mean water level in well 32R002 was $0.3 \mathrm{ft}$ lower in 1989 than in 1988, continuing the general downward trend since monitoring of the well began in 1983. 
322652083033001 Local number, $21 \mathrm{~T} 001$.

LOCATION.--Lat 32 $27^{\prime} 06^{\prime \prime}$, long $8^{\circ} 03^{\prime} 28^{\prime \prime}$, Hydrologic Unit 03070102, $1.0 \mathrm{mi}$ east of Ga. Highway 338 on dirt road, $1.5 \mathrm{mi}$ northwest of Dexter.

Owner: Danny Hogan.

AQUIFER.--Upper Floridan aquifer.

WELL CHARACTERISTICS.--Drilled unused supply well, diameter 4 in., depth $123 \mathrm{ft}$, cased to $89 \mathrm{ft}$, open hole.

DATUM.--Altitude of land-surface datum is $259 \mathrm{ft}$.

Measuring point: Top of recorder shelf, $2.57 \mathrm{ft}$ above land-surface datum.

REMARKS.--Borehole geophysical survey conducted November 1973.

PERIOD OF RECORD.--March 1964 to current year.

EXTREMES FOR PERIOD OF RECORD.--Highest water level, $23.62 \mathrm{ft}$ below land-surface datum, January 26, 1987 ; lowest,

$39.58 \mathrm{ft}$ below land-surface datum, November 12, 1968.

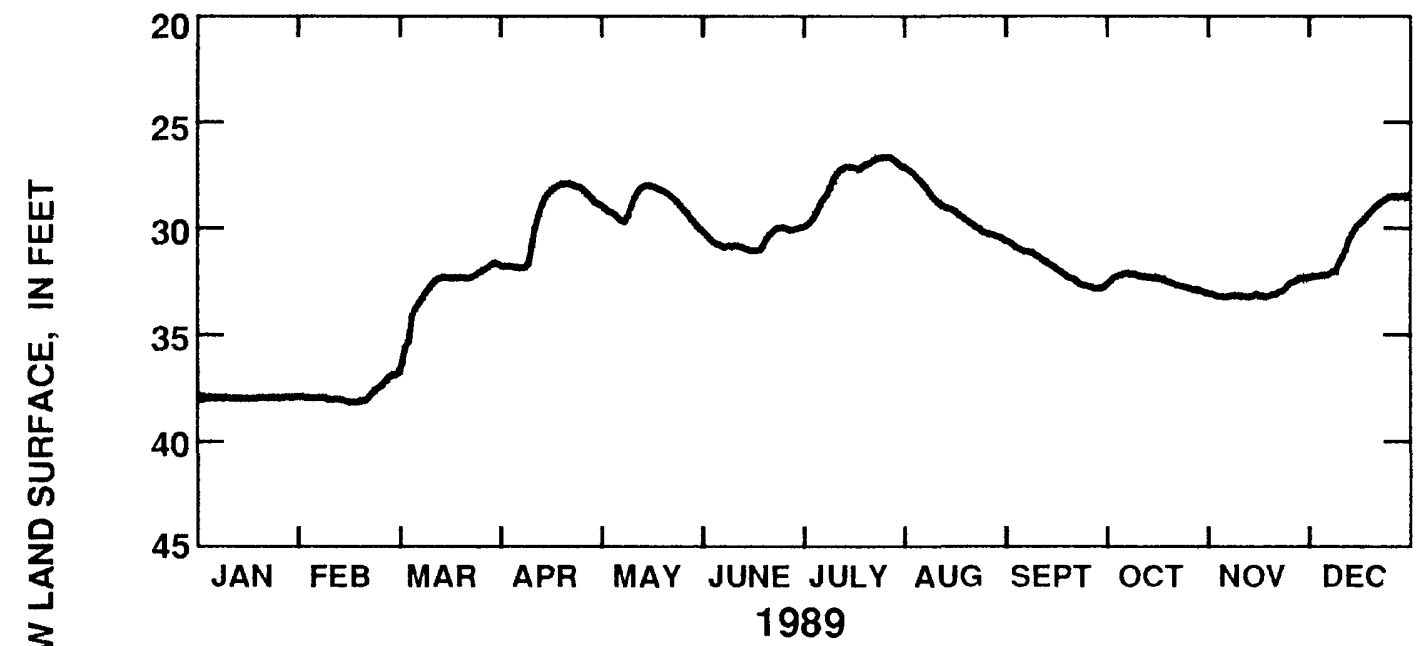

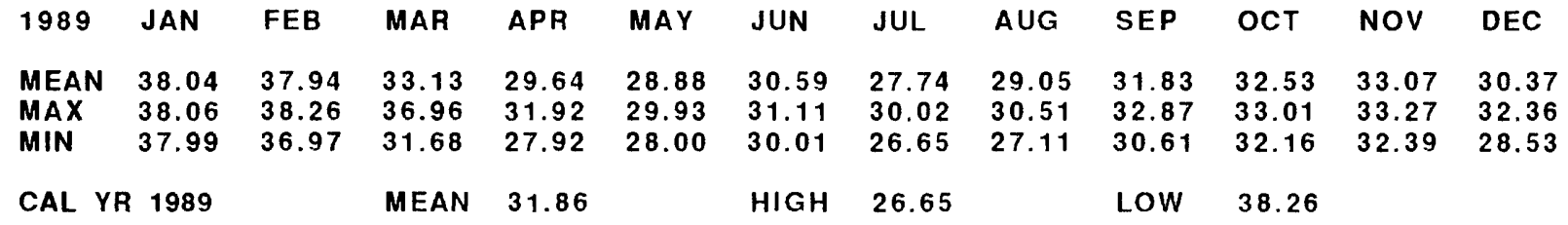

Figure 41.--Water level in observation well 21T001, Laurens County. 
320226082301101 Local number, 250001.

LOCATION.--Lat $32^{\circ} 02^{\prime} 25^{\prime \prime}$, long $82^{\circ} 30^{\prime} 05^{\prime \prime}$, Hydrologic Unit 03070106, well is located behind the Uvalda School, in Uvalda.

Owner: Montgomery County Board of Education.

AQUIFER.--Upper Floridan aquifer.

WELL CHARACTERISTICS.--Drilled unused supply well, diameter $6 \mathrm{in}$., depth $536 \mathrm{ft}$, cased to $421 \mathrm{ft}$, open hole.

DATUM.--Altitude of land-surface datum is $190 \mathrm{ft}$.

Measuring point: Top of 6 in. casing at land-surface.

REMARKS.--Borehole ge ophysical survey conducted April 22, 1966.

PERIOD OF RECORD.--June 1966 to current year.

EXTREMES FOR PERIOD OF RECORD.--Highest water level, $64.13 \mathrm{ft}$ below land-surface datum, June 10, 1966: lowest, $82.27 \mathrm{ft}$ below land-surface datum, July 17,1986

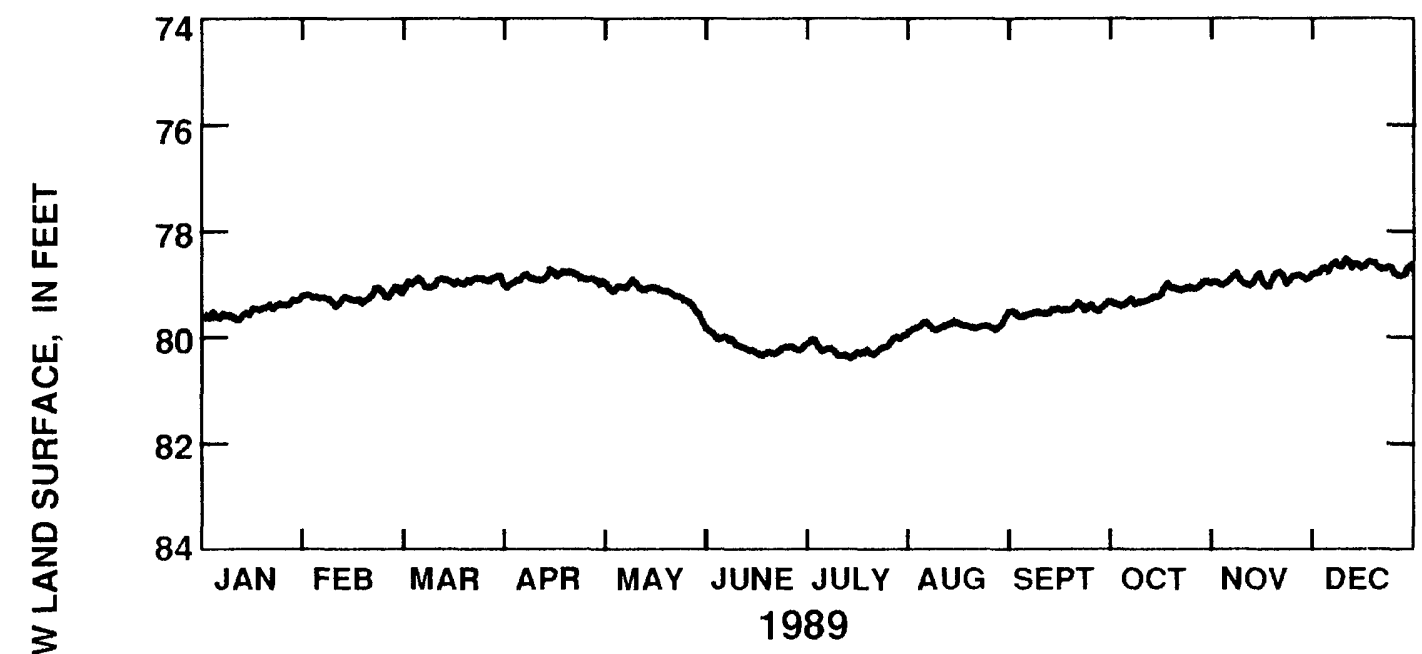

\begin{tabular}{|c|c|c|c|c|c|c|c|c|c|c|c|c|}
\hline 1989 & JAN & FEB & MAR & APR & MAY & JUN & JUL & $\mathbf{A U G}$ & SEP & OCT & NOV & DEC \\
\hline $\begin{array}{l}\text { MEAN } \\
\text { MAX } \\
\text { MIN }\end{array}$ & $\begin{array}{l}79.51 \\
79.70 \\
79.24\end{array}$ & $\begin{array}{l}79.27 \\
79.46 \\
79.08\end{array}$ & $\begin{array}{l}78.99 \\
79.20 \\
78.88\end{array}$ & $\begin{array}{l}78.92 \\
79.10 \\
78.76\end{array}$ & $\begin{array}{l}79.20 \\
79.75 \\
78.94\end{array}$ & $\begin{array}{l}80.21 \\
80.39 \\
79.87\end{array}$ & $\begin{array}{l}80.27 \\
80.45 \\
80.03\end{array}$ & $\begin{array}{l}79.85 \\
80.00 \\
79.67\end{array}$ & $\begin{array}{l}79.55 \\
79.67 \\
79.40\end{array}$ & $\begin{array}{l}79.25 \\
79.47 \\
79.00\end{array}$ & $\begin{array}{l}78.97 \\
79.10 \\
78.83\end{array}$ & $\begin{array}{l}78.76 \\
78.95 \\
78.58\end{array}$ \\
\hline CAL YR & 1989 & & MEAN & 79.40 & & $\mathrm{HIG}^{\prime}$ & 78.58 & & LOW & 80.45 & & \\
\hline
\end{tabular}

Figure 42.--Water level in observation well 25Q001, Montgomery County. 
321302082243601 Local number, 26R001.

LOCATION.--Lat $32^{\circ} 13^{\prime} 02^{\prime \prime}$, long $82^{\circ} 24^{\prime} 36^{\prime \prime}$, Hydrologic Unit 03070107, $15 \mathrm{ft}$ south of the Vidalia Water and Street Department and Fire Station.

Owner: City of Vidalia well 2

AQUIFER.--Upper Floridan aquifer.

WELL CHARACTERISTICS.--Drilled municipal supply well, diameter $12 \mathrm{in}$., depth $1,000 \mathrm{ft}$, cased to $720 \mathrm{ft}$, open hole.

DATUM.--Altitude of land-surface datum is $285 \mathrm{ft}$.

Measuring point: Top of 12 in. casing.

REMARKS.--None.

PERIOD OF RECORD.--April 1974 to current

EXTREMES FOR PERIOD OF RECORD.--Highest water level, $151.64 \mathrm{ft}$ helow land-surface datum, April 15, 1974; lowest,

$171.94 \mathrm{ft}$ below land-surface datum, July 10, 1986.

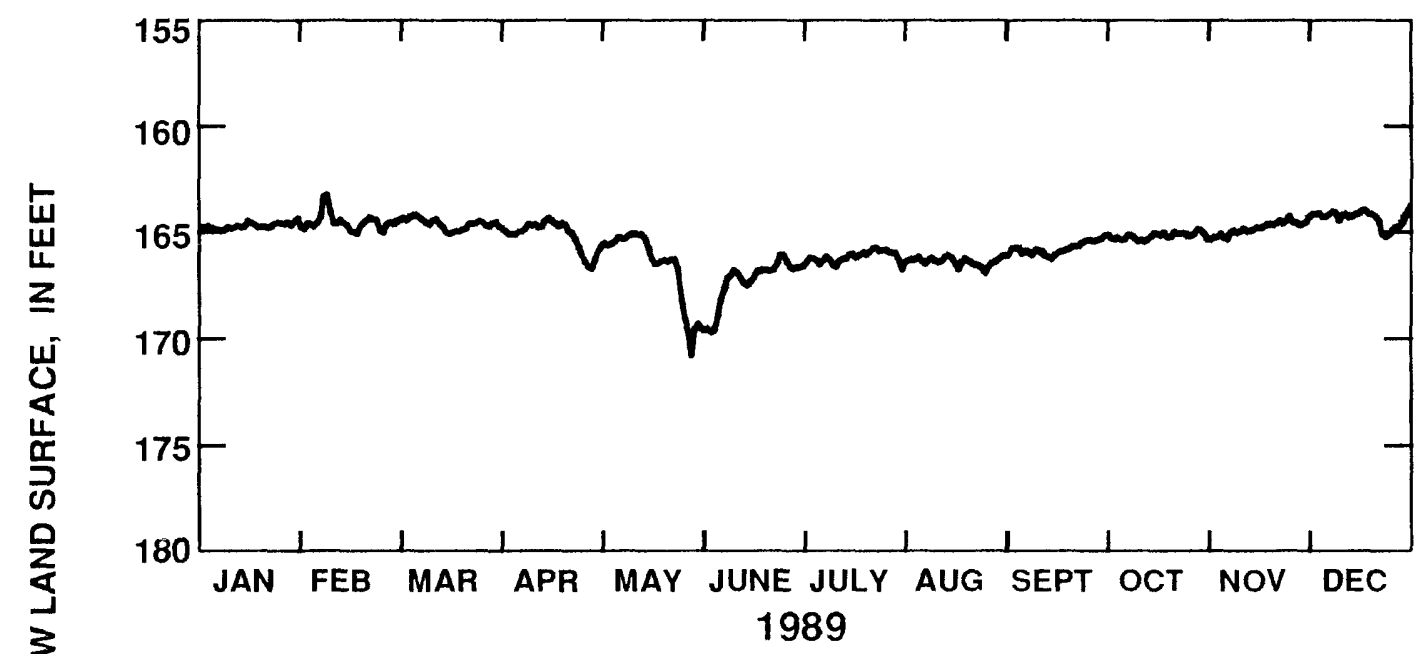

\begin{tabular}{|c|c|c|c|c|c|c|c|c|c|c|c|c|}
\hline 1989 & JAN & FEB & MAR & APR & MAY & JUN & JUL & $A \cup G$ & SEP & OCT & NOV & DEC \\
\hline $\begin{array}{l}\text { MEAN } \\
\text { MAX } \\
\text { MIN }\end{array}$ & $\begin{array}{l}164.76 \\
164.99 \\
164.40\end{array}$ & $\begin{array}{l}164.57 \\
165.13 \\
163.28\end{array}$ & $\begin{array}{l}164.66 \\
165.14 \\
164.25\end{array}$ & $\begin{array}{l}165.16 \\
166.77 \\
164.40\end{array}$ & $\begin{array}{l}166.53 \\
170.88 \\
165.14\end{array}$ & $\begin{array}{l}167.50 \\
169.78 \\
166.14\end{array}$ & $\begin{array}{l}166.24 \\
166.73 \\
165.80\end{array}$ & $\begin{array}{l}166.48 \\
167.00 \\
166.17\end{array}$ & $\begin{array}{l}165.87 \\
166.32 \\
165.39\end{array}$ & $\begin{array}{l}165.27 \\
165.55 \\
164.97\end{array}$ & $\begin{array}{l}164.94 \\
165.46 \\
164.35\end{array}$ & $\begin{array}{l}164.47 \\
165.32 \\
164.08\end{array}$ \\
\hline SAL & 1989 & & MEAN & 165.5 & & $\mathrm{HIGH}$ & 163.2 & & LOW & 170.8 & & \\
\hline
\end{tabular}

Figure 43.--Water level in observation well 26R001, Toombs County. 


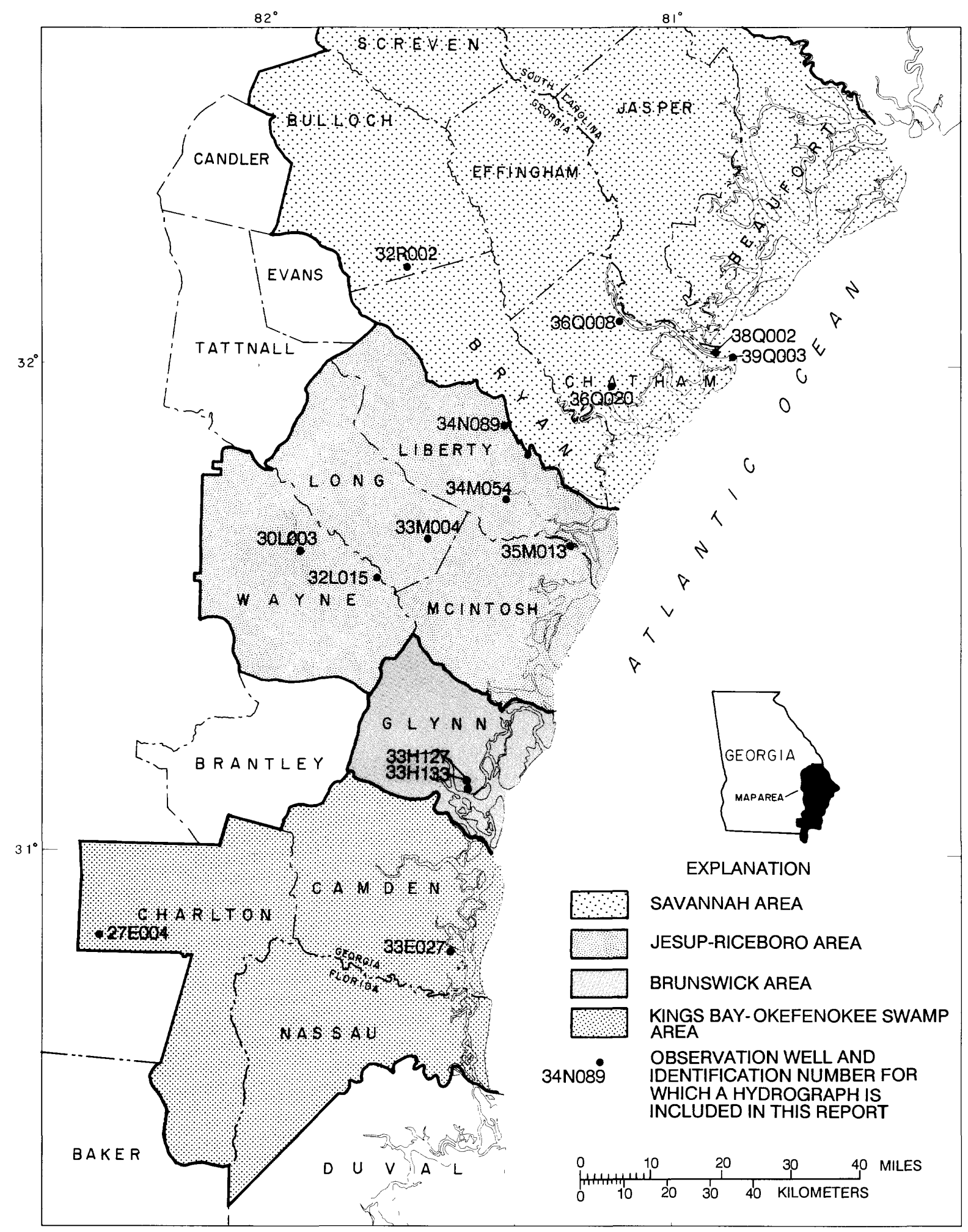

Figure 44.--Locations of observation wells completed in the Upper Floridan aquifer in the coastal area. 
320530081085001 Local number, 360008.

LOCATION.--Lat $32^{\circ} 05^{\prime} 30^{\prime \prime}$, long $81^{\circ} 08^{\prime} 50^{\prime \prime}$, Hydrologic Unit 03060204, 0.19 mi southeast of intersection of Alfred Street and U.S. Highway 80.

Owner: Layne-Atlantic Co.

AQUIFER.--Upper Floridan

WELL CHARACTERISTICS.--Drilled unused supply well, diameter 4 in., depth $406 \mathrm{ft}$, cased to $250 \mathrm{ft}$, open hole.

DATUM.--Altitude of land-surface datum is $9.91 \mathrm{ft}$.

Measuring point: Top of $3 \mathrm{in}$. casing, $1.0 \mathrm{ft}$ above land-surface datum.

REMARKS.--None.

PERIOD OF RECORD.--February 1954 to current year.

EXTREMES FOR PERIOD OF RECORD.--Highest water leve1, $49.17 \mathrm{ft}$ below land-surface datum, July 11 , 1954: lowest

$124.40 \mathrm{ft}$ below land-surface datum, August 30, 1980.

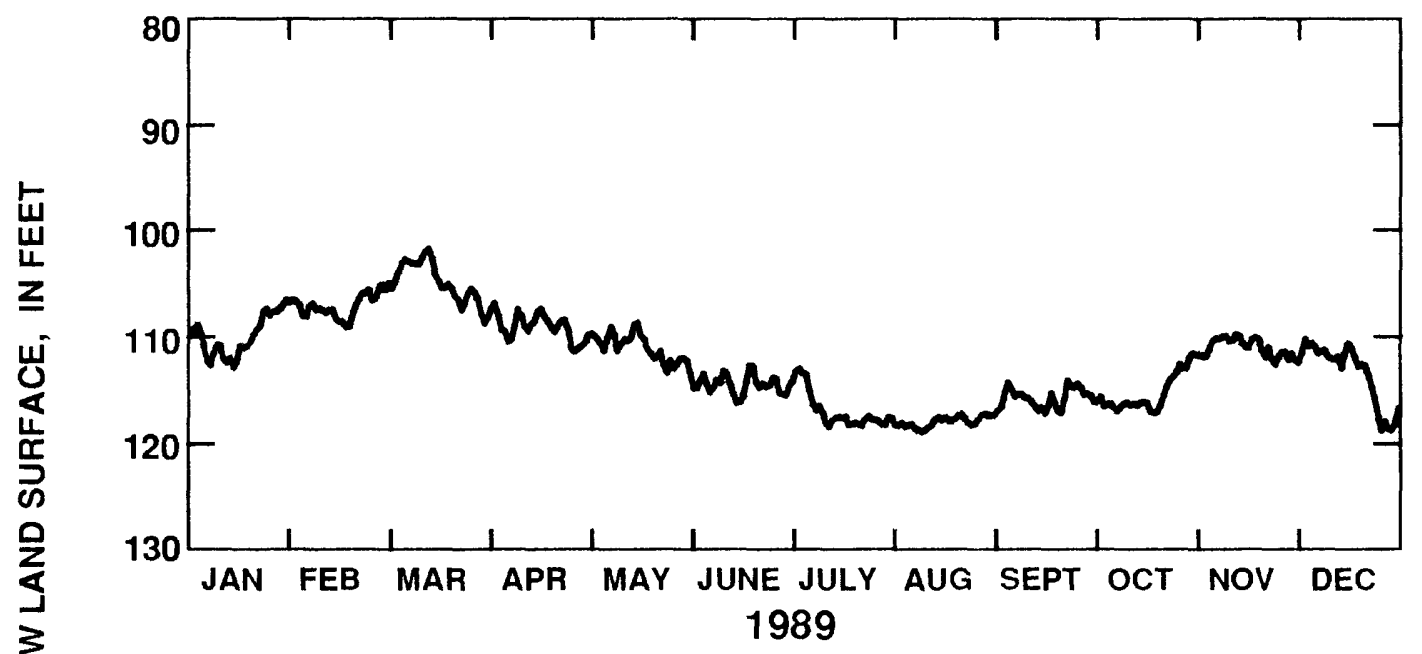

1989 JAN FEB MAR APR MAY JUN JUL AUG $S E P$ OCT NOV DEC

MEAN $109.70 \quad 107.10 \quad 104.84 \quad 109.08 \quad 111.09 \quad 114.56 \quad 117.03 \quad 118.09 \quad 115.87 \quad 115.44 \quad 111.17 \quad 113.62$

MAX $112.82 \quad 109.02 \quad 108.76 \quad 111.43 \quad 113.42 \quad 116.28 \quad 118.54 \quad 119.04 \quad 117.29 \quad 117.30 \quad 112.76 \quad 119.05$

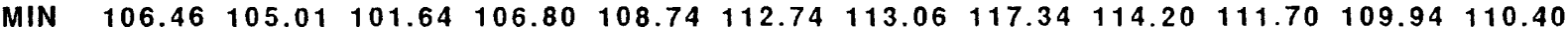

CAL YR 1989

MEAN 112.34

$\mathrm{HIGH} \quad 101.64$

LOW 119.05

Figure 45.--Water level in observation well 36Q008, Chatham County. 
320021081124801 Local number, 360020.

LOCATION.--Lat 32'00'18", long 81'12'48", Hydrologic Unit 03060204, 2.7 mi south of intersection of U.S. Highway 17 with Dean Forest Road.

Owner: H. J. Morrison.

AQUIFER.--Upper Floridan

WELL CHARACTERISTICS.--Drilled unused supply well, diameter $3 \mathrm{in}$., depth $365 \mathrm{ft}$, cased to $330 \mathrm{ft}$, open hole.

DATUM.--Altitude of land-surface datum is $13 \mathrm{ft}$.

Measuring point: Top of recorder shelf, $3.88 \mathrm{ft}$ above land-surface datum.

REMARKS.--Borehole geophysical survey, May 7, 1985. Water levels for period of missing record, January 4-23,

were estimated.

PERIOD OF RECORD.--March 1958 to current year.

EXTREMES FOR PERIOD OF RECORD.--Highest water level, $17.66 \mathrm{ft}$ below land-surface datum, June 28, 1958; lowest,

$54.45 \mathrm{ft}$ below land-surface datum, July 23, 1986.
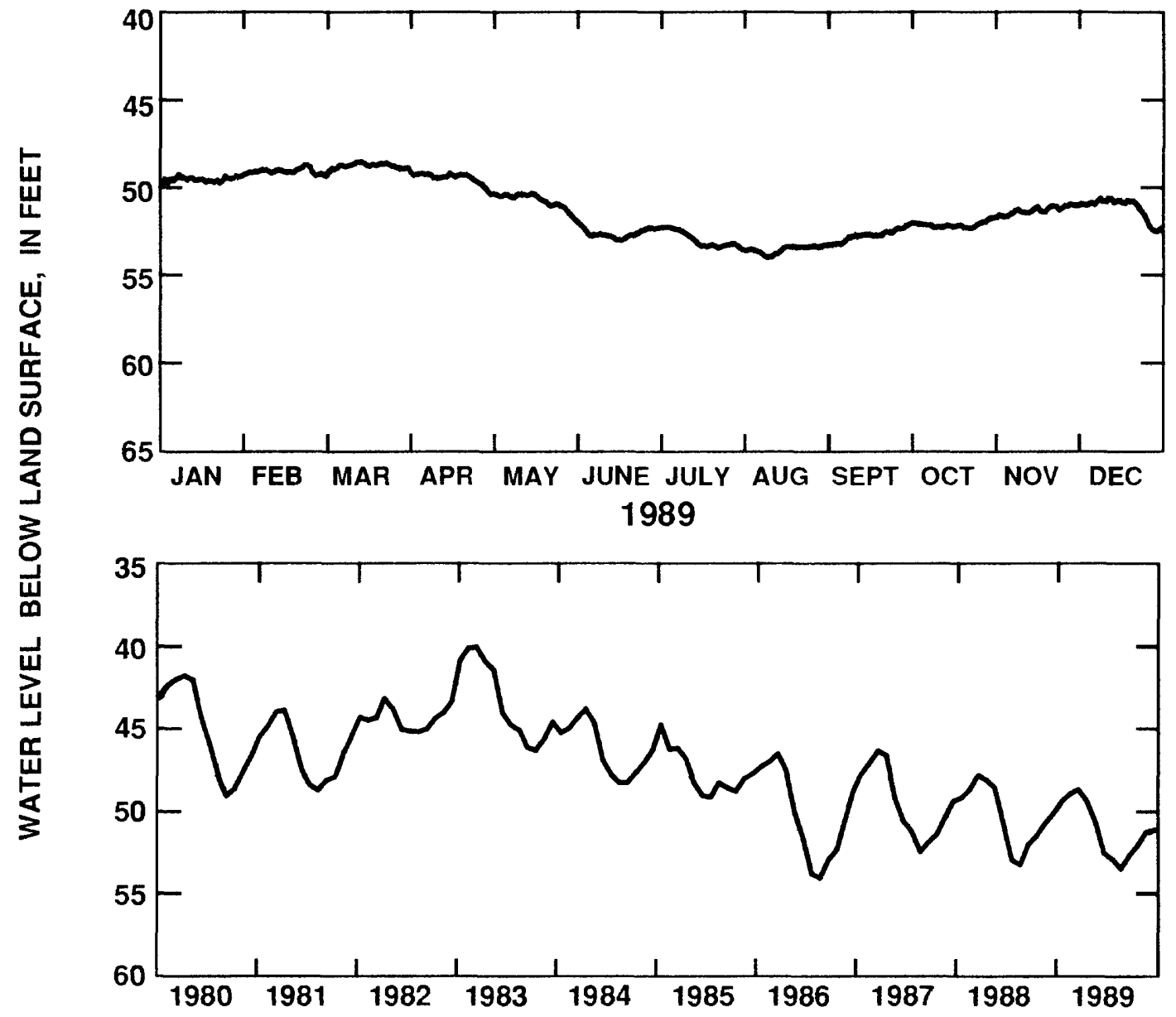

\begin{tabular}{|c|c|c|c|c|c|c|c|c|c|c|c|c|}
\hline 1989 & JAN & FEB & MAR & APR & MAY & JUN & JUL & $A \cup G$ & SEP & OCT & NOV & DEC \\
\hline $\begin{array}{l}\text { MEAN } \\
\text { MAX } \\
\text { MIN }\end{array}$ & $\begin{array}{l}49.44 \\
49.70 \\
49.13\end{array}$ & $\begin{array}{l}49.00 \\
49.28 \\
48.66\end{array}$ & $\begin{array}{l}48.73 \\
49.27 \\
48.48\end{array}$ & $\begin{array}{l}49.43 \\
50.37 \\
49.11\end{array}$ & $\begin{array}{l}50.72 \\
51.85 \\
50.32\end{array}$ & $\begin{array}{l}52.61 \\
53.02 \\
51.99\end{array}$ & $\begin{array}{l}52.98 \\
53.57 \\
52.26\end{array}$ & $\begin{array}{l}53.56 \\
54.01 \\
53.31\end{array}$ & $\begin{array}{l}52.75 \\
53.29 \\
52.14\end{array}$ & $\begin{array}{l}52.15 \\
52.35 \\
51.74\end{array}$ & $\begin{array}{l}51.33 \\
51.73 \\
51.00\end{array}$ & $\begin{array}{l}51.21 \\
52.55 \\
50.65\end{array}$ \\
\hline CAL Y & 1989 & & $A N$ & 51.17 & & GH & 48.48 & & ow & 54.01 & & \\
\hline
\end{tabular}

Figure 46.--Water level in observation well 36Q020, Chatham County. 
320202080541201 Local number, 380002.

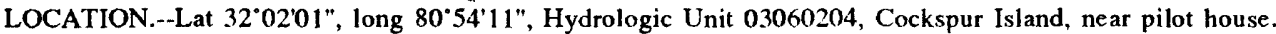

Owner: U.S. Department of the Interior, National Park Service test well 6.

AQUIFER.--Upper Floridan

WELL CHARACTERISTICS.--Drilled observation well, diameter 8 in., depth $348 \mathrm{ft}$, cased to $110 \mathrm{ft}$, open hole.

DATUM.--Altitude of land-surface datum is $8.0 \mathrm{ft}$.

Measuring point: Top of recorder shelf, $3.62 \mathrm{ft}$ above land-surface datum.

REMARKS.--Borehole geophysical survey conducted June 16, 1961.

PERIOD OF RECORD.--February 1956 to current year.

EXTREMES FOR PERIOD OF RECORD.--Highest water level, $16.00 \mathrm{ft}$ below land-surface datum, March 5, 1956; lowest,

$38.48 \mathrm{ft}$ below land-surface datum, August 4, 1986.

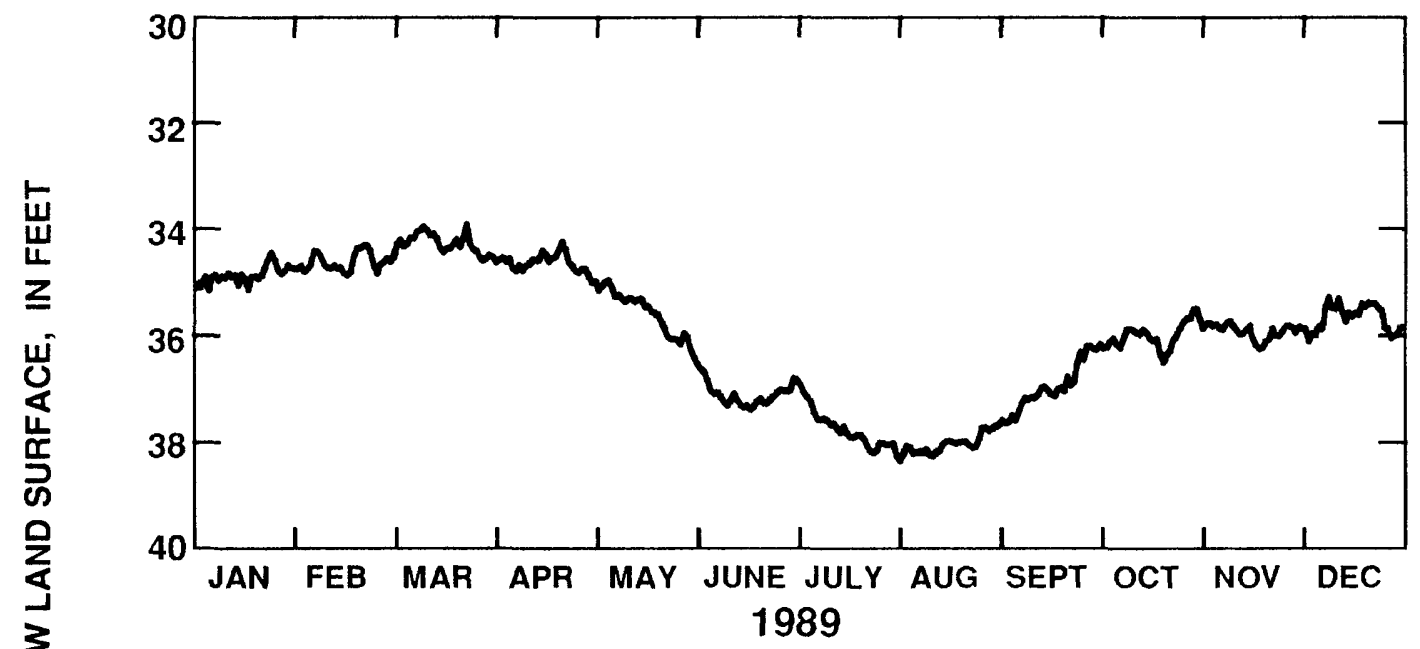

\begin{tabular}{|c|c|c|c|c|c|c|c|c|c|c|c|c|}
\hline 1989 & JAN & FEB & MAR & APR & MAY & JUN & JUL & $\mathbf{A U G}$ & SEP & OCT & NOV & DEC \\
\hline $\begin{array}{l}\text { MEAN } \\
\text { MAX } \\
\text { MIN }\end{array}$ & $\begin{array}{l}34.85 \\
35.15 \\
34.44\end{array}$ & $\begin{array}{l}34.62 \\
34.87 \\
34.31\end{array}$ & $\begin{array}{l}34.29 \\
34.61 \\
33.91\end{array}$ & $\begin{array}{l}34.64 \\
35.02 \\
34.25\end{array}$ & $\begin{array}{l}35.58 \\
36.41 \\
34.98\end{array}$ & $\begin{array}{l}37.12 \\
37.40 \\
36.54\end{array}$ & $\begin{array}{l}37.75 \\
38.28 \\
36.84\end{array}$ & $\begin{array}{l}38.05 \\
38.37 \\
37.70\end{array}$ & $\begin{array}{l}37.01 \\
37.66 \\
36.23\end{array}$ & $\begin{array}{l}36.03 \\
36.53 \\
35.54\end{array}$ & $\begin{array}{l}35.96 \\
36.29 \\
35.76\end{array}$ & $\begin{array}{l}35.71 \\
36.15 \\
35.32\end{array}$ \\
\hline CAL Y & 1989 & & MEAN & 35.98 & & HIGH & 33.91 & & LOW & 38.37 & & \\
\hline
\end{tabular}

Figure 47.--Water level in observation well $38 Q 002$, Chatham County. 
320122080510204 Local number, 39 Q003.

LOCATION.--Lat 32 $01^{\prime 22}$ ", long $80^{\circ} 51^{\prime} 01^{\prime \prime}$, Hydrologic Unit 03060204, Tybee Island near Fort Screven.

Owner: U.S. Geological Survey test well 7.

AQUIFER.--Upper Floridan aquifer.

WELL CHARACTERISTICS.--Drilled observation well, diameter $10 \mathrm{in}$., depth $600 \mathrm{ft}$, cased to $129 \mathrm{ft}$, open hole.

DATUM.--Altitude of land-surface datum is $7.0 \mathrm{ft}$.

Measuring point: Top of $10 \mathrm{in}$. casing, $2.0 \mathrm{ft}$ above land-surface datum.

REMARKS.--Borehole geophysical survey conducted January 24, 1962. Water levels for period of missing record,

October 18 to November 17, were estimated.

PERIOD OF RECORD.--May 1952 to current year.

EXTREMES FOR PERIOD OF RECORD.--Highest water level, $17.80 \mathrm{ft}$ below land-surface datum, April 11, 1963; lowest,

$34.33 \mathrm{ft}$ below land-surface datum, August $3,1986$.

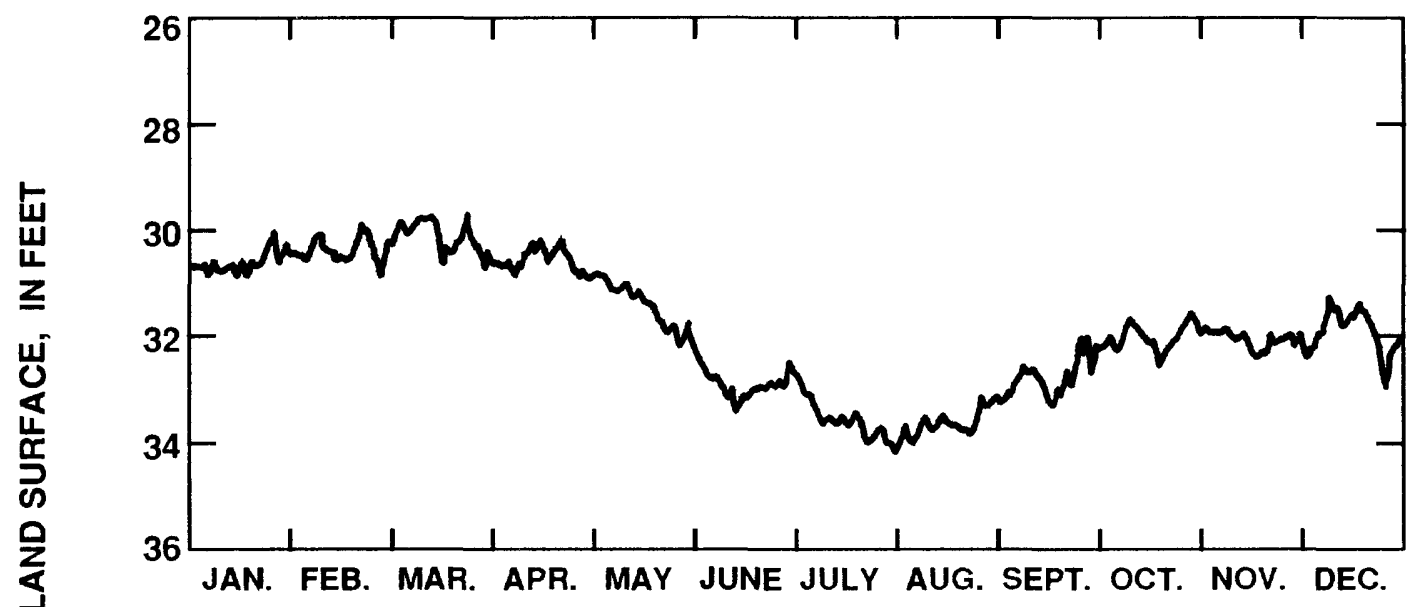
1989

\begin{tabular}{|c|c|c|c|c|c|c|c|c|c|c|c|c|}
\hline 1989 & JAN & FEB & MAR & APR & MAY & JUN & JUL & AUG & SEP & OCT & NOV & DEC \\
\hline $\begin{array}{l}\text { MEAN } \\
\text { MAX } \\
\text { MIN }\end{array}$ & $\begin{array}{l}30.58 \\
30.88 \\
30.03\end{array}$ & $\begin{array}{l}30.38 \\
30.90 \\
29.94\end{array}$ & $\begin{array}{l}30.15 \\
30.77 \\
29.66\end{array}$ & $\begin{array}{l}30.59 \\
30.94 \\
30.19\end{array}$ & $\begin{array}{l}31.43 \\
32.21 \\
30.74\end{array}$ & $\begin{array}{l}32.89 \\
33.34 \\
32.28\end{array}$ & $\begin{array}{l}33.56 \\
34.08 \\
32.55\end{array}$ & $\begin{array}{l}33.63 \\
34.12 \\
33.17\end{array}$ & $\begin{array}{l}32.77 \\
33.31 \\
32.04\end{array}$ & $\begin{array}{l}32.01 \\
32.53 \\
31.58\end{array}$ & $\begin{array}{l}32.06 \\
32.44 \\
31.85\end{array}$ & $\begin{array}{l}31.93 \\
32.95 \\
31.22\end{array}$ \\
\hline CAL $Y$ & 1989 & & MEAN & 31.84 & & $\mathrm{HIGH}$ & 29.66 & & Low & 34.12 & & \\
\hline
\end{tabular}

Figure 48.--Water level in observation well 39Q003, Chatham County. 
321240081411501 Local number, 32R002.

LOCATION.--Lat 32'12'40", long 81 41'15", Hydrologic Unit 03060202, 2.6 mi north along Ga. Highway 67 from the Bulloch-Bryan County line, approximately $100 \mathrm{ft}$ east of center line of road.

Owner: Georgia Geologic Survey, Bulloch South test well 1.

AQUIFER.--Upper Floridan

WELL CHARACTERISTICS.--Drilled observation well, diameter 6 in., depth $804 \mathrm{ft}$, cased to $420 \mathrm{ft}$, open hole.

DATUM.--Altitude of land-surface datum is $120 \mathrm{ft}$.

Measuring point: Top of recorder shelf, $3.0 \mathrm{ft}$ above land-surface datum.

REMARKS.--Borehole geophysical survey and well sounded August 1982.

PERIOD OF RECORD.--February 1983 to current year.

EXTREMES FOR PERIOD OF RECORD.--Highest water level, $85.08 \mathrm{ft}$ below land-surface datum, April 24, 1983; lowest, $92.72 \mathrm{ft}$ below land-surface datum, August 4, 1988 .
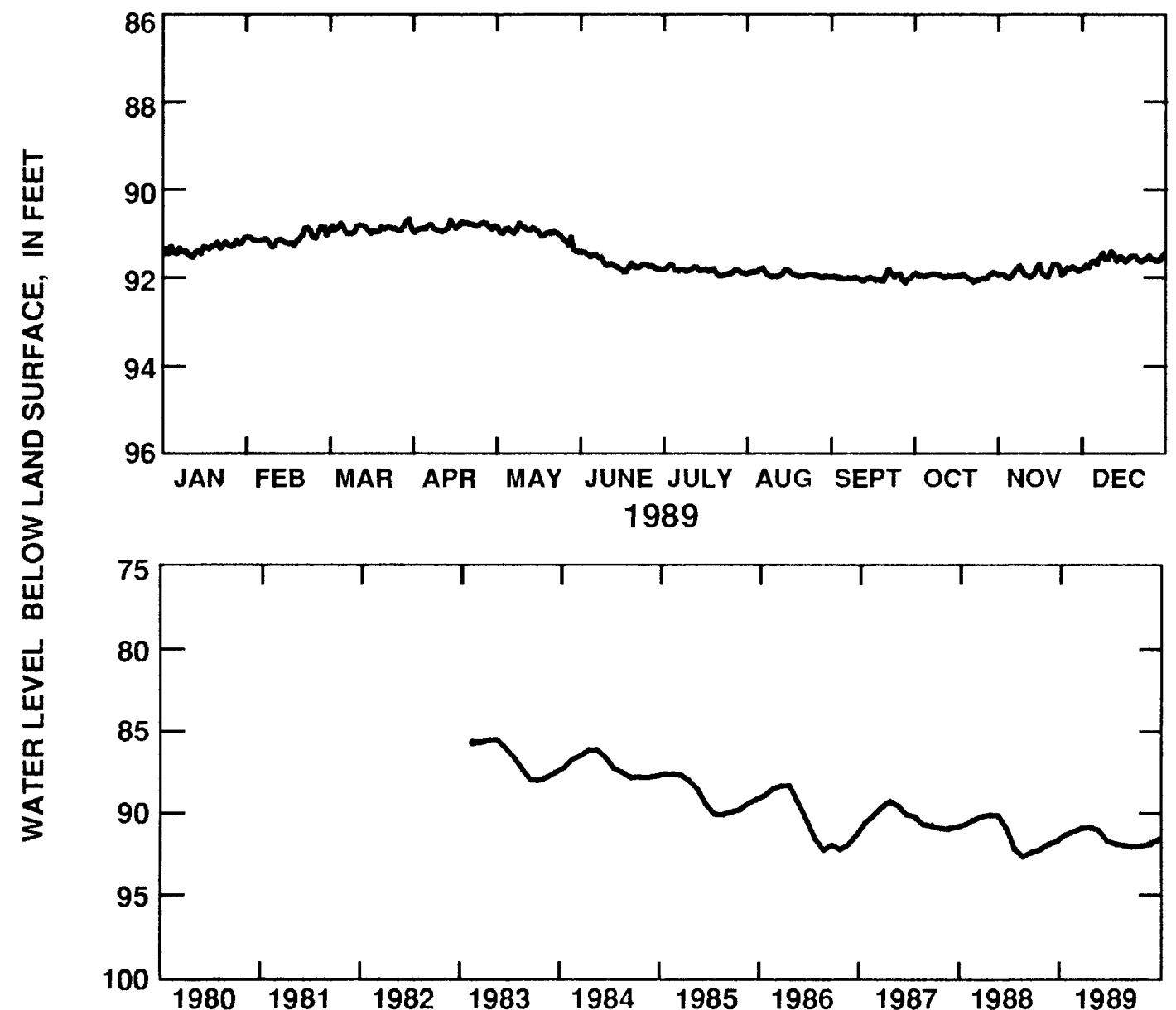

\begin{tabular}{|c|c|c|c|c|c|c|c|c|c|c|c|c|}
\hline 1989 & JAN & FEB & MAR & APR & MAY & JUN & JUL & AUG & SEP & $\mathrm{OCT}$ & NOV & DEC \\
\hline $\begin{array}{l}\text { MEAN } \\
\text { MAX } \\
\text { MIN }\end{array}$ & $\begin{array}{l}91.33 \\
91.53 \\
91.09\end{array}$ & $\begin{array}{l}91.12 \\
91.32 \\
90.86\end{array}$ & $\begin{array}{l}90.91 \\
91.05 \\
90.69\end{array}$ & $\begin{array}{l}90.87 \\
91.00 \\
90.72\end{array}$ & $\begin{array}{l}91.02 \\
91.44 \\
90.79\end{array}$ & $\begin{array}{l}91.70 \\
91.90 \\
91.45\end{array}$ & $\begin{array}{l}91.88 \\
92.00 \\
91.75\end{array}$ & $\begin{array}{l}91.97 \\
92.04 \\
91.83\end{array}$ & $\begin{array}{l}92.06 \\
92.17 \\
91.86\end{array}$ & $\begin{array}{l}92.03 \\
92.16 \\
91.94\end{array}$ & $\begin{array}{l}91.93 \\
92.07 \\
91.76\end{array}$ & $\begin{array}{l}91.66 \\
91.89 \\
91.48\end{array}$ \\
\hline CAL Y & 1989 & & MEAN & 91.54 & & HIGH & 90.69 & & LOW & 92.17 & & \\
\hline
\end{tabular}

Figure 49.--Water level in observation well 32R002, Bulloch County. 


\section{Jesup-Riceboro Area}

The water level in the Upper Floridan aquifer in the Jesup-Riceboro area is monitored in six wells, all of which are included in this report (figs. 50-55). In this area, water levels in wells tapping the aquifer are affected mainly by industrial pumping at Doctortown (near Jesup) and at Riceboro, and to a lesser extent by pumping in the Savannah area. In 1987, pumpage was about $74 \mathrm{Mgal} / \mathrm{d}$ at Doctortown and about $16 \mathrm{Mgal} / \mathrm{d}$ at Riceboro (Trent and others, 1990). Hydrographs for wells 30L003 (fig. 50), 32L015 (fig. 51), 33M004 (fig. 52) and 34M054 (fig. 53) illustrate the effects that a partial industrial shutdown had on the water levels in the JesupRiceboro area in May 1989. The water levels in wells 34N089 (fig. 54) and 35M013 (fig. 55) were not affected by the industrial shutdowns because these wells are farther from the centers of pumping.

In the Jesup-Riceboro area, a general downward water-level trend in the Upper Floridan aquifer has been monitored since 1983. Mean water levels in six wells were from 0.1 to $1.3 \mathrm{ft}$ lower in 1989 than in 1988 , and record low water levels were measured in wells 30L003, 32L015, 33M004, and 35M013 (figs. 50-52 and 55) during August, September, and December 1989. These declines continued the downward trend that began in 1983 , and may be attributed to regional pumping and below-normal precipitation.

\section{Kings Bay-Okefenokee Swamp area}

The water level in the Upper Floridan aquifer in the Kings Bay area is monitored in two wells, both of which are included in this report (figs. 56 and 57). Water levels in wells tapping the aquifer in this area are affected by industrial pumping totaling about $34 \mathrm{Mgal} / \mathrm{d}$ at St Marys, Ga. (Trent and others, 1990), and about $37 \mathrm{Mgal} / \mathrm{d}$ at Fernandina Beach, Fla. (Marella, 1986). Pumping in these areas has resulted in the formation of a cone of depression centered at Fernandina Beach, Fla., and to a lesser extent at St Marys, Ga.

The mean water level in well 33E027 (fig. 56) at Kings Bay was $0.8 \mathrm{ft}$ lower in 1989 than in 1988, and in well 27E004 (fig. 57) in western Charlton County, the mean water level was $1.6 \mathrm{ft}$ lower in 1989 than in 1988. A record low water level was measured in well 27E004 in June 1989. These declines continued the general downward water-level trend in the area since 1983, and may be attributed to increased regional pumping and below-normal precipitation.

\section{Brunswick Area}

The water level in the Upper Floridan aquifer in the Brunswick area is monitored in six wells, two of which are included in this report (figs. 58 and 59). In this area, the water level in wells tapping the aquifer is affected primarily by industrial pumping, which totalled about $70 \mathrm{Mgal} / \mathrm{d}$ in 1987 (Trent and others, 1990). This pumping has resulted in the development of a cone of depression centered at Brunswick. The water-level response to pumping is illustrated on the hydrographs for wells $33 \mathrm{H} 127$ tapping the lower water-bearing zone of the upper Floridan aquifer (fig. 58), and well 33H133 tapping the upper water-bearing zone of the upper Floridan aquifer (fig. 59). In 1989, reduced pumping related to partial industrial shutdowns are reflected by sharp water-level rises during May and October. The mean water levels in wells $33 \mathrm{H} 133$ and $33 \mathrm{H} 127$ were 1.3 and $1.7 \mathrm{ft}$ lower in 1989 than in 1988, respectively. These declines continued the downward trend in the area since 1983. 
313701081543501 Local number, 30L003.

LOCATION.--Lat $31^{\circ} 37^{\prime} 01^{\prime \prime}$, long $81^{\circ}$ '54'34", Hydrologic Unit 03070106, about 0.5 mi west of Jesup city limits near intersection of U.S. Highway 341 and Sunset Drive.

Owner: City of Jesup Housing Authority.

AQUIFER.--Upper Floridan

WELL CHARACTERISTICS.--Drilled unused supply well, diameter 4 in., depth $584 \mathrm{ft}$, cased to $472 \mathrm{ft}$, open hole.

DATUM.--Altitude of land-surface datum is $107 \mathrm{ft}$.

Measuring point: Top of recorder shelf, $2.88 \mathrm{ft}$ above land-surface datum.

REMARKS.--Borehole geophysical survey conducted August 19, 1963. Water levels for period of missing record,

June 3-14, were estimated.

PERIOD OF RECORD.--January 1964 to March 1967. February 1976 to current year.

EXTREMES FOR PERIOD OF RECORD.--Highest water level, $59.98 \mathrm{ft}$ below land-surface datum, April 19, 1964; lowest, $85.89 \mathrm{ft}$ below land-surface datum, August 10, 1989.

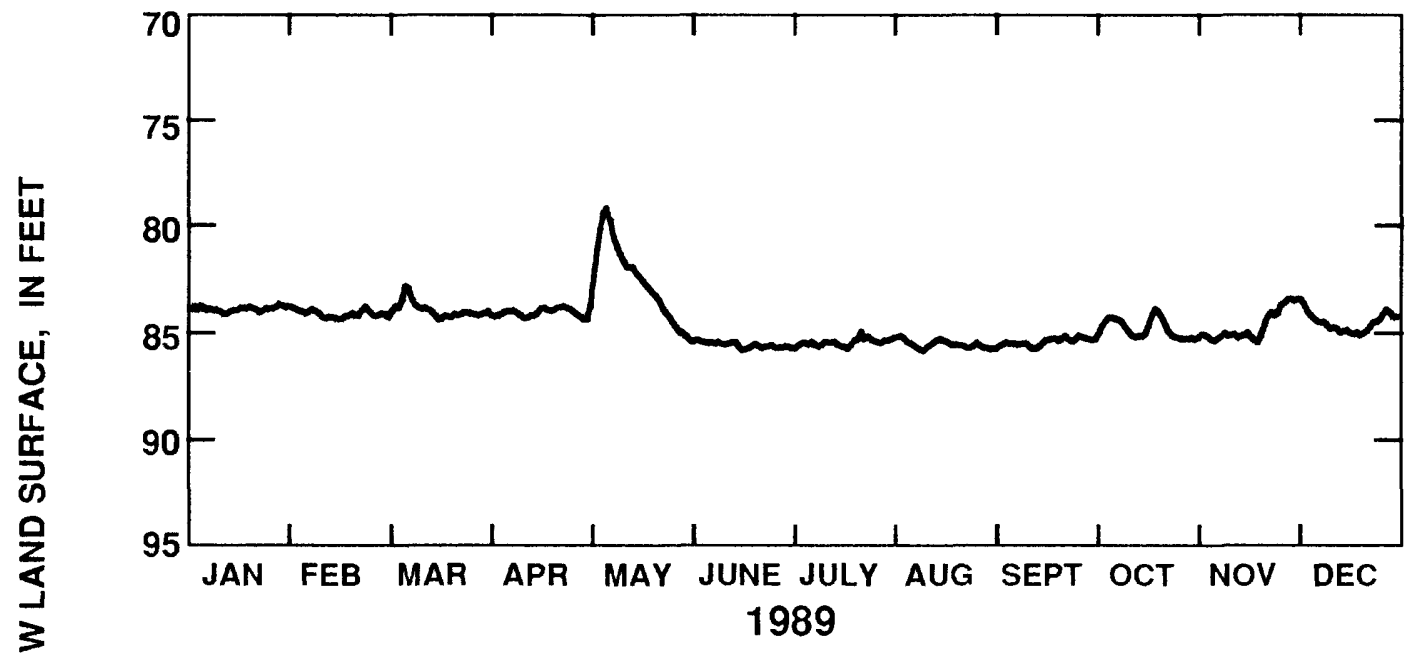

岂

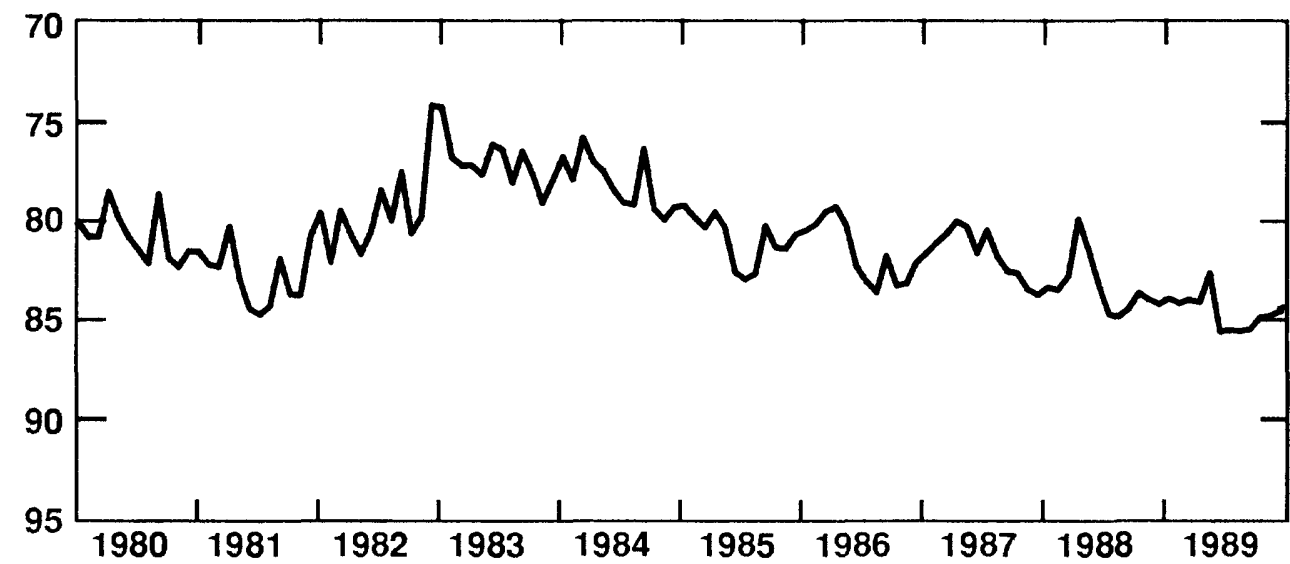

\begin{tabular}{|c|c|c|c|c|c|c|c|c|c|c|c|c|}
\hline 1989 & JAN & FEB & MAR & APR & MAY & JUN & JUL & AUG & SEP & OCT & NOV & DEC \\
\hline $\begin{array}{l}\text { MEAN } \\
\text { MAX } \\
\text { MIN }\end{array}$ & $\begin{array}{l}83.94 \\
84.18 \\
83.72\end{array}$ & $\begin{array}{l}84.17 \\
84.40 \\
83.82\end{array}$ & $\begin{array}{l}84.00 \\
84.44 \\
82.84\end{array}$ & $\begin{array}{l}84.11 \\
84.43 \\
83.82\end{array}$ & $\begin{array}{l}82.64 \\
85.35 \\
79.18\end{array}$ & $\begin{array}{l}85.63 \\
85.87 \\
85.40\end{array}$ & $\begin{array}{l}85.52 \\
85.81 \\
85.00\end{array}$ & $\begin{array}{l}85.60 \\
85.89 \\
85.20\end{array}$ & $\begin{array}{l}85.49 \\
85.81 \\
85.19\end{array}$ & $\begin{array}{l}84.87 \\
85.38 \\
83.94\end{array}$ & $\begin{array}{l}84.81 \\
85.52 \\
83.48\end{array}$ & $\begin{array}{l}84.56 \\
85.17 \\
83.49\end{array}$ \\
\hline SAL YF & 1989 & & MEAN & 84.61 & & $\mathrm{HIGH}$ & 79.18 & & LOW & 85.89 & & \\
\hline
\end{tabular}

Figure 50.--Water level in observation well 30L003, Wayne County. 
313253081433502 Local number, 32L015.

LOCATION.--Lat $31^{\circ} 32^{\prime} 52^{\prime \prime}$, long $81^{\circ} 43^{\prime} 36^{\prime \prime}$, Hydrologic Unit 03070106 , westernmost of three recorder wells, 0.8 mi north of

Gardi Road, on right side of dirt road, 4.3 mi east of Gardi.

Owner: Georgia Geologic Survey, Gardi test well 1.

AQUIFER.--Upper Floridan

WELL CHARACTERISTICS.--Drilled observation well, diameter 4 in., depth $750 \mathrm{ft}$, cased to $545 \mathrm{ft}$, open hole.

DATUM.--Altitude of land-surface datum is $74 \mathrm{ft}$.

Measuring point: Top of recorder shelf, $4.0 \mathrm{ft}$ above land-surface datum.

REMARKS.--Borehole geophysical survey conducted April 20, 1983.

PERIOD OF RECORD.--April 20, 1983 to current year.

EXTREMES FOR PERIOD OF RECORD.--Highest water level, $49.12 \mathrm{ft}$ below land-surface datum, March 19, 1984; lowest,

$61.29 \mathrm{ft}$ below land-surface datum, August 10, 1989 .

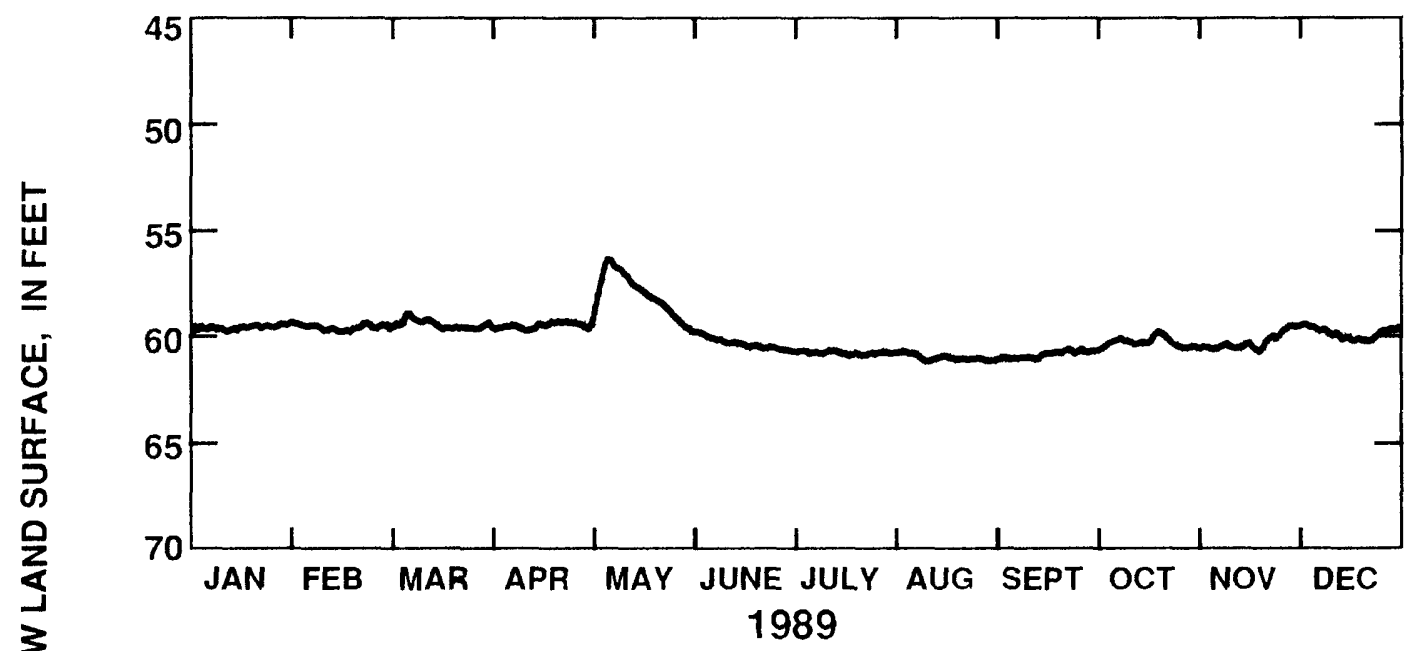

岃

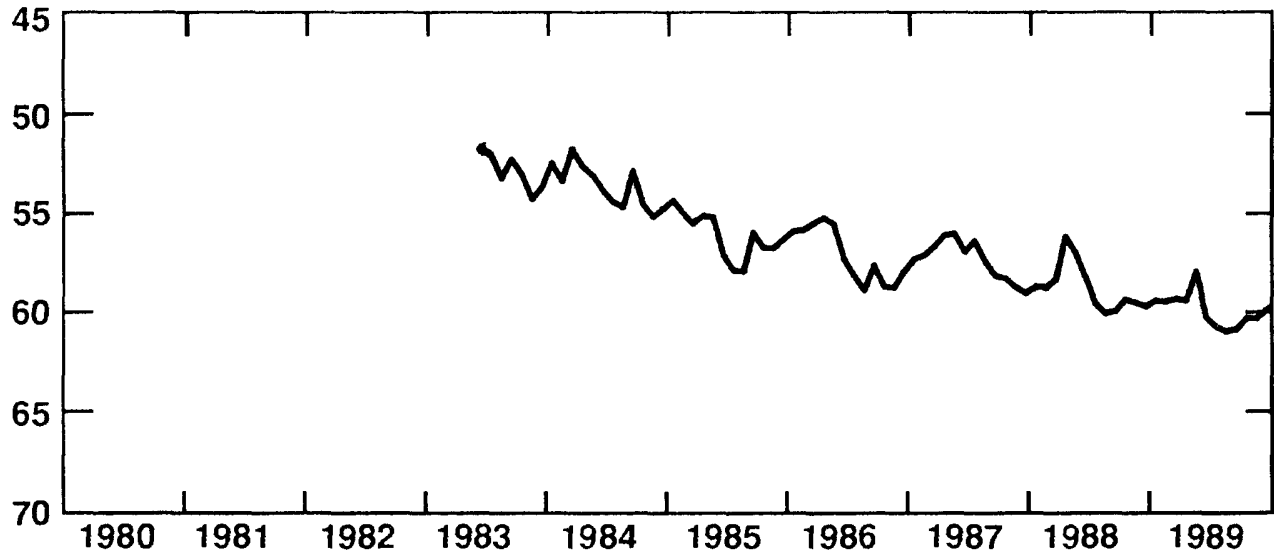

\begin{tabular}{|c|c|c|c|c|c|c|c|c|c|c|c|c|}
\hline 1989 & JAN & FEB & MAR & APR & MAY & JUN & JUL & AUG & SEP & OCT & NOV & DEC \\
\hline $\begin{array}{l}\text { MEAN } \\
\text { MAX } \\
\text { MIN }\end{array}$ & $\begin{array}{l}59.56 \\
59.77 \\
59.35\end{array}$ & $\begin{array}{l}59.59 \\
59.79 \\
59.38\end{array}$ & $\begin{array}{l}59.47 \\
59.71 \\
58.93\end{array}$ & $\begin{array}{l}59.54 \\
59.78 \\
59.36\end{array}$ & $\begin{array}{l}58.10 \\
59.81 \\
56.34\end{array}$ & $\begin{array}{l}60.41 \\
60.77 \\
59.88\end{array}$ & $\begin{array}{l}60.89 \\
61.03 \\
60.77\end{array}$ & $\begin{array}{l}61.12 \\
61.29 \\
60.84\end{array}$ & $\begin{array}{l}61.01 \\
61.21 \\
60.75\end{array}$ & $\begin{array}{l}60.44 \\
60.79 \\
59.93\end{array}$ & $\begin{array}{l}60.46 \\
60.90 \\
59.68\end{array}$ & $\begin{array}{l}60.04 \\
60.43 \\
59.61\end{array}$ \\
\hline$A L$ & & & MEAN & 60.05 & & $\mathrm{HIGH}$ & 56.34 & & LOW & 61.29 & & \\
\hline
\end{tabular}

Figure 51.--Water level in observation well 32L015, Wayne County. 
313845081361701 Local number, 33M004.

LOCATION.--Lat 31 38'54", long $81^{\circ} 36^{\prime} 04^{\prime \prime}$, Hydrologic Unit 03070106, 9.0 mi southeast of Ludowici, at Hope Cemetery.

Owner: U.S. Geological Survey test well 3.

AQUIFER.--Upper Floridan

WELL CHARACTERISTICS.--Drilled observation well, diameter 4-3 in., depth $872 \mathrm{ft}$, cased to $538 \mathrm{ft}$, open hole.

DATUM.--Altitude of land-surface datum is $61.2 \mathrm{ft}$.

Measuring point: Top of recorder shelf, $3.5 \mathrm{ft}$ above land-surface datum.

REMARKS.--Well pumped and sounded June 17, 1976, to depth of $861 \mathrm{ft}$ : water-quality sample collected. Borehole geophysical survey conducted July $28,1976$.

PERIOD OF RECORD.--January 1968 to current year.

EXTREMES FOR PERIOD OF RECORD.--Highest water level, $34.04 \mathrm{ft}$ below land-surface datum, January 14,1968 ; lowest, $55.74 \mathrm{ft}$ below land-surface datum, September $5,1989$.
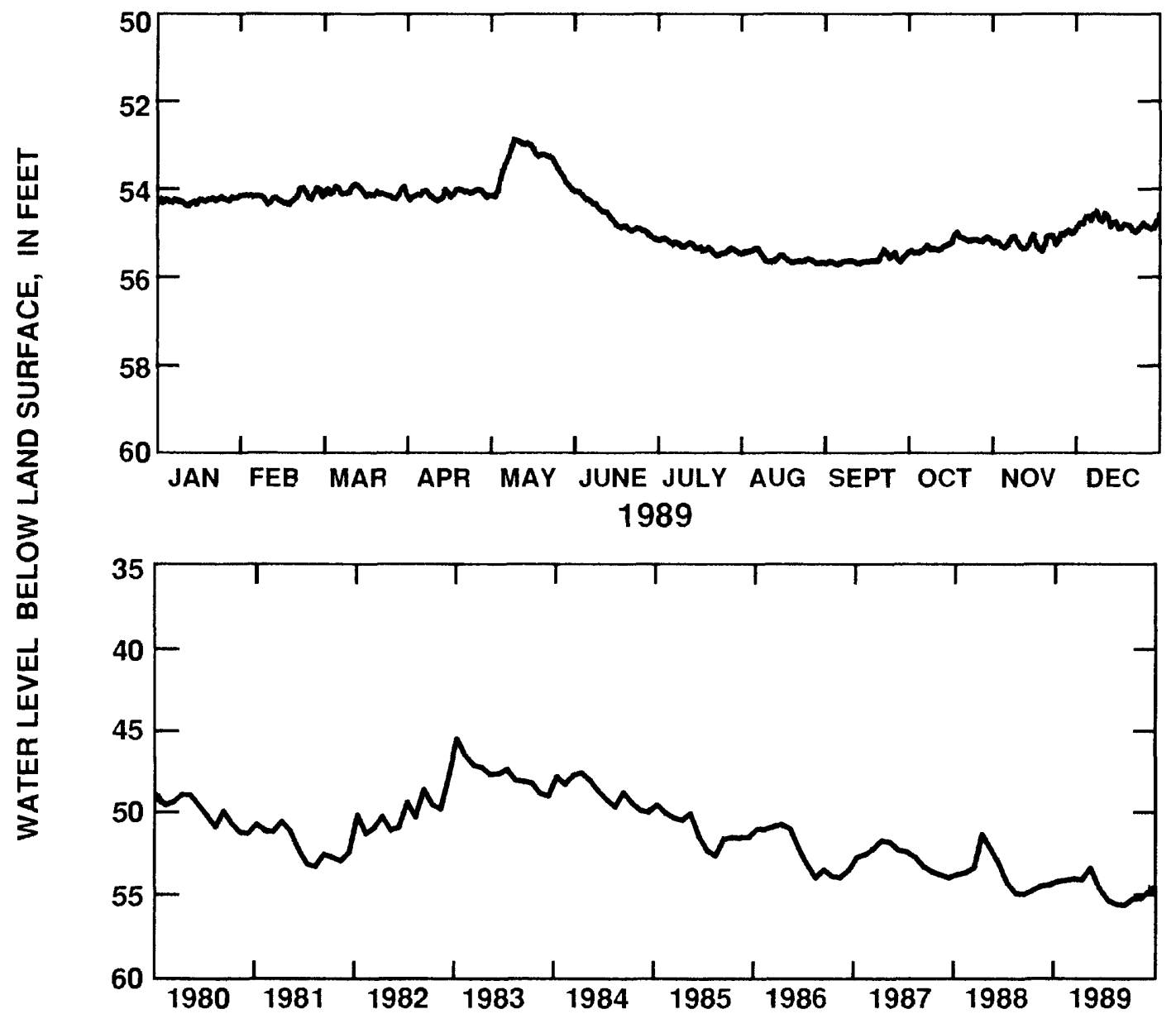

\begin{tabular}{|c|c|c|c|c|c|c|c|c|c|c|c|c|}
\hline 1989 & JAN & FEB & MAR & APR & MAY & JUN & JUL & AUG & SEP & OCT & NOV & DEC \\
\hline $\begin{array}{l}\text { MEAN } \\
\text { MAX } \\
\text { MIN }\end{array}$ & $\begin{array}{l}54.23 \\
54.36 \\
54.12\end{array}$ & $\begin{array}{l}54.16 \\
54.34 \\
53.95\end{array}$ & $\begin{array}{l}54.06 \\
54.21 \\
53.87\end{array}$ & $\begin{array}{l}54.10 \\
54.26 \\
53.99\end{array}$ & $\begin{array}{l}53.40 \\
54.16 \\
52.85\end{array}$ & $\begin{array}{l}54.63 \\
55.14 \\
54.04\end{array}$ & $\begin{array}{l}55.33 \\
55.53 \\
55.14\end{array}$ & $\begin{array}{l}55.59 \\
55.71 \\
55.37\end{array}$ & $\begin{array}{l}55.64 \\
55.74 \\
55.41\end{array}$ & $\begin{array}{l}55.28 \\
55.48 \\
55.02\end{array}$ & $\begin{array}{l}55.22 \\
55.45 \\
54.99\end{array}$ & $\begin{array}{l}54.83 \\
55.02 \\
54.55\end{array}$ \\
\hline AL & 1989 & & MEAN & 54.71 & & $\mathrm{HIGH}$ & 52.85 & & LOW & 55.74 & & \\
\hline
\end{tabular}

Figure 52.--Water level in observation well 33M004, Long County. 
314343081251901 Local number, 34M054.

LOCATION.--Lat $31^{\circ} 43^{\prime} 43^{\prime \prime}$, long $81^{\circ} 25^{\prime} 19^{\prime \prime}$, Hydrologic Unit 03060204, Riceboro, near entrance to Interstate Paper Company.

Owner: U.S. Geological Survey test well 2.

AQUIFER.--Upper Floridan

WELL CHARACTERISTICS.--Drilled observation well, diameter 4 in., depth $802 \mathrm{ft}$, cased to $467 \mathrm{ft}$, open hole.

DATUM.--Altitude of land-surface datum is $19 \mathrm{ft}$.

Measuring point: Top of recorder shelf, $3.4 \mathrm{ft}$ above land-surface datum.

REMARKS..-Well pumped July 11, 1979: water-quality sample collected at conclusion of pumping. Borehole geophysical

survey conducted June 15, 1976. Water levels for period of missing record, June 15-25, were estimated.

PERIOD OF RECORD.--February 1967 to current year.

EXTREMES FOR PERIOD OF RECORD.--Highest water level, $0.85 \mathrm{ft}$ below land-surface datum, February 5,1967 ; lowest,

$27.59 \mathrm{ft}$ below land-surface datum, September 16-17, 1988.

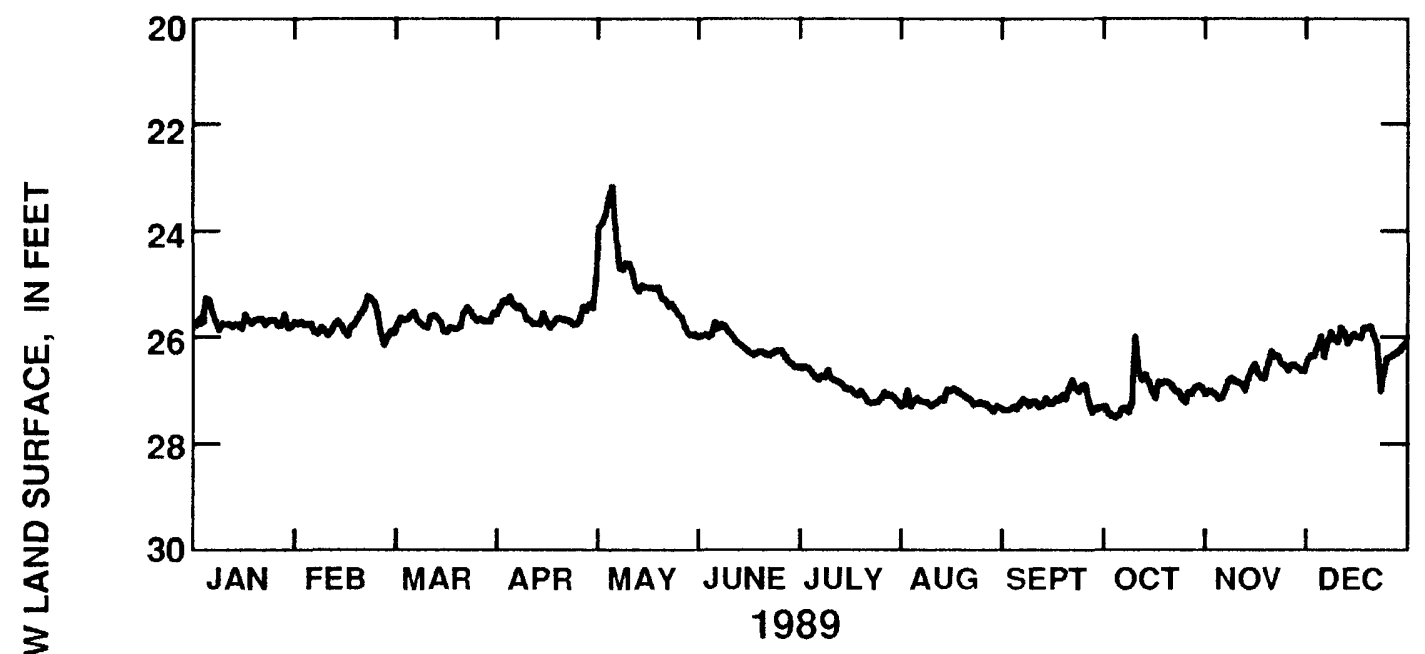

耑

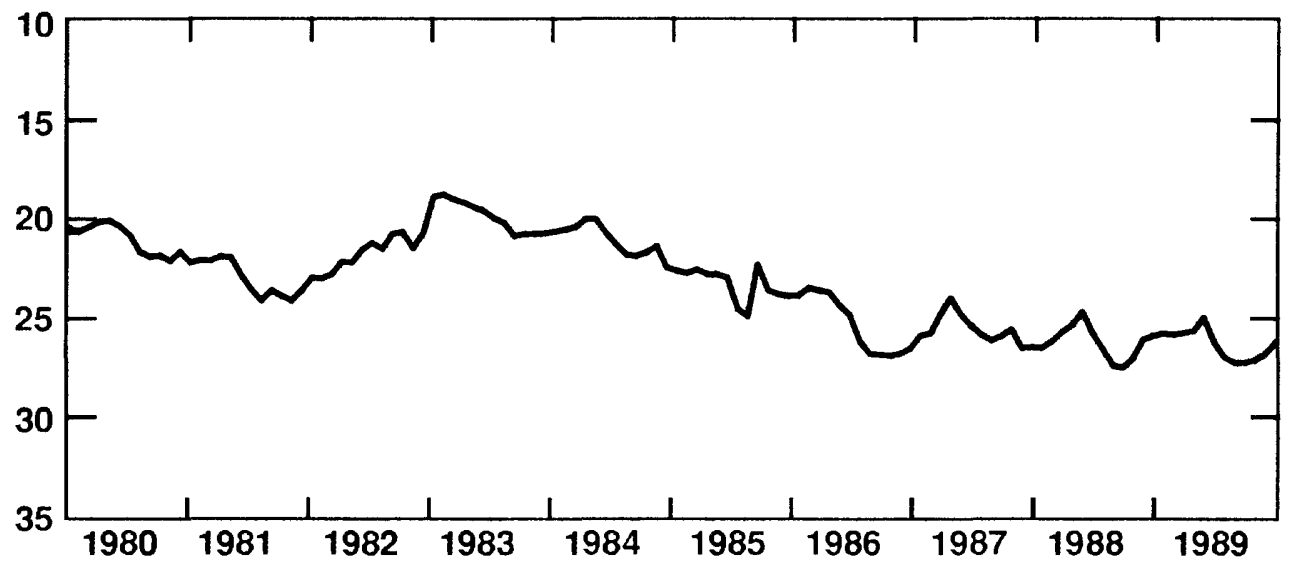

\begin{tabular}{|c|c|c|c|c|c|c|c|c|c|c|c|c|}
\hline 1989 & JAN & FEB & MAR & APR & MAY & JUN & JUL & AUG & SEP & OCT & NOV & DEC \\
\hline $\begin{array}{l}\text { MEAN } \\
\text { MAX } \\
\text { MIN }\end{array}$ & $\begin{array}{l}25.70 \\
25.86 \\
25.26\end{array}$ & $\begin{array}{l}25.75 \\
26.15 \\
25.24\end{array}$ & $\begin{array}{l}25.70 \\
25.92 \\
25.45\end{array}$ & $\begin{array}{l}25.59 \\
25.83 \\
25.25\end{array}$ & $\begin{array}{l}24.93 \\
25.98 \\
23.16\end{array}$ & $\begin{array}{l}26.17 \\
26.58 \\
25.74\end{array}$ & $\begin{array}{l}26.94 \\
27.25 \\
26.58\end{array}$ & $\begin{array}{l}27.21 \\
27.41 \\
26.98\end{array}$ & $\begin{array}{l}27.21 \\
27.44 \\
26.84\end{array}$ & $\begin{array}{l}27.08 \\
27.53 \\
26.01\end{array}$ & $\begin{array}{l}26.77 \\
27.19 \\
26.30\end{array}$ & $\begin{array}{l}26.21 \\
27.05 \\
25.84\end{array}$ \\
\hline CAL & 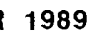 & & MEAN & 26.27 & & $\mathrm{HIGH}$ & 23.16 & & LOW & 27.53 & & \\
\hline
\end{tabular}

Figure 53.--Water level in observation well 34M054, Liberty County. 
315214081235301 Local number, 34N089.

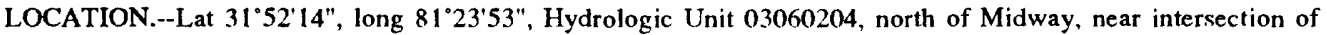

Ga. Highway 196 and U.S. Highway 17.

Owner: U.S. Geological Survey test well 1.

AQUIFER.--Upper Floridan

WELL CHARACTERISTICS.--Drilled observation well, diameter 4 in., depth $789 \mathrm{ft}$, cased to $410 \mathrm{ft}$, open hole.

DATUM.--Altitude of land-surface datum is $17 \mathrm{ft}$.

Measuring point: Top of 4 in. casing, $1.33 \mathrm{ft}$ above land-surface datum.

REMARKS.--Well pumped July 1I, 1979; water-quality sample collected at conclusion of pumping. Borehole geophysical survey conducted June 15, 1976. Water levels for periods of missing record, April 1 to May 2, and May 12-26, were estimated.

PERIOD OF RECORD.--February 1967 to current year.

EXTREMES FOR PERIOD OF RECORD.--Highest water level, $2.34 \mathrm{ft}$ below land-surface datum. March 6, 1967: lowest, $25.82 \mathrm{ft}$ below land-surface datum, August S, 1988.

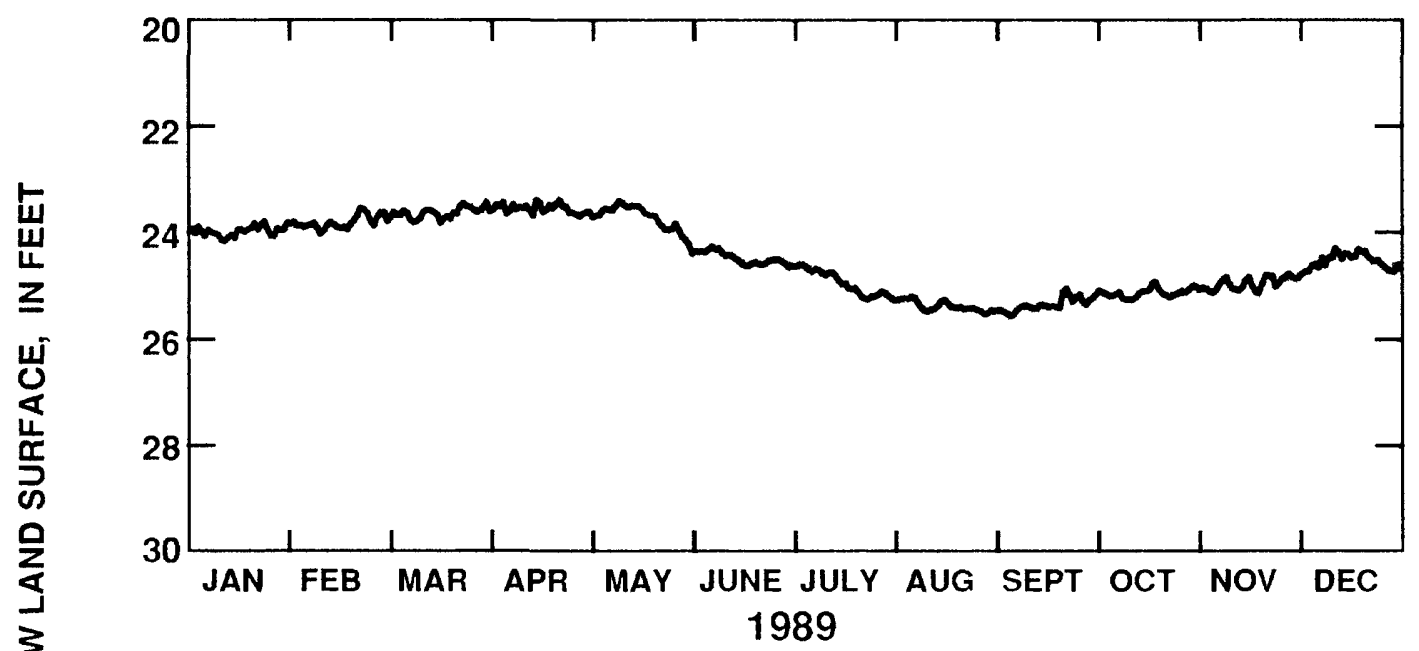

耑

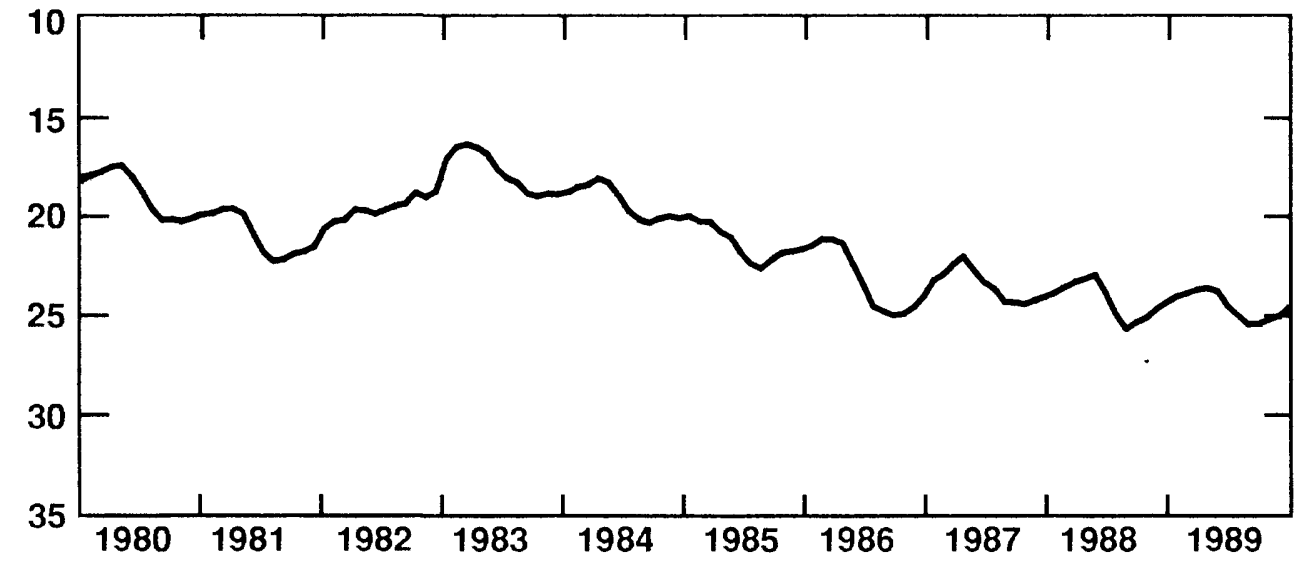

\begin{tabular}{|c|c|c|c|c|c|c|c|c|c|c|c|c|}
\hline 1989 & JAN & FEB & MAR & APR & MAY & JUN & JUL & AUG & SEP & OCT & NOV & DEC \\
\hline $\begin{array}{l}\text { MEAN } \\
\text { MAX } \\
\text { MIN }\end{array}$ & $\begin{array}{l}23.99 \\
24.18 \\
23.80\end{array}$ & $\begin{array}{l}23.83 \\
24.04 \\
23.55\end{array}$ & $\begin{array}{l}23.65 \\
23.84 \\
23.44\end{array}$ & $\begin{array}{l}23.57 \\
23.72 \\
23.39\end{array}$ & $\begin{array}{l}23.72 \\
24.24 \\
23.42\end{array}$ & $\begin{array}{l}24.51 \\
24.68 \\
24.30\end{array}$ & $\begin{array}{l}24.97 \\
25.28 \\
24.63\end{array}$ & $\begin{array}{l}25.41 \\
25.56 \\
25.24\end{array}$ & $\begin{array}{l}25.40 \\
25.60 \\
25.09\end{array}$ & $\begin{array}{l}25.17 \\
25.30 \\
24.98\end{array}$ & $\begin{array}{l}25.01 \\
25.18 \\
24.82\end{array}$ & $\begin{array}{l}24.59 \\
24.89 \\
24.34\end{array}$ \\
\hline CAL Y & 1989 & & MEAN & 24.49 & & $\mathrm{HIGH}$ & 23.39 & & LOW & 25.60 & & \\
\hline
\end{tabular}

Figure 54.--Water level in observation well 34N089, Liberty County. 
313823081154201 Local number, 35M013.

LOCATION.--Lat 31 $38^{\prime} 23^{\prime \prime}$, long $81^{\circ} 15^{\prime} 42^{\prime \prime}$, Hydrologic Unit $03060204,8.5$ mi east of U.S. Highway 17 at Harris Neck Wildlife Refuge.

Owner: U.S. Department of the Interior, Fish and Wildlife Service.

AQUIFER.--Upper Floridan

WELL CHARACTERISTICS.--Drilled unused supply well, diameter 10 in., depth $553 \mathrm{ft}$, cased to $376 \mathrm{ft}$, open hole.

DATUM.--Altitude of land-surface datum is $16.3 \mathrm{ft}$.

Measuring point: Top of recorder shelf, $3.2 \mathrm{ft}$ above land-surface datum.

REMARKS.--Well pumped August 3, 1976; water-quality sample collected at conclusion of pumping. Borehole geophysical

survey conducted June 16, 1976. Water levels for period of missing record, December 13-20, were estimated.

PERIOD OF RECORD.--September 1966 to current year.

EXTREMES FOR PERIOD OF RECORD.--Highest water level, $4.35 \mathrm{ft}$ below land-surface datum, October 4, 1966; lowest,

$23.59 \mathrm{ft}$ below land-surface datum, December $1,1989$.

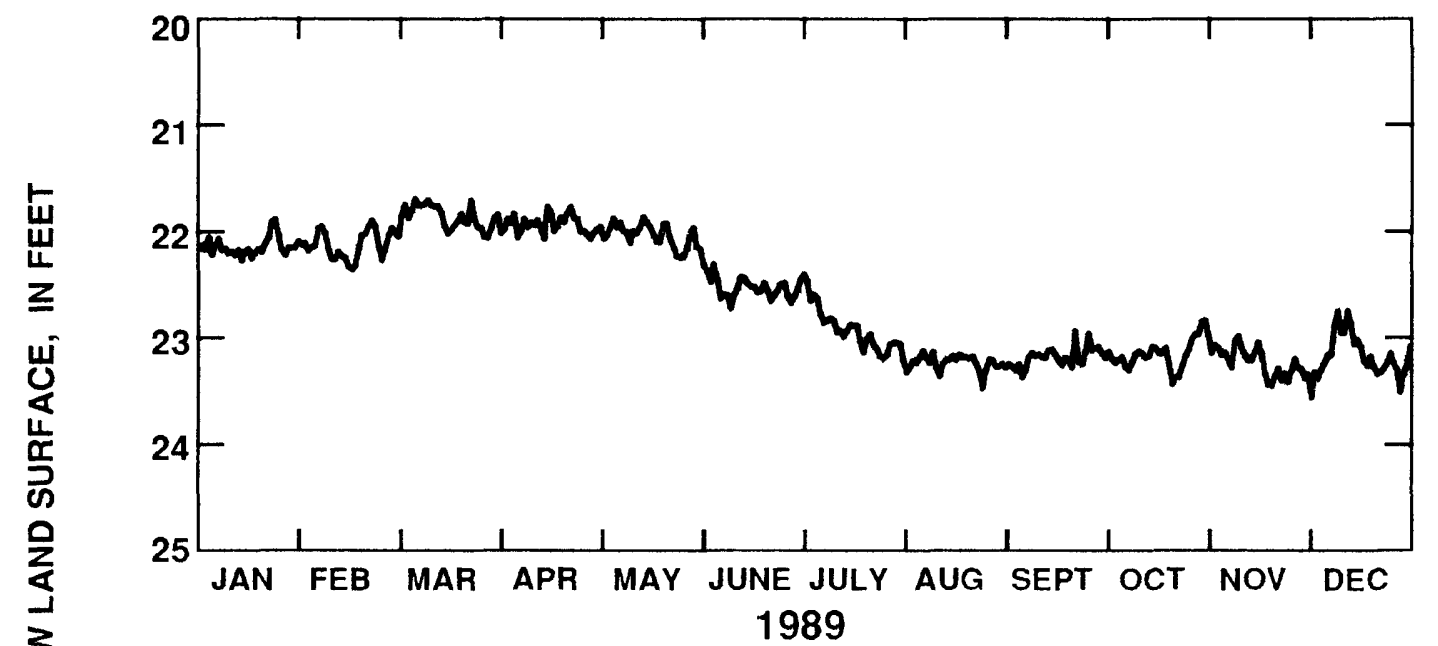

\begin{tabular}{|c|c|c|c|c|c|c|c|c|c|c|c|c|}
\hline 1989 & JAN & FEB & MAR & APR & MAY & JUN & JUL & AUG & SEP & OCT & NOV & DEC \\
\hline $\begin{array}{l}\text { MEAN } \\
\text { MAX } \\
\text { MIN }\end{array}$ & $\begin{array}{l}22.13 \\
22.26 \\
21.87\end{array}$ & $\begin{array}{l}22.11 \\
22.35 \\
21.88\end{array}$ & $\begin{array}{l}21.85 \\
22.05 \\
21.68\end{array}$ & $\begin{array}{l}21.93 \\
22.06 \\
21.75\end{array}$ & $\begin{array}{l}22.03 \\
22.24 \\
21.86\end{array}$ & $\begin{array}{l}22.53 \\
22.73 \\
22.31\end{array}$ & $\begin{array}{l}22.94 \\
23.23 \\
22.41\end{array}$ & $\begin{array}{l}23.25 \\
23.49 \\
23.14\end{array}$ & $\begin{array}{l}23.20 \\
23.39 \\
22.95\end{array}$ & $\begin{array}{l}23.18 \\
23.46 \\
22.86\end{array}$ & $\begin{array}{l}23.26 \\
23.48 \\
23.01\end{array}$ & $\begin{array}{l}23.21 \\
23.59 \\
22.77\end{array}$ \\
\hline CAL YF & 1989 & & MEAN & 22.64 & & $\mathrm{HIGH}$ & 21.68 & & LOW & 23.59 & & \\
\hline
\end{tabular}

Figure 55.--Water level in observation well 35M013, McIntosh County. 
304756081311101 Local number, 33E027.

LOCATION.--Lat 30 47'56", long 81॰31'11", Hydrologic Unit 03070203, Naval Submarine Base, Kings Bay.

Owner: U.S. Department of the Navy, Kingsbay test well 1.

AQUIFER.--Upper Floridan

WELL CHARACTERISTICS.--Drilled test well, diameter 8 in., depth 1,306 ft, cased to $555 \mathrm{ft}$, backfilled to $990 \mathrm{ft}$, open hole. DATUM.--Altitude of land-surface datum is $10.0 \mathrm{ft}$.

Measuring point: Top of flange at land-surface datum.

REMARKS.--Borehole geophysical survey conducted February 9, 1979. Water levels for periods of missing record, January 1-6,

February 9-23, March 21-27, and Octoher 27 to November 28, were estimated.

PERIOD OF RECORD.--August 1979 to current year.

EXTREMES FOR PERIOD OF RECORD.--Highest water level, $24.71 \mathrm{ft}$ above land-surface datum, March 28, 1984, and March

17, 1983; lowest, $13.90 \mathrm{ft}$ above land-surface datum, June 10-11, 1985.
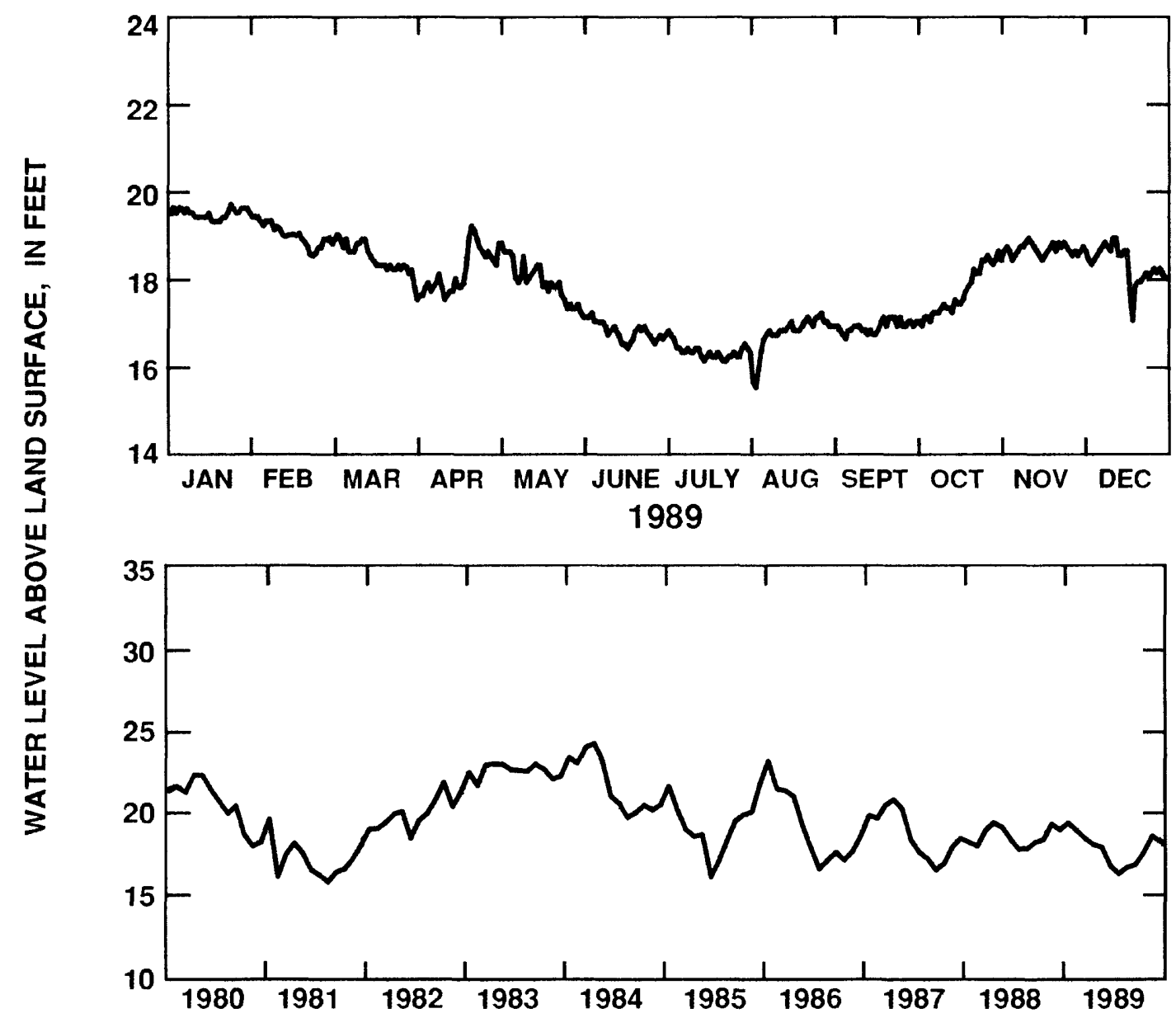

\begin{tabular}{|c|c|c|c|c|c|c|c|c|c|c|c|c|}
\hline 1989 & JAN & FEB & MAR & APR & MAY & JUN & JUL & AUG & SEP & OCT & NOV & DEC \\
\hline $\begin{array}{l}\text { MEAN } \\
\text { MAX } \\
\text { MIN }\end{array}$ & $\begin{array}{l}-19.48 \\
-19.30 \\
-19.70\end{array}$ & $\begin{array}{l}-18.99 \\
-18.52 \\
-19.40\end{array}$ & $\begin{array}{l}-18.49 \\
-17.80 \\
-19.00\end{array}$ & $\begin{array}{l}-18.12 \\
-17.50 \\
-19.20\end{array}$ & $\begin{array}{l}-17.96 \\
-17.20 \\
-18.80\end{array}$ & $\begin{array}{l}-16.79 \\
-16.40 \\
-17.20\end{array}$ & $\begin{array}{l}-16.33 \\
-16.10 \\
-16.80\end{array}$ & $\begin{array}{l}-16.73 \\
-15.50 \\
-17.20\end{array}$ & $\begin{array}{l}-16.88 \\
-16.60 \\
-17.10\end{array}$ & $\begin{array}{l}-17.64 \\
-16.90 \\
-18.60\end{array}$ & $\begin{array}{l}-18.63 \\
-18.40 \\
-18.90\end{array}$ & $\begin{array}{l}-18.30 \\
-17.00 \\
-18.90\end{array}$ \\
\hline CAL & 1989 & & ive ve & $\dot{e e}^{-17.86}$ indi & tes & $\underset{\text { water }}{\operatorname{HIG}} \underset{\text { le }}{H}$ & $\mathrm{el}^{-19.70} \mathrm{abo}$ & land & $\begin{array}{l}\text { LOW } \\
\text { surface }\end{array}$ & ]$^{-15.50}$ & & \\
\hline
\end{tabular}

Figure 56.--Water level in observation well 33E027, Camden County. 
304942082213801 Local number, $27 \mathrm{E} 004$.

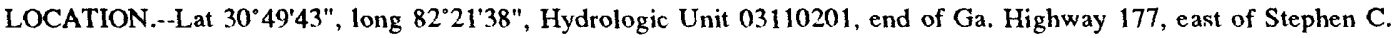
Foster State Park.

Owner: U.S. Geological Survey test well OK-9.

AQUIFER.--Upper Floridan

WELL CHARACTERISTICS.--Drilled observation well, diameter 4 in., depth $700 \mathrm{ft}$, cased to $498 \mathrm{ft}$, open hole.

DATUM.--Altitude of land-surface datum is $116 \mathrm{ft}$.

Measuring point: Top of recorder shelf, $4.3 \mathrm{ft}$ above land-surface datum.

REMARKS.--Well drilled in May, 1978 to replace U.S. Geological Survey test well OK-8 (27E002).

PERIOD OF RECORD.--June 14, 1978 to January 26, 1979: January 1, 1980 to current year.

EXTREMES FOR PERIOD OF RECORD.--Highest water level, $62.30 \mathrm{ft}$ below land-surface datum, May 9, 1984: lowest,

$71.87 \mathrm{ft}$ below land-surface datum, June 18, 1989 .

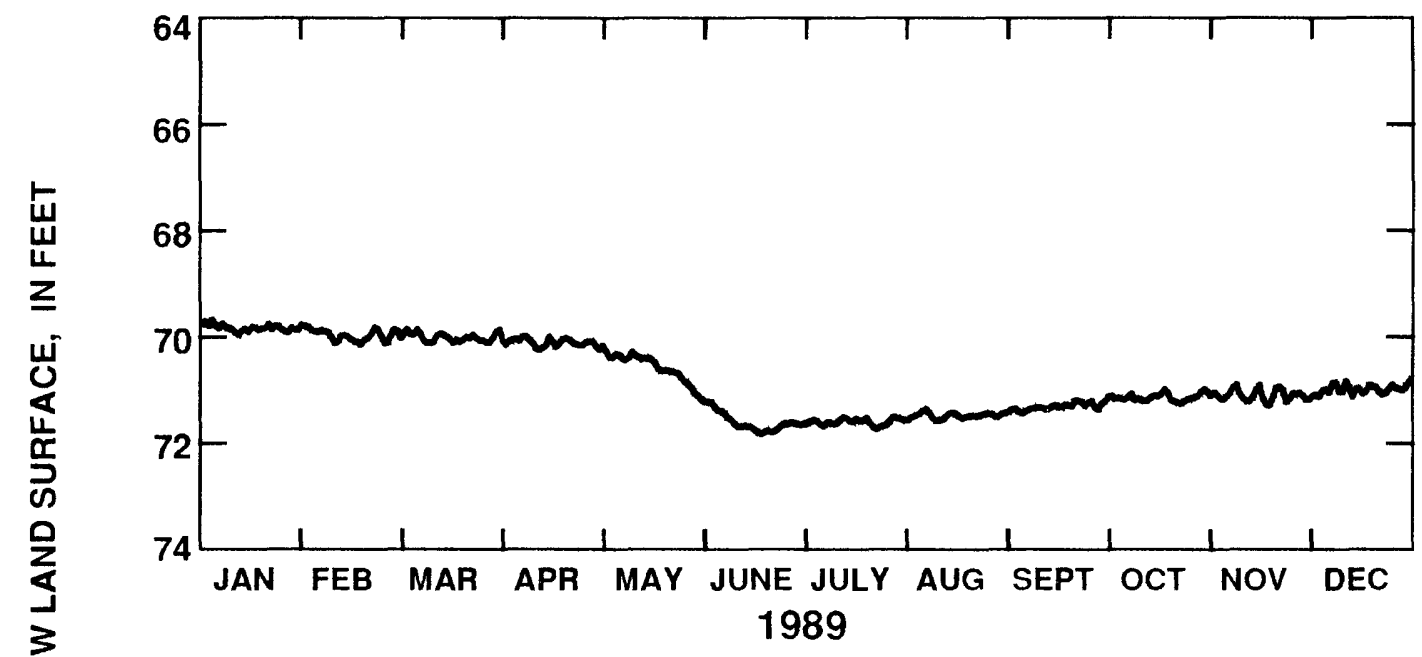

\begin{tabular}{|c|c|c|c|c|c|c|c|c|c|c|c|c|}
\hline 1989 & JAN & FEB & MAR & APR & MAY & JUN & JUL & AUG & SEP & OCT & NOV & DEC \\
\hline $\begin{array}{l}\text { MEAN } \\
\text { MAX } \\
\text { MIN }\end{array}$ & $\begin{array}{l}69.87 \\
70.00 \\
69.72\end{array}$ & $\begin{array}{l}70.02 \\
70.18 \\
69.85\end{array}$ & $\begin{array}{l}70.05 \\
70.16 \\
69.90\end{array}$ & $\begin{array}{l}70.15 \\
70.29 \\
70.04\end{array}$ & $\begin{array}{l}70.62 \\
71.23 \\
70.22\end{array}$ & $\begin{array}{l}71.65 \\
71.87 \\
71.27\end{array}$ & $\begin{array}{l}71.64 \\
71.78 \\
71.56\end{array}$ & $\begin{array}{l}71.53 \\
71.63 \\
71.41\end{array}$ & $\begin{array}{l}71.36 \\
71.48 \\
71.25\end{array}$ & $\begin{array}{l}71.19 \\
71.30 \\
71.04\end{array}$ & $\begin{array}{l}71.15 \\
71.35 \\
70.96\end{array}$ & $\begin{array}{l}71.05 \\
71.23 \\
70.89\end{array}$ \\
\hline CAL YF & 1989 & & MEAN & 70.86 & & $\mathrm{HIGH}$ & 69.72 & & LOW & 71.87 & & \\
\hline
\end{tabular}

Figure 57.--Water level in observation well 27E004, Charlton County. 
311007081301701 Local number, 33H127.

LOCATION.--Lat $31^{\circ} 10^{\prime} 06^{\prime \prime}$, long $81^{\circ} 30^{\prime} 16^{\prime \prime}$, Hydrologic Unit 03070203 , in south corner of Greenwood Cemetery, in Brunswick.

Owner: U.S. Geological Survey test well 3.

AQUIFER.--Upper Floridan aquifer; lower water-bearing zone.

WELL CHARACTERISTICS.--Drilled observation well, diameter 4 in., depth 1,002 ft, cased to $823 \mathrm{ft}$, open hole.

DATUM.--Altitude of land-surface datum is $6.2 \mathrm{ft}$.

Measuring point: Top of recorder shelf, $8.00 \mathrm{ft}$ above land-surface datum.

REMARKS.--Water levels for periods of missing record, May 20 to June 10, and June 27 to July 13, were estimated.

Well pumped and sampled for analysis of chloride concentration semi-annually.

PERIOD OF RECORD.--August 1962 to current year.

EXTREMES FOR PERIOD OF RECORD.--Highest water level, $14.00 \mathrm{ft}$ above land-surface datum, October 9,$1962 ;$ lowest,

$11.19 \mathrm{ft}$ below land-surface datum, July 14, 1977.

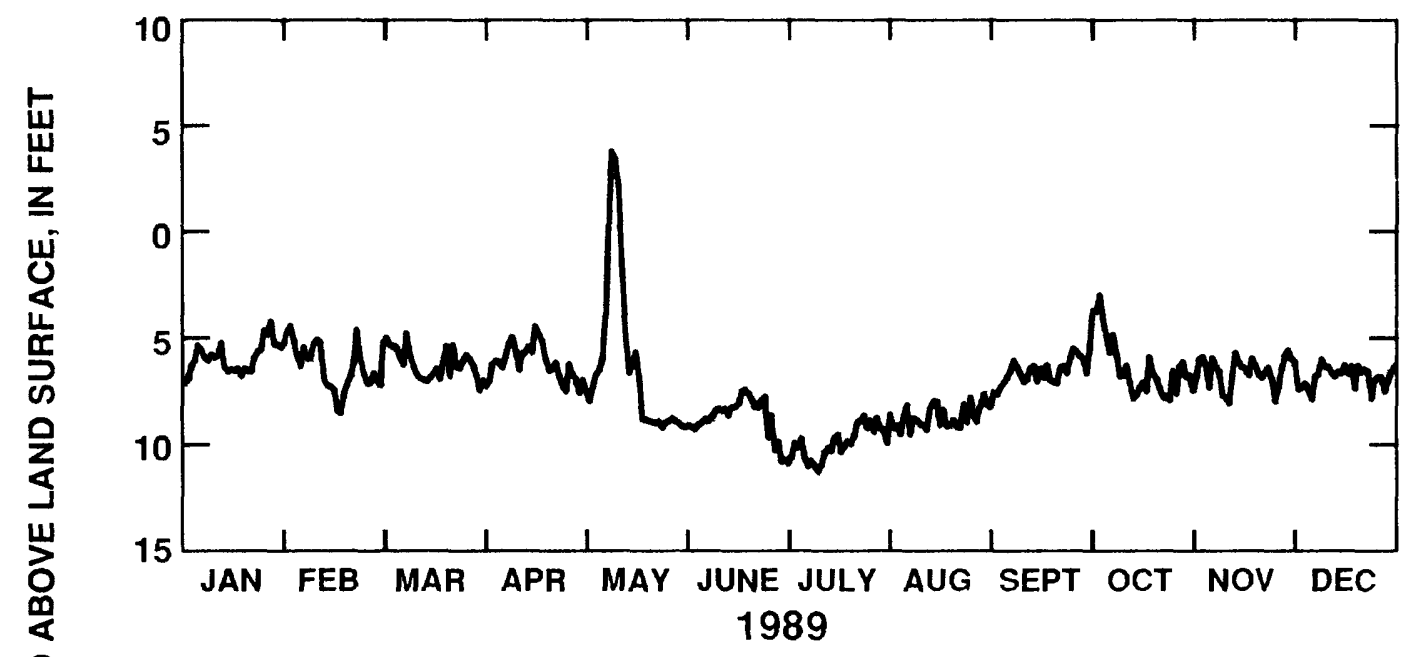

\begin{tabular}{|c|c|c|c|c|c|c|c|c|c|c|c|c|}
\hline 1989 & JAN & FEB & MAR & APR & MAY & JUN & JUL & AUG & SEP & OCT & NOV & DEC \\
\hline $\begin{array}{l}\text { MEAN } \\
\text { MAX } \\
M I N\end{array}$ & $\begin{array}{l}5.86 \\
6.96 \\
4.20\end{array}$ & $\begin{array}{l}6.33 \\
8.51 \\
4.42\end{array}$ & $\begin{array}{l}6.18 \\
7.44 \\
4.74\end{array}$ & $\begin{array}{l}6.17 \\
7.57 \\
4.46\end{array}$ & $\begin{array}{r}6.18 \\
9.20 \\
-3.88\end{array}$ & $\begin{array}{r}8.68 \\
10.81 \\
7.45\end{array}$ & $\begin{array}{r}9.99 \\
11.18 \\
8.68\end{array}$ & $\begin{array}{l}8.80 \\
9.97 \\
7.71\end{array}$ & $\begin{array}{l}6.70 \\
8.28 \\
5.56\end{array}$ & $\begin{array}{l}6.37 \\
7.98 \\
3.03\end{array}$ & $\begin{array}{l}6.72 \\
8.14 \\
5.66\end{array}$ & $\begin{array}{l}6.87 \\
7.96 \\
6.06\end{array}$ \\
\hline CAL YR & 1989 & & $\begin{array}{l}\text { MEAN } \\
\text { Ve Va }\end{array}$ & $\begin{array}{l}7.08 \\
\text { ind }\end{array}$ & es & $\begin{array}{l}\text { HIGH } \\
\text { ter le }\end{array}$ & $\begin{array}{r}-3.88 \\
\text { abo }\end{array}$ & land & $\begin{array}{l}\text { LOW } \\
\text { surface] }\end{array}$ & 11.18 & & \\
\hline
\end{tabular}

Figure 58.--Water level in observation well $33 \mathrm{H} 127$, Glynn County. 
311007081301702 Local number, 33H133.

LOCATION.--Lat $31^{\circ} 10^{\prime} 08^{\prime \prime}$, long $81^{\circ} 30^{\prime} 16^{\prime \prime}$, Hydrologic Unit 03070203, in south corner of Greenwood Cemetery, in

Brunswick.

Owner: U.S. Geological Survey test well 6.

AQUIFER.--Upper Floridan aquifer; upper water-bearing zone.

WELL CHARACTERISTICS.--Drilled observation well, diameter 4 in., depth $790 \mathrm{ft}$, cased to $520 \mathrm{ft}$, open hole.

DATUM.--Altitude of land-surface datum is $6.7 \mathrm{ft}$.

Measuring point: Top of recorder shelf, $5.1 \mathrm{ft}$ above land-surface datum

REMARKS.--Well pumped and sampled for analysis of chloride concentration semi-annually. Borehole geophysical survey conducted

September 26, 1977.

PERIOD OF RECORD.--January 1963 to current year.

EXTREMES FOR PERIOD OF RECORD.--Highest water level, $9.07 \mathrm{ft}$ above land-surface datum, December 26, 1965: lowest,

$21.87 \mathrm{ft}$ below land-surface datum, July 22, 1977.
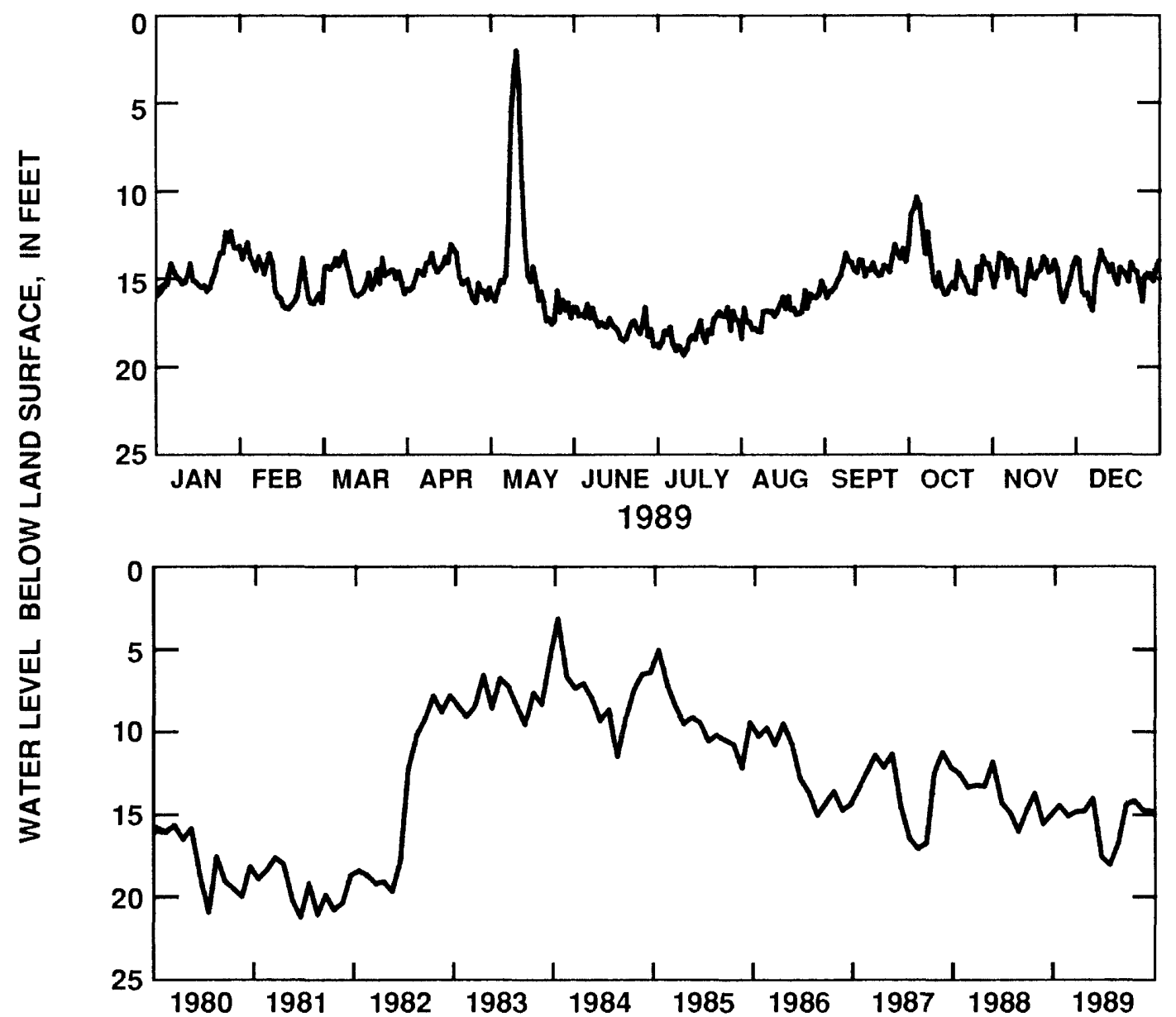

\begin{tabular}{|c|c|c|c|c|c|c|c|c|c|c|c|c|}
\hline 1989 & JAN & FEB & MAR & APR & MAY & JUN & JUL & AUG & SEP & OCT & NOV & DEC \\
\hline $\begin{array}{l}\text { MEAN } \\
\text { MAX } \\
\text { MIN }\end{array}$ & $\begin{array}{l}14.46 \\
15.71 \\
12.24\end{array}$ & $\begin{array}{l}15.15 \\
16.70 \\
12.89\end{array}$ & $\begin{array}{l}14.86 \\
16.34 \\
13.40\end{array}$ & $\begin{array}{l}14.81 \\
16.38 \\
12.99\end{array}$ & $\begin{array}{r}14.05 \\
17.59 \\
1.87\end{array}$ & $\begin{array}{l}17.58 \\
18.83 \\
16.47\end{array}$ & $\begin{array}{l}18.07 \\
19.35 \\
16.66\end{array}$ & $\begin{array}{l}16.79 \\
18.43 \\
15.17\end{array}$ & $\begin{array}{l}14.45 \\
16.09 \\
13.07\end{array}$ & $\begin{array}{l}14.19 \\
15.92 \\
10.35\end{array}$ & $\begin{array}{l}14.77 \\
16.38 \\
13.56\end{array}$ & $\begin{array}{l}14.89 \\
16.87 \\
13.44\end{array}$ \\
\hline CAL Y & 1989 & & MEAN & 15.34 & & HIGH & 1.87 & & LOW & 19.35 & & \\
\hline
\end{tabular}

Figure 59.--Water level in observation well $33 \mathrm{H} 133$, Glynn County. 


\section{Lower Floridan aquifer}

\section{Brunswick area}

The water level in the Lower Floridan aquifer is monitored in five wells in the Brunswick area, two of which are included in this report (figs. 60-62). The water level in wells tapping the Lower Floridan aquifer in this area primarily is influenced by pumping from the Floridan aquifer system. This response is shown on the hydrographs for wells 34H391 (fig. 61) and 33J044 (fig. 62). Partial industrial shutdowns in pumping from the Floridan aquifer system during May resulted in sharp rises in water level in the two wells. The two wells also show a downward trend in water levels since 1983 similar to that observed in the Upper Floridan aquifer. The mean water level in well 34H391 was $1.7 \mathrm{ft}$ lower in 1989 than in 1988, and in well 33J044 the mean water level was $1.4 \mathrm{ft}$ lower.

\section{Claiborne Aquifer}

The water level in the Claiborne aquifer is monitored in 22 wells, records from 11 are included in this report (figs. 63-74). Water levels in the aquifer are affected primarily by precipitation and by local and regional pumping. During 1985, the aquifer supplied $62 \mathrm{Mgal} / \mathrm{d}$, primarily for industrial and agricultural uses (Pierce and Kundell, 1990, p. 219). The water level generally is highest during winter and spring rainy seasons, and lowest in the fall following the summer irrigation season.

November 1989 water-level measurements from 88 wells tapping the Claiborne aquifer were used to construct a water-level map (fig. 63). This map indicates that a cone of depression is centered at Albany. The configuration of the water-level surface showed little change during 1988-89. However, a cone of depression at Cordele, Crisp County, formed as a result of localized pumping during 1989.

During 1989, the water levels in seven wells (11L001, 12L019, 06K010, 09G001, 09M009, 14P015, and 15R007, figs 64-70) continued to recover from the effects of the 1986 drought. In these seven wells, the mean water level was from 0.1 to $2.7 \mathrm{ft}$ higher in 1989 than 1988, which is attributed to decreased regional pumping and above-normal precipitation. (See precipitation graph for Albany, figure 8.) In four wells (13L011, 11K002, $11 \mathrm{P} 015$, and 13M005, figs. 71-74), the mean water level was from 0.2 to $0.9 \mathrm{ft}$ lower in 1989 than in 1988 . The lower water levels in the four wells are attributed to localized decreased precipitation and increased pumping. Although water levels in the four wells were lower in 1989 than 1988, the overall trend during 1986-89 has been upward.

\section{Clayton Aquifer}

Water-level fluctuations and trends in the Clayton aquifer are monitored in 12 wells, records from eight are included in this report (figs. 75-83). Water levels in the aquifer are affected primarily by seasonal changes in local and regional pumping. During 1985, the aquifer supplied more than $33 \mathrm{Mgal} / \mathrm{d}$, primarily for agricultural use (Pierce and Kundell, 1990, p. 219). Pumping from the Clayton aquifer has resulted in the development of a cone of depression centered at Albany (fig. 75).

During November 1989, water levels were measured in 74 wells tapping the Clayton aquifer. From these measurements, a water-level map was constructed showing the configuration of the water-level surface (fig. 75). The areal extent of the cone of depression at Albany was smaller in November 1989 than during 1988, which may be the result of a reduction in pumping in that area. In addition, the mean water levels in seven of the wells (wells 14P014, 07N001, 09M007, 09N001, 11L002, 13L002, and 06K009, figs. 76-82) were from 1.1 to $10.8 \mathrm{ft}$ higher in 1989 than in 1988.

At well 11K005 (fig. 83) southwest of Albany, the mean water level was $1.4 \mathrm{ft}$ lower in 1989 than in 1988, and a record low water level was measured in February 1989. The water level continued to decline in this area. 


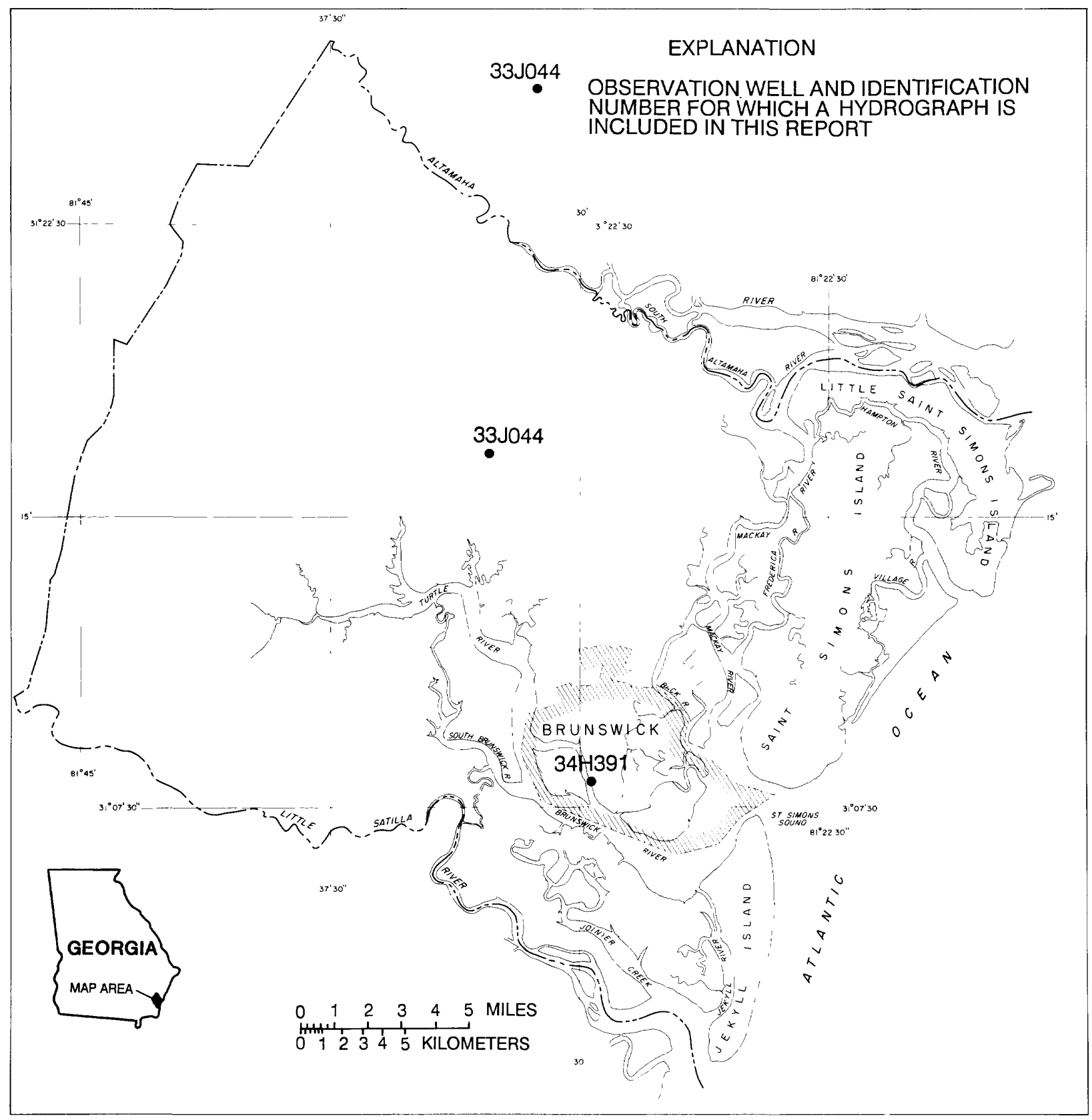

Figure 60.--Locations of observation wells completed in the Lower Floridan aquifer. 
310818081294201 Local number, 34H391.

LOCATION.--Lat 31 $08^{\prime} 18^{\prime \prime}$, long $81^{\circ} 29^{\prime} 42^{\prime \prime}$, Hydrologic Unit 03070203, located near intersection of Albermarle Street

and Bay Street, in Brunswick.

Owner: U.S. Geological Survey test well 16.

AQUIFER.--Lower Floridan

WELL CHARACTERISTICS.--Drilled observation well, diameter 6 in., depth 1,150 ft, cased to 1,070 ft, open hole.

DATUM.--Altitude of land-surface datum is $7.13 \mathrm{ft}$.

Measuring point: Top of recorder shelf, $12.5 \mathrm{ft}$ above land-surface datum.

REMARKS.--Well pumped and sampled for analysis of chloride concentration semi-annually. Water levels for periods of missing record,

January 1-4, February 13-19, February 24 to March 1, May 15-18, June 5-30, and October 2-5, were estimated.

PERIOD OF RECORD.--August 1975 to current year.

EXTREMES FOR PERIOD OF RECORD.--Highest water level, $11.65 \mathrm{ft}$ above land-surface datum, Octoher 13-14, 1985:

lowest, $2.96 \mathrm{ft}$ below land-surface datum, July 27, 1977.
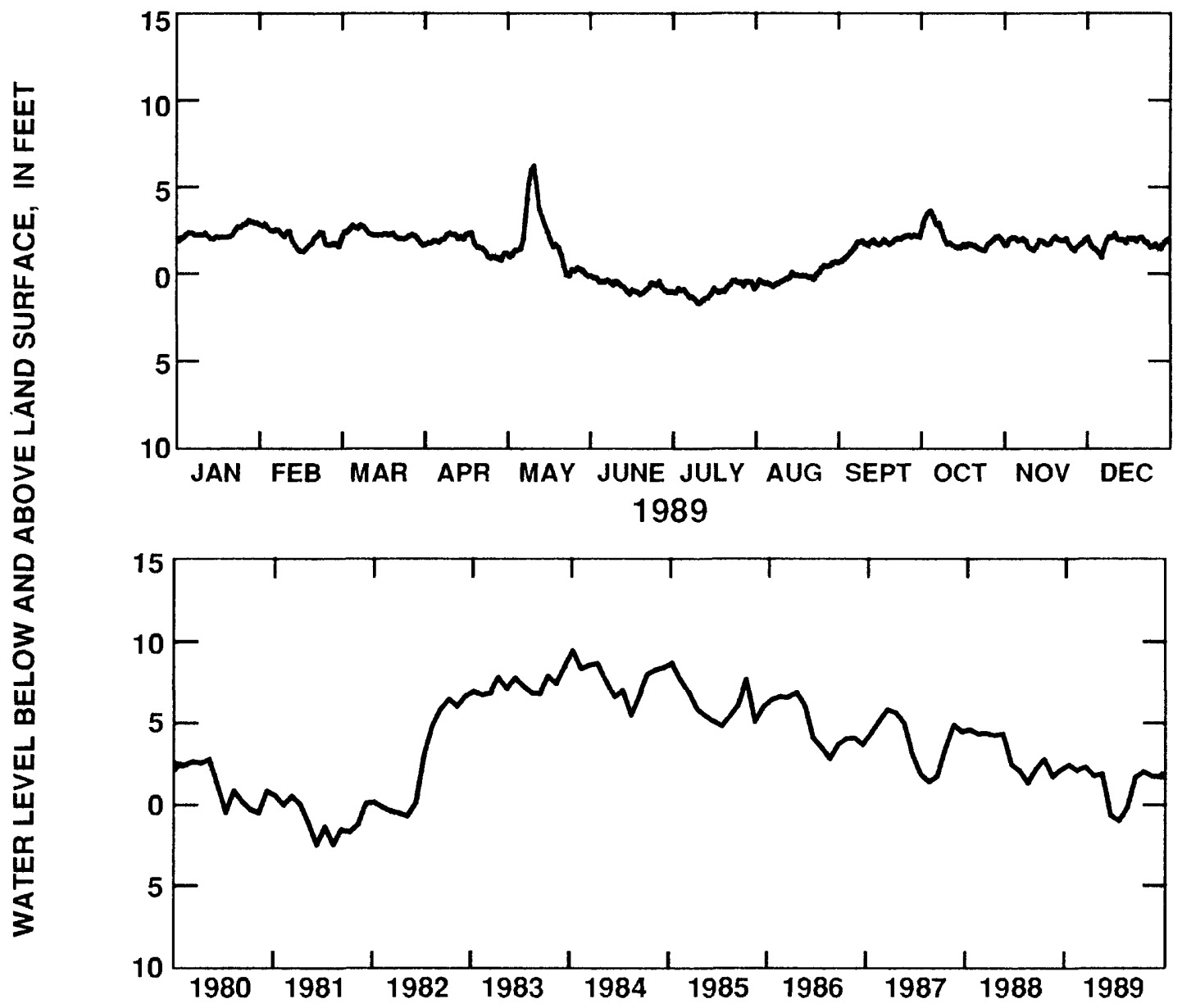

\begin{tabular}{|c|c|c|c|c|c|c|c|c|c|c|c|c|}
\hline 1989 & JAN & FEB & MAR & APR & MAY & JUN & JUL & AUG & SEP & OCT & NOV & DEC \\
\hline $\begin{array}{l}\text { MEAN } \\
\text { MAX } \\
\text { MIN }\end{array}$ & $\begin{array}{l}-2.47 \\
-2.03 \\
-3.17\end{array}$ & $\begin{array}{l}-2.12 \\
-1.34 \\
-2.95\end{array}$ & $\begin{array}{l}-2.34 \\
-1.65 \\
-2.89\end{array}$ & $\begin{array}{r}-1.78 \\
-.82 \\
-2.42\end{array}$ & $\begin{array}{r}-1.92 \\
.10 \\
-6.33\end{array}$ & $\begin{array}{r}.65 \\
1.17 \\
.10\end{array}$ & $\begin{array}{r}.97 \\
1.68 \\
.40\end{array}$ & $\begin{array}{r}.18 \\
.88 \\
-.68\end{array}$ & $\begin{array}{r}-1.71 \\
-.63 \\
-2.23\end{array}$ & $\begin{array}{l}-2.06 \\
-1.32 \\
-3.65\end{array}$ & $\begin{array}{l}-1.76 \\
-1.30 \\
-2.12\end{array}$ & $\begin{array}{r}-1.75 \\
-.89 \\
-2.29\end{array}$ \\
\hline$A L$ & 1907 & [Nege & $\begin{array}{l}\text { MEAN } \\
\text { ve va }\end{array}$ & $\begin{array}{l}-1.34 \\
\text { ind }\end{array}$ & tes & $\underset{\text { ter }}{\mathrm{HI}} \underset{\mathrm{le}}{\mathrm{H}}$ & $\begin{array}{l}-6.33 \\
\text { abol }\end{array}$ & lan & $\begin{array}{l}\text { LOW } \\
\text { surface }\end{array}$ & 1.68 & & \\
\hline
\end{tabular}

Figure 61.--Water level in observation well $34 \mathrm{H} 391$, Glynn County. 
311633081324001 Local number, $33 \mathrm{~J} 044$.

LOCATION.--Lat $31^{\circ} 16^{\prime} 33^{\prime \prime}$, long $81^{\circ} 32^{\prime} 40^{\prime \prime}$, Hydrologic Unit 03070203, 1.2 mi east of Sterling, off Ga. Highway 99

at the Brunswick Pulp and Paper Company, Sterling Wood Products Division.

Owner: Brunswick Pulp and Paper Co., USGS test well 27.

AQUIFER.--Lower Floridan

WELL CHARACTERISTICS.--Drilled unused oil-test well converted to observation well, diameter 9 in., depth 2,260

$\mathrm{ft}$, cased to $1,079 \mathrm{ft}$, open hole.

DATUM.--Altitude of land-surface datum is $20 \mathrm{ft}$.

Measuring point: Top of recorder shelf, $9.5 \mathrm{ft}$ above land-surface datum.

REMARKS.--This is the Sterling oil-test well.

PERIOD OF RECORD.--May 1979 to current year.

EXTREMES FOR PERIOD OF RECORD.--Highest water level, $3.09 \mathrm{ft}$ above land-surface datum, October 13, 1985; lowest,

$6.63 \mathrm{ft}$ below land-surface datum, July 12, 1989.
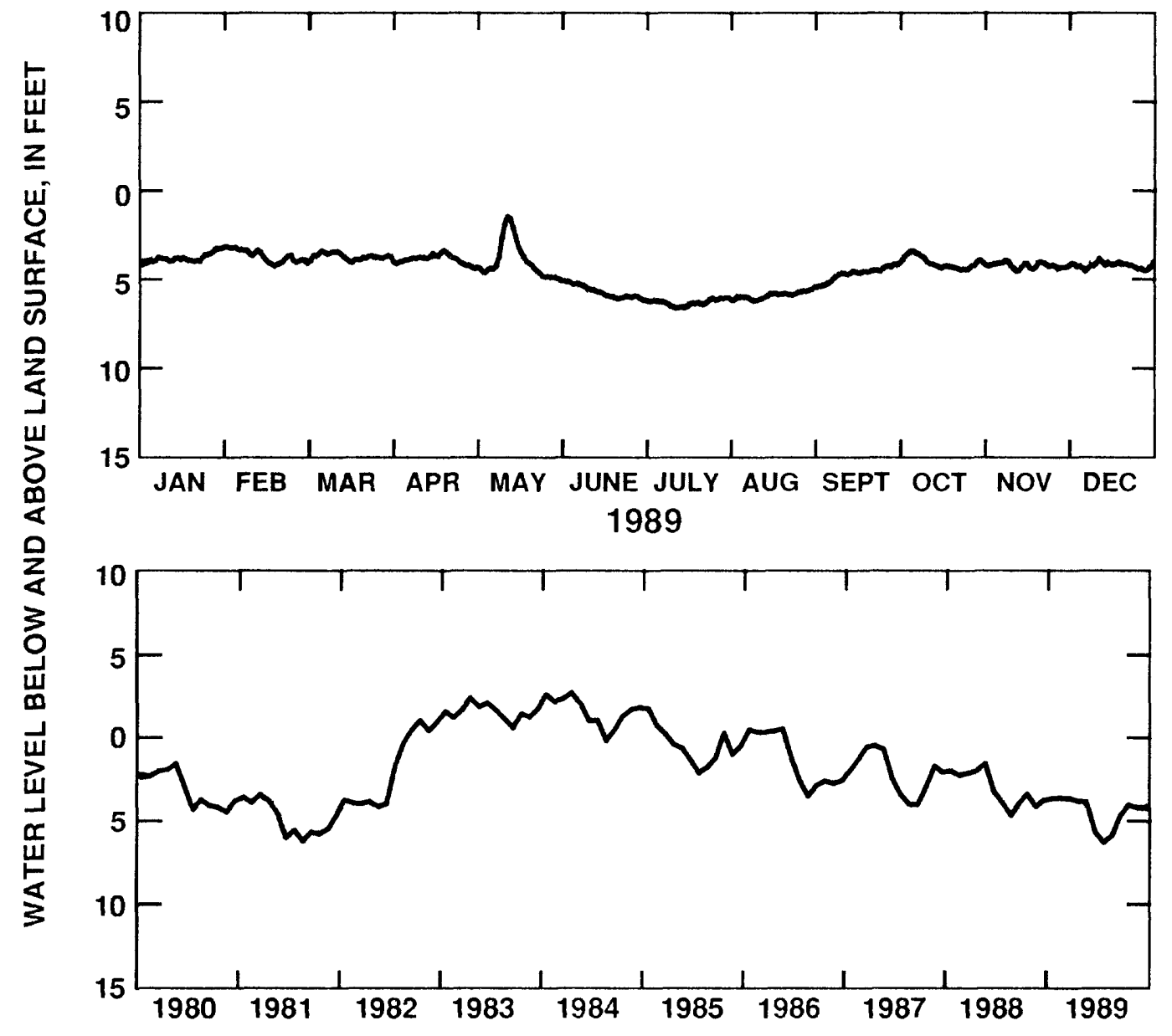

\begin{tabular}{|c|c|c|c|c|c|c|c|c|c|c|c|c|}
\hline 1989 & JAN & FEB & MAR & APR & MAY & JUN & JUL & AUG & SEP & OCT & NOV & DEC \\
\hline MEAN & 3.68 & 3.66 & 3.67 & 3.83 & 3.90 & 5.70 & 6.33 & 5.92 & 4.70 & 4.07 & 4.25 & 4.26 \\
\hline MAX & 3.99 & 4.21 & 4.05 & 4.37 & 4.99 & 6.17 & 6.63 & 6.24 & 5.43 & 4.48 & 4.57 & 4.59 \\
\hline MIN & 3.10 & 3.14 & 3.35 & 3.33 & 1.41 & 5.08 & 6.06 & 5.46 & 4.16 & 3.41 & 3.97 & 3.87 \\
\hline SAL Y & 1989 & & MEAN & 4.50 & & $\mathrm{HIGH}$ & 1.41 & & LOW & 6.63 & & \\
\hline
\end{tabular}

Figure 62.--Water level in observation well 33J044, Glynn County. 


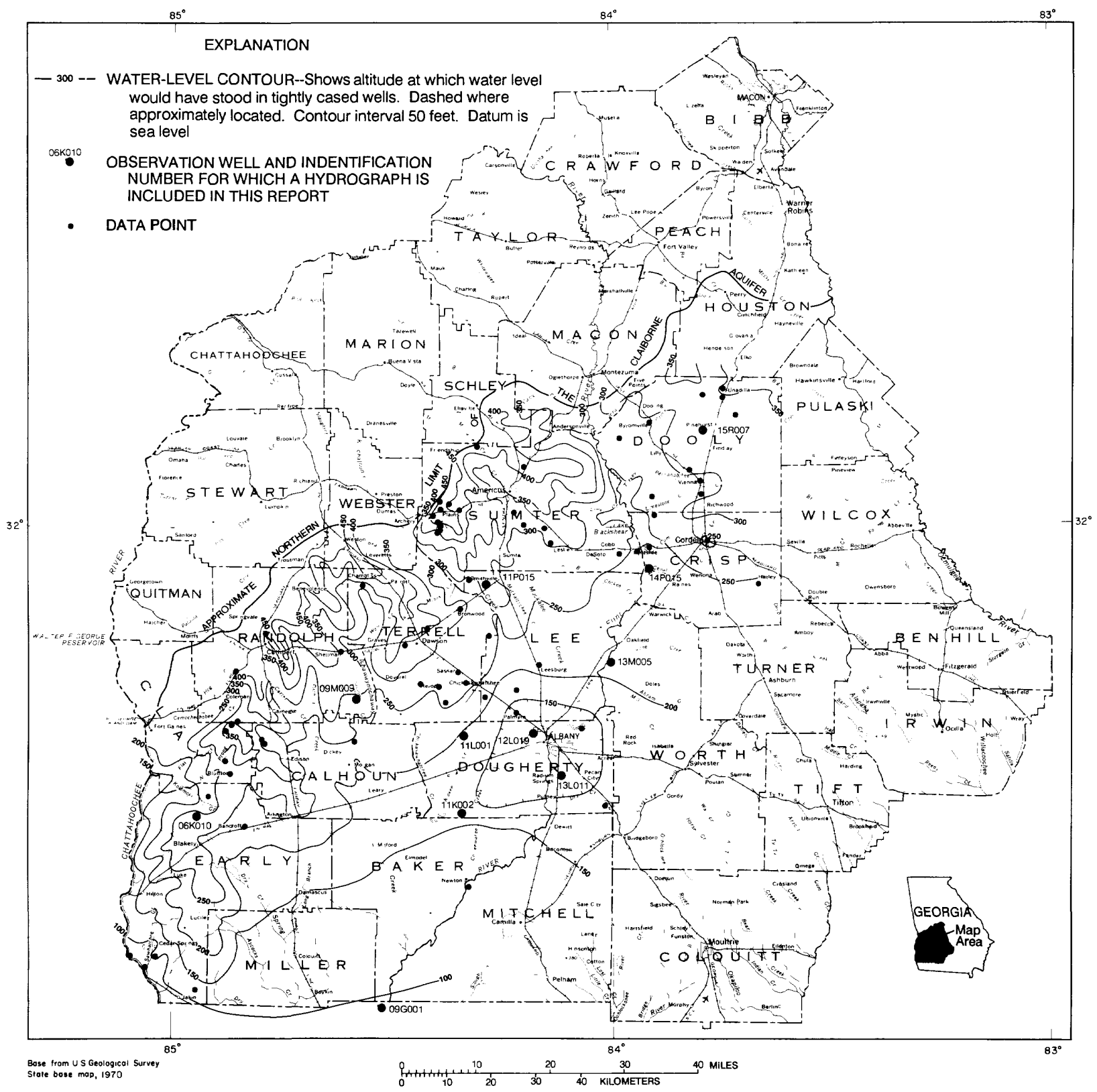

Figure 63.--Water levels and locations of observation wells in the Claiborne aquifer, November 1989. 
313530084203202 Local number, $11 \mathrm{L001.}$

LOCATION.--Lat $31^{\circ} 35^{\prime} 30^{\prime \prime}$, long $84^{\circ} 20^{\prime} 34^{\prime \prime}$, Hydrologic Unit 03130008, Tallahassee Plantation, 1.3 mi north of Ga.

Highway 234, $10.4 \mathrm{mi}$ west of Albany.

Owner: U.S. Geological Survey test well 4.

AQUIFER.--Claiborne.

WELL CHARACTERISTICS.--Drilled observation well, diameter 4 in.. depth $251 \mathrm{ft}$, cased to $233 \mathrm{ft}$, screen to $251 \mathrm{ft}$.

DATUM.--Altitude of land-surface datum is $220 \mathrm{ft}$.

Measuring point: Top of recorder shelf, $3.0 \mathrm{ft}$ above land-surface datum.

REMARKS.--Well pumped and redeveloped August 14, 1988.

PERIOD OF RECORD.--March 1978 to current year.

EXTREMES FOR PERIOD OF RECORD.--Highest water level, $12.11 \mathrm{ft}$ below land-surface datum, June 5-6, 1978: lowest,

$34.75 \mathrm{ft}$ below land-surface datum, October 19-20, 1986.

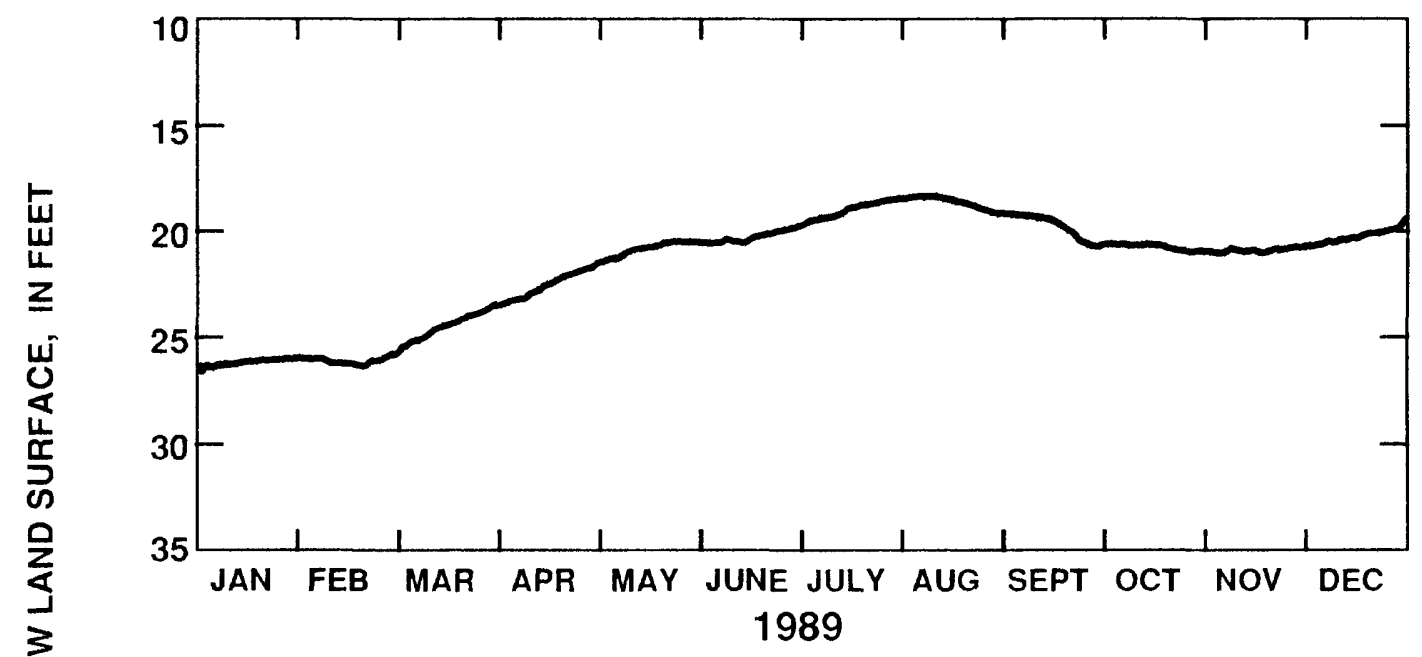

\begin{tabular}{|c|c|c|c|c|c|c|c|c|c|c|c|c|}
\hline 1989 & JAN & FEB & MAR & APR & MAY & JUN & JUL & AUG & SEP & OCT & NOV & DEC \\
\hline $\begin{array}{l}\text { MEAN } \\
\text { MAX } \\
\text { MIN }\end{array}$ & $\begin{array}{l}26.17 \\
26.43 \\
25.98\end{array}$ & $\begin{array}{l}26.11 \\
26.34 \\
25.79\end{array}$ & $\begin{array}{l}24.52 \\
25.79 \\
23\end{array}$ & $\begin{array}{l}22.55 \\
23.46 \\
21\end{array}$ & $\begin{array}{l}20.81 \\
21.47\end{array}$ & $\begin{array}{l}20.24 \\
20.52\end{array}$ & $\begin{array}{l}18.99 \\
19.70\end{array}$ & $\begin{array}{l}18.57 \\
19.13\end{array}$ & $\begin{array}{l}19.69 \\
20.69 \\
10\end{array}$ & $\begin{array}{l}20.70 \\
20.94 \\
20\end{array}$ & $\begin{array}{l}20.87 \\
20.99 \\
2071\end{array}$ & $\begin{array}{l}20.26 \\
20.71\end{array}$ \\
\hline CAL YF & 1989 & & MEAN & 21.60 & & HIGH & 18.29 & & LOW & 26.43 & & \\
\hline
\end{tabular}

Figure 64.--Water level in observation well 11L001, Dougherty County. 
313534084103001 Local number, $12 \mathrm{LO} 19$.

LOCATION.--Lat $31^{\circ} 35^{\prime} 36^{\prime \prime}$, long $84^{\circ} 10^{\prime} 30^{\prime \prime}$, Hydrologic Unit 03130008 , located in southwest corner of park, $500 \mathrm{ft}$ east of intersection of Slappey Drive and Fifth Avenue.

Owner: U.S. Geological Survey test well 5.

AQUIFER.--Claibome.

WELL CHARACTERISTICS.--Drilled observation well, diameter 4 in., depth $257 \mathrm{ft}$, cased to $241 \mathrm{ft}$, screen to $257 \mathrm{ft}$. DATUM.--Altitude of land-surface datum is $198 \mathrm{ft}$.

Measuring point: Top of recorder shelf, $3.0 \mathrm{ft}$ above land-surface datum.

REMARKS.--Well pumped and redeveloped August 15, 1988. Water levels for period of missing record, May 26 to

June 21, were estimated.

PERIOD OF RECORD.--March 1978 to current year.

EXTREMES FOR PERIOD OF RECORD.--Highest water level, $68.63 \mathrm{ft}$ below land-surface datum, December 31 , 1989 ; lowest, $99.53 \mathrm{ft}$ below land-surface datum, August 1-2, 1978 .
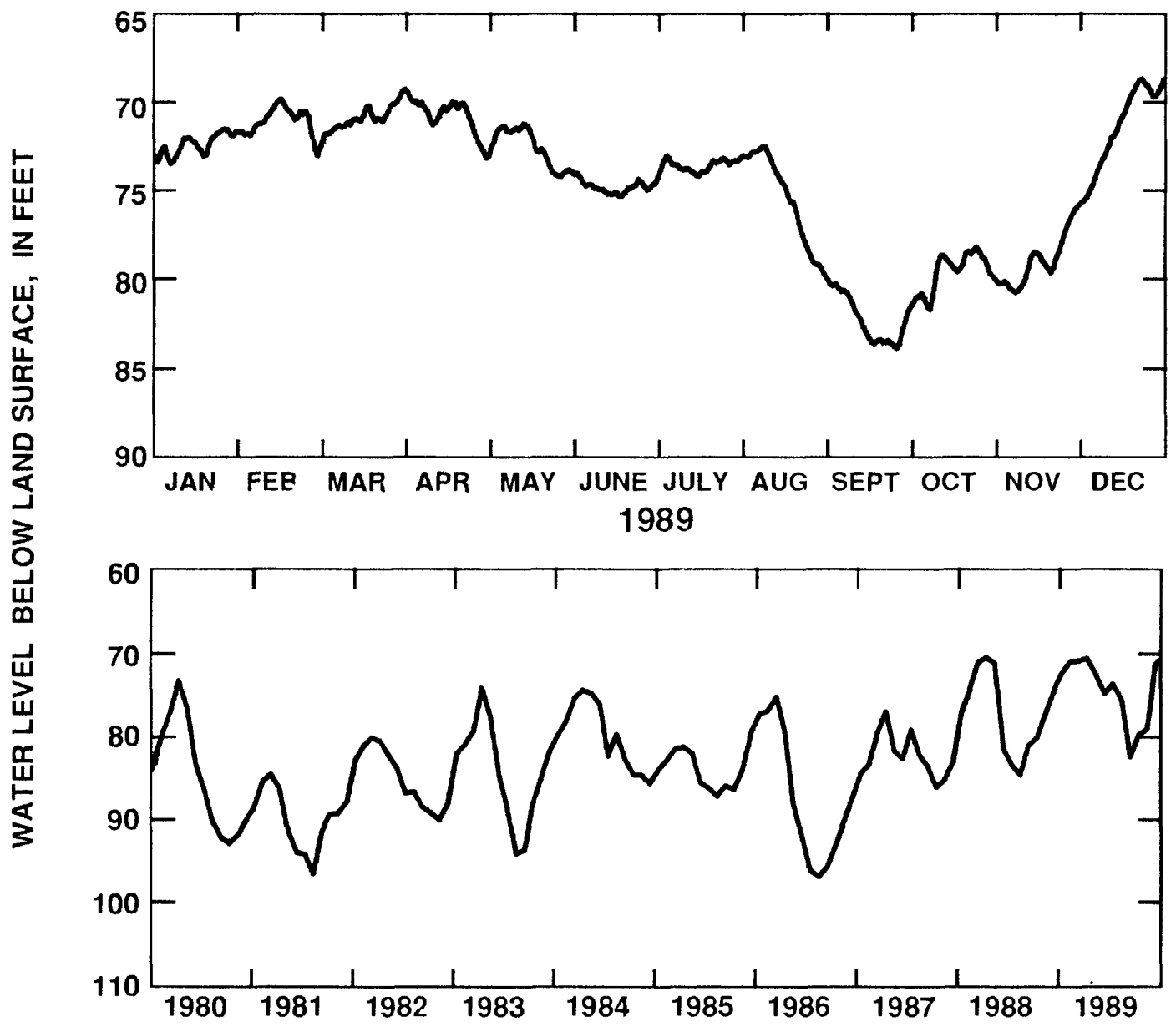

\begin{tabular}{|c|c|c|c|c|c|c|c|c|c|c|c|c|}
\hline 1989 & JAN & FEB & MAR & APR & MAY & JUN & JUL & AUG & SEP & OCT & NOV & DEC \\
\hline $\begin{array}{l}\text { MEAN } \\
\text { MAX } \\
\text { MIN }\end{array}$ & $\begin{array}{l}72.21 \\
73.33 \\
71.36\end{array}$ & $\begin{array}{l}70.85 \\
72.84 \\
69.62\end{array}$ & $\begin{array}{l}70.80 \\
72.43 \\
69.23\end{array}$ & $\begin{array}{l}70.52 \\
73.04 \\
69.09\end{array}$ & $\begin{array}{l}72.45 \\
74.12 \\
71.10\end{array}$ & $\begin{array}{l}74.75 \\
75.25 \\
73.99\end{array}$ & $\begin{array}{l}73.54 \\
74.20 \\
72.96\end{array}$ & $\begin{array}{l}75.51 \\
80.07 \\
72.45\end{array}$ & $\begin{array}{l}82.39 \\
83.97 \\
80.33\end{array}$ & $\begin{array}{l}79.68 \\
81.78 \\
78.28\end{array}$ & $\begin{array}{l}79.03 \\
80.83 \\
75.89\end{array}$ & $\begin{array}{l}71.39 \\
75.73 \\
68.63\end{array}$ \\
\hline CAL YF & 1989 & & MEAN & 74.43 & & $\mathrm{HIGH}$ & 68.63 & & LOW & 83.97 & & \\
\hline
\end{tabular}

Figure 65.--Water level in observation well 12L019, Dougherty County. 
312827084551503 Local number, 06K010.

LOCATION.--Lat $31^{\circ} 28^{\prime} 24^{\prime \prime}$, long 84'55'09", Hydrologic Unit 03130004, easternmost of two recorder wells, 300 yds north of the pool at Kolomoki Mounds State Park, 4.2 mi north of the city limits of Blakely, on Kolomoki Road.

Owner: Georgia Geologic Survey, Kolomoki Mounds State Park test well 3.

AQUIFER.--Claiborne.

WELL CHARACTERISTICS.--Drilled observation well, diameter 4 in., depth $140 \mathrm{ft}$, cased to $120 \mathrm{ft}$, screen to $140 \mathrm{ft}$.

DATUM.--Altitude of land-surface datum is $310 \mathrm{ft}$.

Measuring point: Top of recorder shelf, $3.56 \mathrm{ft}$ above land-surface datum.

REMARKS.--Well pumped and redeveloped August 8, 1989.

PERIOD OF RECORD.--August 31, 1984 to current year.

EXTREMES FOR PERIOD OF RECORD.--Highest water level, $73.72 \mathrm{ft}$ below land-surface datum, August 31 , 1984: lowest,

$77.35 \mathrm{ft}$ below land-surface datum, November $14,1986$.
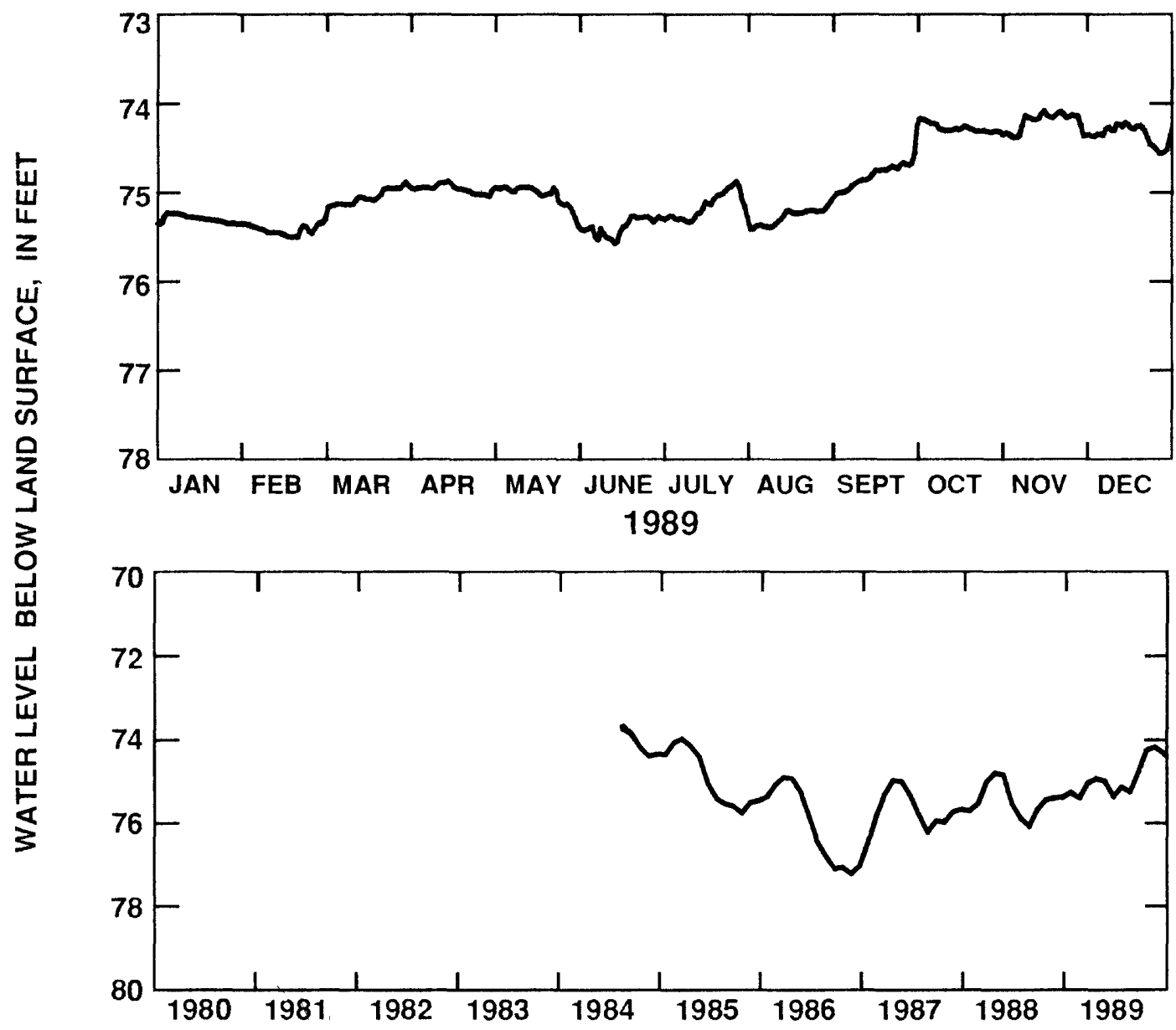

\begin{tabular}{|c|c|c|c|c|c|c|c|c|c|c|c|c|}
\hline 1989 & JAN & FEB & MAR & APR & MAY & JUN & JUL & $A \cup G$ & SEP & OCT & NOV & DEC \\
\hline $\begin{array}{l}\text { MEAN } \\
\text { MAX } \\
\text { MIN }\end{array}$ & $\begin{array}{l}75.30 \\
75.35 \\
75.22\end{array}$ & $\begin{array}{l}75.43 \\
75.50 \\
75.34\end{array}$ & $\begin{array}{l}75.07 \\
75.34 \\
74.88\end{array}$ & $\begin{array}{l}74.96 \\
75.04 \\
74.87\end{array}$ & $\begin{array}{l}75.02 \\
75.30 \\
74.94\end{array}$ & $\begin{array}{l}75.39 \\
75.58 \\
75.27\end{array}$ & $\begin{array}{l}75.16 \\
75.34 \\
74.88\end{array}$ & $\begin{array}{l}75.28 \\
75.42 \\
75.10\end{array}$ & $\begin{array}{l}74.82 \\
75.05 \\
74.57\end{array}$ & $\begin{array}{l}74.28 \\
74.33 \\
74.17\end{array}$ & $\begin{array}{l}74.21 \\
74.39 \\
74.09\end{array}$ & $\begin{array}{l}74.36 \\
74.58 \\
74.23\end{array}$ \\
\hline CAL YI & 1989 & & MEAN & 74.94 & & $\mathrm{HIGH}$ & 74.09 & & LOW & 75.58 & & \\
\hline
\end{tabular}

Figure 66.--Water level in observation well 06K010, Early County. 
310428084310501 Local number, 09G001.

LOCATION.--Lat $31^{\circ} 04^{\prime} 28^{\prime \prime}$, long 84 31'05", Hydrologic Unit 03130008, westernmost of two recorder wells, $2,500 \mathrm{ft}$ east of $\mathrm{Ga}$. highway $253,0.2 \mathrm{mi}$ south of the Decatur-Baker County line.

Owner: Earl Nichols, U.S. Geological Survey test well DP-4.

AQUIFER.--Claiborne.

WELL CHARACTERISTICS.--Drilled observation well, diameter 4 in., depth $455 \mathrm{ft}$, cased to $382 \mathrm{ft}$, open hole.

DATUM.--Altitude of land-surface datum is $145 \mathrm{ft}$.

Measuring point: Top of recorder shelf, $3.1 \mathrm{ft}$ above land-surface datum.

REMARKS.--Well pumped and redeveloped August 10, 1989.

PERIOD OF RECORD.--February 20, 1980 to current year.

EXTREMES FOR PERIOD OF RECORD.--Highest water level, $41.3 \mathrm{ft}$ below land-surface datum, April 8, 1980; lowest,

56.41 below land-surface datum, October $20,1981$.

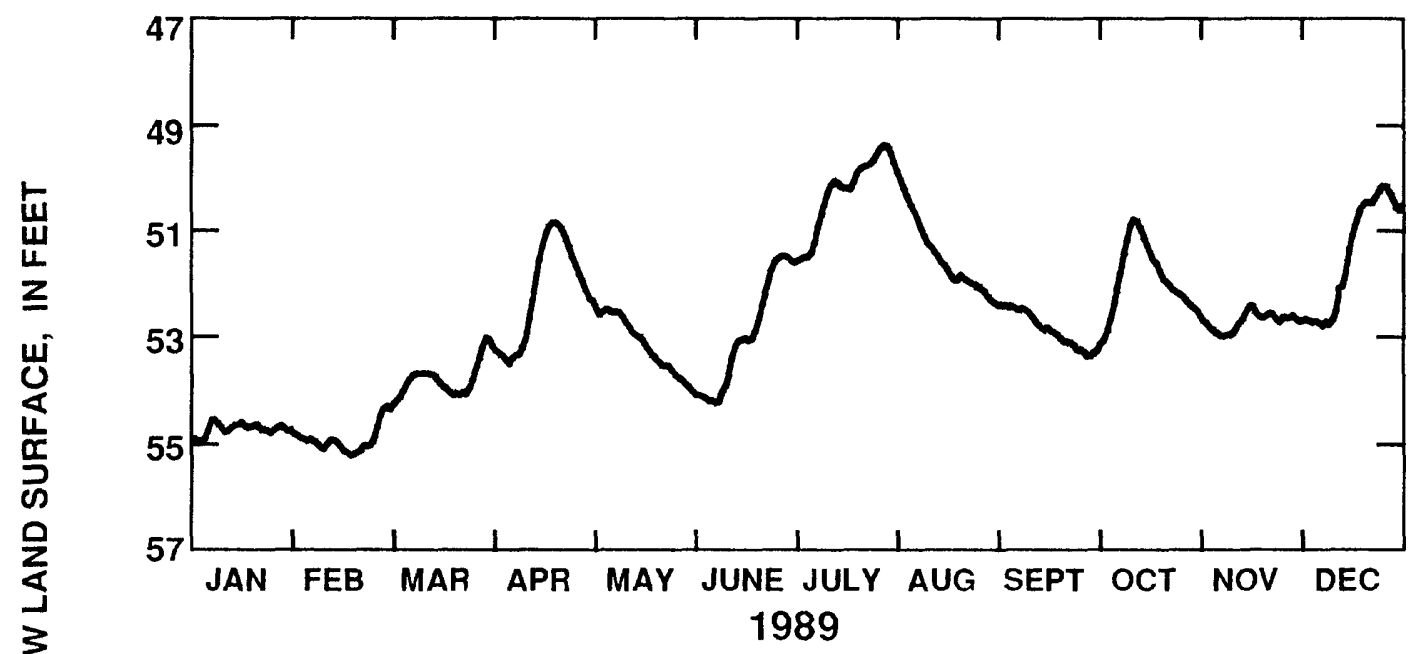

峞

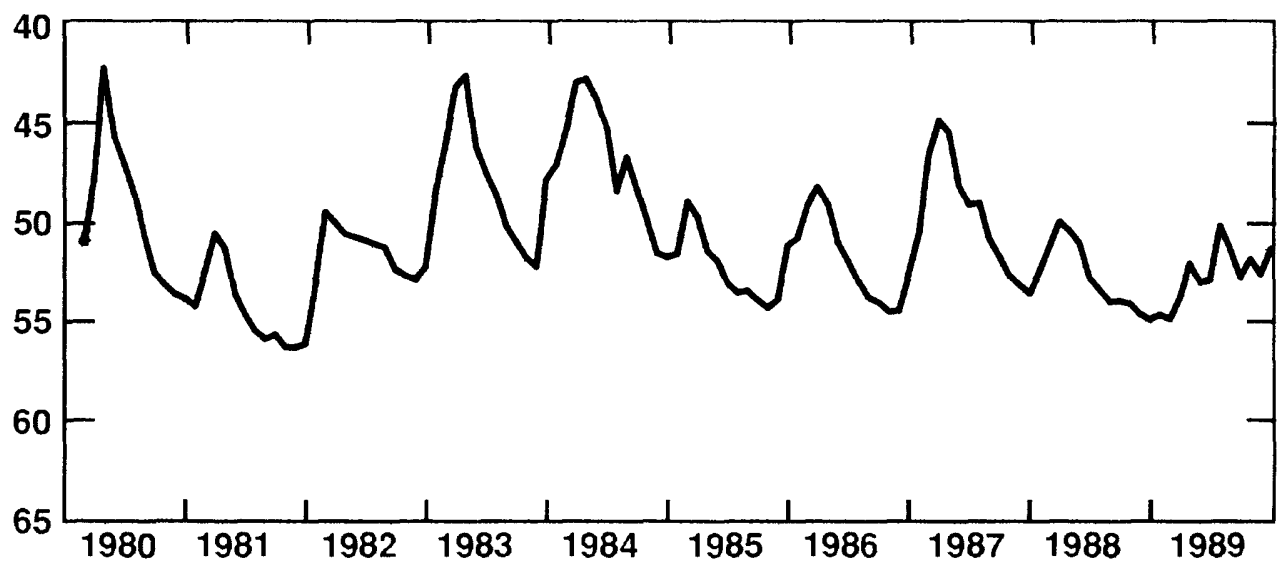

\begin{tabular}{|c|c|c|c|c|c|c|c|c|c|c|c|c|}
\hline 1989 & JAN & FEB & MAR & APR & MAY & JUN & JUL & $A \cup G$ & SEP & OCT & NOV & DEC \\
\hline $\begin{array}{l}\text { MEAN } \\
\text { MAX } \\
\text { MIN }\end{array}$ & $\begin{array}{l}54.74 \\
55.00 \\
54.56\end{array}$ & $\begin{array}{l}54.96 \\
55.23 \\
54.32\end{array}$ & $\begin{array}{l}53.83 \\
54.36 \\
53.02\end{array}$ & $\begin{array}{l}52.17 \\
53.52 \\
50.81\end{array}$ & $\begin{array}{l}53.13 \\
54.05 \\
52.31\end{array}$ & $\begin{array}{l}53.01 \\
54.26 \\
51.46\end{array}$ & $\begin{array}{l}50.29 \\
51.59 \\
49.35\end{array}$ & $\begin{array}{l}51.48 \\
52.43 \\
49.86\end{array}$ & $\begin{array}{l}52.90 \\
53.41 \\
52.42\end{array}$ & $\begin{array}{l}51.95 \\
53.17 \\
50.79\end{array}$ & $\begin{array}{l}52.76 \\
53.04 \\
52.46\end{array}$ & $\begin{array}{l}51.47 \\
52.85 \\
50.17\end{array}$ \\
\hline CAL YR & 1989 & & MEAN & 52.71 & & HIGH & 49.35 & & LOW & 55.23 & & \\
\hline
\end{tabular}

Figure 67.--Water level in observation well 09G001, Decatur County. 
$31395308436120 \mathrm{I}$ Local number, 09M009.

LOCATION.--Lat 31 $39^{\prime} 52^{\prime \prime}$, long $84^{\circ} 36^{\prime} 10^{\prime \prime}$, Hydrologic Unit 03130009 , easternmost of two observation wells, 0.2 mi east of Ga. Highway $41,7.2 \mathrm{mi}$ south of the intersection of U.S. Highway 82 and Ga. Highway 41 in Shellman.

Owner: C.T. Martin test well 1.

AQUIFER.--Claiborne.

WELL CHARACTERISTICS.--Drilled observation well, diameter 4 in., depth $94 \mathrm{ft}$, cased to $77 \mathrm{ft}$, screen to $94 \mathrm{ft}$.

DATUM.--Altitude of land-surface datum is $322 \mathrm{ft}$.

Measuring point: Top of recorder shelf, $3.27 \mathrm{ft}$ above land-surface datum.

REMARKS.--Well pumped and redeveloped August 8, 1989.

PERIOD OF RECORD.--September 14, 1984 to current year.

EXTREMES FOR PERIOD OF RECORD.--Highest water level, $25.75 \mathrm{ft}$ below land-surface datum, April 6, 1987: lowest, $30.50 \mathrm{ft}$ below land-surface datum, November 3, 1986.

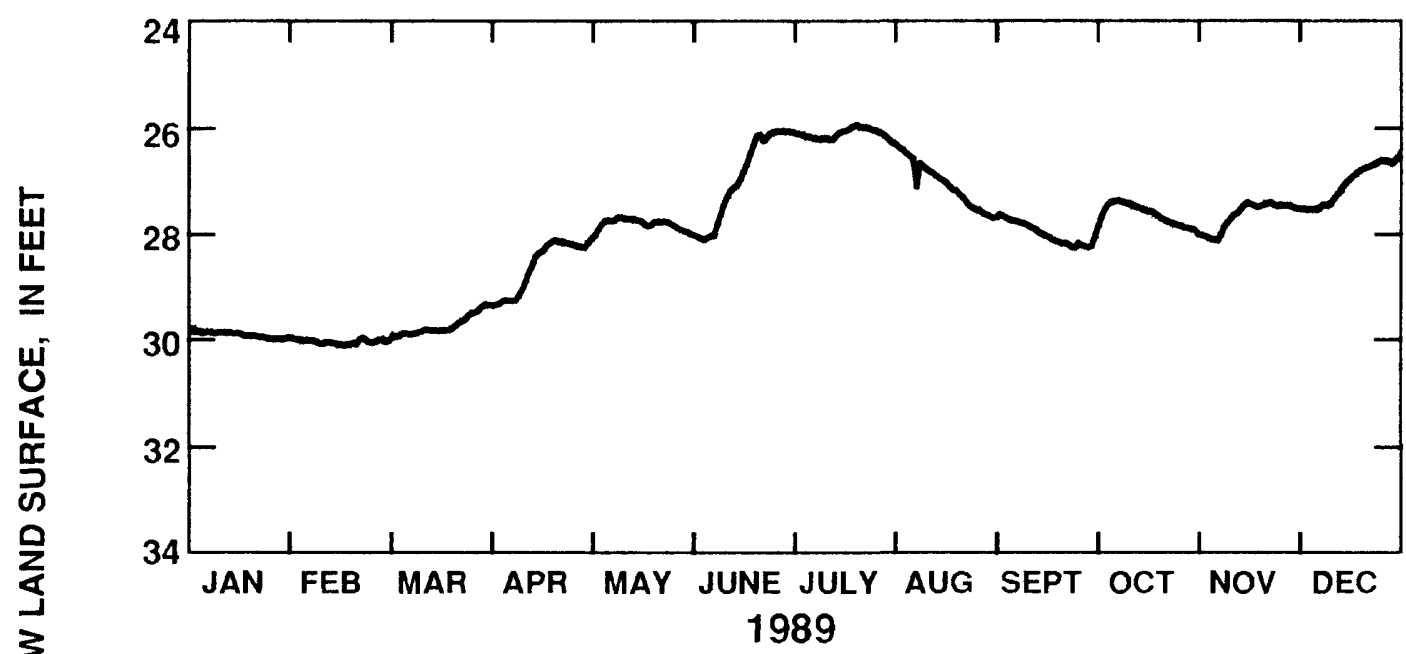

耑

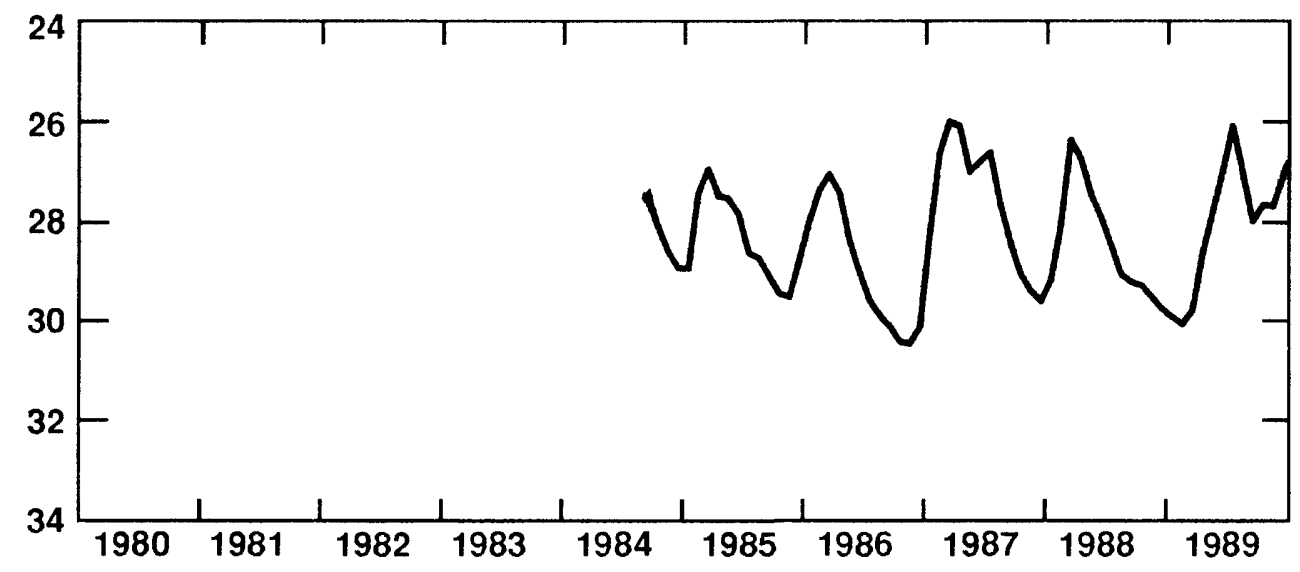

\begin{tabular}{|c|c|c|c|c|c|c|c|c|c|c|c|c|}
\hline 1989 & JAN & FEB & MAR & APR & MAY & JUN & JUL & AUG & SEP & OCT & NOV & DEC \\
\hline $\begin{array}{l}\text { MEAN } \\
\text { MAX } \\
\text { MIN }\end{array}$ & $\begin{array}{l}29.92 \\
30.01 \\
29.83\end{array}$ & $\begin{array}{l}30.07 \\
30.13 \\
29.99\end{array}$ & $\begin{array}{l}29.79 \\
30.06 \\
29.35\end{array}$ & $\begin{array}{l}28.67 \\
29.37 \\
28.13\end{array}$ & $\begin{array}{l}27.83 \\
28.17 \\
27.70\end{array}$ & $\begin{array}{l}27.02 \\
28.13 \\
26.06\end{array}$ & $\begin{array}{l}26.11 \\
26.24 \\
25.95\end{array}$ & $\begin{array}{l}27.05 \\
27.73 \\
26.30\end{array}$ & $\begin{array}{l}28.02 \\
28.29 \\
27.66\end{array}$ & $\begin{array}{l}27.68 \\
28.08 \\
27.40\end{array}$ & $\begin{array}{l}27.71 \\
28.17 \\
27.45\end{array}$ & $\begin{array}{l}27.12 \\
27.60 \\
26.62\end{array}$ \\
\hline CAL Y & 1989 & & MEAN & 28.07 & & HIGH & 25.95 & & LOW & 30.13 & & \\
\hline
\end{tabular}

Figure 68.--Water level in observation well 09M009, Randolph County. 
315731083542302 Local number, $14 \mathrm{P015}$.

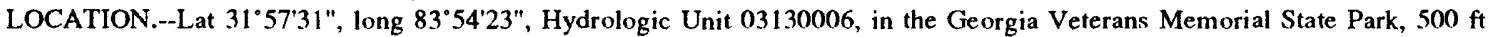
east of park maintenance facility, about 7.5 mi west of Cordele on U.S. Highway 280.

Owner: Georgia Geologic Survey, Veterans Memorial State Park test well 2.

AQUIFER.-. Claiborne.

WELL CHARACTERISTICS.--Drilled observation well, diameter 6 in., depth $340 \mathrm{ft}$, cased to $240 \mathrm{ft}$, screen to $340 \mathrm{ft}$.

DATUM.--Altitude of land-surface datum is $252 \mathrm{ft}$.

Measuring point: Top of recorder shelf, $3.0 \mathrm{ft}$ above land-surface datum.

REMARKS.--Aquifer test conducted on April 22, 1982. Well Pumped and sampled by Georgia Geologic Survey, March $22,1989$.

PERIOD OF RECORD.--August 30, 1984 to current year.

EXTREMES FOR PERIOD OF RECORD.--Highest water level, $12.97 \mathrm{ft}$ below land-surface datum, March 9, 1987; lowest,

$34.27 \mathrm{ft}$ below land-surface datum, August 29, 1986.

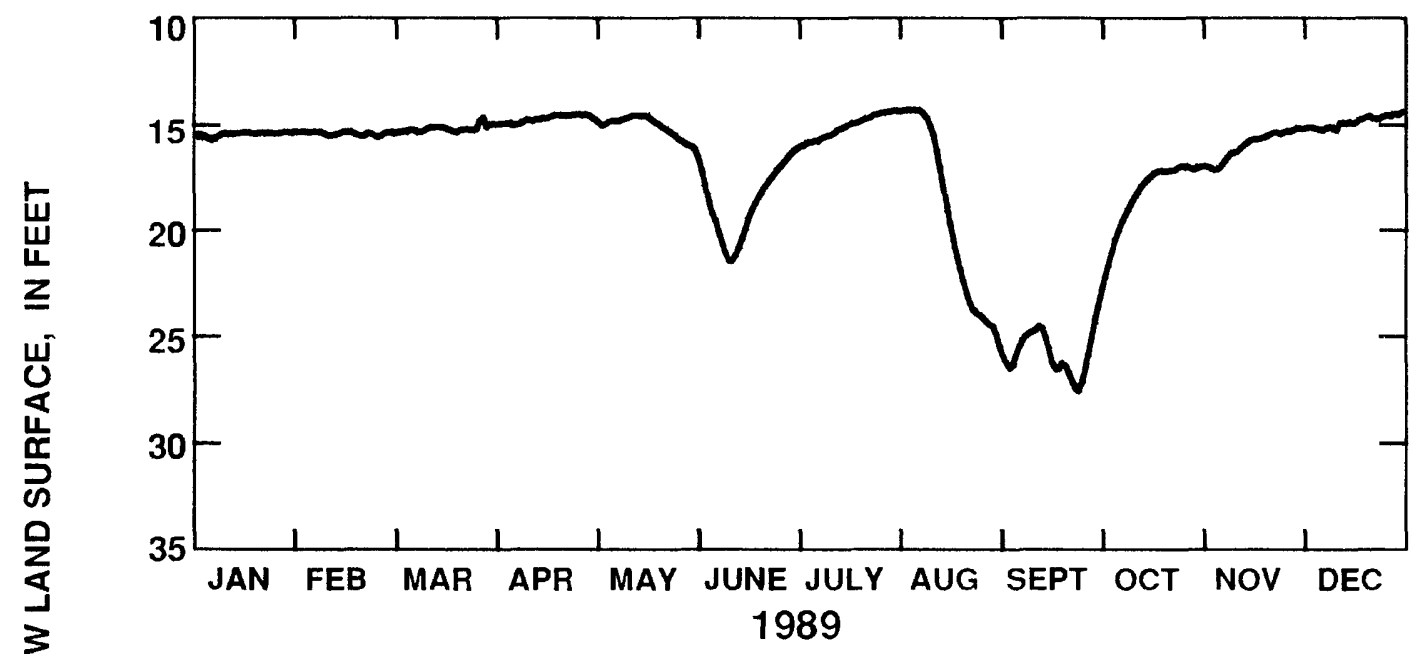

崖

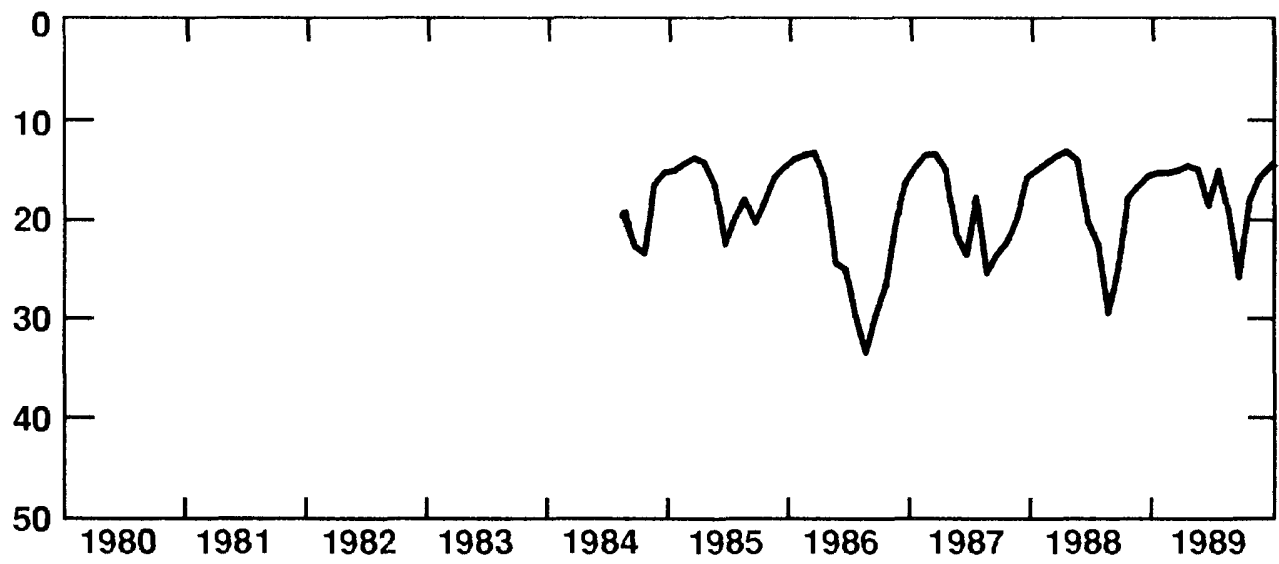

\begin{tabular}{|c|c|c|c|c|c|c|c|c|c|c|c|c|}
\hline 1989 & JAN & FEB & MAR & APR & MAY & JUN & JUL & AUG & SEP & OCT & NOV & DEC \\
\hline $\begin{array}{l}\text { MEAN } \\
\text { MAX } \\
\text { MIN }\end{array}$ & $\begin{array}{l}15.44 \\
15.72 \\
15.32\end{array}$ & $\begin{array}{l}15.42 \\
15.60 \\
15.33\end{array}$ & $\begin{array}{l}15.20 \\
15.40 \\
14.66\end{array}$ & $\begin{array}{l}14.74 \\
15.05 \\
14.53\end{array}$ & $\begin{array}{l}15.09 \\
16.18 \\
14.57\end{array}$ & $\begin{array}{l}18.71 \\
21.53 \\
16.22\end{array}$ & $\begin{array}{l}15.14 \\
16.12 \\
14.37\end{array}$ & $\begin{array}{l}19.46 \\
25.59 \\
14.33\end{array}$ & $\begin{array}{l}25.91 \\
27.66 \\
23.73\end{array}$ & $\begin{array}{l}18.41 \\
22.98 \\
17.00\end{array}$ & $\begin{array}{l}16.04 \\
17.19 \\
15.22\end{array}$ & $\begin{array}{l}14.93 \\
15.31 \\
14.46\end{array}$ \\
\hline CAL $Y$ & 1989 & & MEAN & 17.03 & & $\mathrm{HIGH}$ & 14.33 & & LOW & 27.66 & & \\
\hline
\end{tabular}

Figure 69.--Water level in observation well 14P015, Crisp County. 
321110083462701 Local number, 15R007.

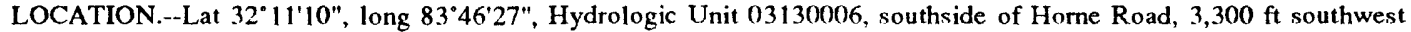

of intersection of Horne Road and U.S. Highway 41.

Owner: William Horne.

AQUIFER.--Claiborne.

WELL CHARACTERISTICS.--Drilled observation well, diameter 6 in., depth $330 \mathrm{ft}$, cased to $241 \mathrm{ft}$, screen from

241 to $309 \mathrm{ft}$, cased from 309 to $330 \mathrm{ft}$.

DATUM.--Altitude of land-surface datum is $412 \mathrm{ft}$.

Measuring point: Top of recorder shelf, $3.0 \mathrm{ft}$ above land-surface datum.

REMARKS.--Borehole geophysical survey conducted May 6, 1982. Aquifer test conducted May 21, 1982. Water levels for periods of missing record, May 25 to June 5, and August 15-23, were estimated.

PERIOD OF RECORD.--October 1, 1984 to current year.

EXTREMES FOR PERIOD OF RECORD.--Highest water level, $76.71 \mathrm{ft}$ helow land-surface datum, April 17, 1987; lowest, $96.25 \mathrm{ft}$ below land-surface datum, August 22, 1986.

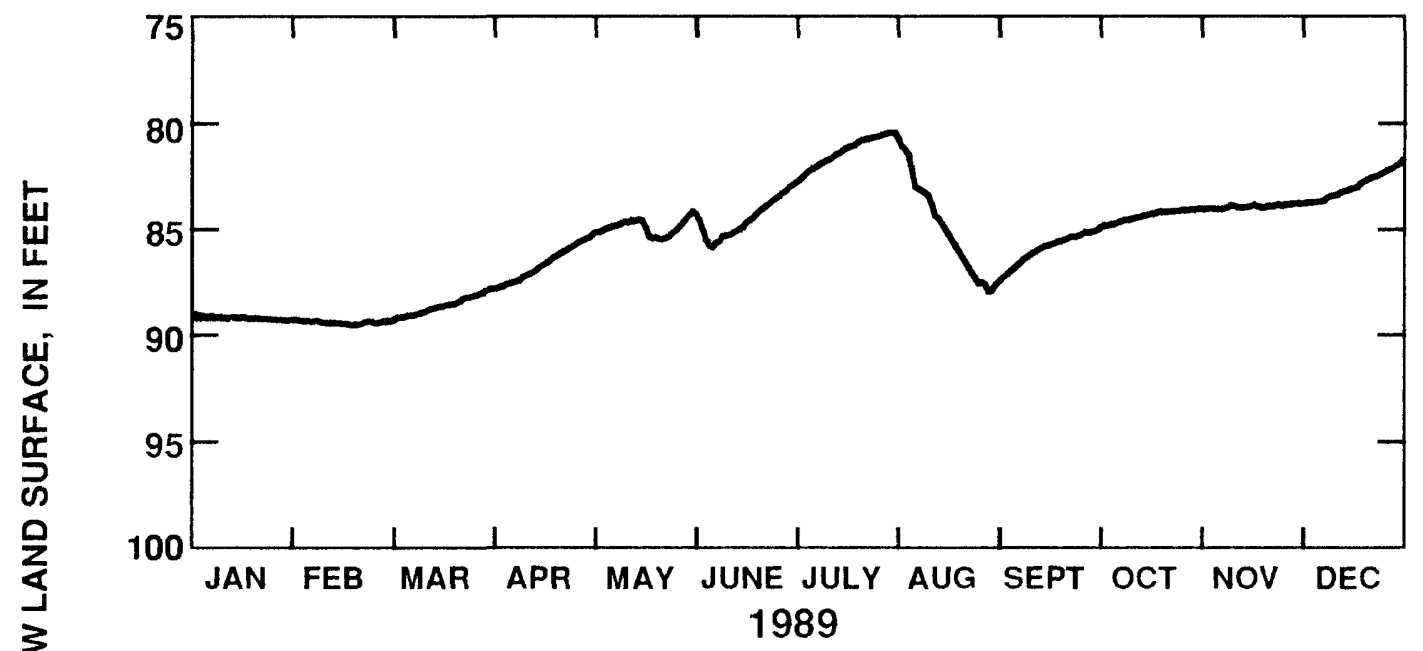

岗

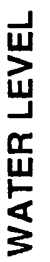

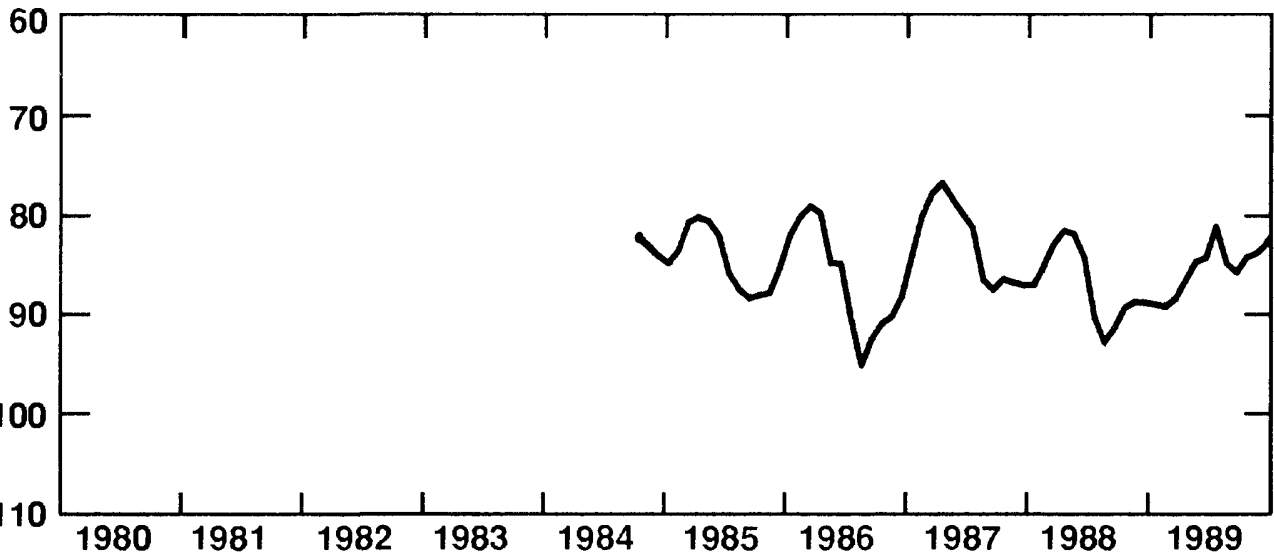

\begin{tabular}{|c|c|c|c|c|c|c|c|c|c|c|c|c|}
\hline 1989 & JAN & FEB & MAR & APR & MAY & JUN & JUL & AUG & SEP & OCT & NOV & DEC \\
\hline $\begin{array}{l}\text { MEAN } \\
\text { MAX } \\
\text { MIN }\end{array}$ & $\begin{array}{l}89.15 \\
89.27 \\
89.03\end{array}$ & $\begin{array}{l}89.37 \\
89.49 \\
89.25\end{array}$ & $\begin{array}{l}88.60 \\
89.30 \\
87.79\end{array}$ & $\begin{array}{l}86.65 \\
87.79 \\
85.34\end{array}$ & $\begin{array}{l}84.89 \\
85.44 \\
84.13\end{array}$ & $\begin{array}{l}84.48 \\
85.84 \\
82.88\end{array}$ & $\begin{array}{l}81.31 \\
82.76 \\
80.41\end{array}$ & $\begin{array}{l}85.03 \\
87.99 \\
80.68\end{array}$ & $\begin{array}{l}85.96 \\
87.38 \\
85.08\end{array}$ & $\begin{array}{l}84.41 \\
84.94 \\
84.09\end{array}$ & $\begin{array}{l}84.00 \\
84.12 \\
83.87\end{array}$ & $\begin{array}{l}83.03 \\
83.86 \\
81.80\end{array}$ \\
\hline :AL $Y$ & 1989 & & MEAN & 85.55 & & $\mathrm{HIGH}$ & 80.41 & & LOW & 89.49 & & \\
\hline
\end{tabular}

Figure 70.--Water level in observation well 15R007, Dooly County. 
313105084064301 Local number, 13L011.

LOCATION.--Lat $31^{\circ} 31^{\prime} 05^{\prime \prime}$, long $84^{\circ} 06^{\prime} 43^{\prime \prime}$, Hydrologic Unit 03130008 , about 6.5 mi southeast of Albany, east of U.S.

Highway 19 on dirt road, 0.1 mi north of School Bus Road.

Owner: U.S. Geological Survey test well 2.

AQUIFER.--Claiborne.

WELL CHARACTERISTICS.--Drilled observation well, diameter $4 \mathrm{in}$, depth $418 \mathrm{ft}$, cased to $398 \mathrm{ft}$, screen to $418 \mathrm{ft}$.

DATUM.--Altitude of land-surface datum is $195 \mathrm{ft}$.

Measuring point: Top of recorder shelf, $3.0 \mathrm{ft}$ above land-surface datum.

REMARKS.--Well pumped and redeveloped August 16, 1988.

PERIOD OF RECORD.--June 1977 to current year.

EXTREMES FOR PERIOD OF RECORD.--Highest water leve1, $60.01 \mathrm{ft}$ below land-surface datum, April 5, 1978: lowest, $95.00 \mathrm{ft}$ below land-surface datum, August 9-11, 1981.

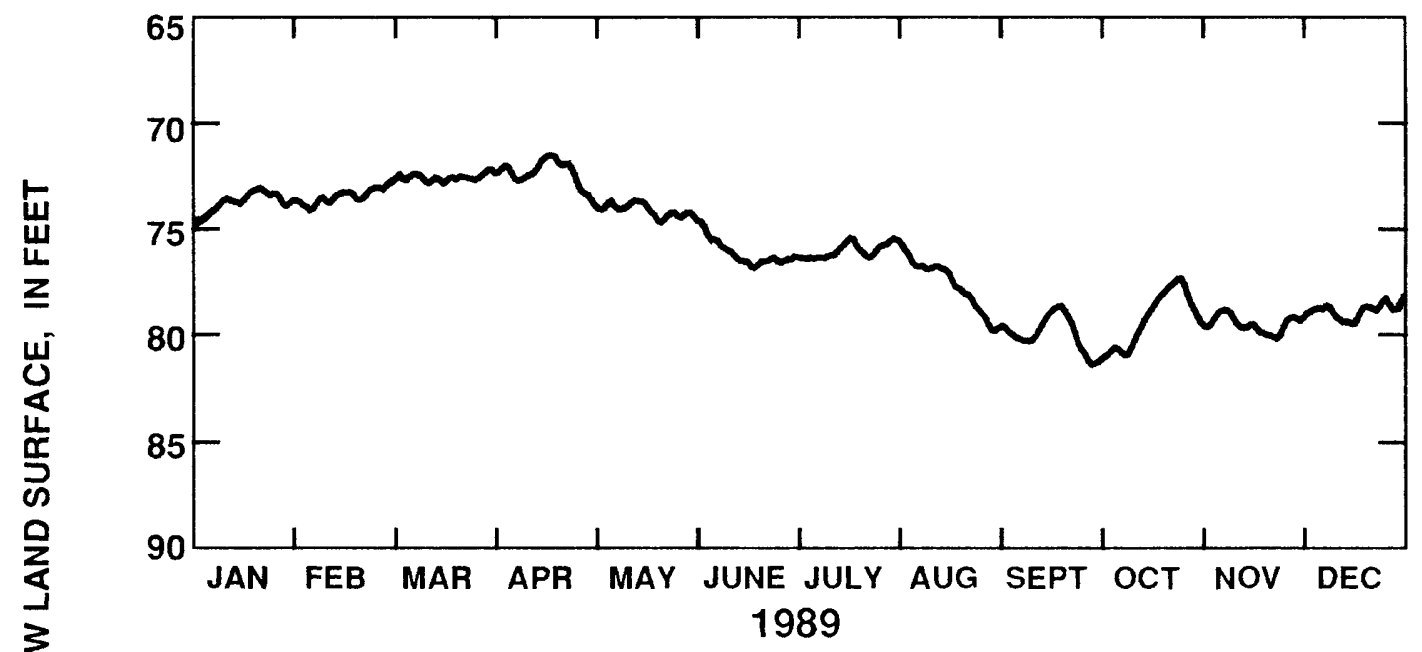

崖

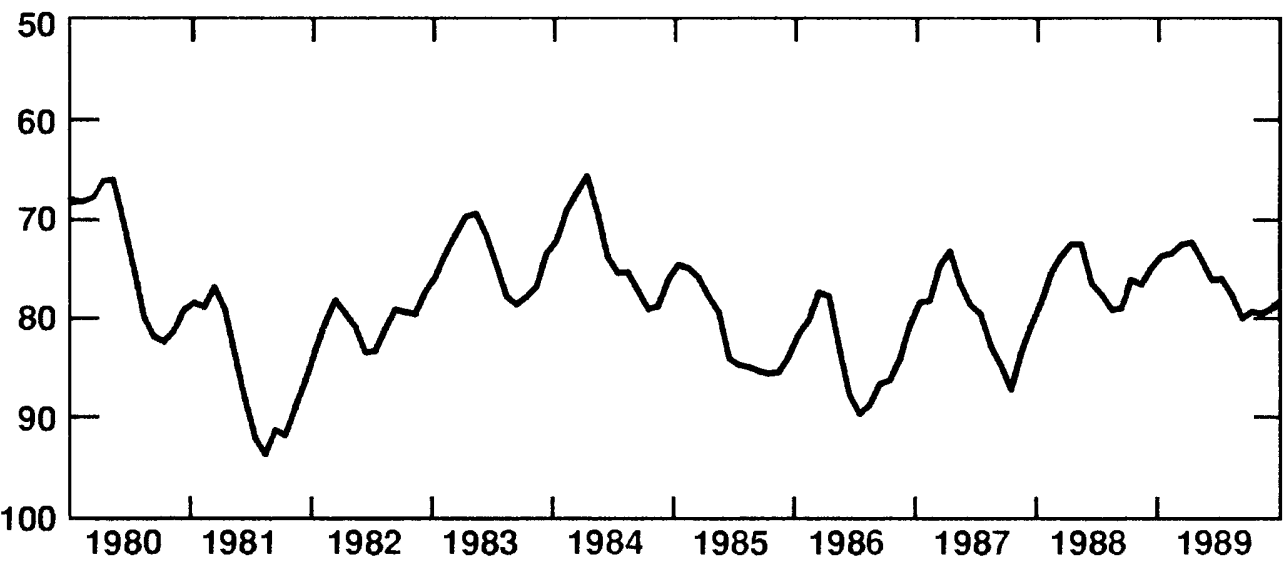

\begin{tabular}{|c|c|c|c|c|c|c|c|c|c|c|c|c|}
\hline 1989 & JAN & FEB & MAR & APR & MAY & JUN & JUL & AUG & SEP & OCT & NOV & DEC \\
\hline $\begin{array}{l}\text { MEAN } \\
\text { MAX }\end{array}$ & $\begin{array}{l}73.76 \\
74.69\end{array}$ & $\begin{array}{l}73.51 \\
74.18\end{array}$ & $\begin{array}{l}72.62 \\
72.87\end{array}$ & $\begin{array}{l}72.38 \\
73.66\end{array}$ & $\begin{array}{l}74.16 \\
74.73\end{array}$ & $\begin{array}{l}76.17 \\
76.87\end{array}$ & $\begin{array}{l}76.08 \\
76.45\end{array}$ & $\begin{array}{l}77.66 \\
79.88\end{array}$ & $\begin{array}{l}80.00 \\
81.48\end{array}$ & $\begin{array}{l}79.35 \\
81.20\end{array}$ & $\begin{array}{l}79.58 \\
80.25\end{array}$ & $\begin{array}{l}78.96 \\
79.57\end{array}$ \\
\hline MIN & 73.11 & 72.85 & 72.24 & 71.57 & 73.70 & 74.68 & 75.48 & 75.61 & 78.72 & 77.40 & 78.89 & 78.37 \\
\hline CAL & 1989 & & MEAN & 76.20 & & $\mathrm{HIGH}$ & 71.57 & & LOW & 81.48 & & \\
\hline
\end{tabular}

Figure 71.--Water level in observation well 13L011, Dougherty County. 
312654084210102 Local nunber, $11 \mathrm{~K} 002$.

LOCATION.--Lat $31^{\circ} 26^{\prime} 54^{\prime \prime}$, long $84^{\circ} 21^{\prime}\left(01^{\prime \prime}\right.$, Hydrologic Unit 03130008 , westernmost of two recorder wells, $50 \mathrm{ft}$ east of logging road, $0.65 \mathrm{mi}$ west and $0.65 \mathrm{mi}$ south of main gate into St. Joe Paper Company woodland on Tarva Road,

$3.6 \mathrm{mi}$ south of $\mathrm{Ga}$. Highway 62 , about $12 \mathrm{mi}$ west of Albany.

Owner: U.S. Geological Survey test well 11.

AQUIFER.--Claiborne.

WELL CHARACTERISTICS.--Drilled observation well, dianteter $4 \mathrm{in}$., depth $320 \mathrm{ft}$, cased to $300 \mathrm{ft}$, screen to $320 \mathrm{ft}$.

DATUM.--Altitude of land-surface datum is $183.5 \mathrm{ft}$.

Measuring point: Top of recorder shelf, $3.0 \mathrm{ft}$ above land-surface datum.

REMARKS.--Borehole geophysical survey conducted March 1 I, 1980.

PERIOD OF RECORD.--May 16, 1979 to current year.

EXTREMES FOR PERIOD OF RECORD.--Highest water level, $22.11 \mathrm{ft}$ below land-surface datum, June 1, 1979: lowest,

$28.04 \mathrm{ft}$ below land-surface datum, December 24, 1981.

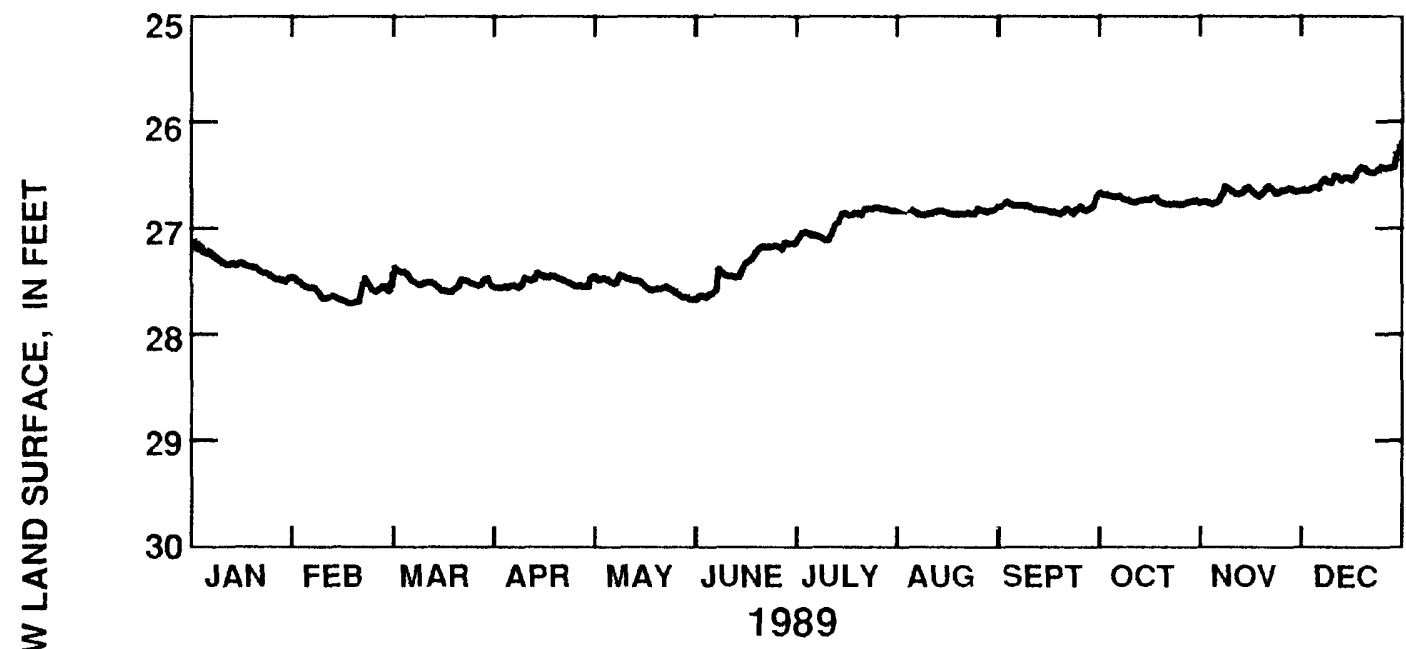

崫

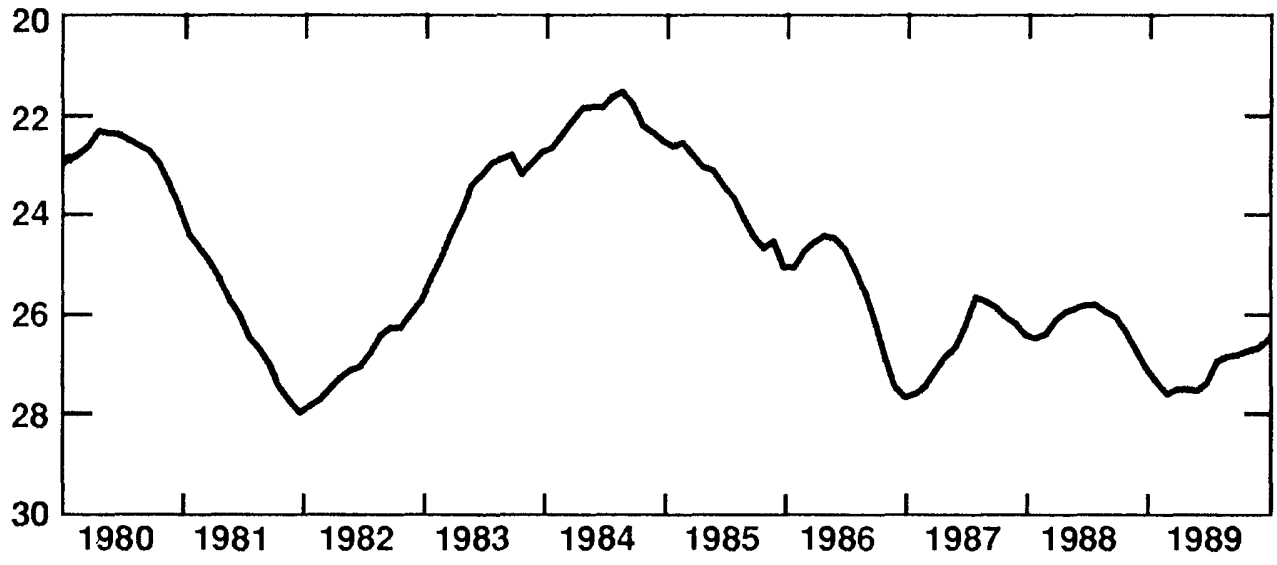

\begin{tabular}{|c|c|c|c|c|c|c|c|c|c|c|c|c|}
\hline 1989 & JAN & FEB & MAR & APR & MAY & JUN & JUL & AUG & SEP & OCT & NOV & DEC \\
\hline $\begin{array}{l}\text { MEAN } \\
\text { MAX } \\
\text { MIN }\end{array}$ & $\begin{array}{l}27.35 \\
27.50 \\
27.15\end{array}$ & $\begin{array}{l}27.60 \\
27.71 \\
27.47\end{array}$ & $\begin{array}{l}27.51 \\
27.60 \\
27.37\end{array}$ & $\begin{array}{l}27.51 \\
27.56 \\
27.42\end{array}$ & $\begin{array}{l}27.53 \\
27.67 \\
27.44\end{array}$ & $\begin{array}{l}27.38 \\
27.67 \\
27.13\end{array}$ & $\begin{array}{l}26.94 \\
27.14 \\
26.80\end{array}$ & $\begin{array}{l}26.84 \\
26.87 \\
26.81\end{array}$ & $\begin{array}{l}26.81 \\
26.86 \\
26.75\end{array}$ & $\begin{array}{l}26.73 \\
26.77 \\
26.66\end{array}$ & $\begin{array}{l}26.67 \\
26.77 \\
26.60\end{array}$ & $\begin{array}{l}26.51 \\
26.65 \\
26.29\end{array}$ \\
\hline CAL Y & 1989 & & MEAN & 27.11 & & $\mathrm{HIGH}$ & 26.29 & & LOW & 27.71 & & \\
\hline
\end{tabular}

Figure 72.--Water level in observation well $11 \mathrm{~K} 002$, Dougherty County. 
315353084192502 Local number, $11 \mathrm{P0} 15$.

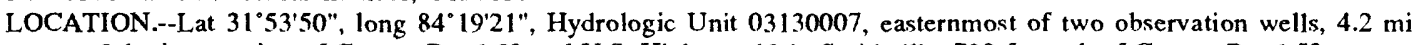
west of the intersection of County Road 53 and U.S. Highway 19 in Smithville, $700 \mathrm{ft}$ south of County Road 53.

Owner: Pete Long test well 2.

AQUIFER.--Claiborne.

WELL CHARACTERISTICS.--Drilled observation well, diameter 6 in., depth $151 \mathrm{ft}$, cased to $111 \mathrm{ft}$, screen to $151 \mathrm{ft}$.

DATUM.--Altitude of land-surface datum is $338 \mathrm{ft}$.

Measuring point: Top of recorder shelf, $3.2 \mathrm{ft}$ above land-surface datum .

REMARKS.--Well pumped and redeveloped August 7, 1989. Water levels for periods of missing record, February 23 to

March 26, and October 10-16, were estimated.

PERIOD OF RECORD.--September 14,1984 to current year.

EXTREMES FOR PERIOD OF RECORD.--Highest water level, $35.89 \mathrm{ft}$ below land-surface datum, September 14, 1984: lowest,

$39.66 \mathrm{ft}$ below land-surface datum, October $28,1986$.
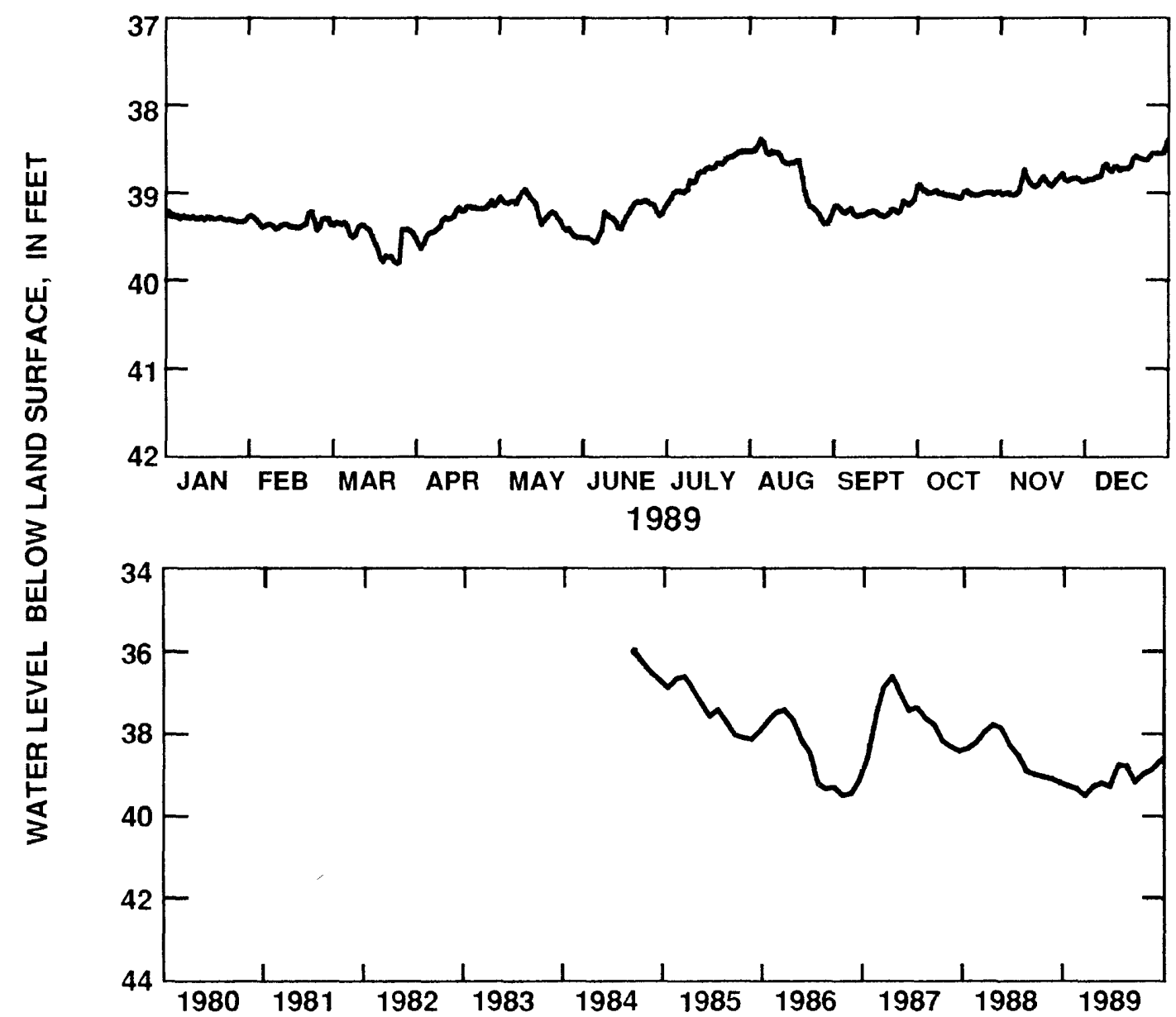

\begin{tabular}{|c|c|c|c|c|c|c|c|c|c|c|c|c|}
\hline 1989 & JAN & FEB & MAR & APR & MAY & JUN & JUL & AUG & SEP & OCT & NOV & DEC \\
\hline $\begin{array}{l}\text { MEAN } \\
\text { MAX } \\
\text { MIN }\end{array}$ & $\begin{array}{l}39.29 \\
39.33 \\
39.24\end{array}$ & $\begin{array}{l}39.35 \\
39.43 \\
39.22\end{array}$ & $\begin{array}{l}39.47 \\
39.63 \\
39.34\end{array}$ & $\begin{array}{l}39.30 \\
39.64 \\
39.09\end{array}$ & $\begin{array}{l}39.22 \\
39.51 \\
38.96\end{array}$ & $\begin{array}{l}39.30 \\
39.57 \\
39.09\end{array}$ & $\begin{array}{l}38.78 \\
39.17 \\
38.53\end{array}$ & $\begin{array}{l}38.80 \\
39.35 \\
38.39\end{array}$ & $\begin{array}{l}39.20 \\
39.27 \\
39.08\end{array}$ & $\begin{array}{l}39.01 \\
39.06 \\
38.91\end{array}$ & $\begin{array}{l}38.90 \\
39.03 \\
38.74\end{array}$ & $\begin{array}{l}38.69 \\
38.87 \\
38.46\end{array}$ \\
\hline CAL Y & 1989 & & MEAN & 39.11 & & $\mathrm{HIGH}$ & 38.39 & & LOW & 39.64 & & \\
\hline
\end{tabular}

Figure 73.--Water level in observation well 11P015, Lee County. 
314330084005401 Local number, $13 \mathrm{M005}$.

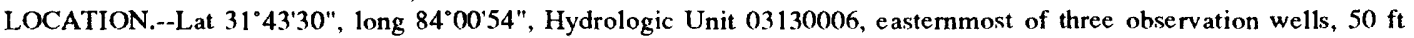
north of Ga. Highway 32, 1,400 ft east of the Flint River, $1.7 \mathrm{mi}$ east of the intersection of Ga. Highway 32 and Ga. Higliway 91. Owner: U.S. Geological Survey test well DP-7.

AQUIFER.--Claiborne.

WELL CHARACTERISTICS.--Drilled observation well, diameter 6 in., depth $345 \mathrm{ft}$, cased to $330 \mathrm{ft}$, screen to $345 \mathrm{ft}$. DATUM.--Altitude of land-surface datum is $230 \mathrm{ft}$.

Measuring point: Top of recorder shelf, $3.13 \mathrm{ft}$ above land-surface datum

REMARKS.--Borehole geophysical survey conducted March 16, 1982.

PERIOD OF RECORD.--April 22, 1980 to current year.

EXTREMES FOR PERIOD OF RECORD.--Highest water level, $2.89 \mathrm{ft}$ below land-surface datum, May 29, 1980; lowest,

$23.37 \mathrm{ft}$ below land-surface datum July 28,1981 .
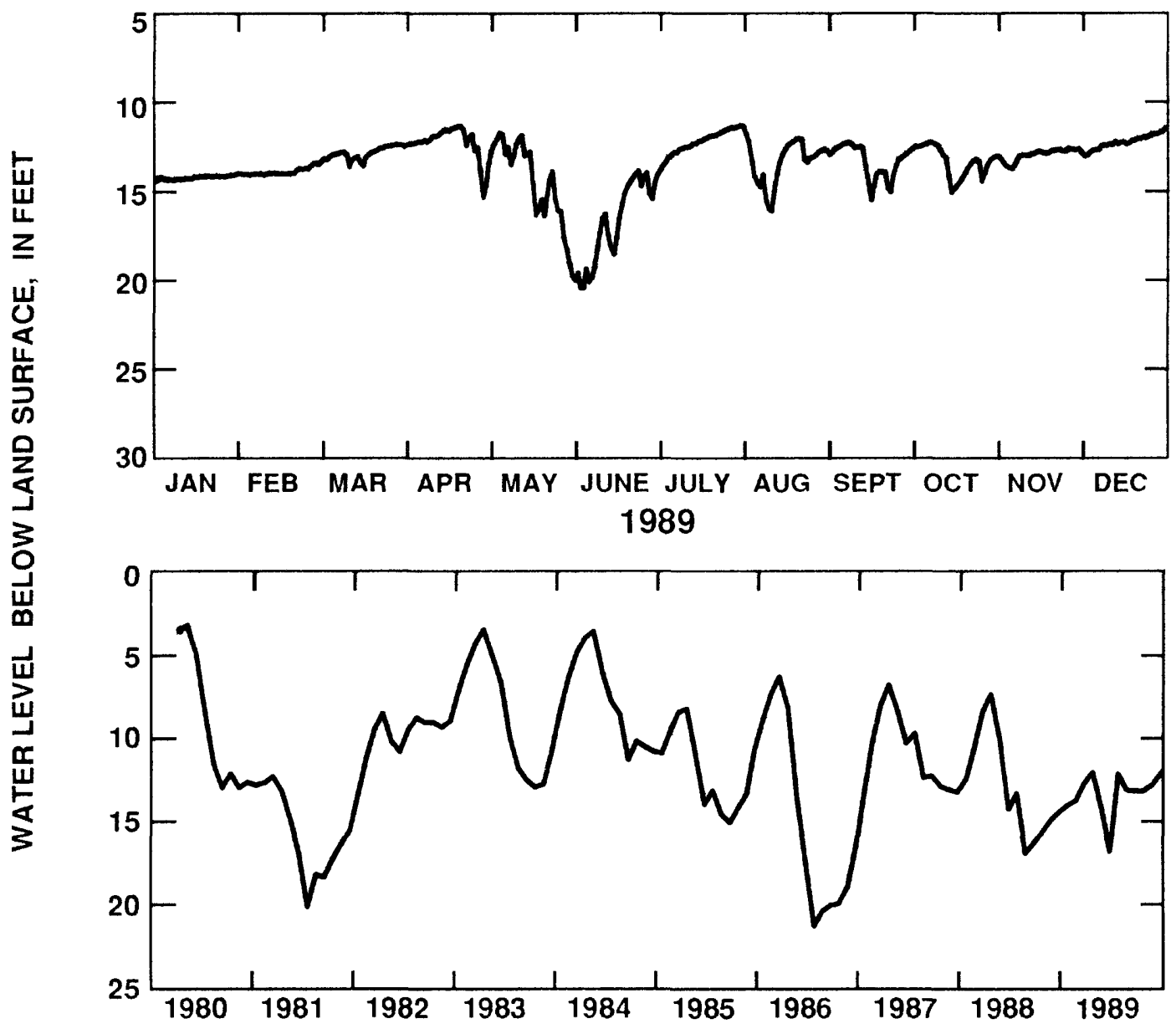

\begin{tabular}{|c|c|c|c|c|c|c|c|c|c|c|c|c|}
\hline 1989 & JAN & FEB & MAR & APR & MAY & JUN & JUL & AUG & SEP & OCT & NOV & DEC \\
\hline $\begin{array}{l}\text { MEAN } \\
\text { MAX }\end{array}$ & $\begin{array}{l}14.08 \\
14.21\end{array}$ & $\begin{array}{l}13.78 \\
13.95\end{array}$ & $\begin{array}{r}12.77 \\
13.50\end{array}$ & $\begin{array}{r}12.13 \\
15.24 \\
11.23\end{array}$ & $\begin{array}{l}14.29 \\
19.71 \\
11.6 ?\end{array}$ & $\begin{array}{l}16.80 \\
20.40 \\
13.77\end{array}$ & $\begin{array}{l}12.21 \\
13.97\end{array}$ & $\begin{array}{l}13.20 \\
16.04 \\
11.23\end{array}$ & $\begin{array}{l}13.25 \\
15.45 \\
12.20\end{array}$ & $\begin{array}{l}13.26 \\
15.04 \\
12.20\end{array}$ & $\begin{array}{l}12.93 \\
13.71 \\
12.60\end{array}$ & $\begin{array}{l}12.25 \\
13.00 \\
11.47\end{array}$ \\
\hline MIN & 13.87 & 13.31 & 12.25 & 11.23 & 11.62 & 13.77 & 11.21 & 11.23 & 12.20 & 12.20 & 12.60 & 11.47 \\
\hline CAL YI & 1989 & & MEAN & 13.41 & & HIGH & 11.21 & & Low & 20.40 & & \\
\hline
\end{tabular}

Figure 74.--Water level in observation well 13M005, Worth County. 


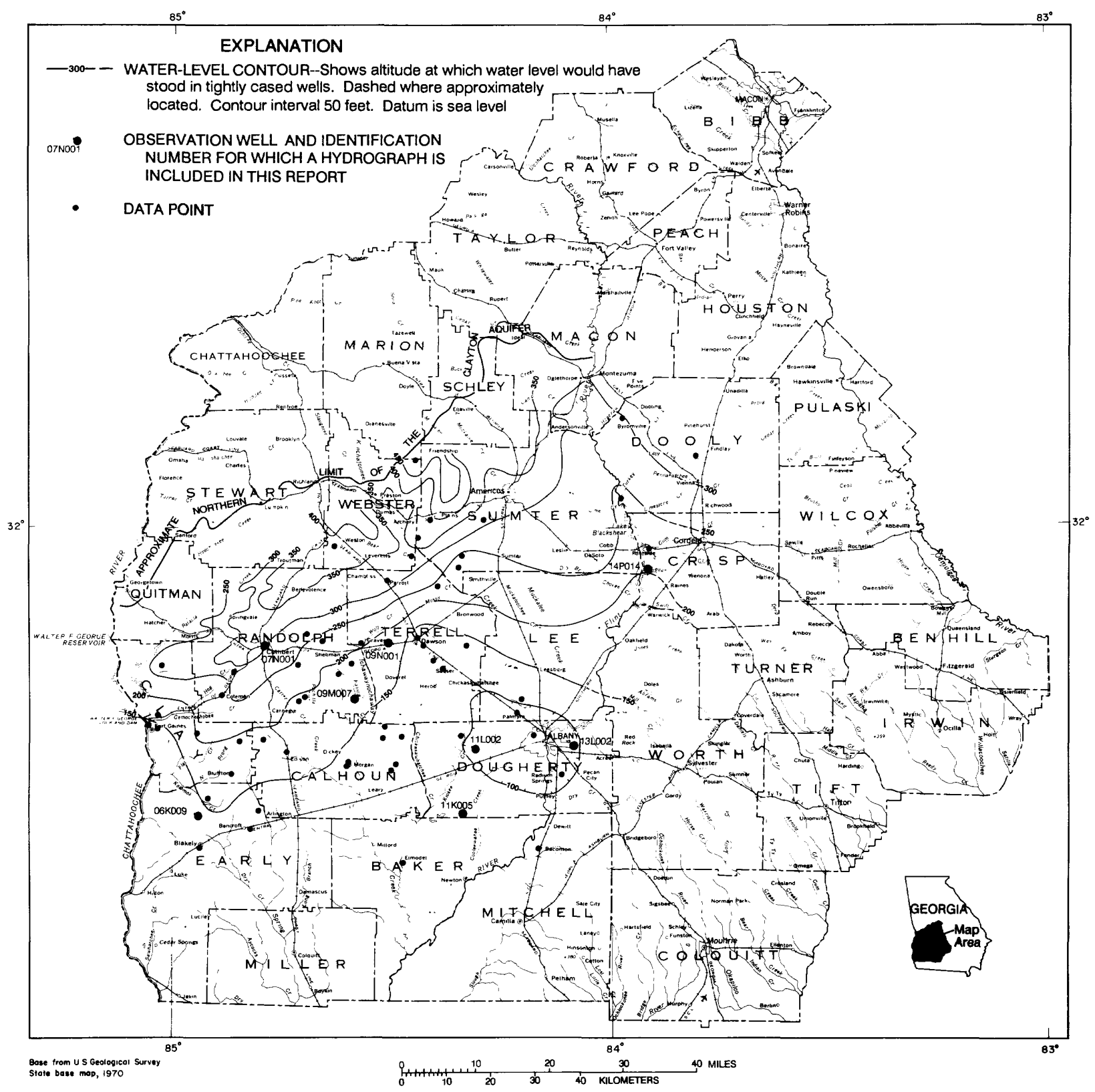

Figure 75.--Water levels and locations of observation wells completed in the Clayton aquifer, November 1989. 
315731083542301 Local number, 14P014.

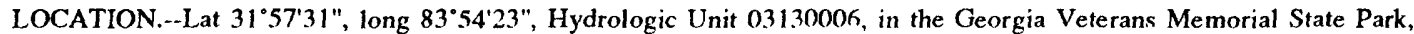

$500 \mathrm{ft}$ east of park maintenance facility, about $7.5 \mathrm{mi}$ west of Cordele on U.S. Highway 280.

Owner: Georgia Geologic Survey, Veterans Memorial Park test well 1.

AQUIFER.-.Clayton.

WELL CHARACTERISTICS.--Drilled observation well, diameter $6 \mathrm{in}$., depth $550 \mathrm{ft}$ cased to $500 \mathrm{ft}$, open hole.

DATUM.--Altitude of land-surface datum is $252 \mathrm{ft}$.

Measuring point: Top of recorder shelf, $3.1 \mathrm{ft}$ above land-surface datum.

REMARKS.--Well pumped May 20, 1982. Borehole geophysical survey conducted Fehruary $22,1982$.

PERIOD OF RECORD.--September 1984 to current year.

EXTREMES FOR PERIOD OF RECORD.--Highest water leve1, $37.16 \mathrm{ft}$ below land-surface datum, September 2, 1984; lowest, $49.26 \mathrm{ft}$ below land-surface datum, November $29,1988$.

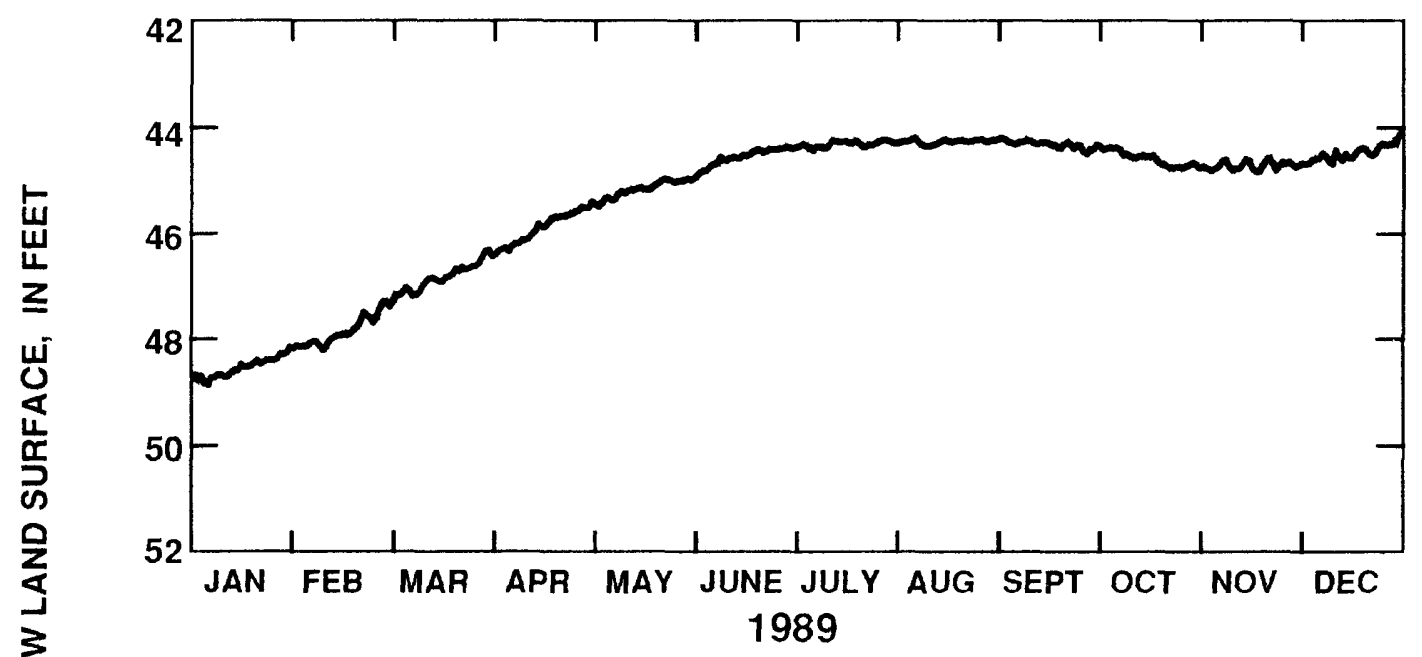

㟋

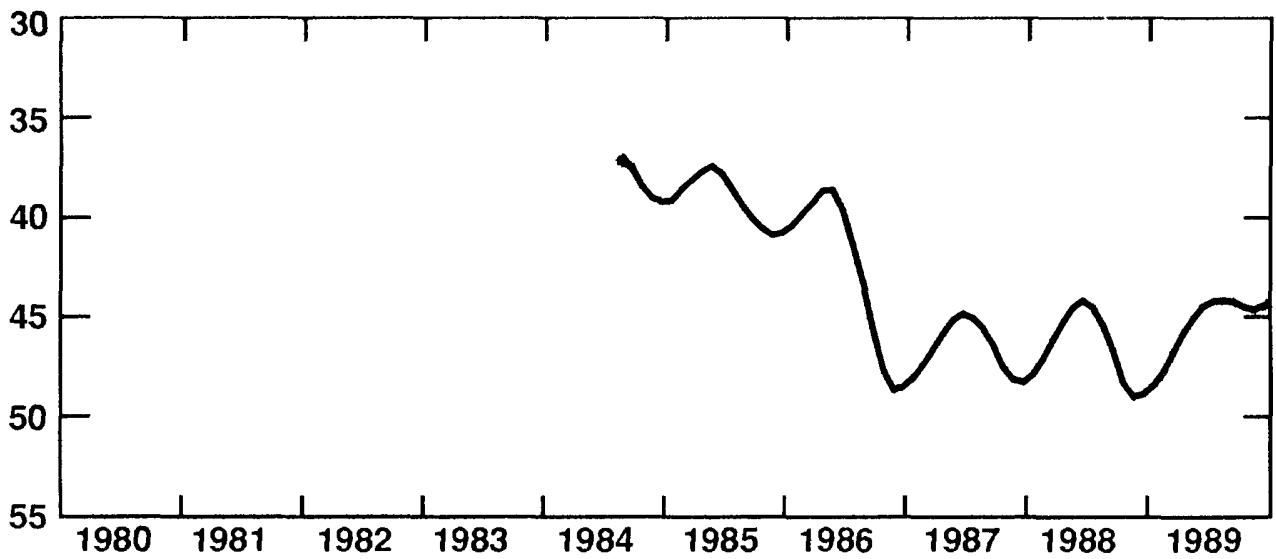

\begin{tabular}{|c|c|c|c|c|c|c|c|c|c|c|c|c|}
\hline 1989 & JAN & FEB & MAR & APR & MAY & JUN & JUL & AUG & SEP & OCT & NOV & DEC \\
\hline $\begin{array}{l}\text { MEAN } \\
\text { MAX } \\
\text { MIN }\end{array}$ & $\begin{array}{l}48.50 \\
48.83 \\
48.12\end{array}$ & $\begin{array}{l}47.82 \\
48.18 \\
47.25\end{array}$ & $\begin{array}{l}46.82 \\
47.34 \\
46.28\end{array}$ & $\begin{array}{l}45.89 \\
46.40 \\
45.46\end{array}$ & $\begin{array}{l}45.13 \\
45.45 \\
44.93\end{array}$ & $\begin{array}{l}44.53 \\
44.93 \\
44.33\end{array}$ & $\begin{array}{l}44.28 \\
44.40 \\
44.21\end{array}$ & $\begin{array}{l}44.24 \\
44.33 \\
44.17\end{array}$ & $\begin{array}{l}44.30 \\
44.48 \\
44.17\end{array}$ & $\begin{array}{l}44.56 \\
44.76 \\
44.31\end{array}$ & $\begin{array}{l}44.72 \\
44.83 \\
44.57\end{array}$ & $\begin{array}{l}44.50 \\
44.72 \\
44.16\end{array}$ \\
\hline ;AL Y & 1989 & & MEAN & 45.43 & & $\mathrm{HIGH}$ & 44.16 & & LOW & 48.83 & & \\
\hline
\end{tabular}

Figure 76.--Water level in observation well 14P014, Crisp County. 
314602084473701 Local number, 07 N001.

LOCATION.--Lat $31^{\circ} 46^{\circ} 09^{\prime \prime}$, long $84^{\circ} 47^{\prime} 43^{\prime \prime}$, Hydrologic Unit 03110204, south of intersection of College and Andrew

Streets, $200 \mathrm{ft}$ southwest of Cuthbert city supply well, near electric substation.

Owner: City of Cuthbert.

AQUIFER.--Clayton.

WELL CHARACTERISTICS.--Drilled unused municipal well, diameter 8 in., depth $372 \mathrm{ft}$, casing depth unknown.

DATUM.--Altitude of land-surface datum is $460 \mathrm{ft}$.

Measuring point: Top of recorder shelf, $3.30 \mathrm{ft}$ above land-surface datum.

REMARKS.--Well pumped and redeveloped August 8, 1989. Well near city wells. Water levels for period of missing record, January 16 to February 6 , were estimated.

PERIOD OF RECORD.--January 1965 to current year.

EXTREMES FOR PERIOD OF RECORD.--Highest water level, $132.0 \mathrm{ft}$ helow land-surface datum, December 10, 1967: lowest, $162.08 \mathrm{ft}$ below land-surface datum, August 4, 1986.

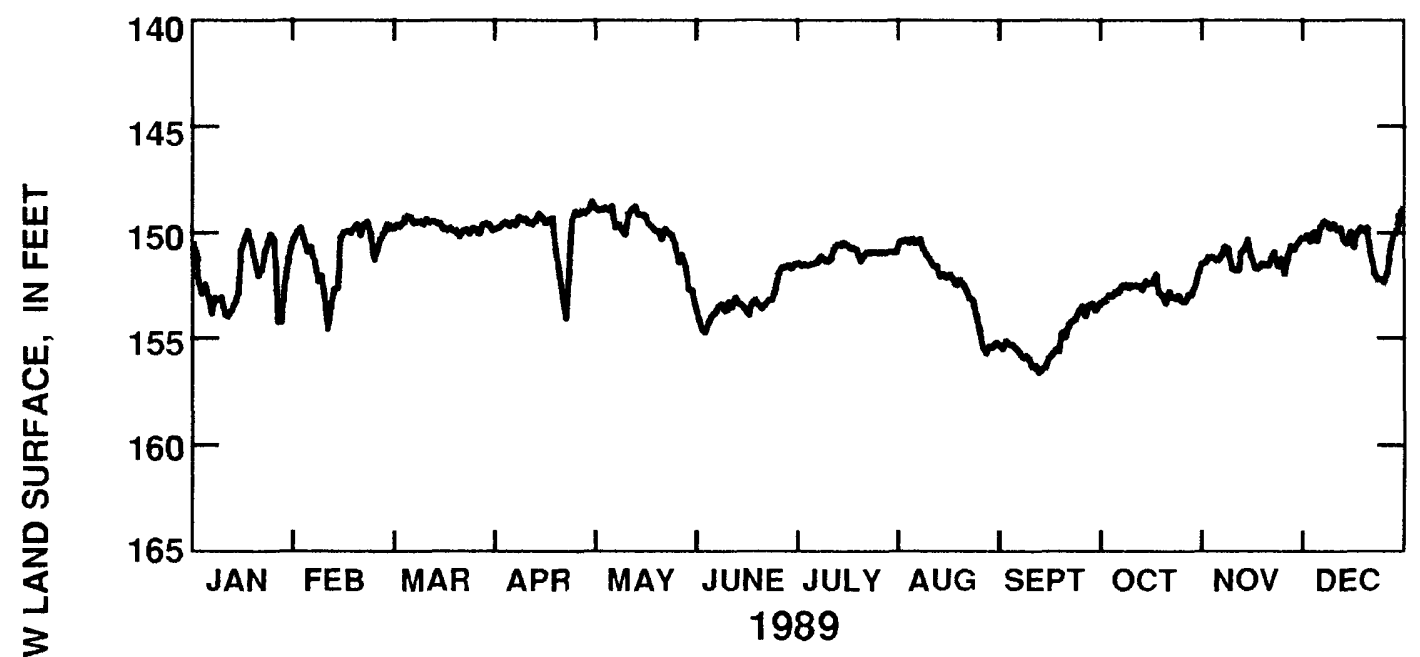

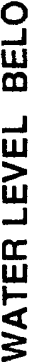

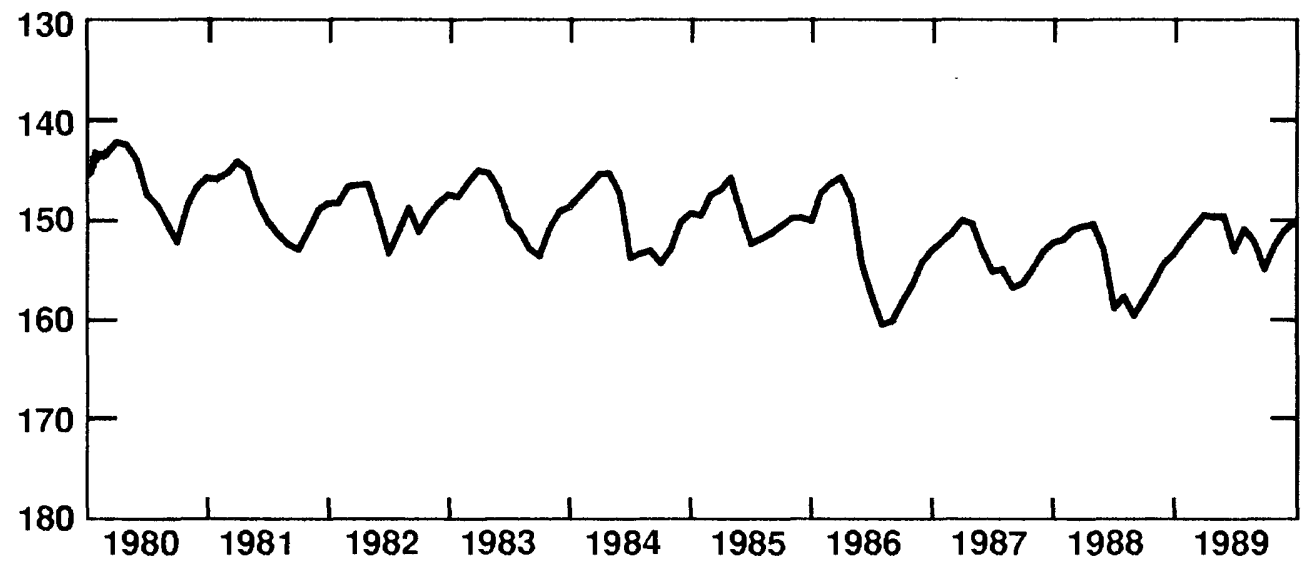

\begin{tabular}{|c|c|c|c|c|c|c|c|c|c|c|c|c|}
\hline 1989 & JAN & FEB & MAR & APR & MAY & JUN & JUL & $A \cup G$ & SEP & OCT & NOV & DEC \\
\hline $\begin{array}{l}\text { MEAN } \\
\text { MAX } \\
\text { MIN }\end{array}$ & $\begin{array}{l}152.09 \\
154.22 \\
149.89\end{array}$ & $\begin{array}{l}150.86 \\
154.57 \\
149.47\end{array}$ & $\begin{array}{l}149.67 \\
150.17 \\
149.20\end{array}$ & $\begin{array}{l}149.89 \\
154.06 \\
148.92\end{array}$ & $\begin{array}{l}149.84 \\
152.76 \\
148.55\end{array}$ & $\begin{array}{l}153.28 \\
154.72 \\
151.56\end{array}$ & $\begin{array}{l}151.07 \\
151.57 \\
150.49\end{array}$ & $\begin{array}{l}152.35 \\
155.73 \\
150.33\end{array}$ & $\begin{array}{l}155.18 \\
156.63 \\
153.42\end{array}$ & $\begin{array}{l}152.82 \\
153.48 \\
151.91\end{array}$ & $\begin{array}{l}151.26 \\
151.99 \\
150.37\end{array}$ & $\begin{array}{l}150.44 \\
152.40 \\
149.34\end{array}$ \\
\hline CAL Y & 'R 1989 & & MEAN & 151.5 & & $\mathrm{HIGH}$ & 148.5 & & LOW & 156.6 & & \\
\hline
\end{tabular}

Figure 77.--Water level in observation well 07N001, Randolph County. 
313953084361202 Local number, 09M007.

LOCATION.--Lat 31 39'52", long 84'36'12", Hydrologic Unit 03130009, westernmost of two observation wells, 0.2 mi east of Ga. Highway 41, 7.2 mi south of the intersection of U.S. Highway 82 and Ga. Highway 41 in Shellman.

Owner: C.T. Martin test well 2.

AQUIFER.--Clayton.

WELL CHARACTERISTICS.- Drilled observation well, diameter 6 in., depth $430 \mathrm{ft}$, cased to $356 \mathrm{ft}$, open hole.

DATUM.--Altitude of land-surface datum is $322 \mathrm{ft}$.

Measuring point: Top of recorder shelf, $3.25 \mathrm{ft}$ above land-surface datum.

REMARKS.--Borehole geophysical survey conducted April 15, 1980. Aquifer test conducted April 4, 1982. Well pumped and redeveloped August 8, 1989.

PERIOD OF RECORD.--September 14, 1984 to current year.

EXTREMES FOR PERIOD OF RECORD.--Highest water level, $126.55 \mathrm{ft}$ below land-surface datum, March 27, 1986: lowest, $212.90 \mathrm{ft}$ below land-surface datum, July $23,1986$.
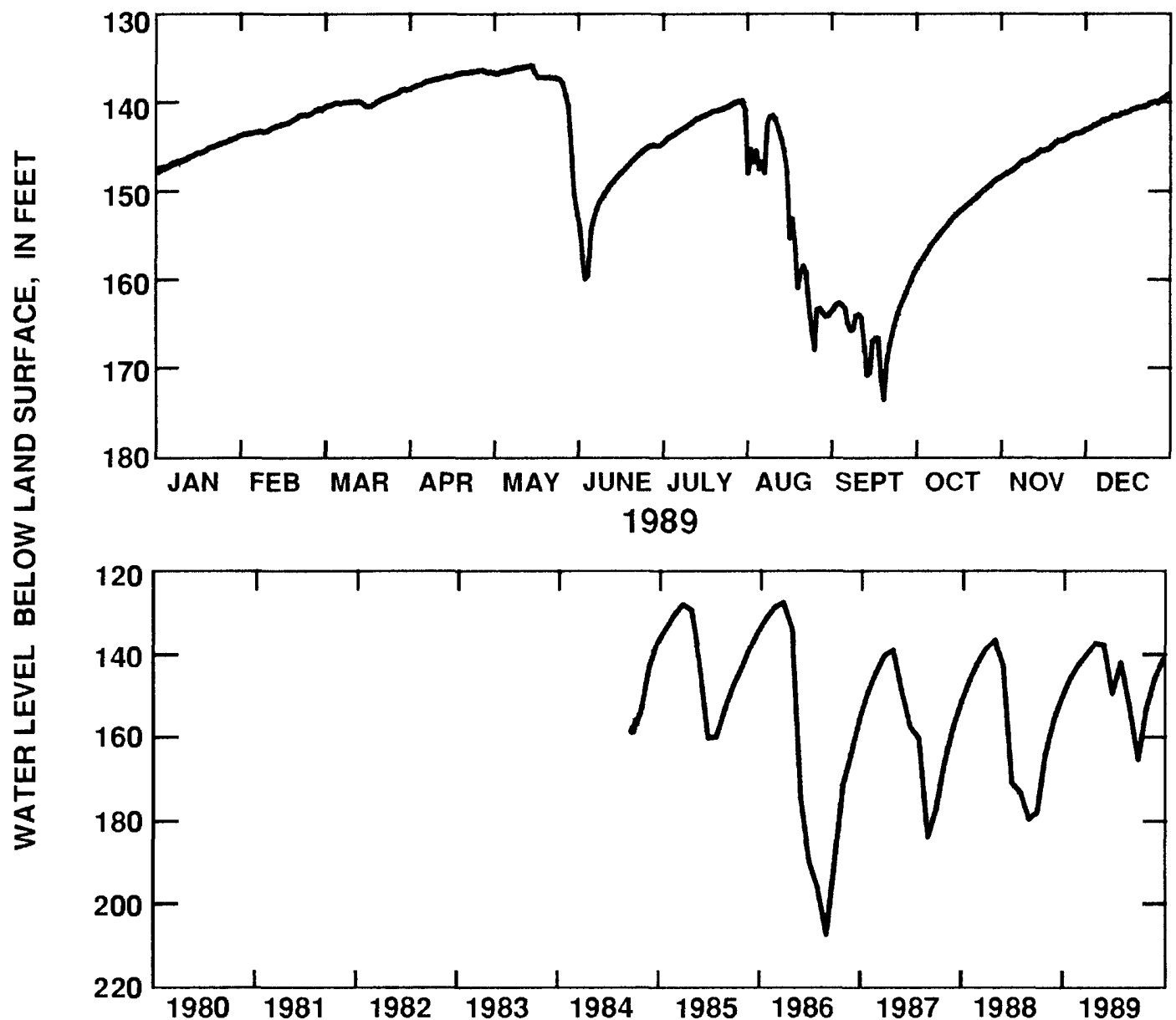

\begin{tabular}{|c|c|c|c|c|c|c|c|c|c|c|c|c|}
\hline 1989 & JAN & FEB & MAR & APR & MAY & JUN & JUL & $A \cup G$ & SEP & OCT & NOV & DEC \\
\hline $\begin{array}{l}\text { IEAN } \\
\text { IAX } \\
\text { IIN }\end{array}$ & $\begin{array}{l}145.69 \\
147.68 \\
143.70\end{array}$ & $\begin{array}{l}142.40 \\
143.58 \\
140.77\end{array}$ & $\begin{array}{l}139.85 \\
140.80 \\
138.51\end{array}$ & $\begin{array}{l}137.19 \\
138.57 \\
136.32\end{array}$ & $\begin{array}{l}137.58 \\
150.32 \\
135.86\end{array}$ & $\begin{array}{l}149.47 \\
159.96 \\
144.78\end{array}$ & $\begin{array}{l}141.88 \\
144.81 \\
139.73\end{array}$ & $\begin{array}{l}152.65 \\
167.97 \\
140.72\end{array}$ & $\begin{array}{l}165.36 \\
173.52 \\
159.93\end{array}$ & $\begin{array}{l}153.06 \\
159.15 \\
148.51\end{array}$ & $\begin{array}{l}145.59 \\
148.37 \\
143.31\end{array}$ & $\begin{array}{l}141.13 \\
143.15 \\
139.23\end{array}$ \\
\hline$A L$ & 1989 & & MEAN & 145.9 & & $\mathrm{HIGH}$ & 135.8 & & LOW & 173.5 & & \\
\hline
\end{tabular}

Figure 78.--Water level in observation well 09M007, Randolph County. 
314611084310301 Local number, 09N001.

LOCATION.--Lat $31^{\circ} 46^{\prime} 09^{\prime \prime}$, long $84^{\circ} 31^{\prime} 07^{\prime \prime}$, Hydrologic Unit $03130009,500 \mathrm{ft}$ south of U.S. Highway 82 behind abandoned school foundations in block house, $1.0 \mathrm{mi}$ west of intersection of U.S. Highway 82 and Ga. Highway 45.

Owner: Terrell County, Graves School.

AQUIFER.--Clayton.

WELL CHARACTERISTICS.--Drilled unused supply well, diameter 6 in., depth $433 \mathrm{ft}$, cased to $333 \mathrm{ft}$, open hole.

DATUM.--Altitude of land-surface datum is $348 \mathrm{ft}$.

Measuring point: Top of $6 \mathrm{in}$. well casing, $0.55 \mathrm{ft}$ below land-surface datum.

REMARKS.--Borehole geophysical survey conducted July 31, 1953. Well pumped and redeveloped August 9, 1989. Water

levels for periods of missing record, January 1-3, and August 9-23, were estimated.

PERIOD OF RECORD.--January 10, 1982 to current year.

EXTREMES FOR PERIOD OF RECORD.--Highest water level, $144.06 \mathrm{ft}$ below land-surface datum, May 16, 1984: lowest,

$241.61 \mathrm{ft}$ below land-surface datum, July $21,1986$.
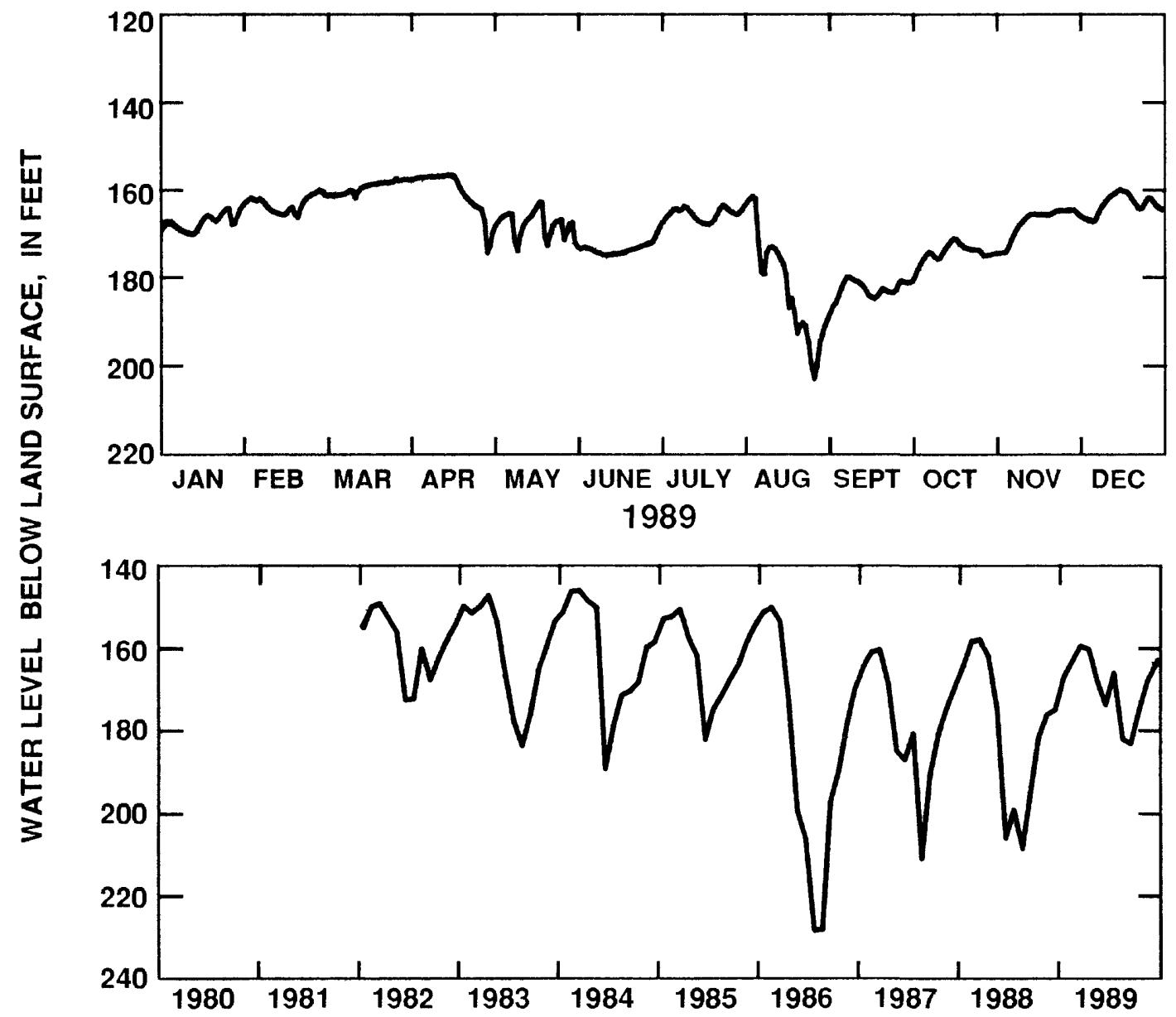

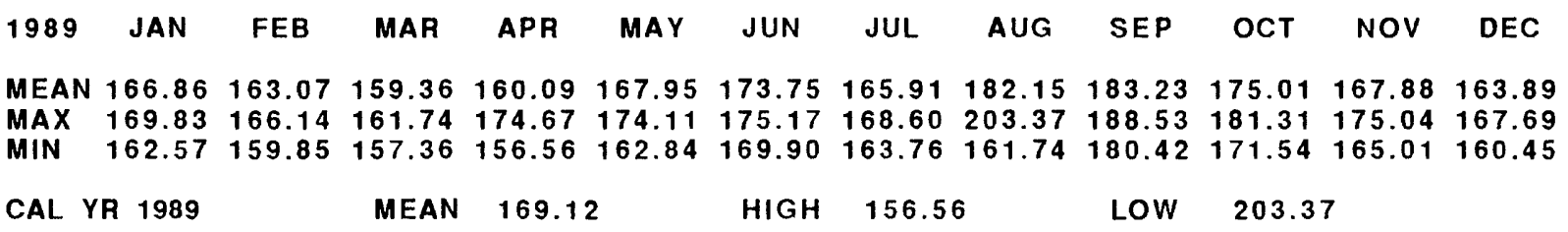

Figure 79.--Water level in observation well 09N001, Terrell County. 
313532084203501 Local number, $11 \mathrm{LOO2}$.

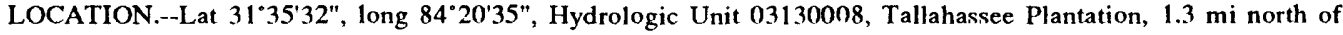
Ga. Highway $234,10.4 \mathrm{mi}$ west of Albany.

Owner: Georgia Geologic Survey, Albany Nursery.

AQUIFER.-Clayton.

WELL CHARACTERISTICS.--Drilled observation well, diameter 3 in., depth $656 \mathrm{ft}$, cased to $542 \mathrm{ft}$, open hole.

DATUM.--Altitude of land-surface datum is $222 \mathrm{ft}$.

Measuring point: Top of recorder shelf, $3.02 \mathrm{ft}$ above land-surface datum.

REMARKS.--Well pumped and redeveloped August 14, 1988. Borehole geophysical survey conducted June 3, 1975.

PERIOD OF RECORD.--September 1973 to current year.

EXTREMES FOR PERIOD OF RECORD.--Highest water level, $58.90 \mathrm{ft}$ helow land-surface datum, April 29, 1975 ; lowest, $152.61 \mathrm{ft}$ below land-surface datum, August 23, 1986.
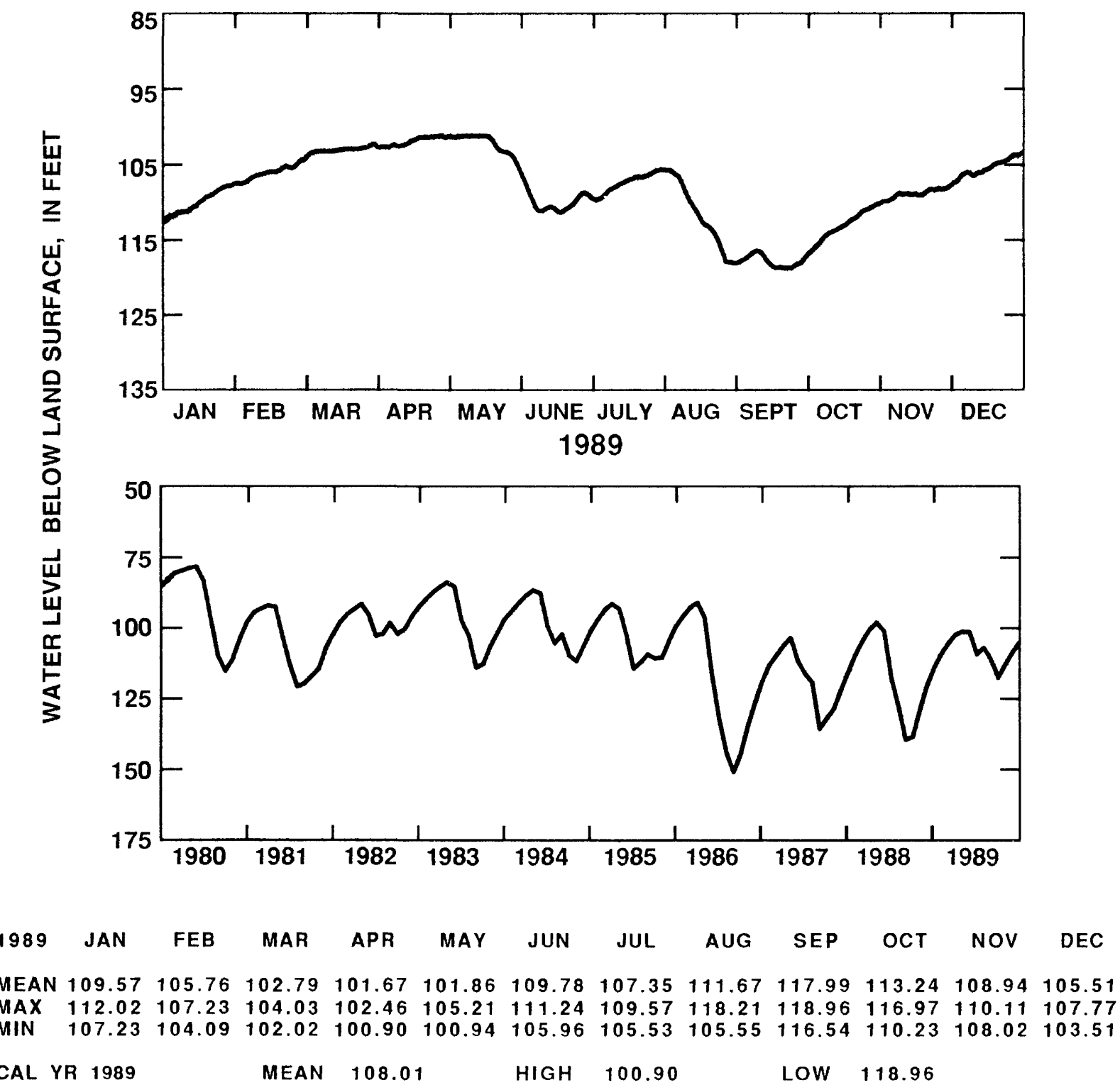

Figure 80.--Water level in observation well 11L002, Dougherty County. 
313554084062501 Local number, $13 \mathrm{~L} 002$.

LOCATION.--Lat $31^{\circ} 35^{\prime} 51^{\prime \prime}$, long $84^{\circ} 06^{\prime} 24^{\prime \prime}$, Hydrologic Unit $03130008,50 \mathrm{ft}$ west of Albany city supply well house,

$75 \mathrm{ft}$ east of church located at the corner of Malone and Gardner Avenue.

Owner: Albany Water, Gas, and Light Commission, Turner City 2.

AQUIFER.--Clayton.

WELL CHARACTERISTICS.--Drilled unused supply well, diameter $12 \mathrm{in}$., depth $760 \mathrm{ft}$, ased to $713 \mathrm{ft}$, open hole.

DATUM.--Altitude of land-surface datum is $212.84 \mathrm{ft}$.

Measuring point: Top of recorder shelf, $3.2 \mathrm{ft}$ above land-surface datum.

REMARKS.--Well pumped and sounded to a depth of $760 \mathrm{ft}$, June 21, 1978; water-quality sample collected at conclusion of pumping. Borehole geophysical survey conducted March 17, 1977. Water levels for periods of missing record,

January 31 to February 20, March 13-21 and 28-30, April 21-27, May 3-5 and 22, and May 30 to June 1, were estimated. PERIOD OF RECORD.--December 1957 to December 1959. January 1962 to current year.

EXTREMES FOR PERIOD OF RECORD.--Highest water leve1, $38.19 \mathrm{ft}$ below land-surface datum, April 1, 1959; lowest,

$160.88 \mathrm{ft}$ below land-surface datum, July $26,1986$.
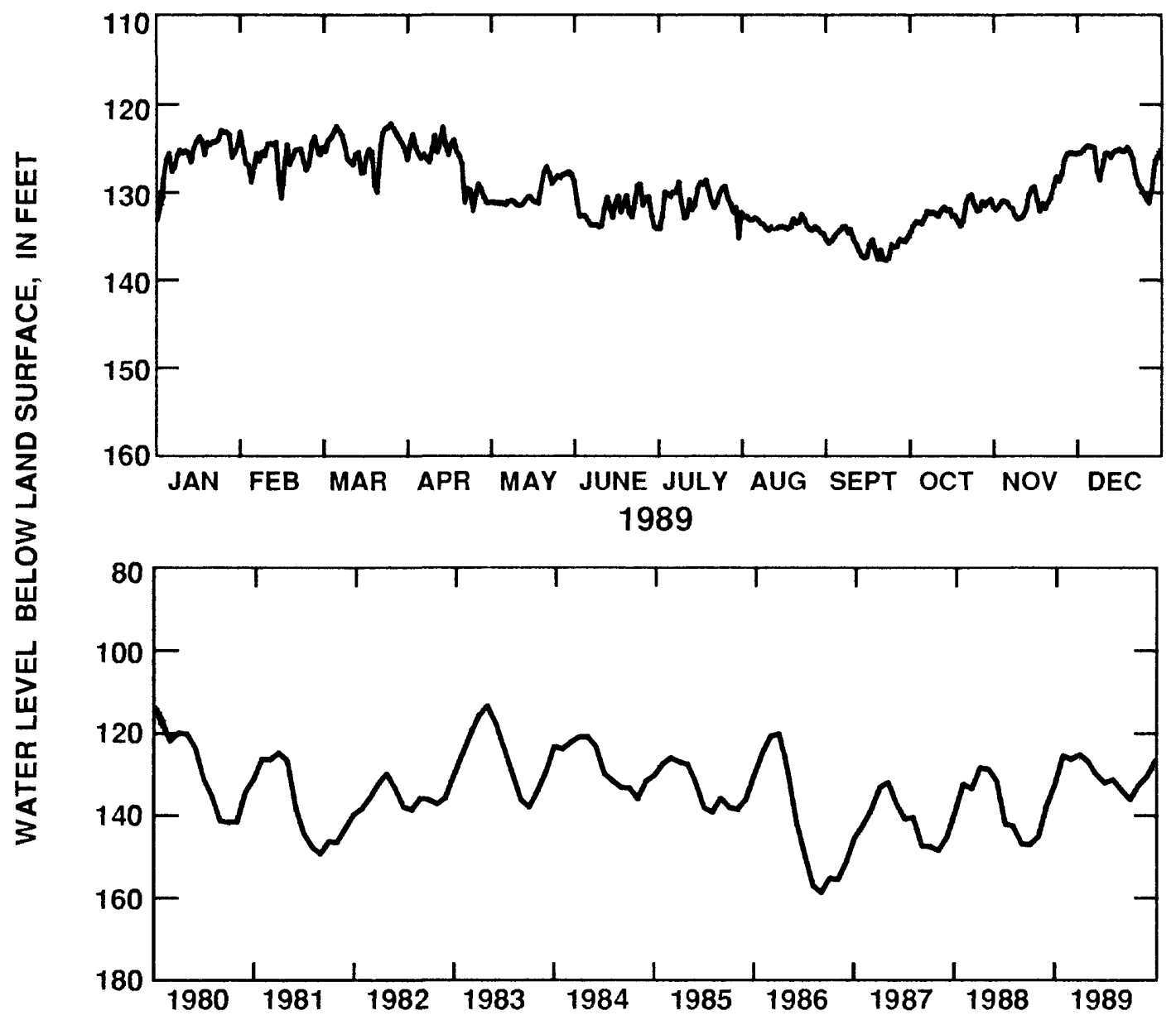

\begin{tabular}{|c|c|c|c|c|c|c|c|c|c|c|c|c|}
\hline 1989 & JAN & FEB & MAR & APR & MAY & JUN & JUL & AUG & SEP & OCT & NOV & DEC \\
\hline $\begin{array}{l}\text { MEAN } \\
\text { MAX } \\
\text { MIN }\end{array}$ & $\begin{array}{l}125.29 \\
130.76 \\
123.05\end{array}$ & $\begin{array}{l}126.15 \\
130.77 \\
123.77\end{array}$ & $\begin{array}{l}125.02 \\
130.07 \\
122.31\end{array}$ & $\begin{array}{l}126.77 \\
132.16 \\
122.69\end{array}$ & $\begin{array}{l}130.06 \\
131.59 \\
127.18\end{array}$ & $\begin{array}{l}131.95 \\
134.03 \\
128.79\end{array}$ & $\begin{array}{l}130.91 \\
134.24 \\
128.73\end{array}$ & $\begin{array}{l}133.73 \\
134.84 \\
132.36\end{array}$ & $\begin{array}{l}135.98 \\
137.81 \\
134.01\end{array}$ & $\begin{array}{l}132.45 \\
135.14 \\
130.36\end{array}$ & $\begin{array}{l}130.38 \\
133.11 \\
125.59\end{array}$ & $\begin{array}{l}126.67 \\
131.27 \\
124.80\end{array}$ \\
\hline AAL Y & R 1989 & & IEAN & 129.62 & & $\mathrm{HIGH}$ & 122.31 & & LOW & 137.81 & & \\
\hline
\end{tabular}

Figure 81.--Water level in observation well 13L002, Dougherty County. 
312827084551501 Local number, 06K009.

LOCATION.--Lat $31^{\circ} 28^{\prime} 24^{\prime \prime}$, long $84^{\circ} 55^{\prime} 12^{\prime \prime}$, Hydrologic Unit 03130004 , westernmost of two recorder wells, 300 yds north of the pool at Kolomoki Mounds State Park, 4.2 mi north of the city limits of Blakely, on Kolomoki Road.

Owner: Georgia Geologic Survey, Kolomoki Mounds State Park test well 1.

AQUIFER.--Clayton.

WELL CHARACTERISTICS.--Drilled observation well, diameter $6 \mathrm{in}$., depth $612 \mathrm{ft}$, cased to $491 \mathrm{ft}$, open hole.

DATUM.--Altitude of land-surface datum is $310 \mathrm{ft}$.

Measuring point: Top of recorder shelf, $3.27 \mathrm{ft}$ above land-surface datum.

REMARK.--Borehole geophysical survey conducted November 20, 1979. Aquifer test conducted May 19, 1982 . Well pumped and redeveloped August 8, 1989.

PERIOD OF RECORD.--August 31, 1984 to current year.

EXTREMES FOR PERIOD OF RECORD.--Highest water level, $146.62 \mathrm{ft}$ below land-surface datum, April 3, 1986; lowest,

$171.38 \mathrm{ft}$ below land-surface datum, August 22, 1986.
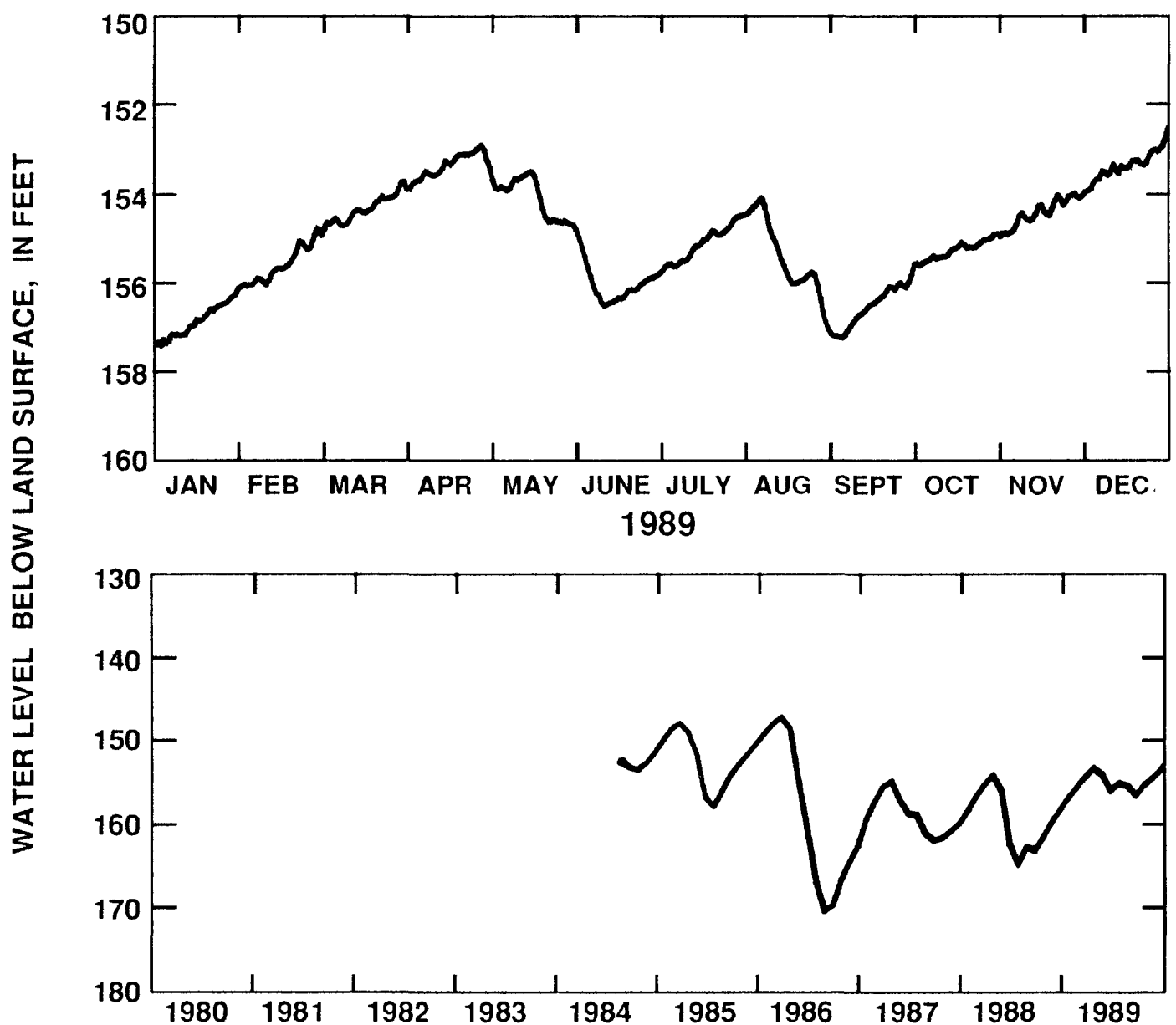

1989 JAN FEB MAR APR MAY JUN JUL AUG SEP OCT NOV DEC

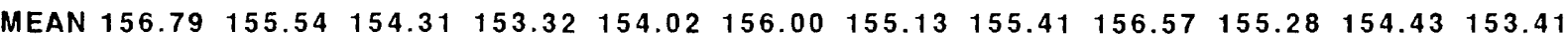

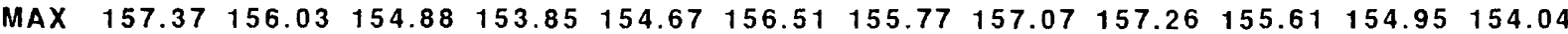

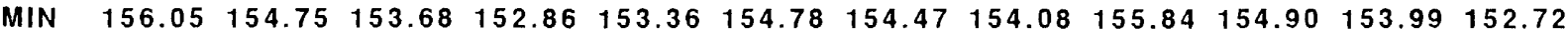

CAL YR 1989

MEAN 155.01

HIGH 152.72

LOW $\quad 157.37$

Figure 82.--Water level in observation well 06K009, Early County. 
312654084210103 Local number, $11 \mathrm{~K} 005$.

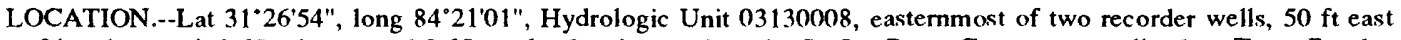
of logging road, $0.65 \mathrm{mi}$ west and 0.65 south of main gate into the St. Joe Paper Company woodland on Tarva Road, $3.6 \mathrm{mi}$ south of Ga. Highway 62 .

Owner: U.S. Geological Survey test well 12.

AQUIFER.--Clayton.

WELL CHARACTERISTICS.--Drilled observation well, diameter 6 in., depth $690 \mathrm{ft}$, cased to $630 \mathrm{ft}$, open hole.

DATUM.--Altitude of land-surface datum is $183 \mathrm{ft}$.

Measuring point: Top of recorder shelf, $3.0 \mathrm{ft}$ above land-surface datum.

REMARKS.--Borehole geophysical survey conducted March 14, 1979.

PERIOD OF RECORD.--May 16, 1979 to current year.

EXTREMES FOR PERIOD OF RECORD.--Highest water leve1, $23.03 \mathrm{ft}$ below land-surface datum, May 24, 1979; lowest, $57.12 \mathrm{ft}$ below land-surface datum, February 9, 1989.

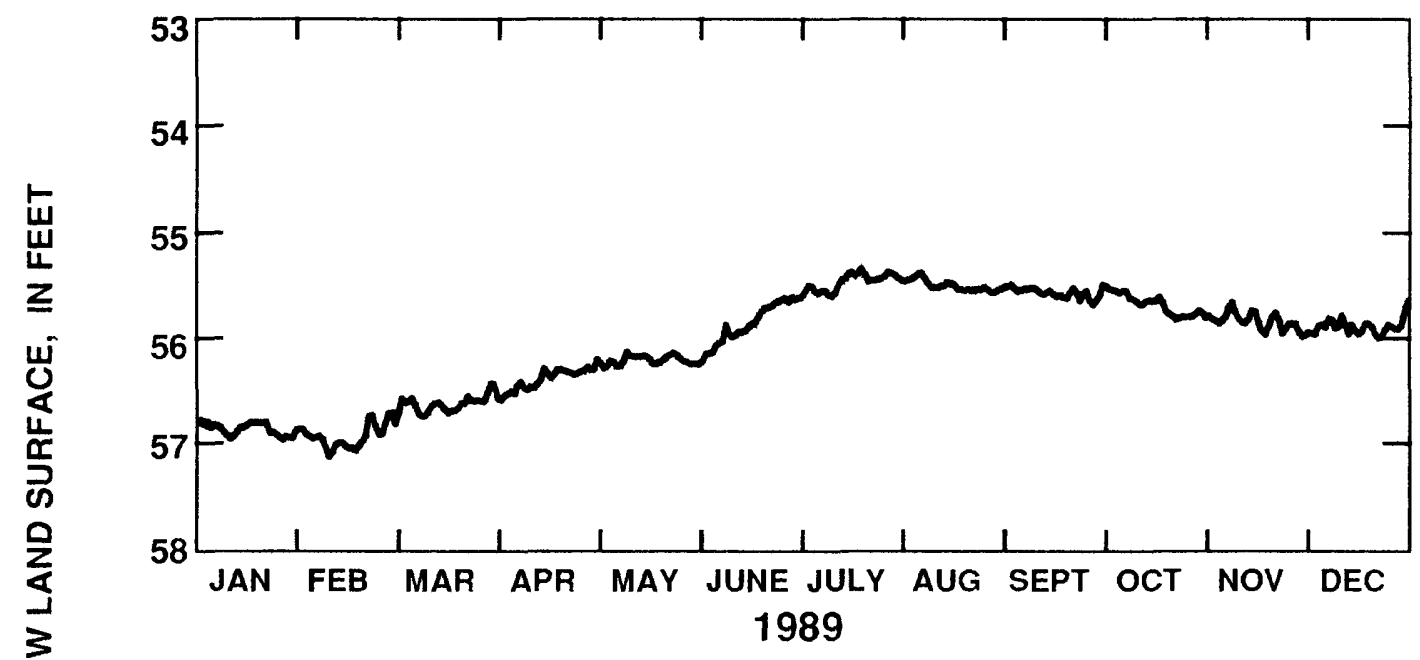

\begin{tabular}{|c|c|c|c|c|c|c|c|c|c|c|c|c|}
\hline 1989 & JAN & FEB & MAR & APR & MAY & JUN & JUL & AUG & SEP & OCT & NOV & DEC \\
\hline $\begin{array}{l}\text { MEAN } \\
\text { MAX } \\
\text { MIN }\end{array}$ & $\begin{array}{l}56.86 \\
56.96 \\
56.79\end{array}$ & $\begin{array}{l}56.93 \\
57.12 \\
56.71\end{array}$ & $\begin{array}{l}56.63 \\
56.81 \\
56.44\end{array}$ & $\begin{array}{l}56.40 \\
56.59 \\
56.28\end{array}$ & $\begin{array}{l}56.21 \\
56.29 \\
56.13\end{array}$ & $\begin{array}{l}55.88 \\
56.25 \\
55.61\end{array}$ & $\begin{array}{l}55.47 \\
55.62 \\
55.34\end{array}$ & $\begin{array}{l}55.50 \\
55.57 \\
55.38\end{array}$ & $\begin{array}{l}55.58 \\
55.69 \\
55.50\end{array}$ & $\begin{array}{l}55.68 \\
55.83 \\
55.50\end{array}$ & $\begin{array}{l}55.85 \\
56.00 \\
55.67\end{array}$ & $\begin{array}{l}55.92 \\
56.02 \\
55.76\end{array}$ \\
\hline CAL YF & 1989 & & MEAN & 56.07 & & $\mathrm{HIGH}$ & 55.34 & & LOW & 57.12 & & \\
\hline
\end{tabular}

Figure 83.--Water level in observation well $11 \mathrm{~K} 005$, Dougherty County. 


\section{Cretaceous Aquifer System}

Water levels in the Cretaceous aquifer system are monitored in nine wells, all of which are included in this report (figs. 84-94). Water levels in the aquifer system are influenced by changes in precipitation, pumping, and natural discharge. During 1985, the aquifer system supphed more than $147 \mathrm{Mgal} / \mathrm{d}$, primarily for municipal and industrial use (Pierce and Kundell, 1990, p. 219).

In Chattahoochee County near Columbus, the water level in wells tapping the Cretaceous aquifer system has shown a long-term water-level decline since 1965. The mean water level in well 06S001 (fig. 85) near Columbus was $1.2 \mathrm{ft}$ lower in 1989 than in 1988 and a record low was measured in December. The water level continued to decline in this area.

\section{Providence aquifer}

The water level in the Providence aquifer in the Albany area is monitored in one well $(12 \mathrm{~L} 021, \mathrm{fig} .86)$ and is affected primarily by changes in local pumping. The aquifer supphed about $9 \mathrm{Mgal} / \mathrm{d}$ for municipal, industrial, and agricultural use in southwestern Georgia during 1980 (Clarke and others, 1983). Pumping from the aquifer has resulted in the development of cones of depression at Albany and Americus and water-level declines near Albany of more than $100 \mathrm{ft}$ during the period 1950-80 (Clarke and others, 1983).

The water-level response to pumping is shown on the hydrograph for well 12L021 at Albany (fig. 86). The mean water level in this well was $4.4 \mathrm{ft}$ higher in 1989 than in 1988. Above-normal precipitation (fig. 8) during 1989 probably resulted in decreased pumping, which allowed the continued recovery of the water level from the 1986 drought.

\section{Dublin, Midville, and Dublin-Midville aquifer systems}

The water levels in the Dublin aquifer system is monitored in one well (18U001, fig. 87) in southern Twiggs County. In this area, water levels in wells tapping the aquifer are affected by precipitation and by pumping in eastern Houston and western Twiggs Counties (Clarke and others, 1985), where pumpage exceeded $37 \mathrm{Mgal} / \mathrm{d}$ in 1985. The mean water level in well $18 \mathrm{U} 001$ (fig. 87) remained about the same in 1989 as in 1988, leveling-off the general downward trend since 1983. Rainfall at Macon (fig. 12) was above normal from April through December 1989, which probably resulted in increased recharge and decreased pumpage, producing a rise in the water level.

The water level in the Midville aquifer system is affected primarily by regional pumping (Clarke and others, 1985) and is monitored in four wells in east-central Georgia. The mean water levels in four wells 18T001, 21U004, 24V001, and 28X001, (figs.88-91) were about the same in 1989 as in 1988, diminishing the downward trend in that area.

During November 1989, water-level measurements were made in 99 wells tapping the Dublin-Midville aquifer system. These measurements were used to prepare a water-level map (fig. 92). Since the last map was constructed in October 1984 (Clarke and others, 1986, p. 33), the configuration of the water-level map changed at Sandersville and Deepstep, Washington County. In these areas, the size of existing cones of depression increased slightly, possibly indicating that pumping had increased during 1984-89.

The water level in the Dublin-Midville aquifer system is monitored continuously in two wells, one in Richmond County (30AA04, fig. 93) and one at Sandersville, Washington County (23X027, fig. 94). The water level in wells tapping the Dublin-Midville aquifer system in Richmond County is influenced primarily by precipitation and by local pumping (Gorday, 1985, p. 28). (See hydrograph for well 30AA04 (fig. 93) near McBean.) The mean water level in well 30AA04 was $0.6 \mathrm{ft}$ higher in 1989 than in 1988 as a result of abovenormal precipitation and possibly decreased pumping during the year. (See precipitation graph for Augusta, figure 10.) This rise reversed the downward trend in water-levels that began in 1985. 
$35^{\circ}=-$

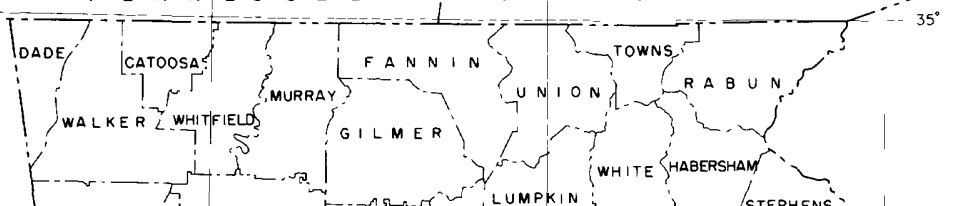

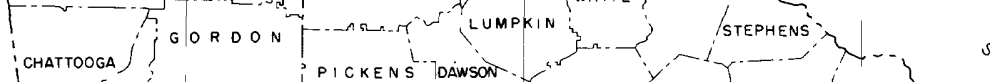

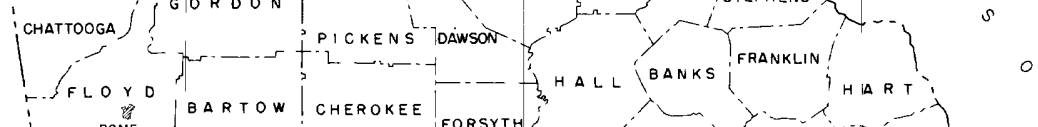

AREA IN WHICH CRETACEOUS AQUIFER SYSTEM IS UTILIZED

OBSERVATION WELL AND IDENTIFICATION NUMBER--Equipped with recorder; hydrograph included in this report

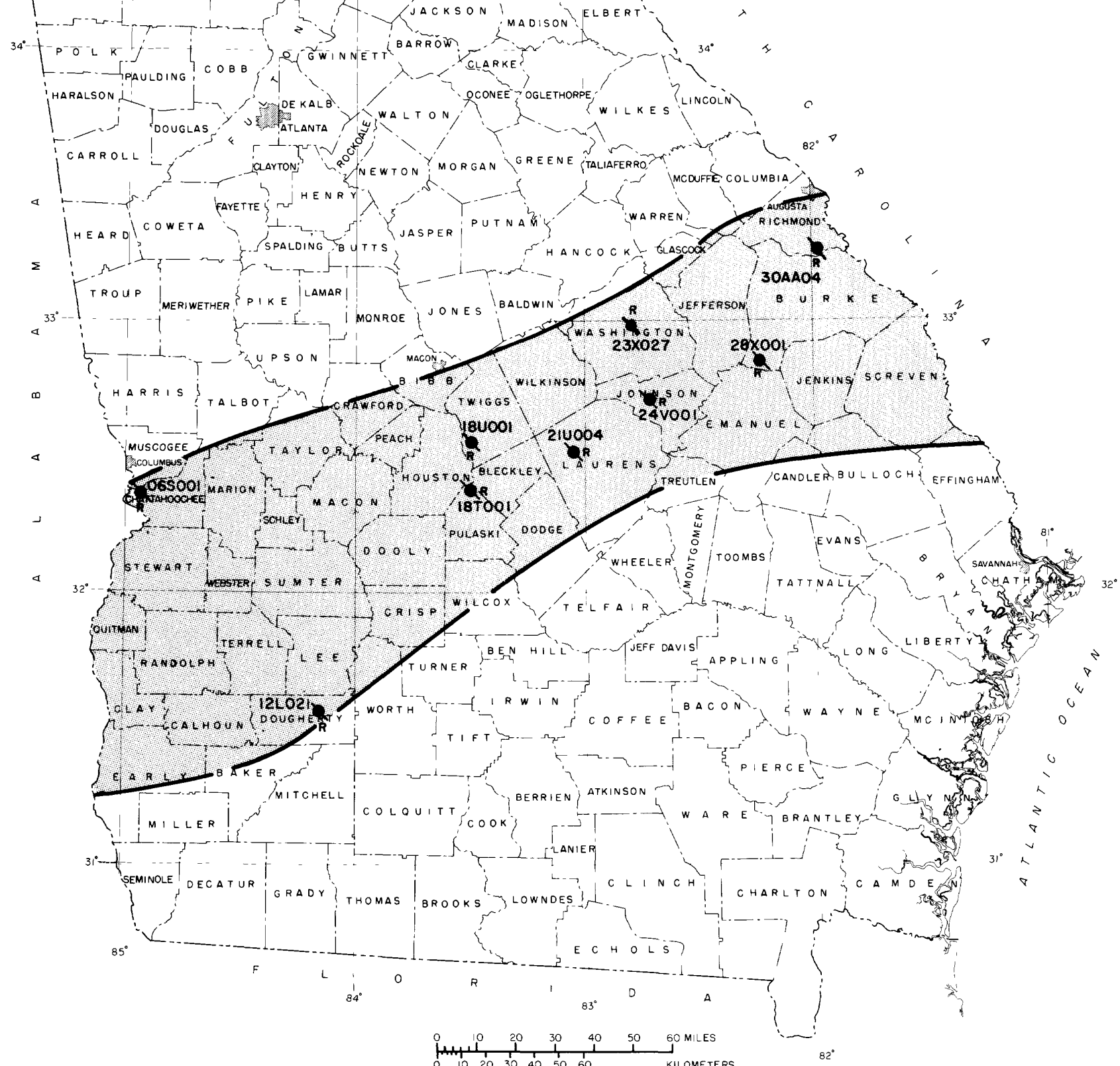

Figure 84.--Locations of observation wells completed in the Cretaceous aquifer system. 
322036084590301 Local number, 06S001

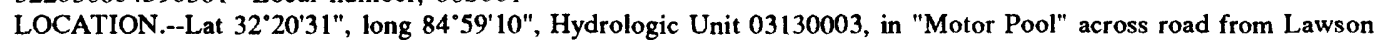

Airfield main building.

Owner: U.S. Army, Fort Benning.

AQUIFER.-- Cretaceous (Blufftown, Eutaw, and Tuscaloosa Formations).

WELL CHARACTERISTICS.--Drilled unused supply well, diameter 12 in., depth $568 \mathrm{ft}$, screened intervals $215-220 \mathrm{ft}$, 230-235 ft, 280-290 ft, and 540-550 ft.

DATUM.--Altitude of land-surface datum is $255 \mathrm{ft}$.

Measuring point: Top of recorder shelf, $2.80 \mathrm{ft}$ above land-surface datum.

REMARKS.--Well pumped and redeveloped August 7, 1989. Well pumped and sampled by Georgia Geologic Survey

November 29-30, 1989. Water levels for period of missing record, November 29 to December 8 , were estimated.

PERIOD OF RECORD.--May 1950 to current year.

EXTREMES FOR PERIOD OF RECORD.--Highest water level, $0.37 \mathrm{ft}$ below land-surface datum, April 10, 1964; lowest,

$31.18 \mathrm{ft}$ below land-surface datum, December 30, 1989.

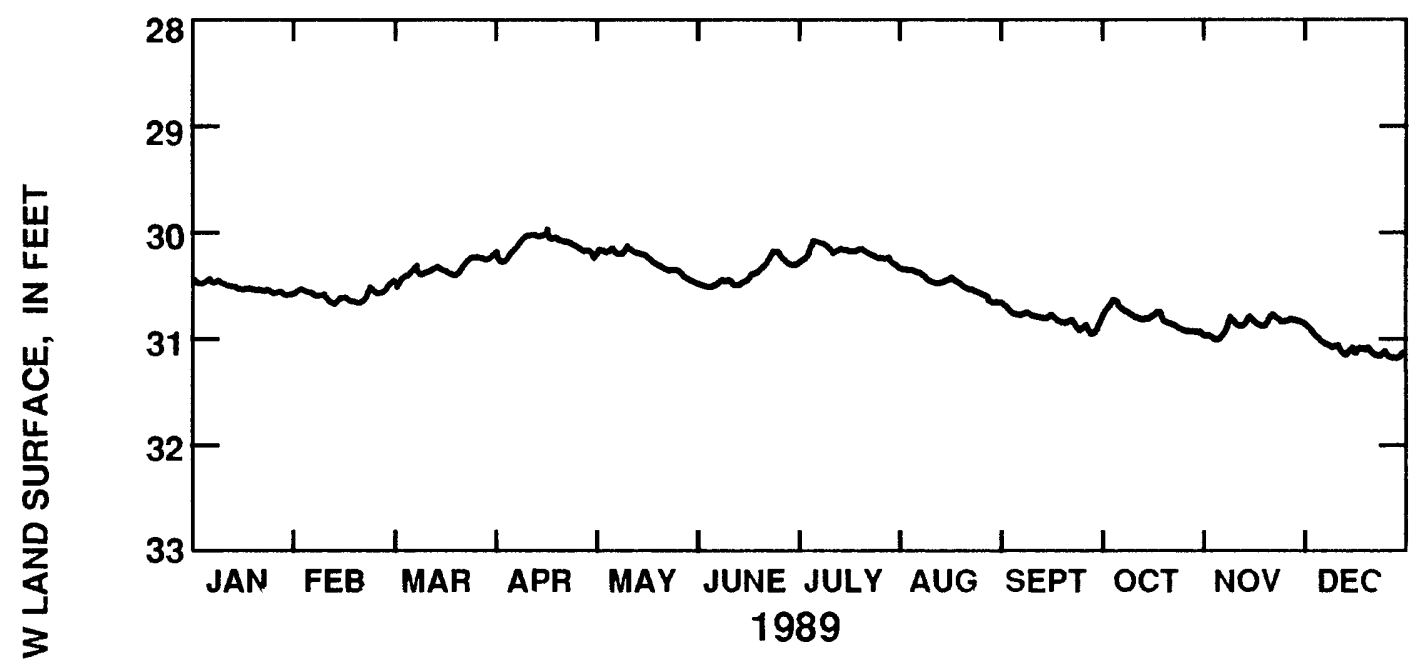

塀

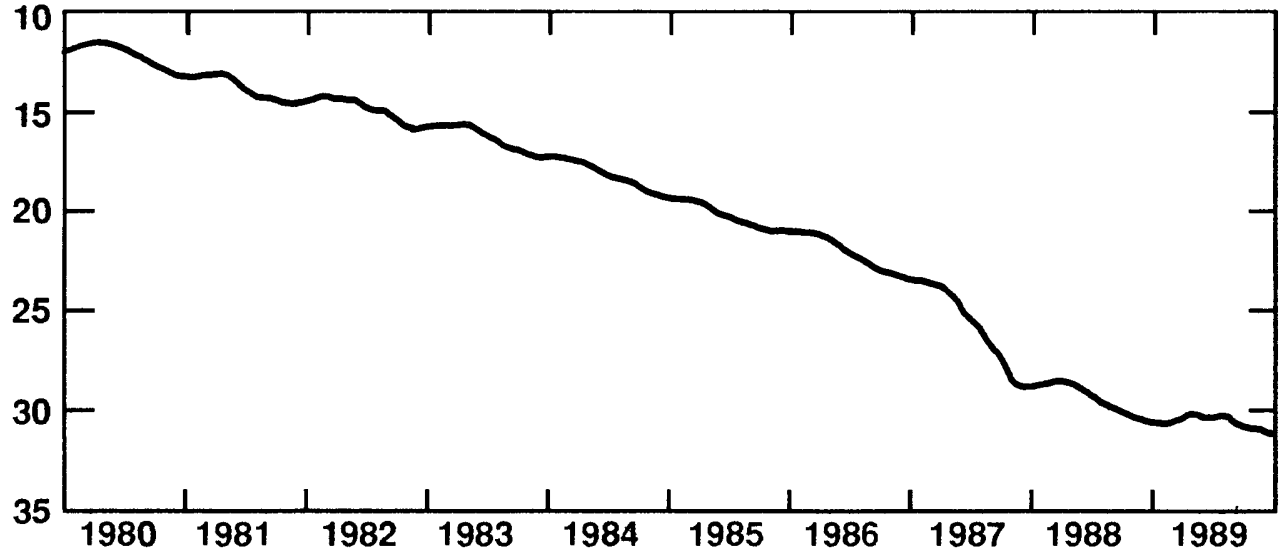

$\begin{array}{lllllllllllll}1989 & \text { JAN } & \text { FEB } & \text { MAR } & \text { APR } & \text { MAY } & \text { JUN } & \text { JUL } & \text { AUG } & \text { SEP } & \text { OCT } & \text { NOV } & \text { DEC } \\ & & & & & & & & & & & & \\ \text { MEAN } & 30.52 & 30.58 & \mathbf{3 0 . 3 3} & \mathbf{3 0 . 1 1} & \mathbf{3 0 . 2 7} & \mathbf{3 0 . 3 8} & \mathbf{3 0 . 1 9} & \mathbf{3 0 . 4 9} & \mathbf{3 0 . 8 2} & \mathbf{3 0 . 8 1} & \mathbf{3 0 . 8 7} & 31.08 \\ \text { MAX } & \mathbf{3 0 . 5 8} & \mathbf{3 0 . 6 7} & \mathbf{3 0 . 5 1} & \mathbf{3 0 . 2 8} & \mathbf{3 0 . 4 8} & \mathbf{3 0 . 5 2} & \mathbf{3 0 . 3 1} & \mathbf{3 0 . 6 7} & \mathbf{3 0 . 9 5} & \mathbf{3 0 . 9 4} & \mathbf{3 1 . 0 2} & 31.18 \\ \text { MIN } & \mathbf{3 0 . 4 3} & \mathbf{3 0 . 4 5} & \mathbf{3 0 . 1 8} & \mathbf{2 9 . 9 8} & \mathbf{3 0 . 1 4} & \mathbf{3 0 . 1 6} & \mathbf{3 0 . 0 7} & \mathbf{3 0 . 3 4} & \mathbf{3 0 . 6 8} & \mathbf{3 0 . 6 2} & \mathbf{3 0 . 7 7} & \mathbf{3 0 . 8 8} \\ & & & & & & & & & & & & \end{array}$

Figure 85.--Water level in observation well 065001, Chattahoochee County. 
313534084103003 Local number, 12 L021.

LOCATION.--Lat $31^{\circ} 35^{\prime} 37^{\prime \prime}$, long $84^{\circ} 10^{\prime} 29^{\prime \prime}$, Hydrologic Unit 03130008 , located in park at intersection of Slappey

Drive and Fifth Avenue.

Owner: U.S. Geological Survey test well 10.

AQUIFER.--Providence

WELL CHARACTERISTICS.--Drilled observation well, diameter 6 in., depth $834 \mathrm{ft}$, cased to $810 \mathrm{ft}$, screen to $830 \mathrm{ft}$. DATUM.--Altitude of land-surface datum is $198 \mathrm{ft}$.

Measuring point: Top of recorder shelf, $3.0 \mathrm{ft}$ above land-surface datum.

REMARKS.--Borehole geophysical survey conducted October 26, 1978. Well pumped and sampled October $24,1989$.

PERIOD OF RECORD.--December 1978 to current year.

EXTREMES FOR PERIOD OF RECORD.--Highest water level, $101.59 \mathrm{ft}$ below land-surface datum, Apri1 26, $1984:$ lowest,

$156.36 \mathrm{ft}$ below land-surface datum, July $26,1986$.
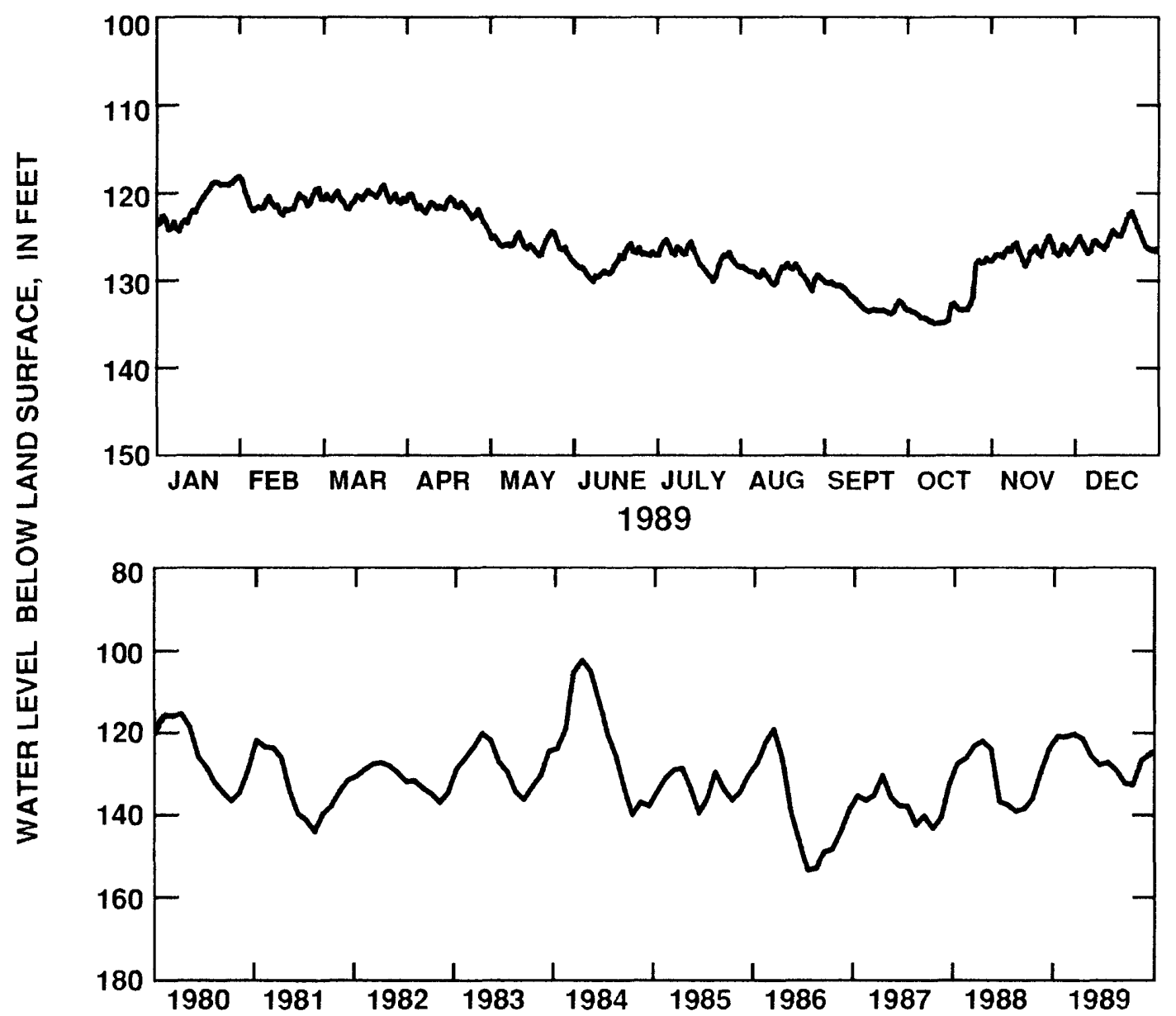

1989 JAN FEB MAR APR MAY JUN JUL AUG SEP OCT NOV DEC

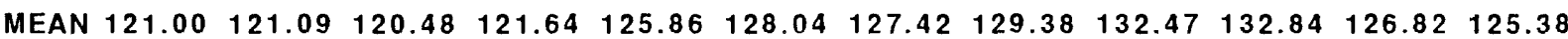

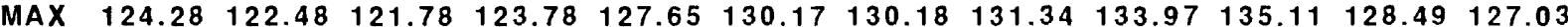

MIN $\quad 118.07 \quad 119.44 \quad 119.09 \quad 120.16 \quad 124.35 \quad 125.83 \quad 125.39 \quad 128.16 \quad 130.33 \quad 127.59 \quad 125.01 \quad 122.30$

CAL YR 1989

MEAN 126.06

HIGH $\quad 118.07$

LOW $\quad 135.11$

Figure 86.--Water level in observation well 12L021, Dougherty County. 
323302083263401 Local number, $18 \mathrm{U} 001$.

LOCATION.--Lat $32^{\circ} 33^{\circ} 02^{\prime \prime}$, long $83^{\circ} 26^{\prime} 34^{\prime \prime}$, Hydrologic Unit $03070104,0.6$ mi north of intersection of U.S. Highways

23 and 12 and Ga. Highway 96, 100 feet west of highway near Woods Road West.

Owner: Georgia Kraft, U.S. Geological Survey test well 3.

AQUIFER.--Dublin aquifer system.

WELL CHARACTERISTICS.--Drilled observation well, diameter $6 \mathrm{in}$., depth $616 \mathrm{ft}$ cased to $586 \mathrm{ft}$, screen to $616 \mathrm{ft}$.

DATUM.--Altitude of land-surface datum is $442 \mathrm{ft}$.

Measuring point: Top of recorder shelf, $2.6 \mathrm{ft}$ above land-surface datum.

REMARKS.--Water-quality analysis June 10, 1975.

PERIOD OF RECORD.--July 1975 to current year.

EXTREMES FOR PERIOD OF RECORD.--Highest water level, $162.0 \mathrm{ft}$ below land-surface datum, April 4, 1977: lowest, $166.39 \mathrm{ft}$ below land-surface datum, August 10-11, 1986.
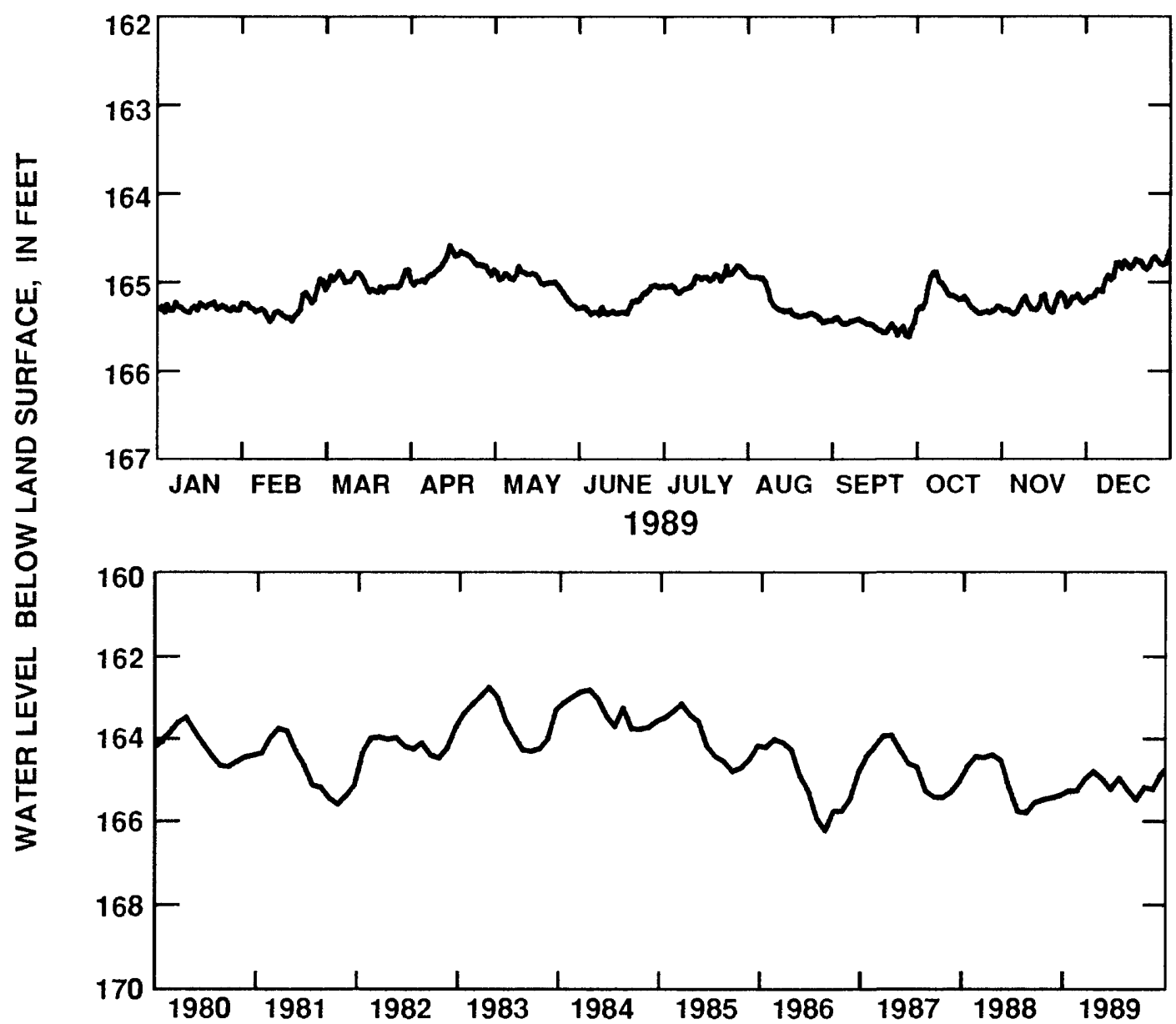

\begin{tabular}{|c|c|c|c|c|c|c|c|c|c|c|c|c|}
\hline 1989 & JAN & FEB & MAR & APR & MAY & JUN & JUL & AUG & SEP & OCT & NOV & DEC \\
\hline $\begin{array}{l}\text { MEAN } \\
\text { MAX } \\
\text { MIN }\end{array}$ & $\begin{array}{l}165.29 \\
165.35 \\
165.23\end{array}$ & $\begin{array}{l}165.29 \\
165.45 \\
164.97\end{array}$ & $\begin{array}{l}165.01 \\
165.12 \\
164.87\end{array}$ & $\begin{array}{l}164.83 \\
165.04 \\
164.59\end{array}$ & $\begin{array}{l}165.01 \\
165.31 \\
164.83\end{array}$ & $\begin{array}{l}165.27 \\
165.38 \\
165.05\end{array}$ & $\begin{array}{l}164.99 \\
165.14 \\
164.83\end{array}$ & $\begin{array}{l}165.28 \\
165.48 \\
164.95\end{array}$ & $\begin{array}{l}165.52 \\
165.65 \\
165.42\end{array}$ & $\begin{array}{l}165.22 \\
165.38 \\
164.91\end{array}$ & $\begin{array}{l}165.28 \\
165.39 \\
165.15\end{array}$ & $\begin{array}{l}164.91 \\
165.24 \\
164.71\end{array}$ \\
\hline SAL & R 1989 & & MEAN & 165.1 & & $\mathrm{HIGH}$ & 164.5 & & LOW & 165.6 & & \\
\hline
\end{tabular}

Figure 87.--Water level in observation well 18U001, Twiggs County. 
322245083290101 Local number, $18 \mathrm{~T} 001$.

LOCATION.--Lat $32^{\circ} 22^{\prime} 45^{\prime \prime}$, long $83^{\circ} 29^{\prime} 01^{\prime \prime}$, Hydrologic Unit 03070104 , about 8.5 mi west of Cochran off Ga. Highway 126, at Georgia Forestry Commission Tree Nursery.

Owner: U.S. Geological Survey, Arrowhead test well 1.

AQUIFER.--Midville aquifer system.

WELL CHARACTERISTICS.--Drilled observation well, diameter 6 in., depth $1,555 \mathrm{ft}$, cased to $970 \mathrm{ft}$, screened intervals, $970-980 \mathrm{ft}, 1,110-1,130 \mathrm{ft}$, and $1,270-1,280 \mathrm{ft}$.

DATUM.--Altitude of land-surface datum is $334 \mathrm{ft}$.

Measuring point: Top of recorder shelf, $3.0 \mathrm{ft}$ above land-surface datum.

REMARKS.--Borehole geophysical survey conducted January 28 and April 15, 1981. Water-quality analysis May 12 , 1981.

PERIOD OF RECORD.--June 1981 to current year.

EXTREMES FOR PERIOD OF RECORD.--Highest water level, $55.48 \mathrm{ft}$ below land-surface datum, April 12, 1983: lowest,

$59.41 \mathrm{ft}$ below land-surface datum, August 22, 1986.
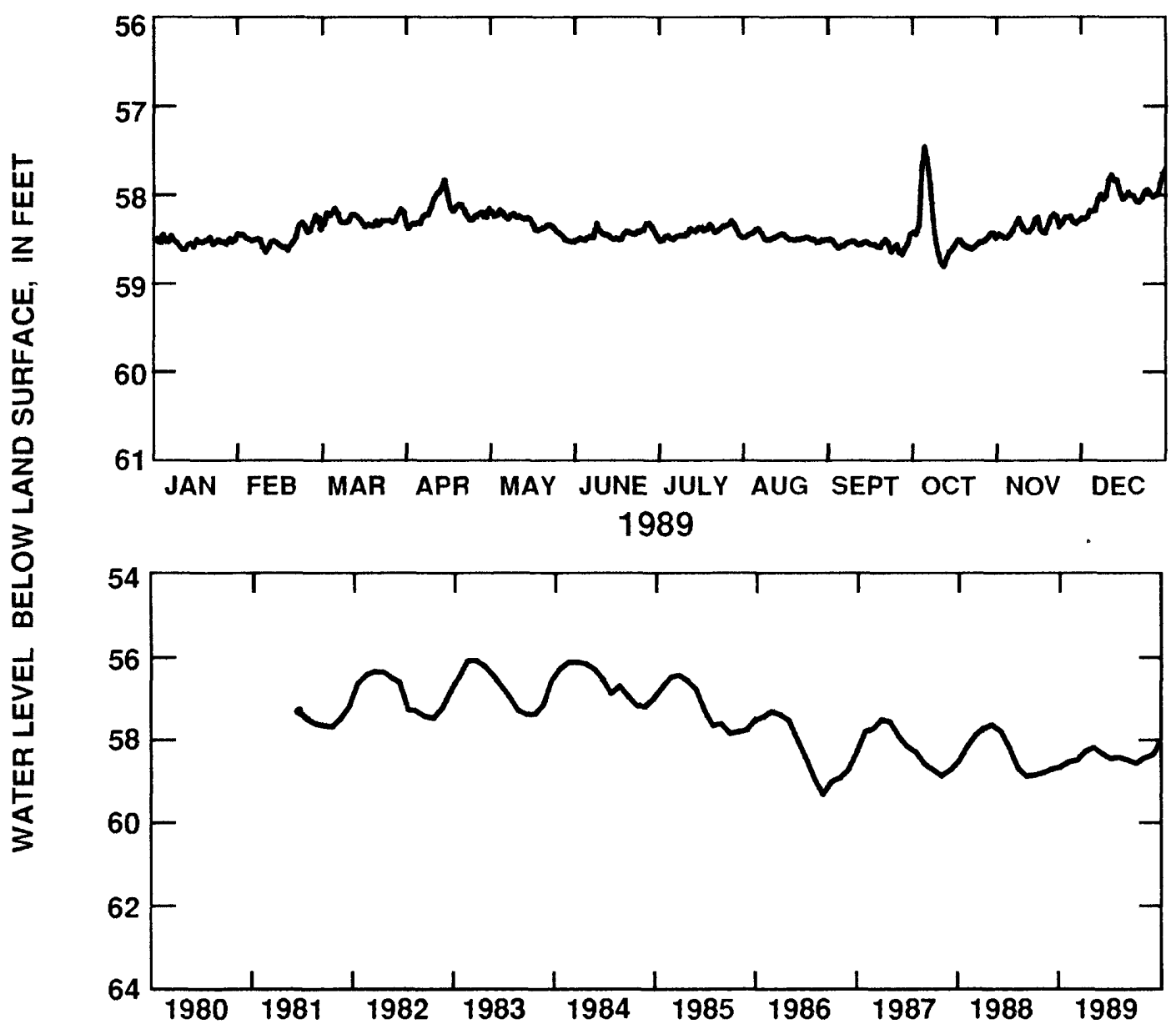

\begin{tabular}{|c|c|c|c|c|c|c|c|c|c|c|c|c|}
\hline 1989 & JAN & FEB & MAR & APR & MAY & JUN & JUL & $A \cup G$ & SEP & $\mathrm{OCT}$ & NOV & DEC \\
\hline $\begin{array}{l}\text { MEAN } \\
\text { MAX } \\
\text { MIN }\end{array}$ & $\begin{array}{l}58.54 \\
58.63 \\
58.45\end{array}$ & $\begin{array}{l}58.49 \\
58.66 \\
58.24\end{array}$ & $\begin{array}{l}58.29 \\
58.40 \\
58.16\end{array}$ & $\begin{array}{l}58.19 \\
58.39 \\
57.84\end{array}$ & $\begin{array}{l}58.33 \\
58.54 \\
58.17\end{array}$ & $\begin{array}{l}58.45 \\
58.54 \\
58.33\end{array}$ & $\begin{array}{l}58.42 \\
58.53 \\
58.30\end{array}$ & $\begin{array}{l}58.49 \\
58.54 \\
58.39\end{array}$ & $\begin{array}{l}58.57 \\
58.68 \\
58.51\end{array}$ & $\begin{array}{l}58.44 \\
58.82 \\
57.46\end{array}$ & $\begin{array}{l}58.36 \\
58.49 \\
58.23\end{array}$ & $\begin{array}{l}58.04 \\
58.30 \\
57.78\end{array}$ \\
\hline AL $Y$ & 1989 & & MEAN & 58.38 & & HIGH & 57.46 & & LOW & 58.82 & & \\
\hline
\end{tabular}

Figure 88.--Water level in observation well 18T001, Pulaski County. 
323030083030003 Local number, $21 \mathrm{U} 004$.

LOCATION.--Lat $32^{\circ} 30^{\prime} 27^{\prime \prime}$, long $83^{\circ} 02^{\prime} 44^{\prime \prime}$, Hydrologic Unit 03070102 , at rest area No. 87 on Interstate 16

east between mile posts 43 and 44 .

Owner: U.S. Geological Survey, Laurens 3.

AQUIFER.--Midville aquifer system.

WELL CHARACTERISTICS.--Drilled observation well, diameter $6 \mathrm{in}$., depth 1,68.5 $\mathrm{ft}$, cased to $1,060 \mathrm{ft}$, screened intervals, 1,060-1,080 ft, and 1,220-1,240 ft.

DATUM.--Altitude of land-surface datum is $282 \mathrm{ft}$.

Measuring point: Top of recorder shelf, $3.0 \mathrm{ft}$ above land-surface datum.

REMARKS.--Borehole geophysical survey conducted December 4, 1981. Water-quality analysis January $28,1982$. Water

levels for periods of missing record, January 1-19, and February 9 to March 7, were estimated.

PERIOD OF RECORD.--February 1982 to current year.

EXTREMES FOR PERIOD OF RECORD.--Highest water level, $35.17 \mathrm{ft}$ below land-surface datum, April 3, 1983; lowest,

$38.85 \mathrm{ft}$ below land-surface datum, December $2,1988$.

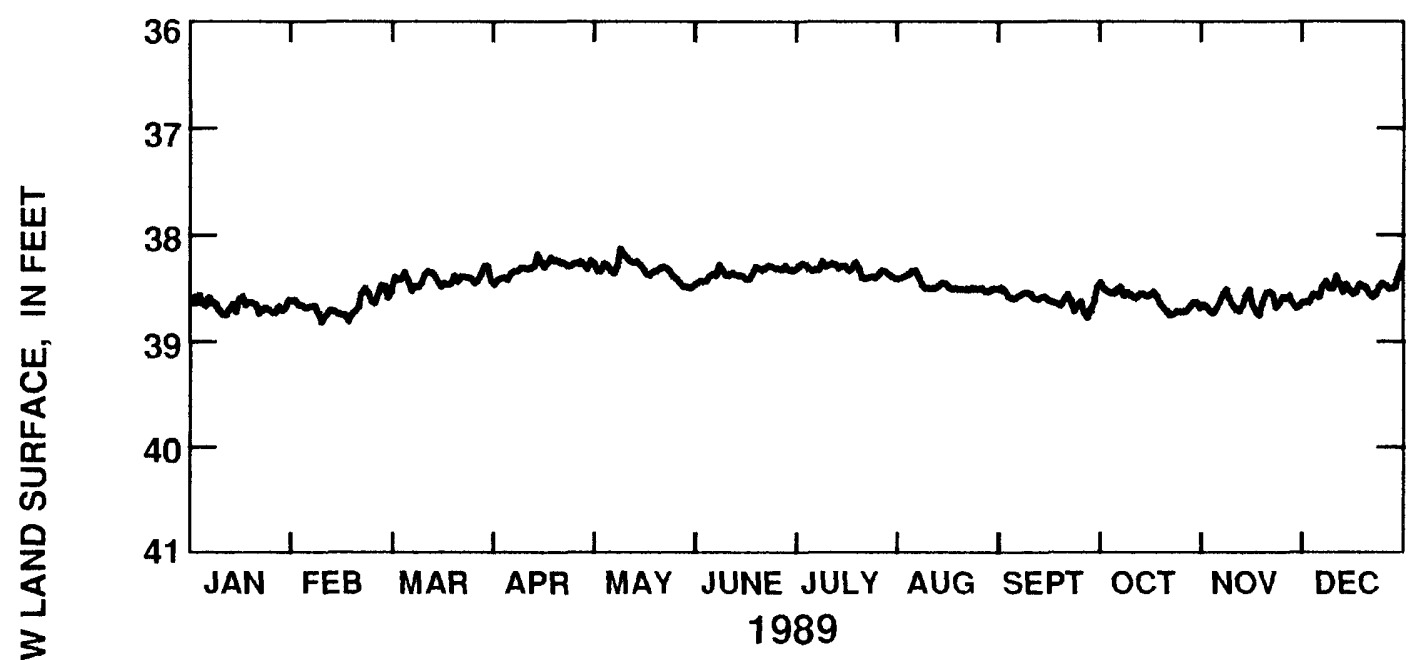

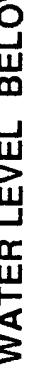

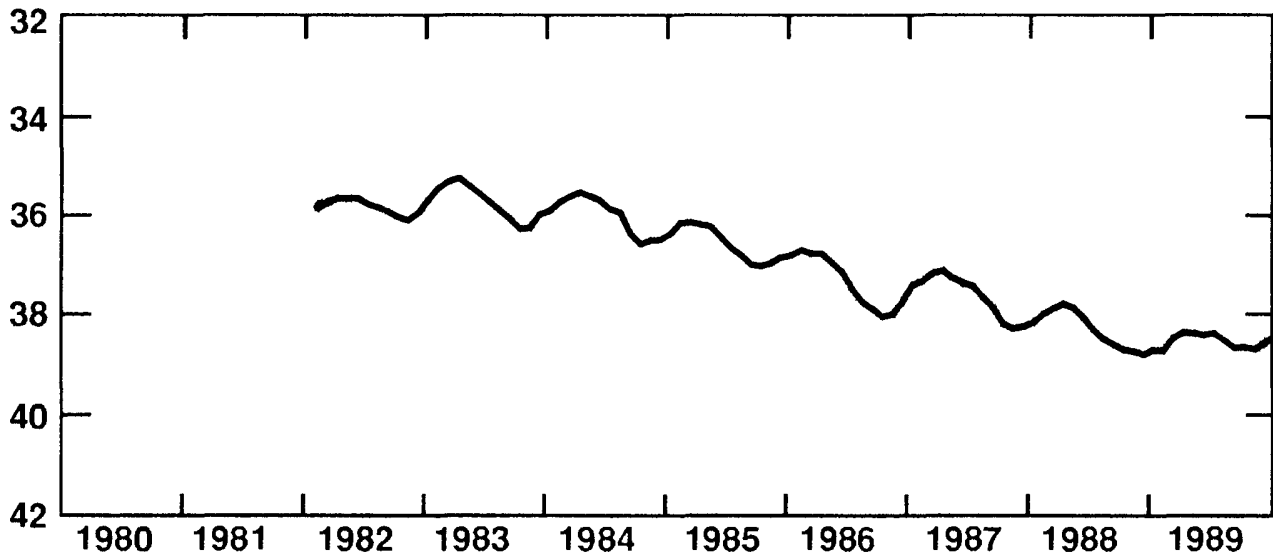

\begin{tabular}{|c|c|c|c|c|c|c|c|c|c|c|c|c|}
\hline 1989 & JAN & FEB & MAR & APR & MAY & JUN & JUL & AUG & SEP & OCT & NOV & DEC \\
\hline $\begin{array}{l}\text { MEAN } \\
\text { MAX } \\
\text { MIN }\end{array}$ & $\begin{array}{l}38.67 \\
38.76 \\
38.58\end{array}$ & $\begin{array}{l}38.68 \\
38.83 \\
38.48\end{array}$ & $\begin{array}{l}38.43 \\
38.60 \\
38.30\end{array}$ & $\begin{array}{l}38.32 \\
38.48 \\
38.19\end{array}$ & $\begin{array}{l}38.33 \\
38.51 \\
38.14\end{array}$ & $\begin{array}{l}38.38 \\
38.50 \\
38.29\end{array}$ & $\begin{array}{l}38.34 \\
38.43 \\
38.26\end{array}$ & $\begin{array}{l}38.49 \\
38.55 \\
38.35\end{array}$ & $\begin{array}{l}38.63 \\
38.80 \\
38.52\end{array}$ & $\begin{array}{l}38.63 \\
38.78 \\
38.47\end{array}$ & $\begin{array}{l}38.66 \\
38.78 \\
38.54\end{array}$ & $\begin{array}{l}38.54 \\
38.70 \\
38.38\end{array}$ \\
\hline CAL YI & 1989 & & MEAN & 38.51 & & HIGH & 38.14 & & LOW & 38.83 & & \\
\hline
\end{tabular}

Figure 89.--Water level in observation well 21U004, Laurens County. 
324209082430201 Local number, $24 \mathrm{~V} 001$.

LOCATION.--lat $32^{\circ} 42^{\prime} 09^{\prime \prime}$, long $82^{\circ} 43^{\prime} 02^{\prime \prime}$, Hydrologic Unit 03070107 , about $500 \mathrm{ft}$ west of Ga. Highway $15,1.8 \mathrm{mi}$ south of intersection of Ga. Highways 15 and 57, at Georgia Forestry Commission Firetower.

Owner: U.S. Geological Survey test well 1.

AQUIFER.--Midville aquifer system.

WELL CHARACTERISTICS.--Drilled observation well, diameter 6 in., depth $1,780 \mathrm{ft}$, cased to $1,120 \mathrm{ft}$, screened intervals, $1,120-1,140 \mathrm{ft}, 1,260-1,280 \mathrm{ft}$, and $1,320-1,340 \mathrm{ft}$.

DATUM.--Altitude of land-surface datum is $355 \mathrm{ft}$.

Measuring point: Top of recorder shelf, $3.0 \mathrm{ft}$ above land-surface datum.

REMARKS.--Borehole geophysical survey conducted July 15 and August 18, 1980 . Water-quality analysis August 29 , 1980.

PERIOD OF RECORD.--September 1980 to current year.

EXTREMES FOR PERIOD OF RECORD.--Highest water level. $129.30 \mathrm{ft}$ below land-surface datum, March 5, 1981; lowest, $136.52 \mathrm{ft}$ below land-surface datum, December 2, 1988.
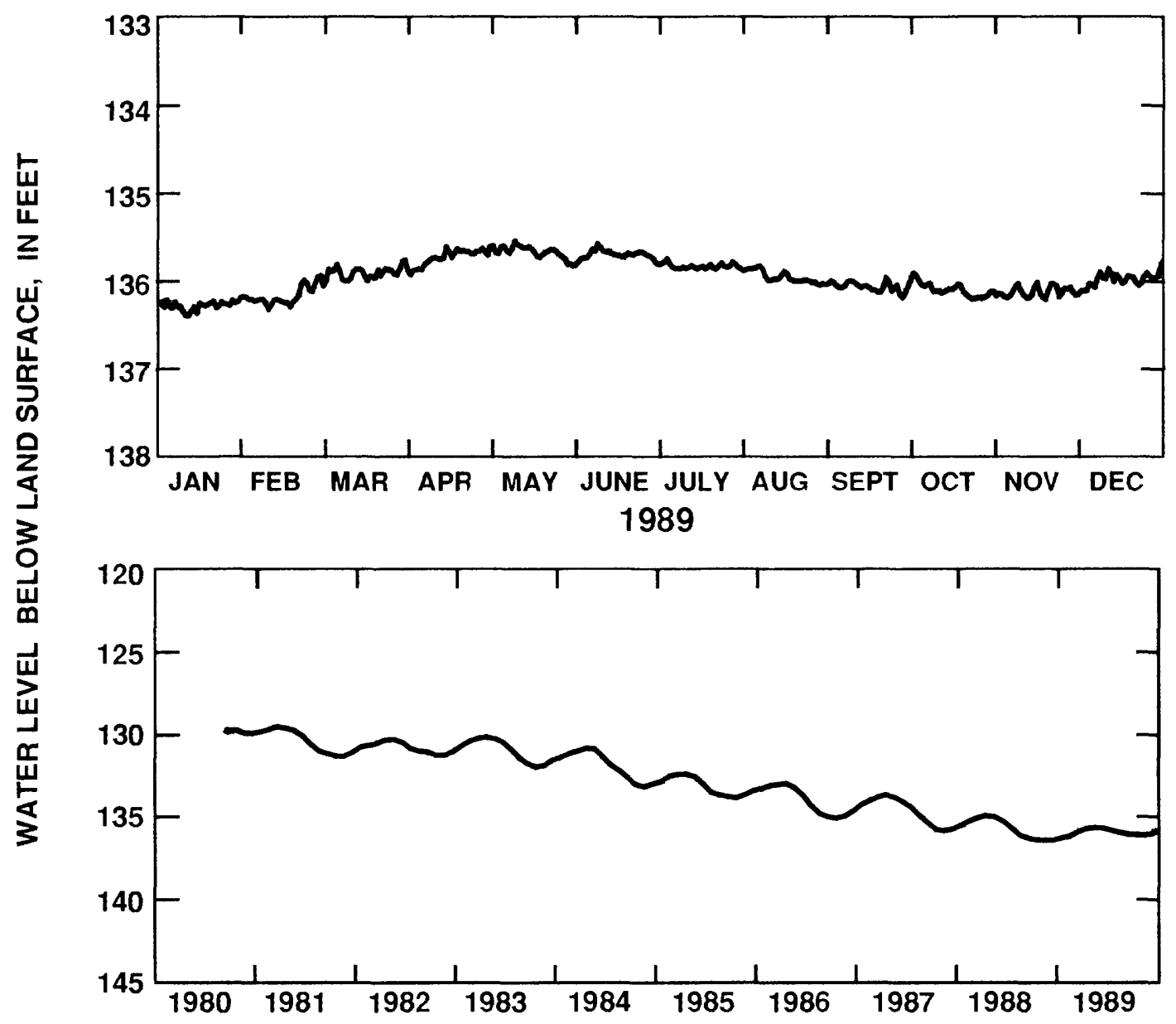

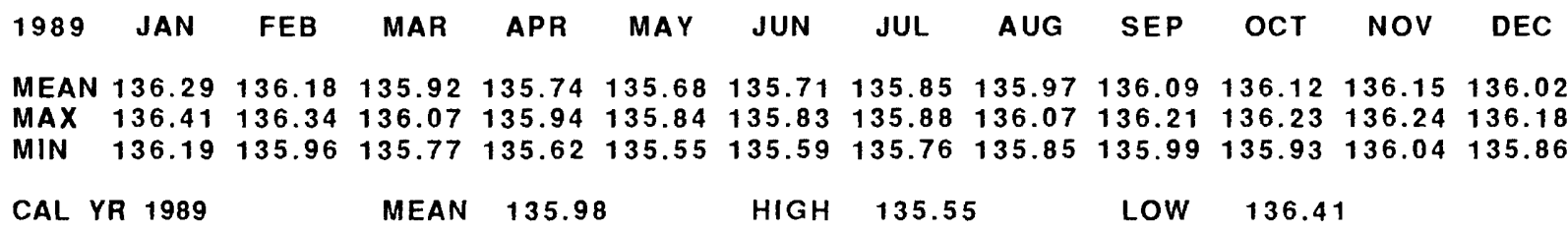

Figure 90.--Water level in observation well 24V001, Johnson County. 
325232082131501 Local number, $28 \times 001$.

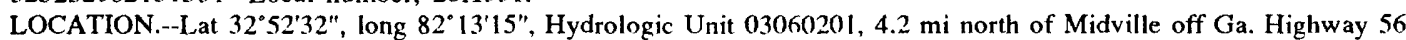
at Southeastern Experiment Station.

Owner: U.S. Geological Survey, Midville Experiment Station 1.

AQUIFER.--Midville aquifer system.

WELL CHARACTERISTICS.--Drilled observation well, diameter 4 in., depth 1,045 ft, cased to 1,025 ft, screen to $1,045 \mathrm{ft}$.

DATUM.--Altitude of land-surface datum is $269 \mathrm{ft}$.

Measuring point: Top of recorder shelf, $3.04 \mathrm{ft}$ above land-surface datum.

REMARKS.--Borehole geophysical survey conducted March 8 and April 22, 1980. Water-quality analyses May 23, 1980.

Water levels for period of missing record, May 6-23, were estimated.

PERIOD OF RECORD.--June 1980 to current year.

EXTREMES FOR PERIOD OF RECORD.--Highest water level, $49.07 \mathrm{ft}$ below land-surface datum, June 4, 1980: lowest,

$59.34 \mathrm{ft}$ below land-surface datum, December 2, 1988.
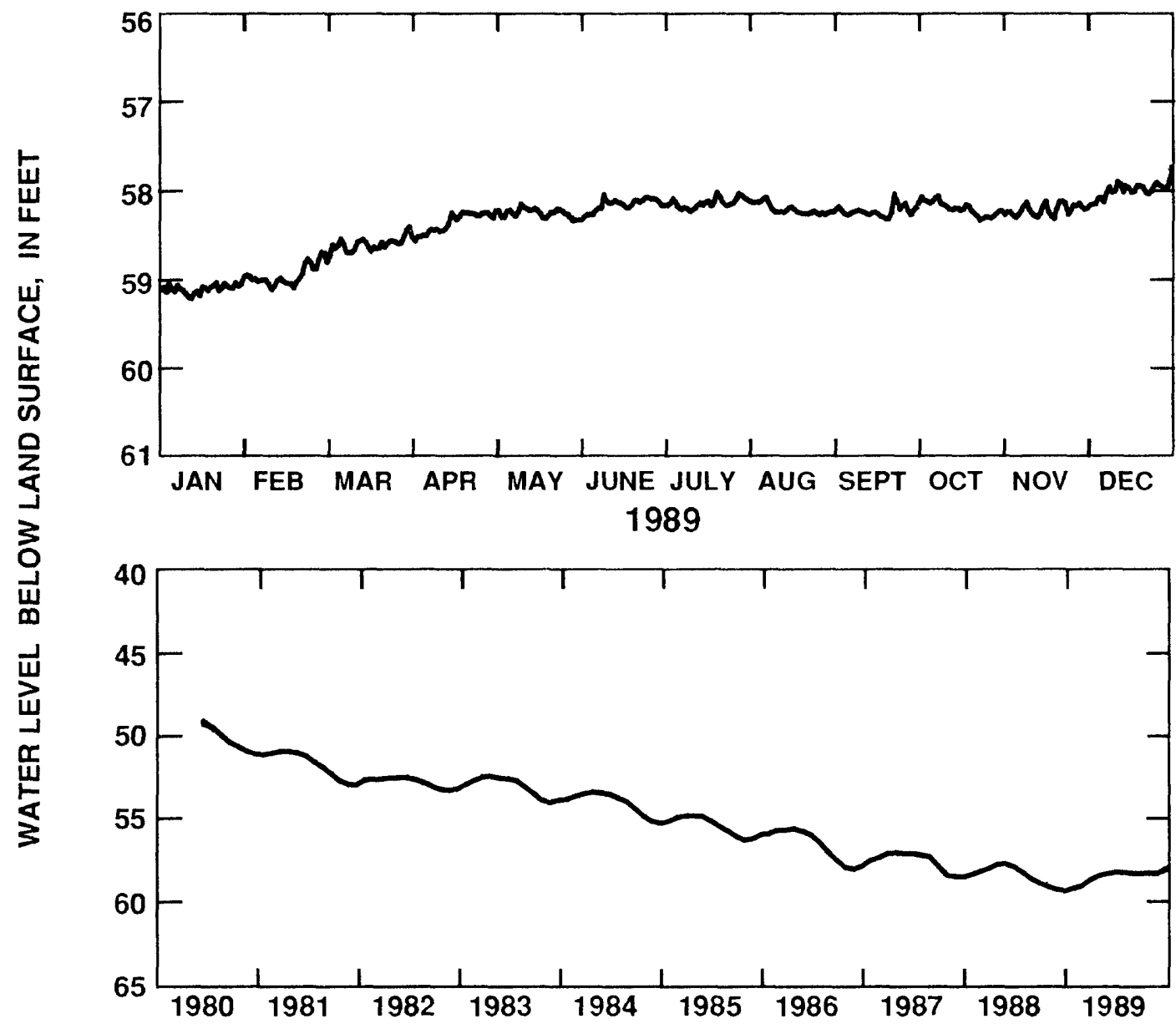

\begin{tabular}{|c|c|c|c|c|c|c|c|c|c|c|c|c|}
\hline 1989 & JAN & FEB & MAR & APR & MAY & JUN & JUL & AUG & SEP & OCT & NOV & DEC \\
\hline $\begin{array}{l}\text { MEAN } \\
\text { MAX } \\
\text { MIN }\end{array}$ & $\begin{array}{l}59.10 \\
59.22 \\
58.96\end{array}$ & $\begin{array}{l}58.96 \\
59.12 \\
58.70\end{array}$ & $\begin{array}{l}58.61 \\
58.81 \\
58.41\end{array}$ & $\begin{array}{l}58.37 \\
58.57 \\
58.24\end{array}$ & $\begin{array}{l}58.25 \\
58.34 \\
58.15\end{array}$ & $\begin{array}{l}58.16 \\
58.33 \\
58.05\end{array}$ & $\begin{array}{l}58.14 \\
58.23 \\
58.02\end{array}$ & $\begin{array}{l}58.21 \\
58.27 \\
58.08\end{array}$ & $\begin{array}{l}58.23 \\
58.32 \\
58.04\end{array}$ & $\begin{array}{l}58.20 \\
58.33 \\
58.06\end{array}$ & $\begin{array}{l}58.22 \\
58.32 \\
58.12\end{array}$ & $\begin{array}{l}58.01 \\
58.20 \\
57.85\end{array}$ \\
\hline CAL YF & 1989 & & MEAN & 58.37 & & $\mathrm{HIGH}$ & 57.85 & & LOW & 59.22 & & \\
\hline
\end{tabular}

Figure 91.--Water level in observation well 28X001, Burke County. 


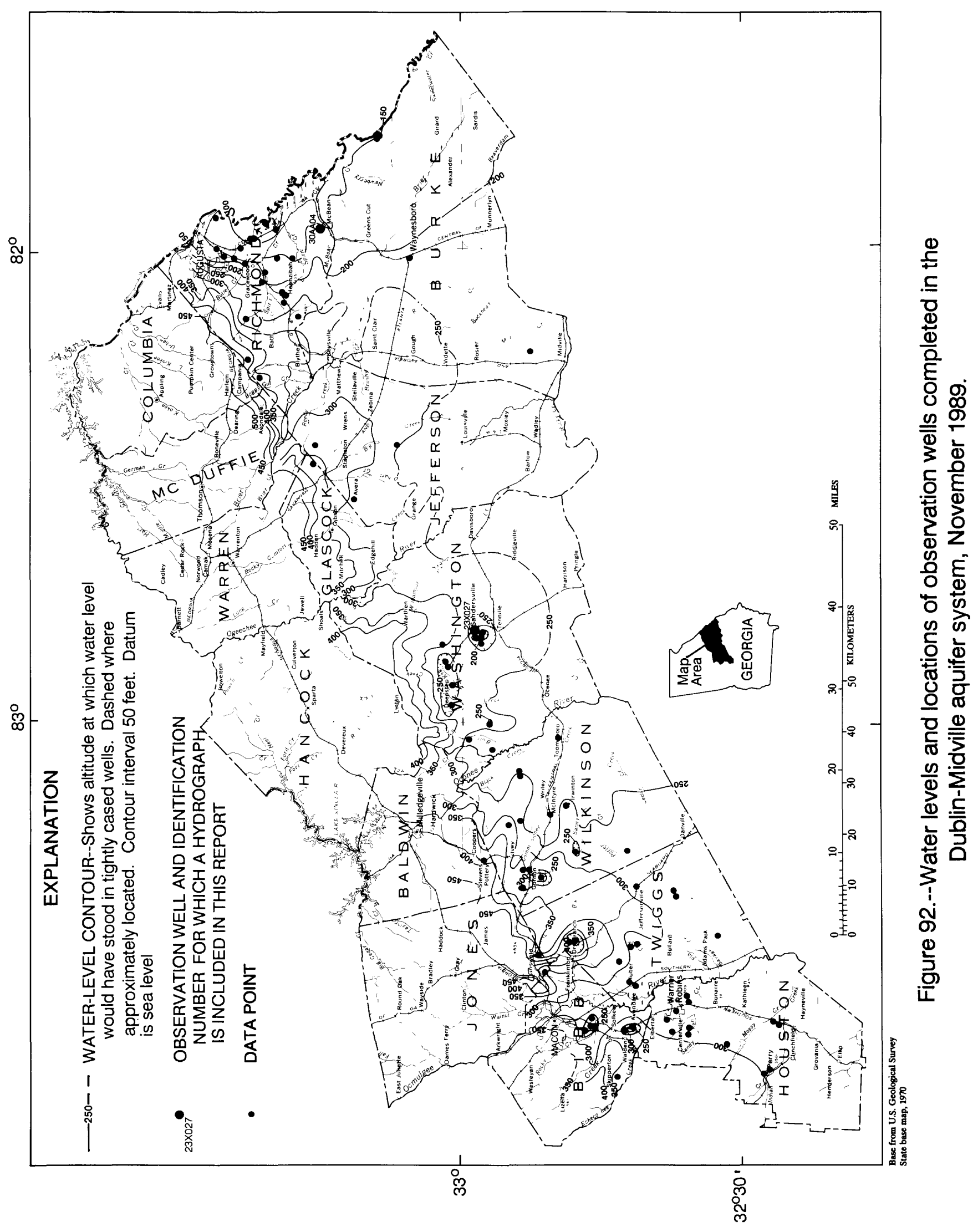


331711081573701 Local number, 30AA04.

LOCATION.--lat 33'15'25", long 81 ${ }^{\circ} 57^{\prime} 47^{\prime \prime}$, Hydrologic Unit 03060106, $1.5 \mathrm{mi}$ north of McBean, $0.65 \mathrm{mi}$ south of

Little McBean Creek, 0.5 mi west of Ga. Higliway 56.

Owner: Richmond County water system, U.S. Geological Survey McBean 2.

AQUIFTR.--Dublin-Midville aquifer system.

WIaL CHARACTERISTICS..-Drilled unused municipal well, diameter $6 \mathrm{in.}$, depth $496 \mathrm{fh}$ cased to $174 \mathrm{ft}$, screened intervals, 174-192 ft, 299-319 fh, 341-372 ft, and 393-434 ft.

DATUM.--Altitude of land-surface datum is $293 \mathrm{ft}$.

Measuring point: Top of 6 in. casing, $1.5 \mathrm{ft}$ above land-surface datum.

REMARKS.--Borehole geophysical survey conducted October 23, 1967. Water-quality sample collected November 26,

1967.

PERIOD OP RECORD.--June 1979 to current year.

EXTREMES FOR PERJOD OF RECORD.--Higlest water level, $116.70 \mathrm{ft}$ below land-surface datum, May 30, 1984; lowest,

$129.61 \mathrm{ft}$ below land-surface datum, August 28, 1988.
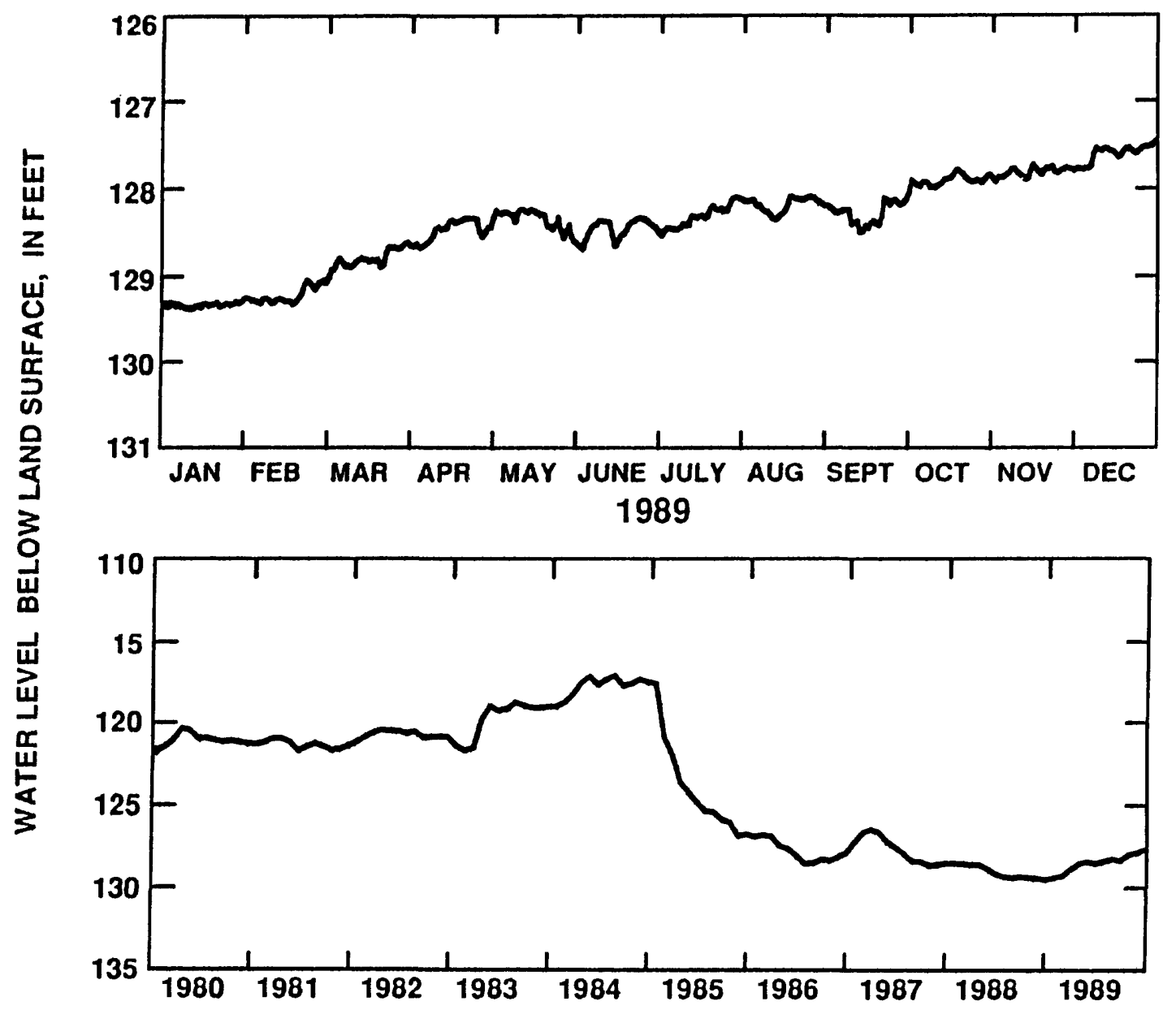

\begin{tabular}{|c|c|c|c|c|c|c|c|c|c|c|c|c|}
\hline 1989 & JAN & FEB & MAR & APR & MAY & JUN & JUL & AUG & SEP & OCT & NoV & DEC \\
\hline $\begin{array}{l}\text { MEAN } \\
\text { MAX } \\
\text { MIN }\end{array}$ & $\begin{array}{l}129.33 \\
129.37 \\
129.25\end{array}$ & $\begin{array}{l}129.22 \\
129.32 \\
129.04\end{array}$ & $\begin{array}{l}128.80 \\
129.07 \\
128.61\end{array}$ & $\begin{array}{l}128.47 \\
128.67 \\
128.33\end{array}$ & $\begin{array}{l}128.34 \\
128.60 \\
128.23\end{array}$ & $\begin{array}{l}128.45 \\
128.68 \\
128.33\end{array}$ & $\begin{array}{l}128.32 \\
128.53 \\
128.10\end{array}$ & $\begin{array}{l}128.18 \\
128.35 \\
128.09\end{array}$ & $\begin{array}{l}128.28 \\
128.50 \\
128.10\end{array}$ & $\begin{array}{l}127.91 \\
128.05 \\
127.78\end{array}$ & $\begin{array}{l}127.81 \\
127.92 \\
127.72\end{array}$ & $\begin{array}{l}127.60 \\
127.79 \\
127.45\end{array}$ \\
\hline CAL Y & ' 1989 & & MEAN & 128.3 & & HIGH & 127.45 & & Low & 129.37 & & \\
\hline
\end{tabular}

Figure 93.--Water level in observation well 30AA04, Richmond County. 
325848082480901 Local number, $23 \times 027$.

LOCATION.--Lat 32'58'48", long 82.48'08", Hydrologic Unit 03070102, 3,000 $\mathrm{ft}$ south of the intersection of Ga. Highway

24 and Jordon Mill Road, and 3,100 ft south of the courthouse in Sandersville, east side of rsilroad.

Owner: City of Sandersville 8.

AQUIFER.--Dublin-Midville aquifer system.

WILLL CHERACTERISTICS.--Drilled unused municipal well, diameler 8 in., depth $750 \mathrm{fth}$ cased to $480 \mathrm{ft}$ screened

intervals, 480-485 ft, 605-610 ft, 650-655 fh, 695-700 ft, and 740-745 ft.

DATUM.--Altitude of land-surface datum is $450 \mathrm{ft}$.

Measuring point: Top of recorder shelf, $3.2 \mathrm{ft}$ above land-surface datum.

REMARKS.--Borehole geophysical survey conducted March 14, 1985. Well sounded to $672 \mathrm{ft}$ on March 14, 1985. Lower screens probably caved.

PIRIOD OF RECORD.--Msrch 14, 1985 to current year.

EXTREMES FOR PERIOD OF RECORD.--Highest wster level, 227.68 fi below land-surface datum, April 9, 1985; lowest, $245.93 \mathrm{ft}$ below land-surface datum, June 15,1988 .
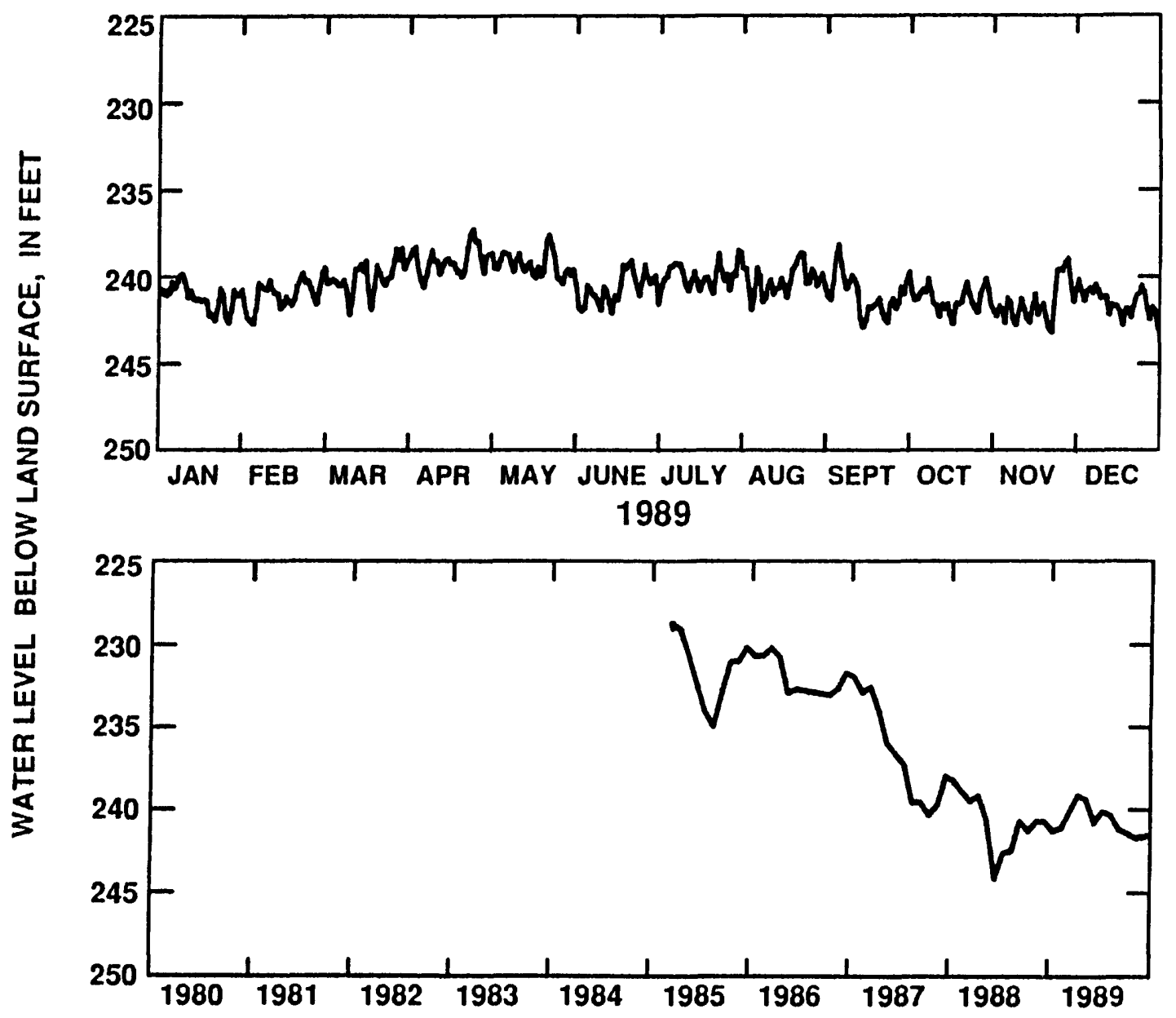

\begin{tabular}{|c|c|c|c|c|c|c|c|c|c|c|c|c|}
\hline 1989 & JAN & FEB & MAR & APR & MAY & JUN & JUL & AUG & SEP & OCT & NOV & DEC \\
\hline $\begin{array}{l}\text { MEAN } \\
\text { MAX } \\
\text { MIN }\end{array}$ & $\begin{array}{l}241.24 \\
242.71 \\
239.88\end{array}$ & $\begin{array}{l}241.07 \\
242.76 \\
239.84\end{array}$ & $\begin{array}{l}240.05 \\
242.24 \\
238.36\end{array}$ & $\begin{array}{l}239.09 \\
240.63 \\
237.28\end{array}$ & $\begin{array}{l}239.33 \\
240.44 \\
237.62\end{array}$ & $\begin{array}{l}240.72 \\
242.14 \\
239.13\end{array}$ & $\begin{array}{l}240.04 \\
241.64 \\
238.54\end{array}$ & $\begin{array}{l}240.30 \\
241.98 \\
238.69\end{array}$ & $\begin{array}{l}241.17 \\
243.03 \\
238.23\end{array}$ & $\begin{array}{l}241.38 \\
242.85 \\
239.88\end{array}$ & $\begin{array}{l}241.66 \\
243.35 \\
239.10\end{array}$ & $\begin{array}{l}241.59 \\
243.05 \\
240.33\end{array}$ \\
\hline CAL & & & MEAN & 240.6 & & HIGH & 237.28 & & LOW & 243.3 & & \\
\hline
\end{tabular}

Figure 94.--Water level in observation well $23 \times 027$, Washington County. 
At Sandersville, Washington County, the water level in the Dublin-Midville aquifer system is influenced primarily by local pumping. The mean water level in well 23 X027 (fig. 94), at Sandersville, was about the same in 1989 as in 1988, leveling off the downward trend that began in 1985.

\section{Paleozoic Rock Aquifers}

The water level in the Paleozoic rock aquifer in Walker County is monitored in well 03PP01 (figs. 95, 96). In this area, the water level in wells tapping the Paleozoic rock aquifers are affected primarily by precipitation and locally by pumping.

The mean water level in well 03PP01 was $2.9 \mathrm{ft}$ higher in 1989 than in 1988. Precipitation was above normal during much of the year, which resulted in increased recharge to the aquifer and higher water levels. (See precipitation graph for the Rome station, figure 4.) As a result of this increased recharge, a record high water level was measured in June 1989. The rapid response to precipitation shown on the hydrograph for well 03PP01 illustrates the effect of precipitation on water levels in areas having thin soil cover (figs. 4, 96).

\section{Crystalline Rock Aquifers}

Water-level fluctuations and trends in the crystalline rock aquifers are monitored in nine wells, records from four are included in this report (figs. 97-101). Ground-water levels in wells tapping the crystalline rock aquifers are affected mainly by precipitation and evapotranspiration, and locally by pumping. Generally, precipitation is heavy in winter and mid-summer and relatively light in spring and fall. During 1989, however, precipitation was above normal during most of the year (see precipitation graphs for the Cleveland, Athens, Clayton, and Atlanta stations, figs. 6, 7, 9, and 11). As a result of this above-normal precipitation, mean water levels generally were higher in 1989 than in 1988. The mean water levels in wells 10DD02 (fig. 98) in Fulton County, 11FF04 (fig. 99) in DeKalb County, 19HH12 (fig. 100) in Madison County, and 21BB04 (fig. 101) in Greene County were from 0.7 to $2.1 \mathrm{ft}$ higher in 1989 than in 1988. These rises reversed the downward waterlevel trend in wells 10DD02 and 19HH12. A record-high water level was measured in well 21BB04 in May 1989. 


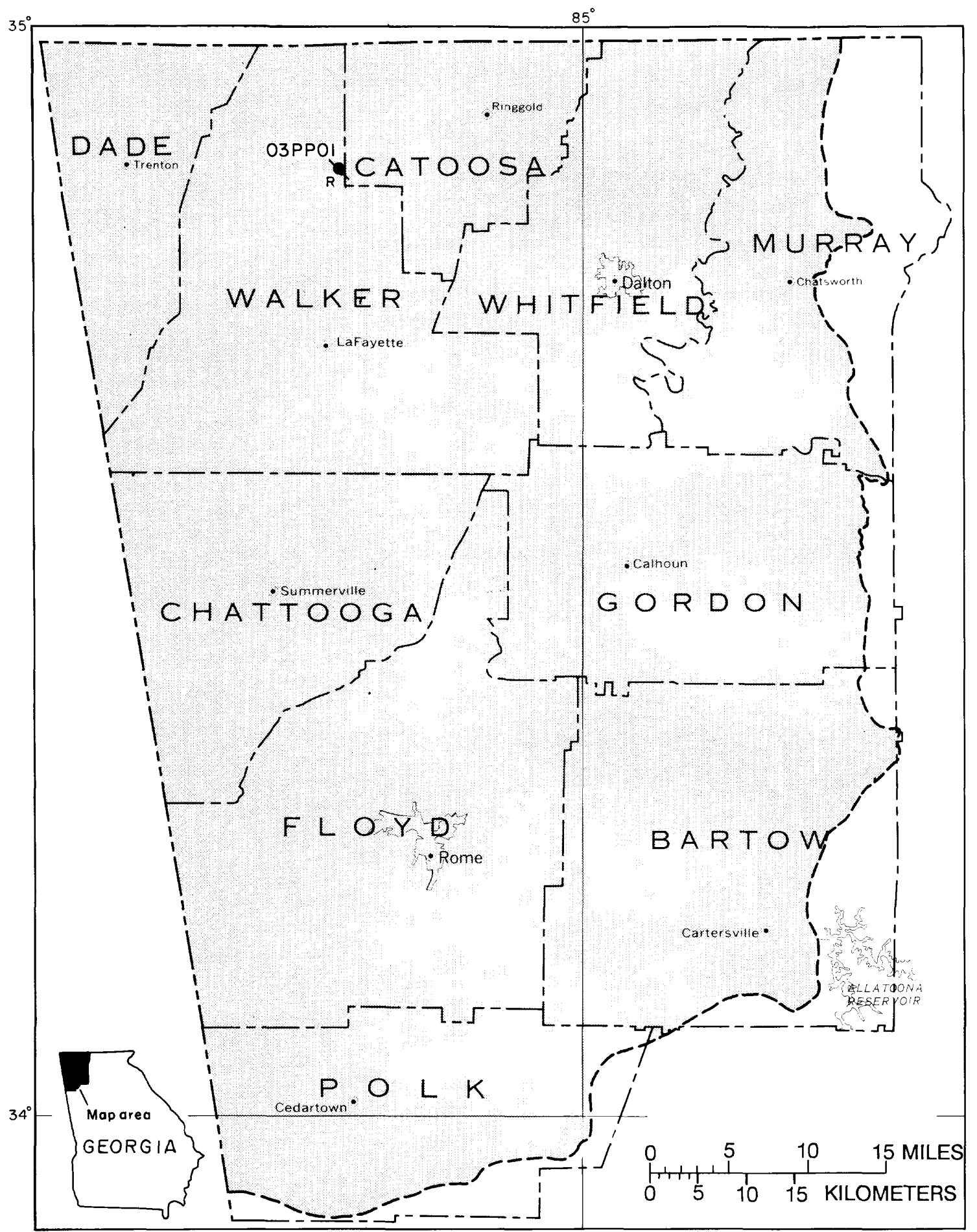

\section{EXPLANATION}

AREA OF PALEOZOIC ROCK AQUIFERS

O3PPOI

$R$ OBSERVATION WELL AND IDENTI-
FICATION NUMBER - equipped with recorder; hydrograph included in this report

Figure 95.--Location of observation well completed in the Paleozoic rock aquifers. 
345403085160001 Local number, 03PP01.

LOCATION.--Lat 34 $54^{\prime} 08^{\prime \prime}$, long 85'16'00", Hydrologic Unit 06020001, Chickamauga and Chattanooga National Military Park.

Owner: National Park Service, Fort Oglethorpe.

AQUIFER.--Paleozoic Rock (Chickamauga Limestone).

WELL CHARACTERISTICS.--Cable-tooled, observation well, diameter 8 in., depth $72 \mathrm{ft}$, cased to $11 \mathrm{ft}$, open hole.

DATUM.--Altitude of land-surface datum is $730 \mathrm{ft}$.

Measuring point: Pointer on recorder shelf, $2.09 \mathrm{ft}$ above land surface.

REMARKS.--Well sounded October 18, 1977. Water levels for period of missing record, June 15-26, were estimated.

PERIOD OF RECORD.--1977 to current year.

EXTREMES FOR PERIOD OF RECORD.--Highest water level, $1.97 \mathrm{ft}$ below land-surface datum, March 9, 1978; lowest,

$21.70 \mathrm{ft}$ below land-surface datum, August 5, 1978.
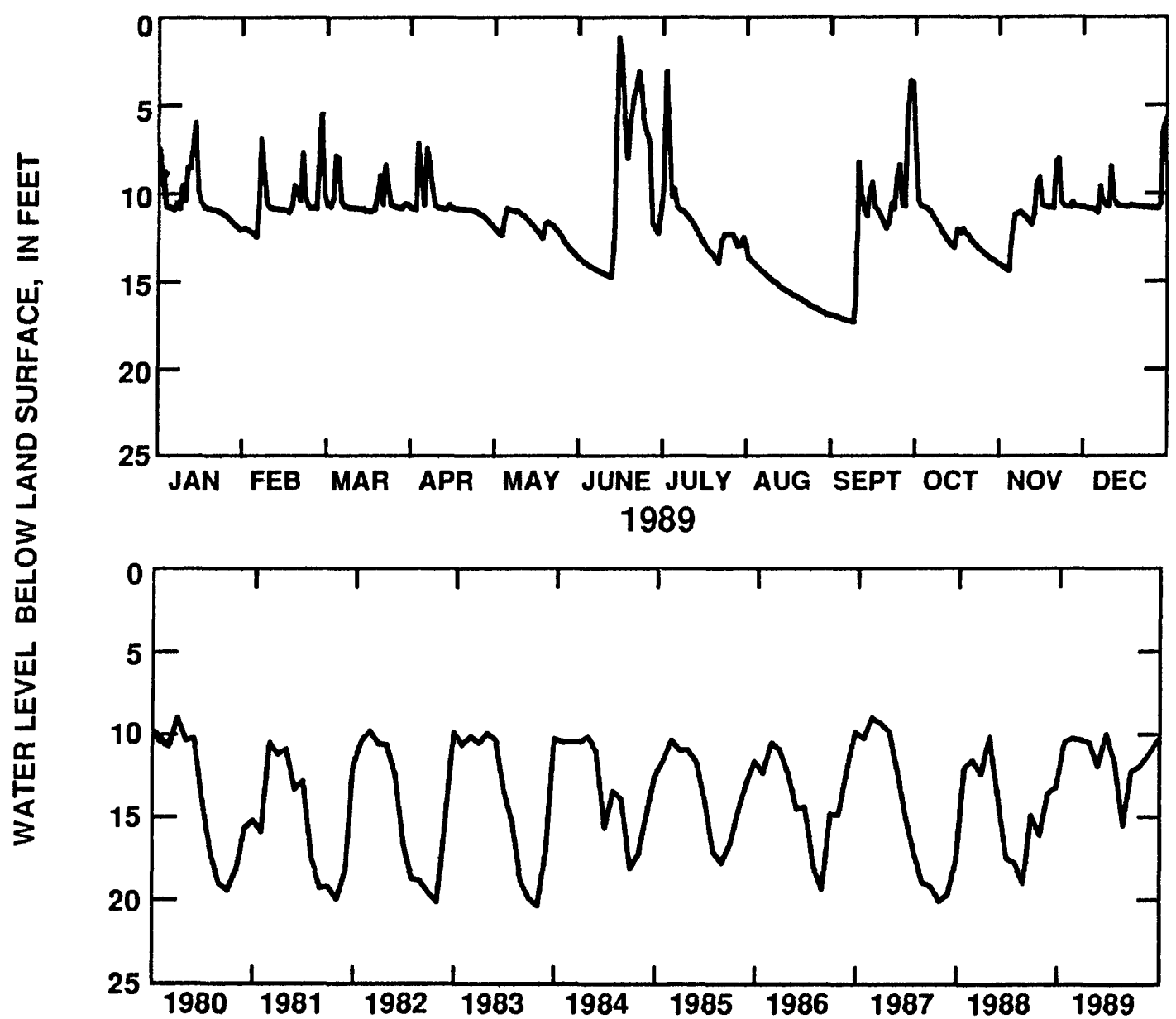

\begin{tabular}{|c|c|c|c|c|c|c|c|c|c|c|c|c|}
\hline 1989 & JAN & FEB & MAR & APR & MAY & JUN & JUL & AUG & SEP & OCT & NOV & DEC \\
\hline $\begin{array}{l}\text { MEAN } \\
\text { MAX } \\
\text { MIN }\end{array}$ & $\begin{array}{r}10.42 \\
11.98 \\
5.85\end{array}$ & $\begin{array}{r}10.22 \\
12.39 \\
5.43\end{array}$ & $\begin{array}{r}10.32 \\
10.96 \\
7.78\end{array}$ & $\begin{array}{r}10.49 \\
11.71 \\
7.07\end{array}$ & $\begin{array}{l}11.92 \\
13.47 \\
10.80\end{array}$ & $\begin{array}{r}10.95 \\
14.76 \\
4.52\end{array}$ & $\begin{array}{r}11.60 \\
13.94 \\
2.96\end{array}$ & $\begin{array}{l}15.47 \\
16.97 \\
12.96\end{array}$ & $\begin{array}{r}12.25 \\
17.37 \\
3.54\end{array}$ & $\begin{array}{r}11.95 \\
13.92 \\
3.69\end{array}$ & $\begin{array}{r}11.28 \\
14.45 \\
8.08\end{array}$ & $\begin{array}{r}10.56 \\
11.13 \\
6.72\end{array}$ \\
\hline AL & 1500 & & MEAN & 11.46 & & HIGH & 2.96 & & LOW & 17.37 & & \\
\hline
\end{tabular}

Figure 96.--Water level in observation well 03PP01, Walker County. 
${ }^{35^{\circ}-}$ $84^{\circ}$

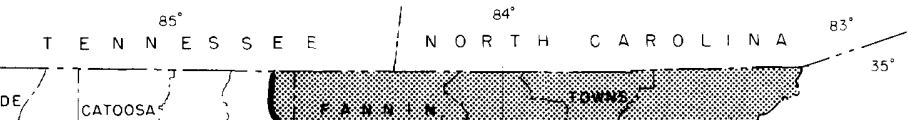

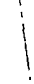

r

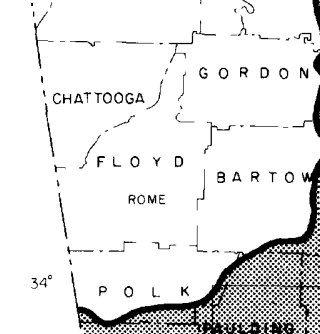

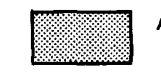

AREA OF CRYSTALLINE ROCK AQUIFERS

19HHI2

$Q_{R}$

OBSERVATION WELL AND IDENTIFICATION NUMBER--Equipped with recorder; hydrograph included in this report

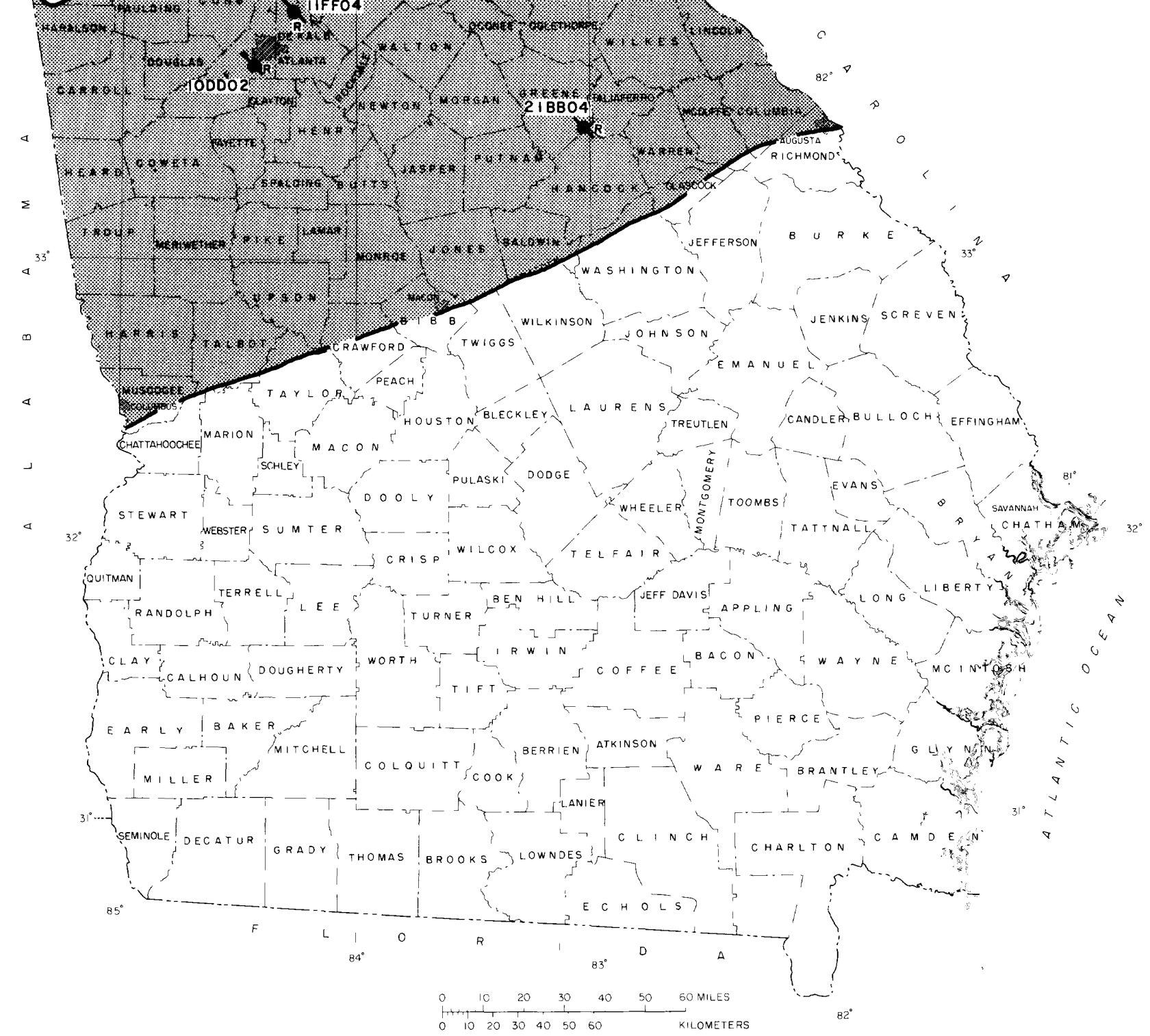

Figure 97.--Locations of observation wells completed in the crystalline rock aquifers. 
334207084254801 Local number, 10DD02.

LOCATION.-Lat 33 42'07", long $84^{\circ} 25^{\prime} 48^{\prime \prime}$, Hydrologic Unit 03130002, $100 \mathrm{ft}$ east of parking lot at main entrance.

Owner: U.S. Army, Fort McPherson.

AQUIFER.--Crystalline rock (Biotite gneiss).

WELL CHARACTERISTICS.--Drilled unused supply well, diameter $12 \mathrm{in}$., depth $338 \mathrm{ft}$, cased to $41 \mathrm{ft}$, open hole.

DATUM.--Altitude of land-surface datum is $1,013 \mathrm{ft}$.

Measuring point: Top of recorder shelf, $3.45 \mathrm{ft}$ above land-surface datum.

REMARKS.--Well pumped and sounded February 14, 1976, to a depth of $338 \mathrm{ft}$. Well pumped and water sample collected

November 26, 1985. Borehole geophysical survey conducted November 19, 1974. Water levels for period of

missing record, December 22-26, were estimated.

PERIOD OF RECORD.--November 1973 to current year.

EXTREMES FOR PERIOD OF RECORD.--Highest water level, $0.10 \mathrm{ft}$ below land-surface datum, March 30, 1980; lowest, $10.95 \mathrm{ft}$ below land-surface datum, September 2, 1988.
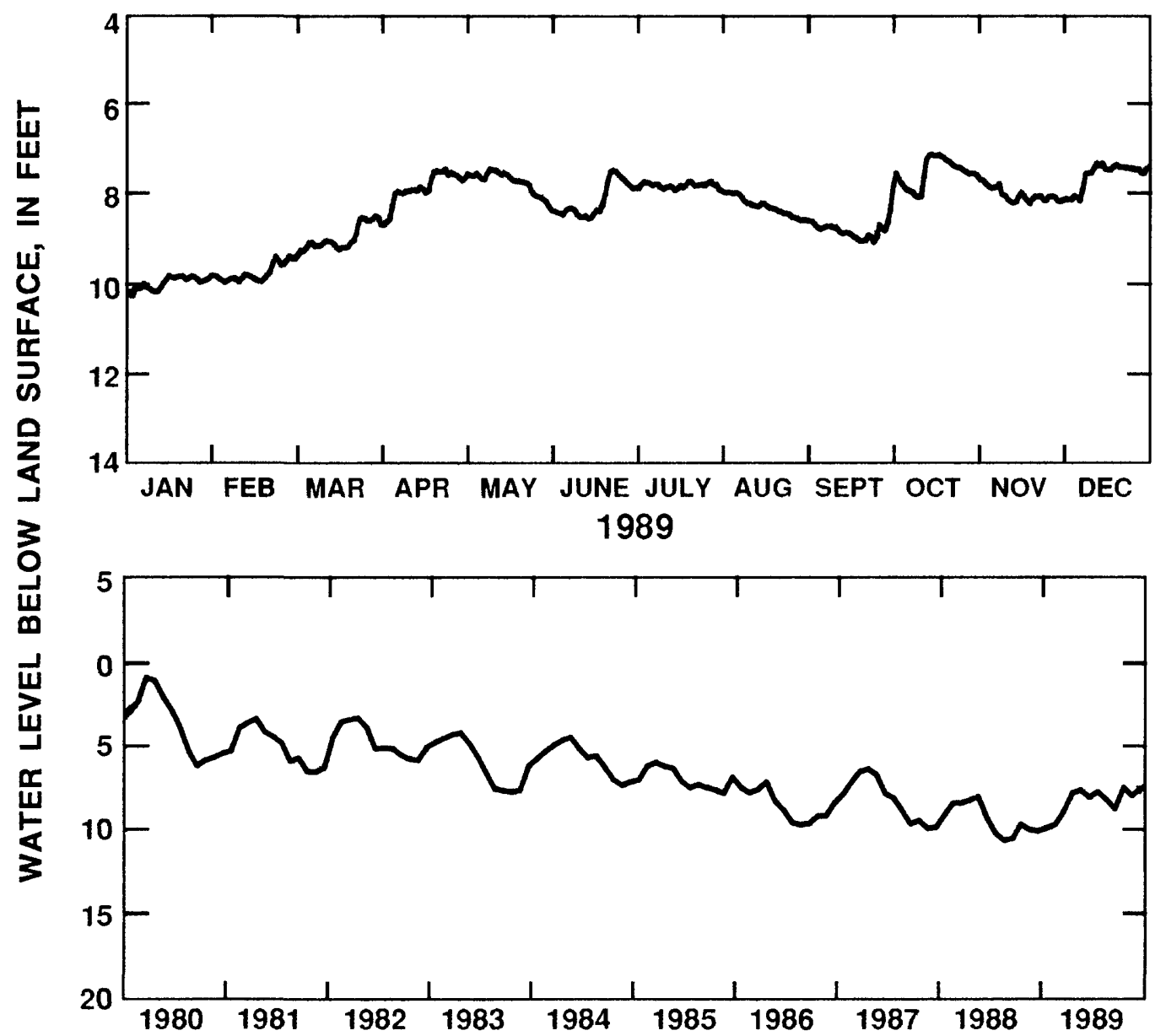

\begin{tabular}{|c|c|c|c|c|c|c|c|c|c|c|c|c|}
\hline 1989 & JAN & FEB & MAR & APR & MAY & JUN & JUL & AUG & SEP & OCT & NoV & DEC \\
\hline $\begin{array}{l}\text { MEAN } \\
\text { MAX } \\
\text { MIN }\end{array}$ & $\begin{array}{r}9.94 \\
10.21 \\
9.79\end{array}$ & $\begin{array}{l}9.74 \\
9.94 \\
9.35\end{array}$ & $\begin{array}{l}8.96 \\
9.40 \\
8.46\end{array}$ & $\begin{array}{l}7.86 \\
8.66 \\
7.41\end{array}$ & $\begin{array}{l}7.70 \\
8.27 \\
7.41\end{array}$ & $\begin{array}{l}8.13 \\
8.53 \\
7.45\end{array}$ & $\begin{array}{l}7.79 \\
7.90 \\
7.71\end{array}$ & $\begin{array}{l}8.26 \\
8.58 \\
7.92\end{array}$ & $\begin{array}{l}8.82 \\
9.08 \\
8.35\end{array}$ & $\begin{array}{l}7.54 \\
8.07 \\
7.12\end{array}$ & $\begin{array}{l}8.03 \\
8.23 \\
7.69\end{array}$ & $\begin{array}{l}7.62 \\
8.17 \\
7.33\end{array}$ \\
\hline CAL Y & 1989 & & MEAN & 8.36 & & HIGH & 7.12 & & LOW & 10.21 & & \\
\hline
\end{tabular}

Figure 98.--Water level in observation well 10DD02, Fulton County. 
335517084164001 Local number, 11 FFo4.

LOCATION.--Lat $33^{\circ} 55^{\circ} 17^{\prime \prime}$, long $84^{\circ} 16^{\prime} 40^{\prime \prime}$, Hydrologic Unit 03130001, 6481 Peachtree Industrial Boulevard, $55 \mathrm{ft}$ south of southe astern corner of building.

Owner: U.S. Geological Survey

AQUIFER.--Crystalline rock.

WELL CHARACTERISTICS.--Drilled observation well, diameter 6 in., depth $620 \mathrm{ft}$, cased to $36 \mathrm{ft}$, open hole.

DATUM.--Altitude of land-surface datum is $950 \mathrm{ft}$.

Measuring point: Top of recorder shelf, $3.0 \mathrm{ft}$ above land-surface datum.

REMARKS.--Borehole ge ophysical survey conducied April 18, 1980.

PERIOD OF RECORD.--February 1980 to current year.

EXTREMES FOR PERIOD OF RECORD.--Highest water level, $5.46 \mathrm{ft}$ below land-surface datum, February 2, 1983; lowest,

$7.66 \mathrm{ft}$ below land-surface datum, July 20, 1988.

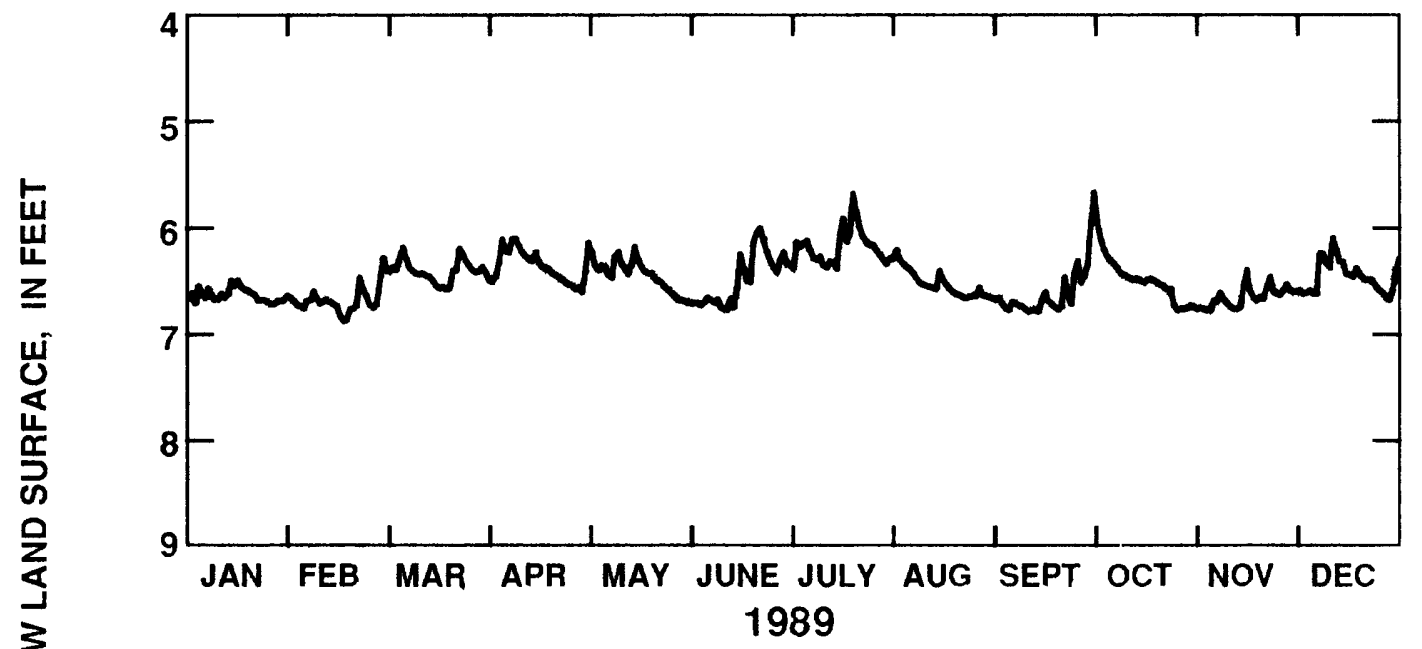

\begin{tabular}{|c|c|c|c|c|c|c|c|c|c|c|c|c|}
\hline 1989 & JAN & FEB & MAR & APR & MAY & JUN & JUL & AUG & SEP & OCT & NOV & DEC \\
\hline${ }^{A N}$ & $\begin{array}{l}6.62 \\
6.71 \\
6.48\end{array}$ & $\begin{array}{l}6.68 \\
6.87 \\
6.28\end{array}$ & $\begin{array}{l}6.40 \\
6.57 \\
6.17\end{array}$ & & $\begin{array}{l}6.43 \\
6.70 \\
6.13\end{array}$ & & & & & & $\begin{array}{l}6.67 \\
6.79 \\
6.41\end{array}$ & $\begin{array}{l}6.49 \\
6.70 \\
6.11\end{array}$ \\
\hline
\end{tabular}

CAL YR 1989

MEAN 6.50

HIGH $\quad 5.67$

LOW $\quad 6.87$

Figure 99.--Water level in observation well 11FF04, DeKalb County. 
341020083201701 Local number, $19 H \mathrm{H} 12$.

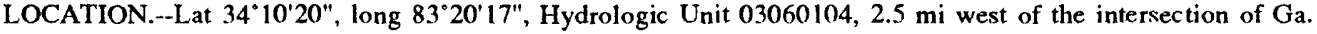

Highways 98 and 106 in Ila, approximately $0.8 \mathrm{mi}$ south of Ga. Highway 98 .

Owner: Meadowlake Estates.

AQUIFER.--Crystalline rock.

WELL CHARACTERISTICS.--Drilled unused supply well, diameter 6 in., depth $185 \mathrm{ft}$, cased to $50 \mathrm{ft}$, open hole.

DATUM.--Altitude of land-surface datum is $800 \mathrm{ft}$.

Measuring point: Top of recorder shelf, $3.0 \mathrm{ft}$ above land-surface datum.

REMARKS.--Water levels for periods of missing record, June 28 to July 12, and September 19 to October 3 , were

estimated.

PERIOD OF RECORD.--October 1983 to current year.

EXTREMES FOR PERIOD OF RECORD.--Highest water level, $6.69 \mathrm{ft}$ below land-surface datum, April 14, 1984; lowest,

$15.56 \mathrm{ft}$ below land-surface datum, September 2-3, 1988.
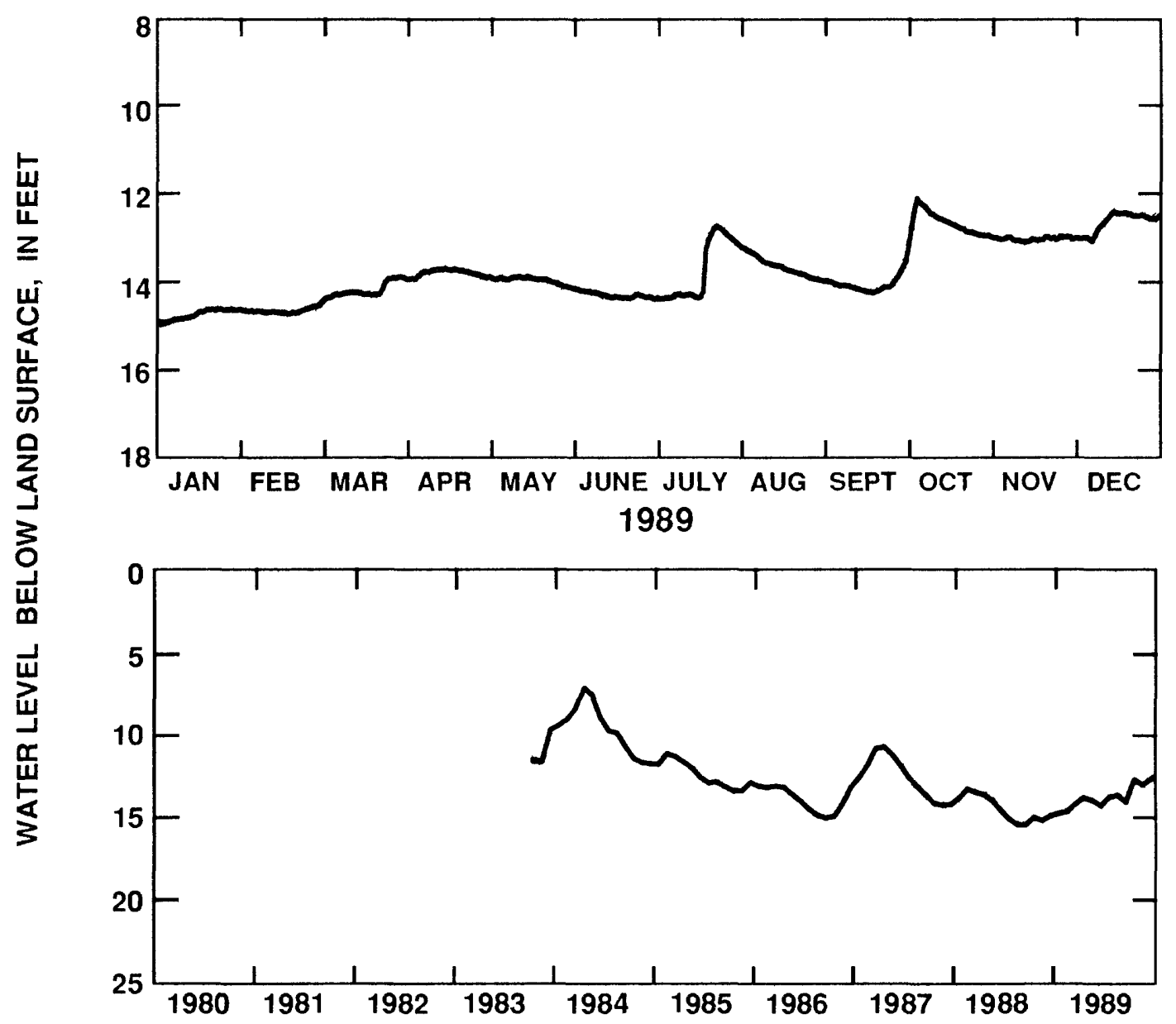

\begin{tabular}{|c|c|c|c|c|c|c|c|c|c|c|c|c|}
\hline 1989 & JAN & FEB & MAR & APR & MAY & JUN & JUL & AUG & SEP & OCT & NoV & DEC \\
\hline $\begin{array}{l}\text { MEAN } \\
\text { MAX } \\
\text { MIN }\end{array}$ & $\begin{array}{l}14.72 \\
14.93 \\
14.61\end{array}$ & $\begin{array}{l}14.64 \\
14.71 \\
14.50\end{array}$ & $\begin{array}{l}14.17 \\
14.43 \\
13.87\end{array}$ & $\begin{array}{l}13.78 \\
13.92 \\
13.68\end{array}$ & $\begin{array}{l}13.95 \\
14.12 \\
13.87\end{array}$ & $\begin{array}{l}14.27 \\
14.36 \\
14.13\end{array}$ & $\begin{array}{c}13.73 \\
14.36 \\
12.72\end{array}$ & $\begin{array}{l}13.63 \\
13.96 \\
13.19\end{array}$ & $\begin{array}{l}14.04 \\
14.23 \\
13.51\end{array}$ & $\begin{array}{l}12.66 \\
13.16 \\
12.10\end{array}$ & $\begin{array}{l}13.01 \\
13.07 \\
12.95\end{array}$ & $\begin{array}{l}12.64 \\
13.06 \\
12.39\end{array}$ \\
\hline CAL YF & 1989 & & MEAN & 13.76 & & HIGH & 12.10 & & LOW & 14.93 & & \\
\hline
\end{tabular}

Figure 100.--Water level in observation well $19 \mathrm{HH} 12$, Madison County. 
332808083010201 Local number, $21 \mathrm{BB} 04$.

LOCATION.--Lat $33^{\circ} 28^{\prime} 08^{\prime \prime}$, long $83^{\circ} 01^{\prime} 02^{\prime \prime}$, Hydrologic Unit $03070101,1.1 \mathrm{mi}$ east of Ga. Highway 17 at White

Plains, and $\mathbf{5 0} \mathrm{ft}$ north of the centerline of Veazey Road.

Owner: Charles Veazey.

AQUIFER.--Crystalline rock.

WELL CHARACTERISTICS.--Drilled unused supply well, diameter 6 in., depth $497 \mathrm{ft}$, cased to $15 \mathrm{ft}$, open hole.

DATUM.--Altitude of land-surface datum is $675 \mathrm{ft}$.

Measuring point: Top of recorder shelf, $2.5 \mathrm{ft}$ above land-surface datum.

REMARKS.--Borehole geophysical survey conducted March 13, 1987. Water levels for period of missing record,

June 9-10, were estimated.

PERIOD OF RECORD.--March 13, 1987 to current year.

EXTREMES FOR PERIOD OF RECORD.--Highest water level, $0.18 \mathrm{ft}$ above land-surface datum, May 11,1989 ; lowest,

$7.58 \mathrm{ft}$ below land-surface datum, December 7, 1987.
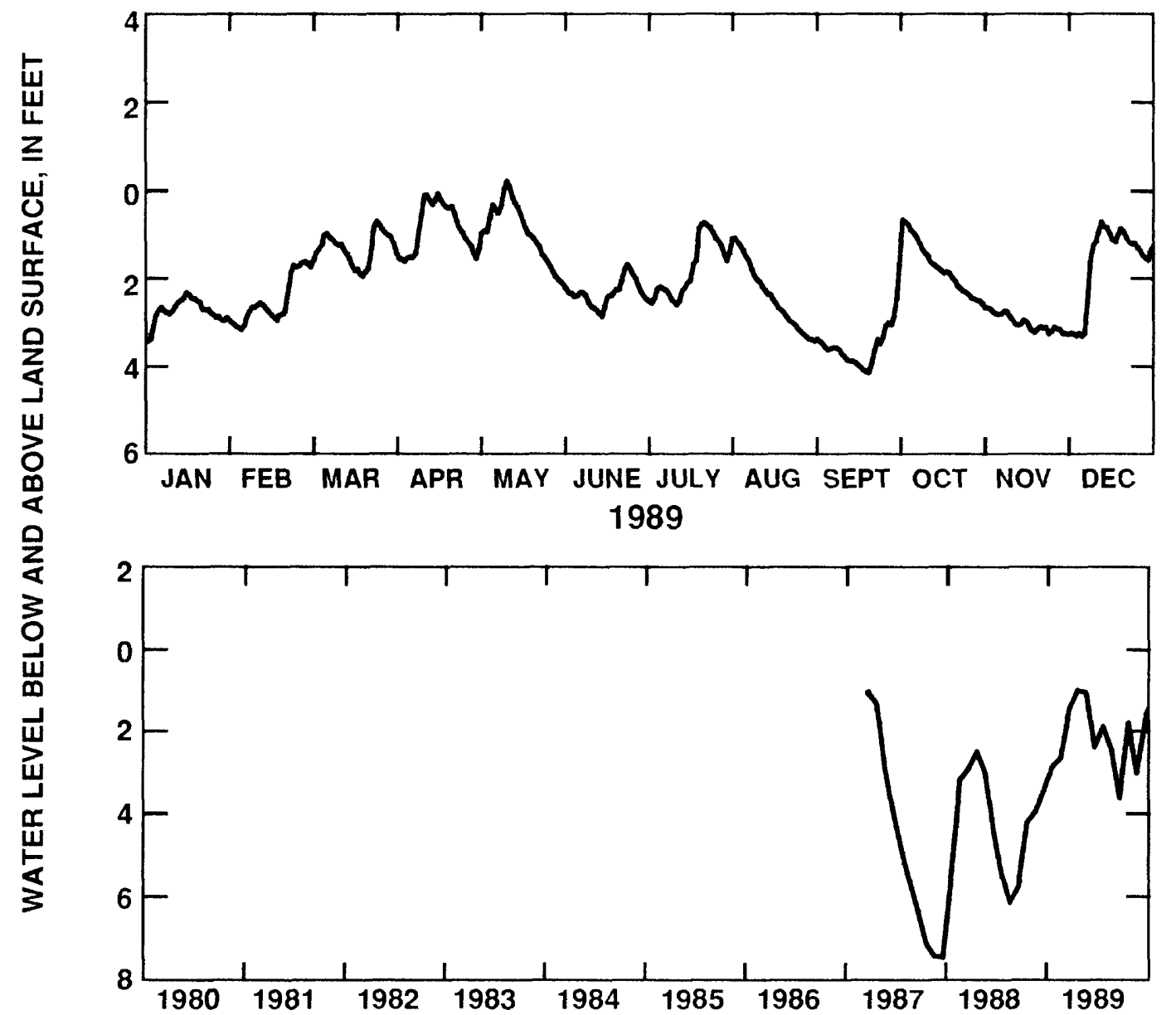

$\begin{array}{lrrrrrrrrrrrr}1989 & \text { JAN } & \text { FEB } & \text { MAR } & \text { APR } & \text { MAY } & \text { JUN } & \text { JUL } & \text { AUG } & \text { SEP } & \text { OCT } & \text { NOV } & \text { DEC } \\ \text { MEAN } & 2.78 & 2.56 & 1.35 & .89 & .94 & 2.30 & 1.79 & 2.36 & 3.53 & 1.69 & 2.93 & 1.61 \\ \text { MAX } & 3.44 & 3.19 & 1.96 & 1.63 & 2.07 & 2.84 & 2.57 & 3.37 & 4.08 & 2.50 & 3.18 & 3.23 \\ \text { MIN } & 2.36 & 1.65 & .73 & .10 & -.18 & 1.67 & .72 & 1.06 & 2.41 & .62 & 2.60 & .65\end{array}$

CAL YR 1989

MEAN 2.05

HIGH $\quad-.18$

Low

4.08

[Negative value Indicates water level above land surface]

Figure 101.--Water level in observation well 21BB04, Greene County. 


\section{CHLORIDE CONCENTRATIONS IN THE FLORIDAN AQUIFER SYSTEM}

Chloride concentrations in water from the Floridan aquifer system have been monitored periodically in coastal Georgia since the 1950's. Chloride concentrations in the Upper Floridan aquifer over most of the coastal Georgia area are less than $40 \mathrm{mg} / \mathrm{L}$ (Clarke and others, 1990, p. 48), which is withm the $250 \mathrm{mg} / \mathrm{L}$ drinking-water standard established by the Georgia Department of Natural Resources (1977) and the U.S. Environmental Protection Agency (1986b). Chloride concentrations in the Upper Floridan aquifer that exceed drinking-water standards have been detected only in the Brunswick area.

\section{Savannah Area}

Saltwater has the potential to enter the Floridan aquifer system in the Savannah area by encroachment from the sea or to a lesser extent, by upconing (upward leakage) from deeper zones (Clarke and others, 1990, p. 48). Chloride concentrations in the Upper Floridan aquifer in the Savannah area generally increase toward the eastern part of Chatham County (Joiner and others, 1989, p. 162).

At Savannah, 12 wells are sampled on a monthly basis, records from five are included in this report (figs. 102-103). Data from these wells indicate that chloride concentrations generally increase with depth below land surface in the Savannah area (fig. 103). This increase is illustrated by chloride graphs for one well tapping the Upper Floridan aquifer and four wells tapping the Lower Floridan aquifer. During 1989, water samples from well 37Q185 (interval tapped 274-360 ft) tapping the Upper Floridan aquifer had concentrations of less than $10 \mathrm{mg} / \mathrm{L}$. In the Lower Floridan aquifer, water samples from well $38 \mathrm{Q} 004$ (interval tapped 606-657) had concentrations of less than $200 \mathrm{mg} / \mathrm{L}$. However, water samples from wells 39Q018 (interval tapped, 630-670 ft) and 390017 (interval tapped, 710-745 ft) had concentrations of less than $900 \mathrm{mg} / \mathrm{L}$, and water samples from well 38Q196 (interval tapped, 870-925 ft) had chloride concentrations of 5,300 to 5,500 mg/L in 1989 .

Chloride concentrations in the Floridan aquifer system at Savannah showed little change during 198089 (fig. 103). In the Upper Floridan aquifer, chloride concentrations in water from well 37Q185 ranged from 2 to $7 \mathrm{mg} / \mathrm{L}$ during 1986-89. During the same period, the chloride concentrations in water from the Lower Floridan aquifer ranged from 160 to $170 \mathrm{mg} / \mathrm{L}$ in well $38 \mathrm{Q} 004$, from 600 to $620 \mathrm{mg} / \mathrm{L}$ in well $39 \mathrm{Q} 018$, and from 820 to $840 \mathrm{mg} / \mathrm{L}$ in well $37 \mathrm{Q} 017$. The concentration in water from well 38Q196, tapping the Lower Floridan aquifer increased from 5,300 mg/L in January 1980 to 5,400 mg/L in December 1989.

\section{Brunswick Area}

Since pumping began in the Brunswick area in the late 1800's, ground-water withdrawal has lowered the water level in the Upper Floridan aquifer. This water-level decline has allowed saltwater to migrate upward into the Upper Floridan aquifer in Brunswick where chloride concentrations in the upper water-bearing zone are greater than $2,000 \mathrm{mg} / \mathrm{L}$ at three known locations.

About 80 wells in Glynn County, mostly in the Brunswick area, are pumped and sampled semi-annually for chloride analysis (fig. 104). Chloride graphs from eight of these wells are included in this report (figs. 105, 106). Observed changes in chloride concentrations in these wells may be attributed to areal variations in pumping that have altered water-level gradients; and thus, the direction of chloride migration. 

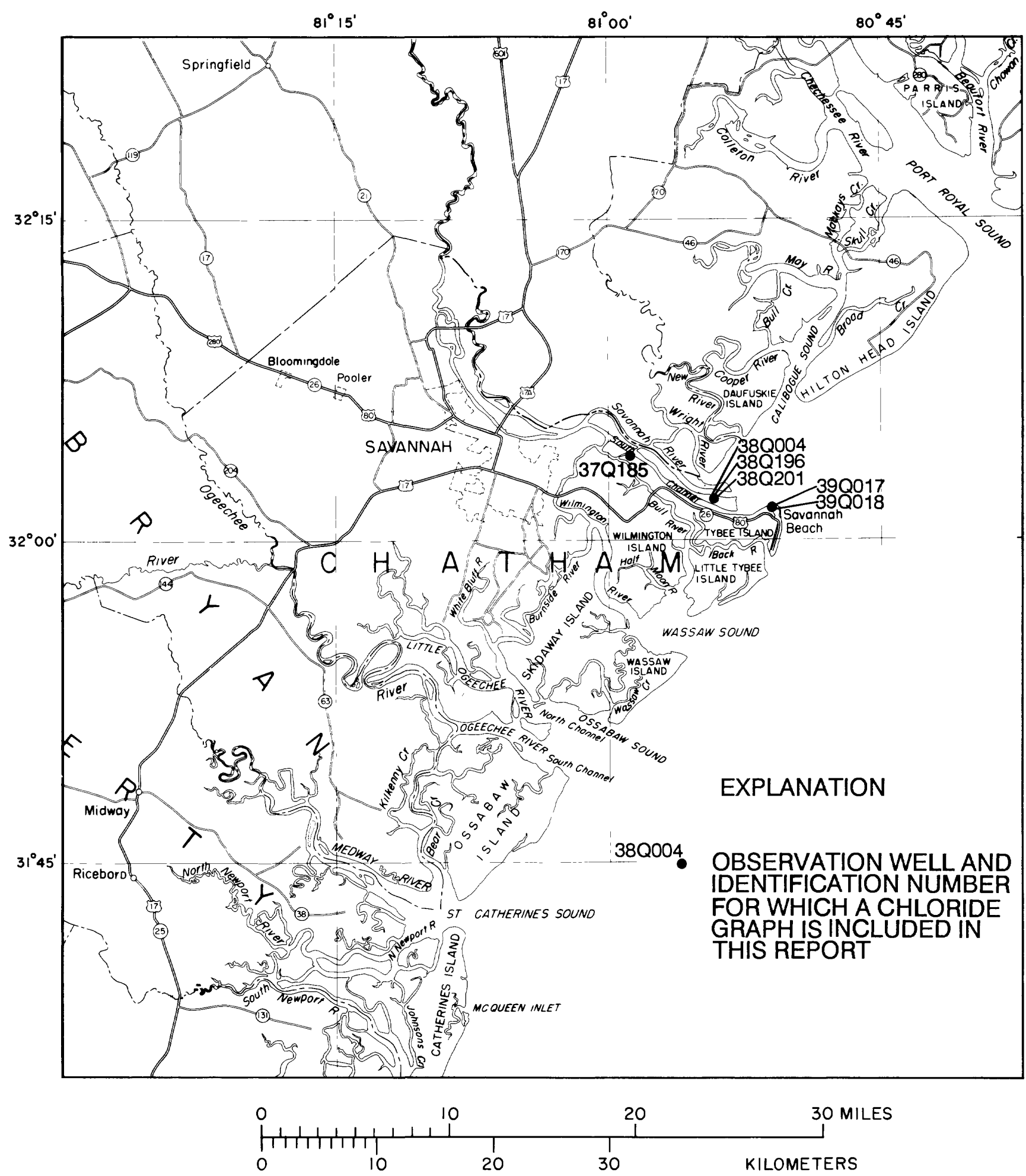

Figure 102.--Locations of chloride-monitoring wells completed in the Floridan aquifer sysytem in the Savannah area. 


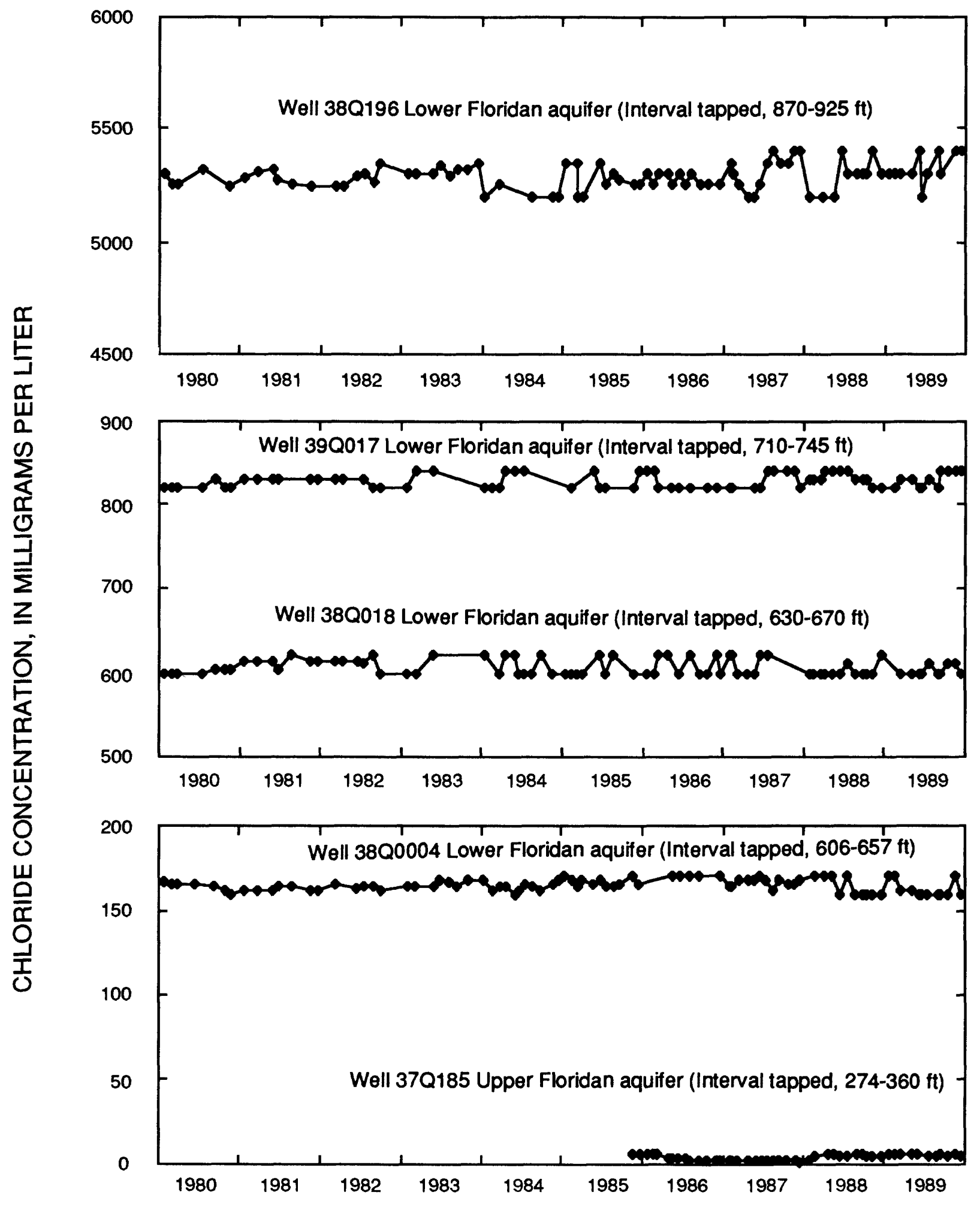

Figure 103.-- Chloride concentrations in the Upper and Lower Floridan aquifers in the Savannah area. 


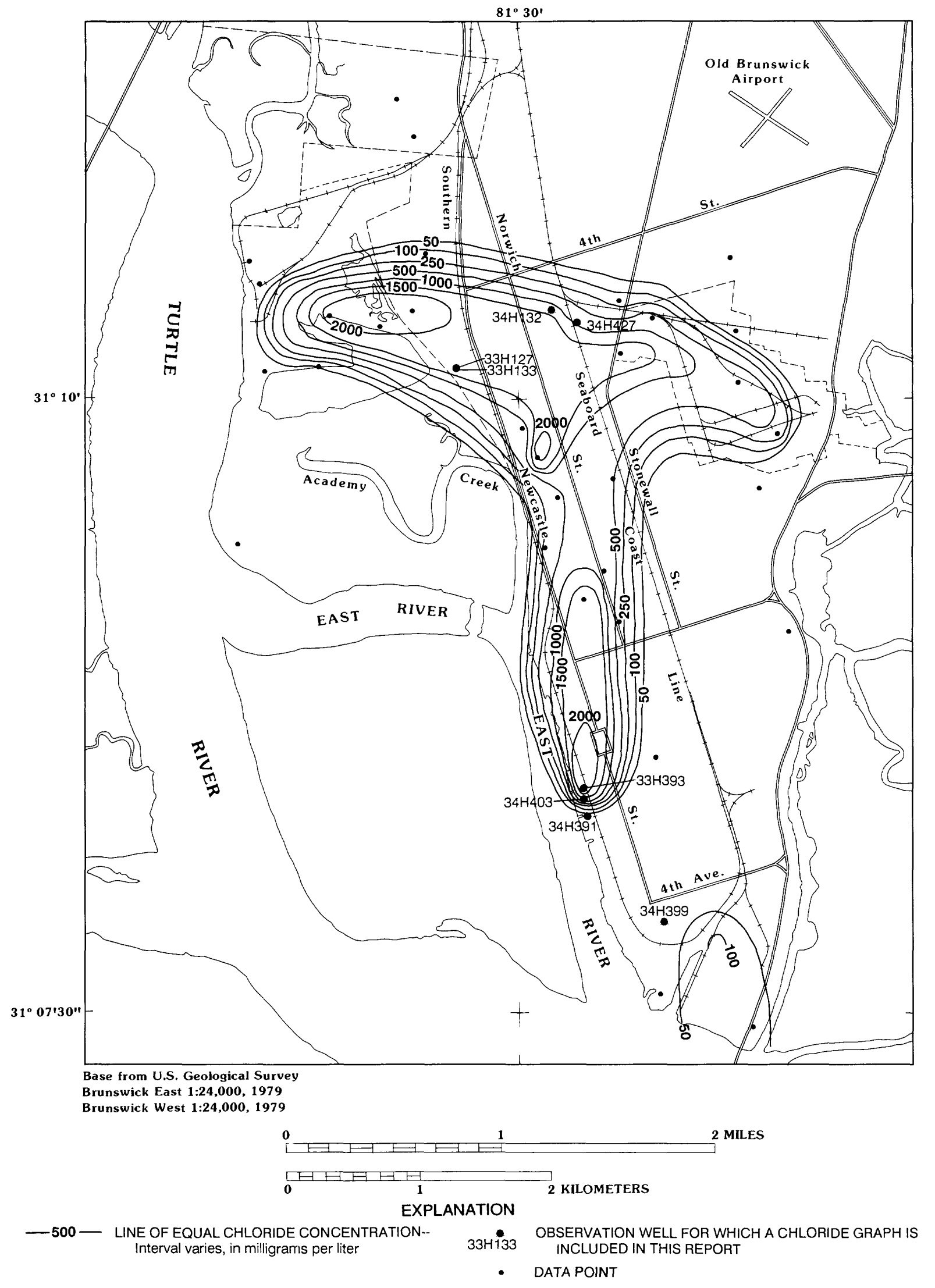

Figure 104.--Chloride concentrations and locations of chloride-monitoring wells in the upper water-bearing zone of the Upper Floridan aquifer in the Brunswick area, October 1989. 


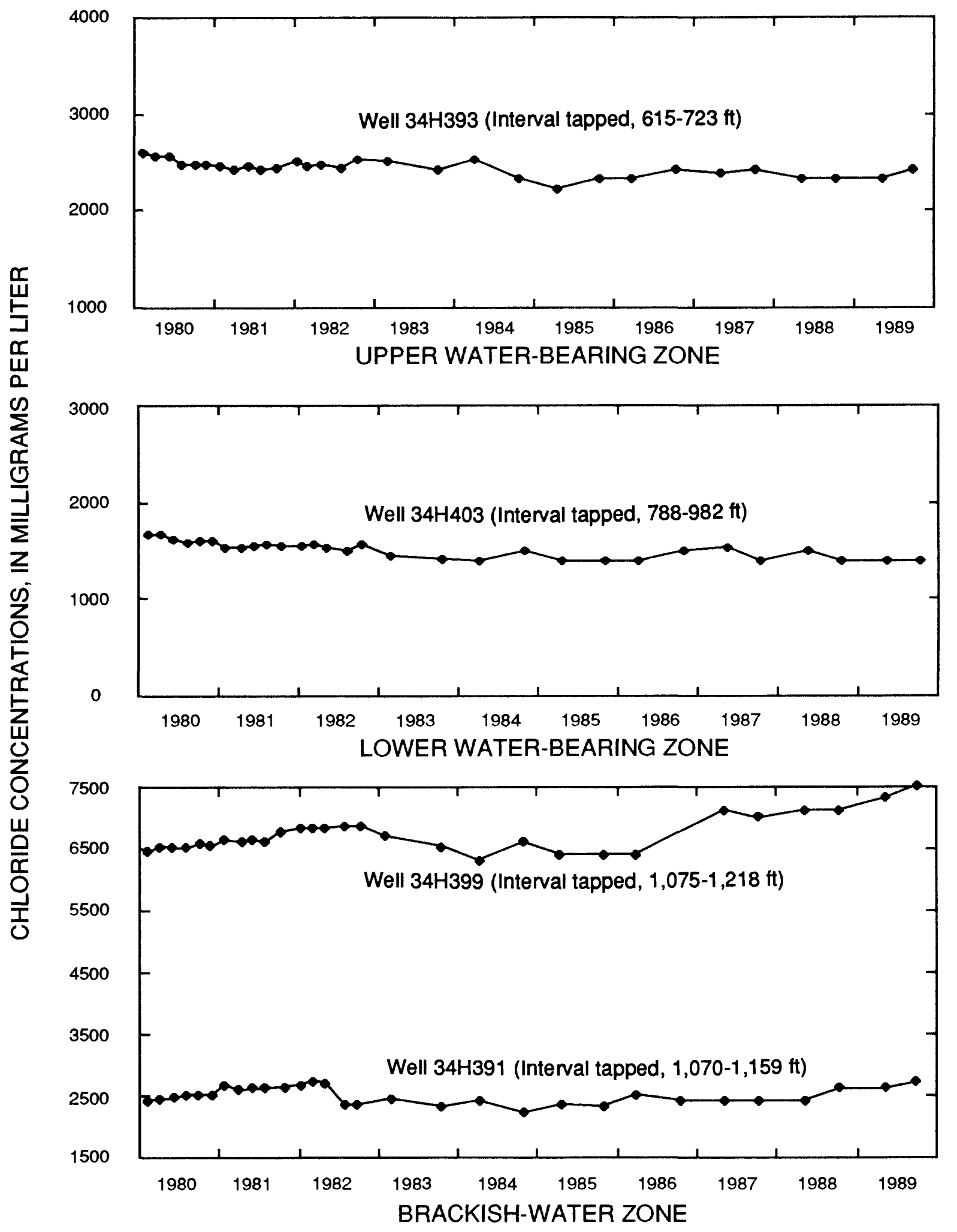

Figure 105.--Chloride concentrations in the Floridan aquifer system in the Bay Street area of Brunswick 


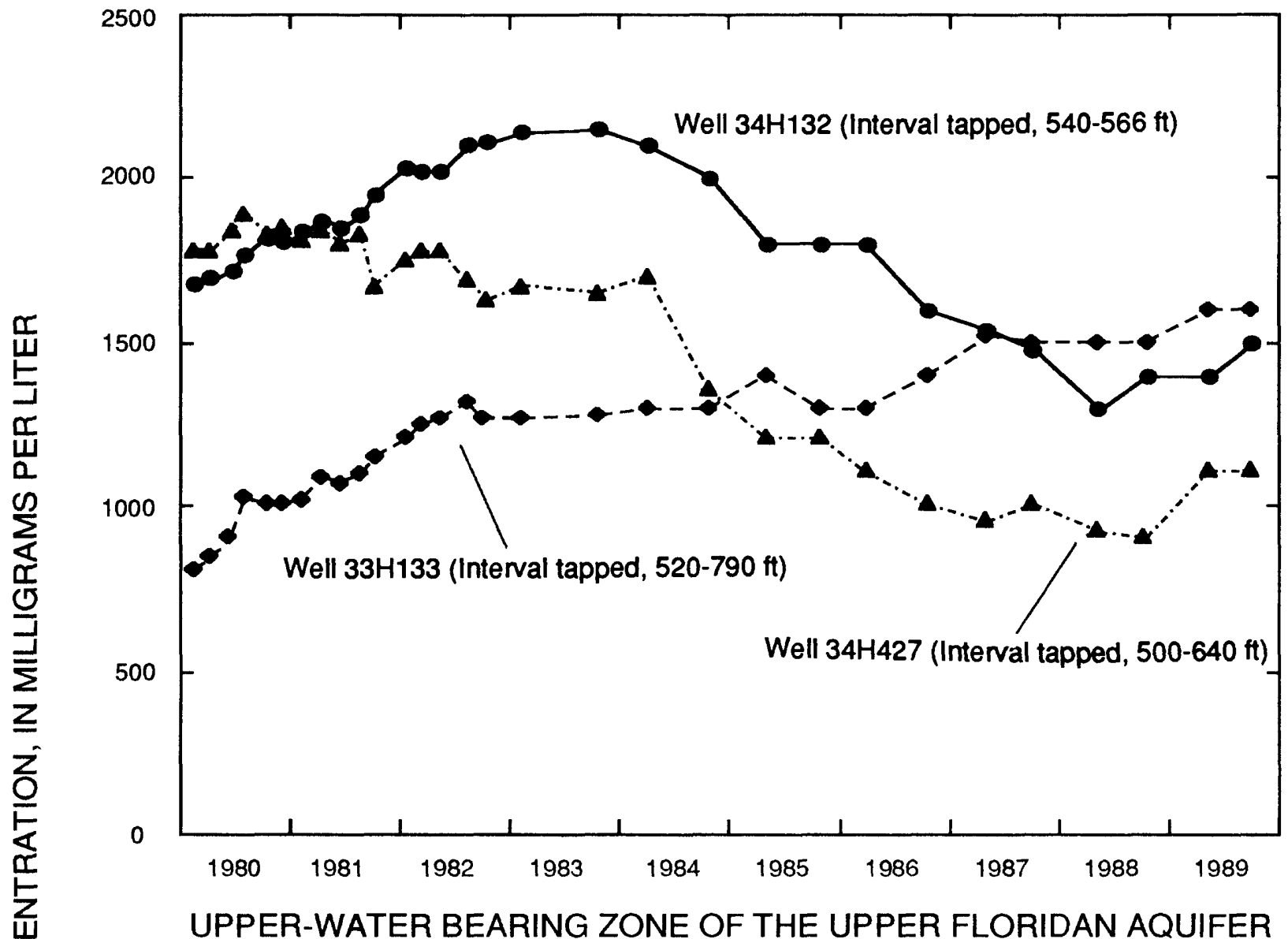

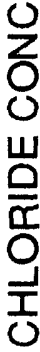

UPPER-WATER BEARING ZONE OF THE UPPER FLORIDAN AQUIFER

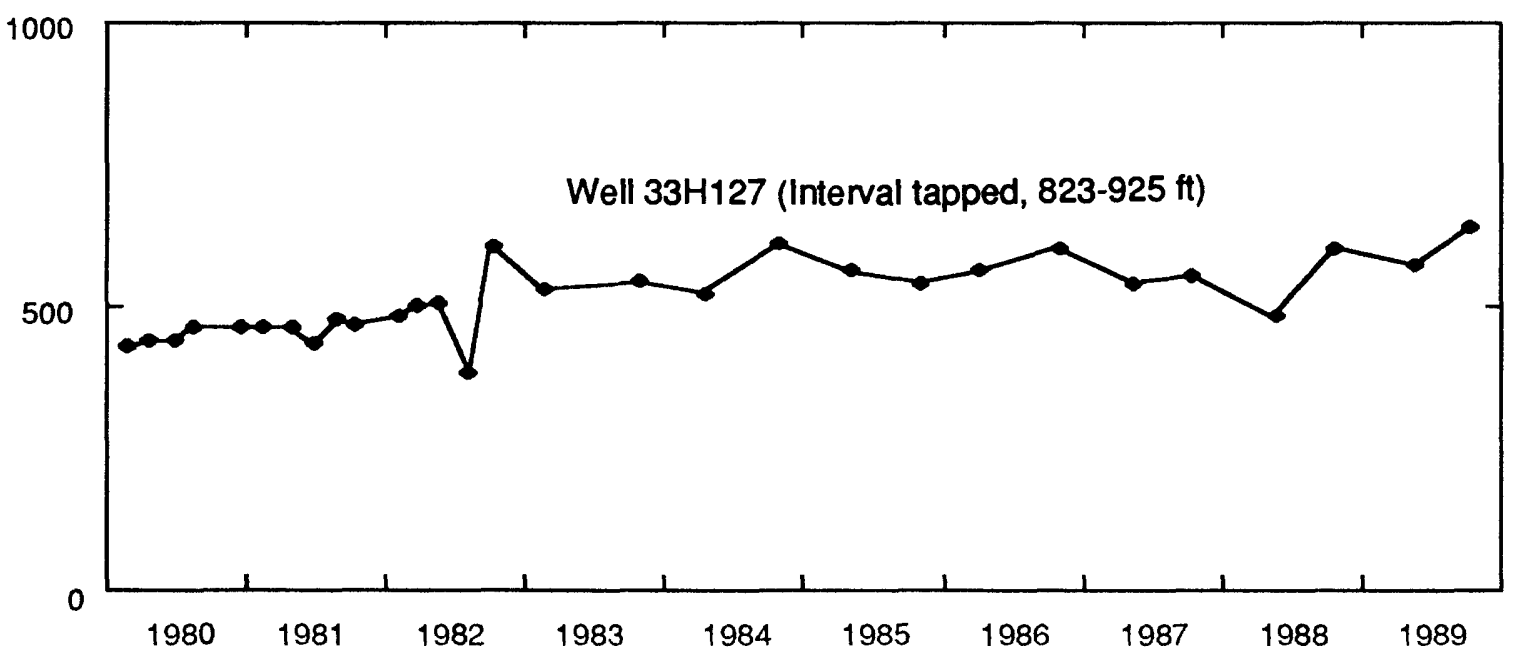

LOWER-WATER BEARING ZONE OF THE UPPER FLORIDAN AQUIFER

Figure 106.--Chloride concentrations in the Floridan aquifer system in the north Brunswick area. 
In the Bay Street area of Brunswick, the chloride concentrations in water from the upper and lower water-bearing zones of the Upper Floridan aquifer decreased slightly during 1980-89 (fig. 105). The chloride concentration in water from well 34H393, which taps the upper water-bearing zone were between 2,200 and 2,570 mg/L during 1980-89. From February 1980 to October 1989, the chloride concentration in water from the well had decreased $170 \mathrm{mg} / \mathrm{L}$. Well 34H403, which taps the lower water-bearing zone, yielded water that had chloride concentrations between 1,400 and 1,675 mg/L during 1980-89. From February 1980 to October 1989, the chloride concentration in water from this well decreased $265 \mathrm{mg} / \mathrm{L}$.

In the Bay Street area, chloride concentrations in water from the brackish-water zone in the upper part of the Lower Floridan aquifer increased during 1980-89 (fig. 105). Water from well 34H391, which taps the brackish-water zone, had a chloride concentration of $2,700 \mathrm{mg} / \mathrm{L}$ in October 1989 , which was $100 \mathrm{mg} / \mathrm{L}$ greater than that measured in 1988 and $200 \mathrm{mg} / \mathrm{L}$ greater than that measured in 1980 . Well $34 \mathrm{H} 399$, in the south Brunswick area also taps the brackish-water zone. Water in this well had a chloride concentration of 7,500 $\mathrm{mg} / \mathrm{L}$ at the end of 1989 , which was $400 \mathrm{mg} / \mathrm{L}$ greater than that measured in 1988 , and $925 \mathrm{mg} / \mathrm{L}$ greater than that measured in 1980.

The chloride concentration in the upper water-bearing zone in the north Brunswick area decreased in two of the three wells included in this report during 1980-89 (wells $34 \mathrm{H} 132$ and $34 \mathrm{H} 427$, fig. 106). In well 34H132, the concentration decreased from $1,680 \mathrm{mg} / \mathrm{L}$ in February 1980 to $1,500 \mathrm{mg} / \mathrm{L}$ in October 1989. The concentration in water from well $34 \mathrm{H} 427$ decreased from $1,780 \mathrm{mg} / \mathrm{L}$ in February 1980 to $1,100 \mathrm{mg} / \mathrm{L}$ in October 1989. In water from well 33H133, also tapping the upper water-bearing zone in the north Brunswick area, the chloride concentration generally increased during 1980-89. In February 1980, the concentration in water from this well was $804 \mathrm{mg} / \mathrm{L}$ and in October 1989 the concentration was $1,600 \mathrm{mg} / \mathrm{L}$, an increase of 796 $\mathrm{mg} / \mathrm{L}$.

In the lower water-bearing zone in the north Brunswick area, the chloride concentration in water from well $33 \mathrm{H} 127$ increased during 1980-89 (fig. 106). The concentration was $428 \mathrm{mg} / \mathrm{L}$ in February 1980 , and 640 $\mathrm{mg} / \mathrm{L}$ in October 1989, an increase of $212 \mathrm{mg} / \mathrm{L}$. Chloride concentrations in the well increased $40 \mathrm{mg} / \mathrm{L}$ during 1988-89. 


\section{SELECTED REFERENCES}

Arora, Ram, ed., 1984, Hydrogeologic evaluation for underground injection control in the Coastal Plain of Georgia: Georgia Geologic Survey, Hydrologic Atlas 10, 45 p.

Brooks, Rebekah, Clarke, J.S., and Faye, R.E., 1985, Hydrogeology of the Gordon aquifer system of eastcentral Georgia: Georgia Geologic Survey Information Circular 75, 41 p.

Carter, R.F., and Stiles, H.R., 1983, Average annual rainfall and runoff in Georgia, 1941-70: Georgia Geologic Survey Hydrologic Atlas 9, 1 sheet.

Clarke, J.S., 1987, Potentiometric surface of the Upper Floridan aquifer in Georgia, May 1985, and water-level trends, 1980-85: Georgia Geologic Survey Hydrologic Atlas 16, 1 sheet, scale 1:1,000,000.

Clarke, J.S., Brooks, Rebekah, and Faye, R.E., 1985, Hydrogeology of the Dublin and Midville aquifer system of east-central Georgia: Georgia Geologic Survey Information Circular 74, 62 p.

Clarke, J.S., Faye, R.E., and Brooks, Rebekah, 1983, Hydrogeology of the Providence aquifer of southwest Georgia: Georgia Geologic Survey Hydrologic Atlas 11, 5 sheets.

---- 1984, Hydrogeology of the Clayton aquifer of southwest Georgia: Georgia Geologic Survey Hydrologic Atlas 13, 6 sheets.

Clarke, J.S., Hacke, C.M., and Peck, M.F., 1990, Geology and ground-water resources of the coastal area of Georgia: Georgia Geologic Survey Bulletin 113, 106 p.

Clarke, J.S., Joiner, C.N., Longsworth, S.A., McFadden, K.W., and Peck, M.F., 1986, Ground-water data for Georgia, 1985: U.S. Geological Survey Open-File Report 86-304, 159 p.

Clarke, J.S., and McConnell, J.B., 1987, Georgia ground-water quality: U.S. Geological Survey Open-File Report 87-0720, 9 p.

Clarke, J.S., and Pierce, R.R., 1984, Ground-water resources of Georgia: Georgia Operator, v. 21, no. 4, p. 1039.

Cressler, C.W., Thurmond, C.J., and Hester, W.G., 1983, Ground water in the Greater Atlanta Region, Georgia: Georgia Geologic Information Circular 63, 144 p.

Georgia Department of Natural Resources, 1977, Rules for safe drinking water: Atlanta, Environmental Protection Division, Chapter 391-3-5, p. 601-657.

Gill, H.E., and Mitchell, G.D., 1979, Results of Colonels Island deep hydrologic test well, in Investigations of alternative sources of ground water in the coastal area of Georgia: Georgia Department of Natural Resources, Geologic and Water Resources Division Open-File Report 80-3, p. C1-C13.

Hayes, R.H., Maslia, M.L., and Meeks, W.C., 1983, Hydrology and model evaluation of the principal artesian aquifer, Dougherty Plain, southwest Georgia: Georgia Geologic Survey Bulletin 97, 93 p.

Hicks, D.W., Krause, R.E., and Clarke, J.S., 1981, Geohydrology of the Albany area, Georgia: Georgia Geologic Survey Information Circular 57, 31 p.

Hicks, D.W., Gill, H.E., and Longsworth, S.A., 1987, Hydrogeology, chemical quality, and availability of ground water in the Upper Floridan aquifer, Albany area: U.S. Geological Survey Water-Resources Investigations Report 87-4149, 52 p. 


\section{SELECTED REFERENCES--Continued}

Joiner, C.N., Peck, M.F., Reynolds, M.S., and Stayton, W.L., 1989, Ground-water Data for Georgia, 1988: U.S. Geological Survey Open-File Report 89-408, 176 p.

Krause, R.E., 1979, Geohydrology of Brooks, Lowndes, and western Echols Counties, Georgia: U.S. Geological Survey Water-Resources Investigations Report 78-117, 48 p.

Krause, R.E., Matthews, S.E., and Gill, H.E., 1984, Evaluation of the ground-water resources of coastal Georgia--Preliminary report on the data available as of July 1983: Georgia Geologic Survey Information Circular 62, $55 \mathrm{p}$.

Krause, R.E., and Randolph, R.B., 1989, Hydrology of the Floridan aquifer system in southwest Georgia and adjacent parts of Florida and South Carolina: U.S. Geological Survey Professional Paper 1403-D, D1-D65.

Marella, R., 1986, Annual water use survey: 1985: St. Johns River Water Management District, Technical Publication SJ 86-5, August 1986, 117 p.

McFadden, S.S., and Perriello, P.D., 1983, Hydrogeology of the Clayton and Claiborne aquifers in southwestern Georgia: Georgia Geologic Survey Information Circular 55, 59 p.

Miller, J.A., 1986, Hydrogeologic framework of the Floridan aquifer system in Florida and in parts of Georgia, South Carolina, and Alabama: U.S. Geological Survey Professional Paper 1403-B, 91 p.

Pierce, R.R., and Kundel, J.E., 1990, Georgia water supply and use; in Carr, J.E., Chase, E.B., Paulson, R.W., and Moody, D.W., ed.; National water summary 1987-hydrologic events and water supply and use: U.S. Geological Survey Water-Supply Paper 2350, p. 215-222.

Stiles, H.R., and Matthews, S.E., 1983, Ground-water data for Georgia, 1982: U.S. Geological Survey OpenFile Report 83-678, 147 p.

Trent, V.P., Fanning, J.L., and Doonan, G.A., 1990, Water use in Georgia by county for 1987: Georgia Geologic Survey Information Circular 85, $112 \mathrm{p}$.

U.S. Environmental Protection Agency, 1986a, Maximum contaminant levels (subpart B of part 141, National interim primary drinking-water standards): U.S. Code of Federal Regulations, Title 40, Parts 100 to 149 , revised July 1, 1986, p. 524-528.

---- 1986b, Secondary maximum contaminant levels (section 143.3 of part 143, National secondary drinkingwater regulations): U.S. Code of Federal Regulations, Title 40, Parts 100 to 149, revised July 1, 1986, p. $587-590$. 